\title{
Data Summary Report for the Annual Fourmile Branch and F- and H-Area Seeplines, Appendix IX Metals and Radionuclides, 1998
}

by

J. Koch

Westinghouse Savannah River Company

Savannah River Site

Aiken, South Carolina 29808

This paper was prepared in connection with work done under the above contract number with the U.S. Department of Energy. By acceptance of this paper, the publisher and/or recipient acknowledges the U.S. Government's right to retain a nonexclusive, royalty-free license in and to any copyright covering this paper, along with the right to reproduce and to authorize others to reproduce all or part of the copyrighted paper. 


\title{
Data Summary Report for the Annual Fourmile Branch and F- and H-Area Seeplines, Appendix IX Metals and Radionuclides, 1998
}

(U)

\author{
Prepared by: \\ Environmental Protection Department \\ Environmental Geochemistry Group \\ Westinghouse Savannah River Company \\ Aiken, SC \\ and \\ Exploration Resources, Inc. \\ Athens, GA
}

September 11, 1998

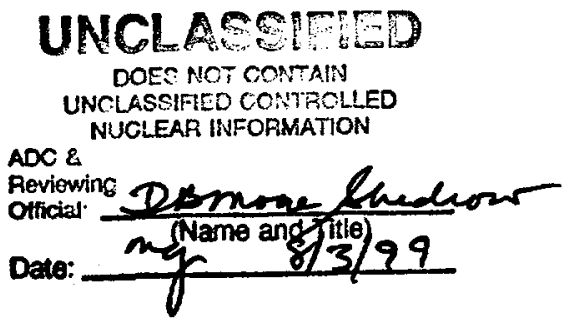




\section{DISCLAIMER}

This report was prepared as an account of work sponsored by an agency of the United States Government. Neither the United States Government nor any agency thereof, nor any of their employees, makes any warranty, express or implied, or assumes any legal liability or responsibility for the accuracy, completeness, or usefulness of any information, apparatus, product, or process disclosed, or represents that its use would not infringe privately owned rights. Reference herein to any specific commercial product, process, or service by trade name, trademark, manufacturer, or otherwise does not necessarily constitute or imply its endorsement, recommendation, or favoring by the United States Government or any agency thereof. The views and opinions of authors expressed herein do not necessarily state or reflect those of the United States Government or any agency thereof.

This report has been reproduced directly from the best available copy.

Available to DOE and DOE contractors from the Office of Scientific and Technical Information, P.O. Box 62, Oak Ridge, TN 37831; prices available from (615) 576-8401.

Available to the public from the National Technical Information Service, U.S. Department of Commerce, 5285 Port Royal Road, Springfield, VA 22161. 


\section{DISCLAIMER}

Portions of this document may be illegible in electronic image products. Images are produced from the best available original document. 
List of Tables

List of Acronyms and Abbreviations ................................................................................ vii

Figure

Figure 1. Sampling Locations for Fourmile Branch and the F- and H-Area Seeplines........................................................................

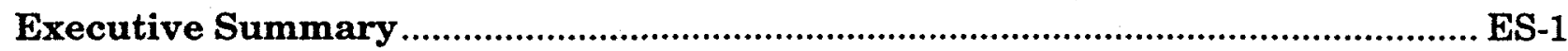

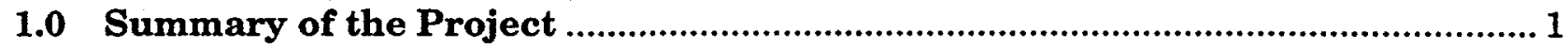

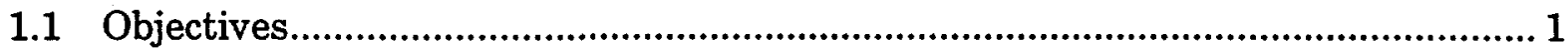

1.2 Overview

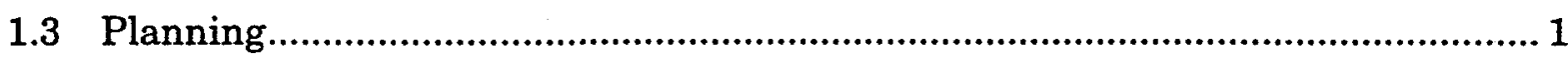

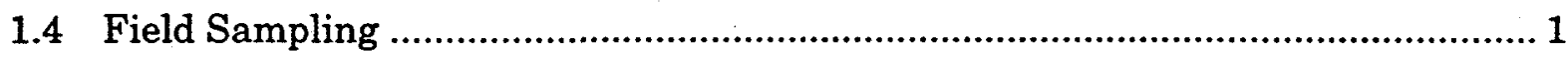

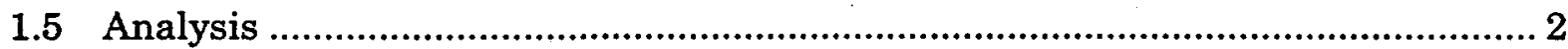

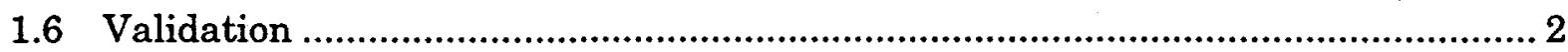

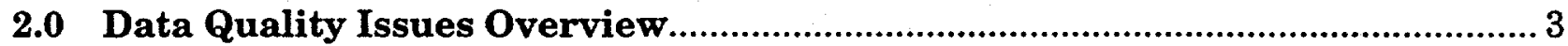

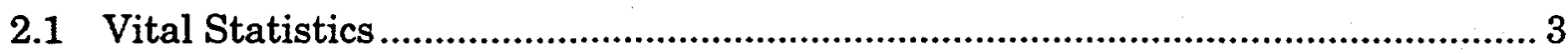

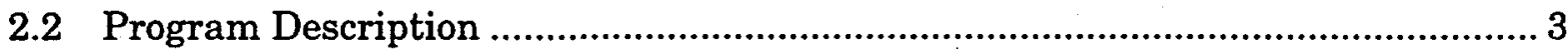

2.2.1 Verification and Validation Objectives........................................................ 3

2.2.2 Verification and Validation Functions ...................................................... 4

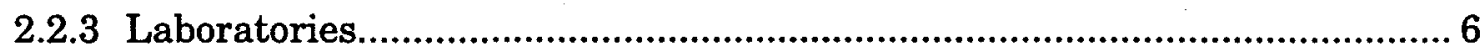

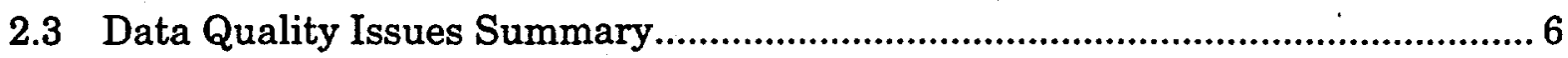

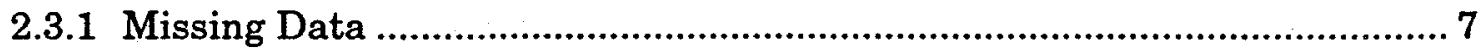

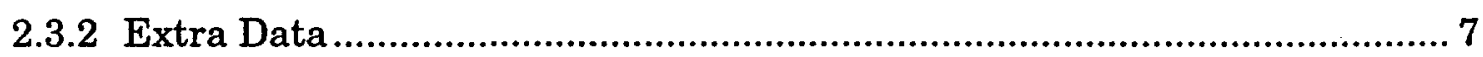

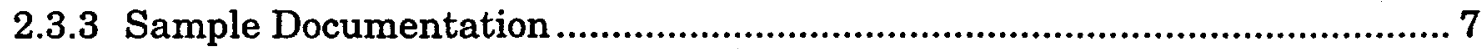

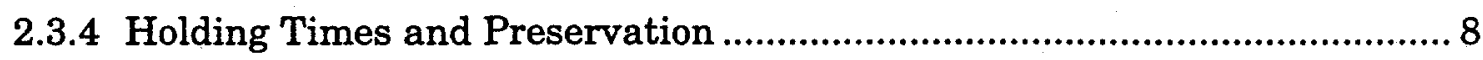

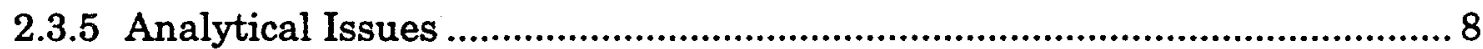

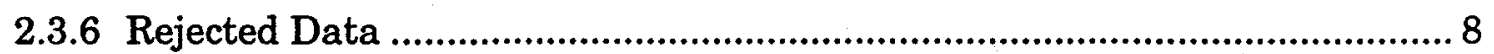




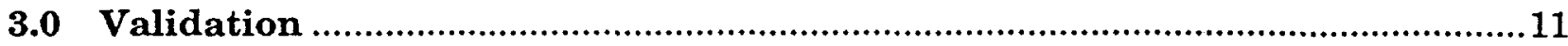

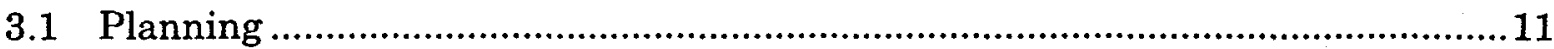

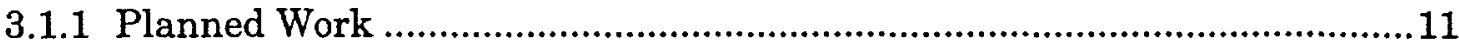

3.1.2 Production of Chain-of-Custody Forms ................................................11

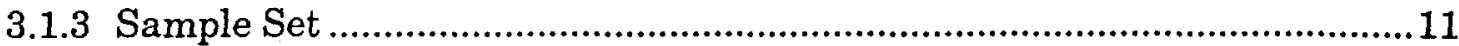

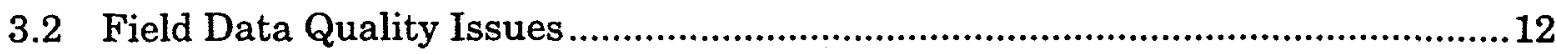

3.2.1 Discrepancies from the Planned Work .............................................12

3.2.2 Sample Logbook Observations ........................................................ 13

3.2.3 Chain-of-Custody Observations.........................................................13

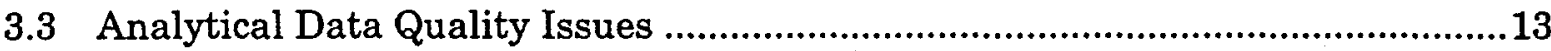

3.3.1 The Laboratories .......................................................................... 13

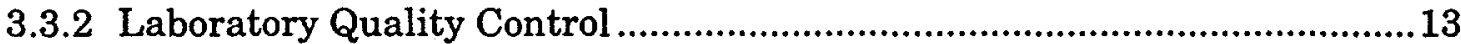

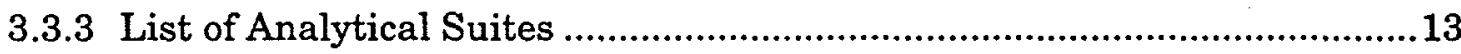

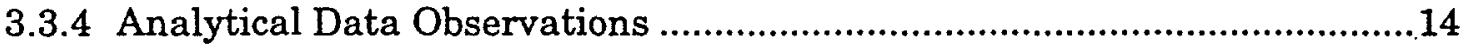

3.4 Verification and Validation Issues ............................................................14

3.4.1 Analytical Narrative Review .......................................................... 14

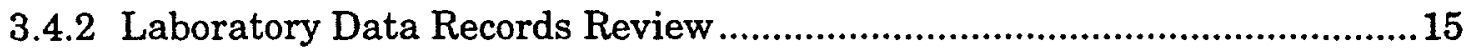

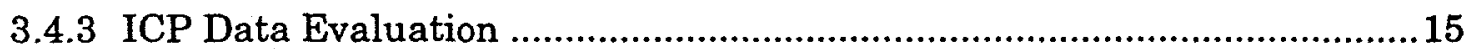

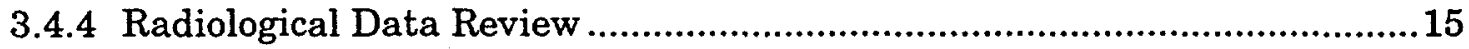

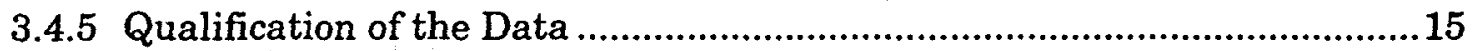

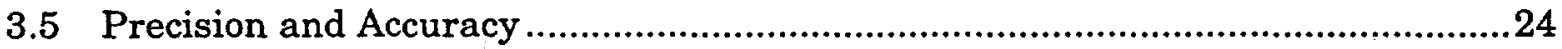

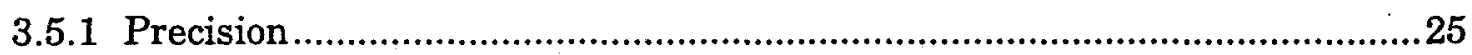

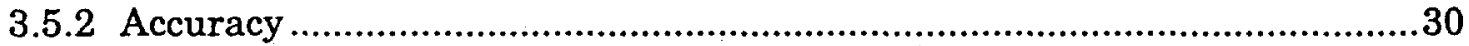

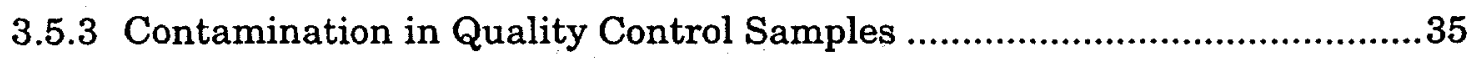

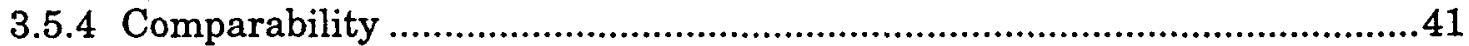

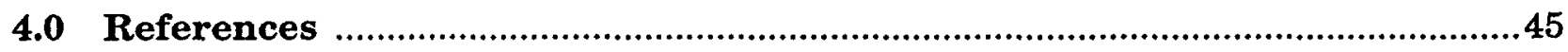

Appendix A: Analytical Methods and Method Detection Limits........................ A-1

Appendix B: Laboratory Performance Evaluation Results ............................... B-1

B.1 EPA Performance Evaluation Study Results............................................. B-1 
B.2 EMS Quality Control Standards Results

B-2

B.3 Mixed Analyte Performance Evaluation Program

B.4 EPA Radiological Performance Evaluation Studies B-3

Appendix C: Formats of the Data Files. C-1

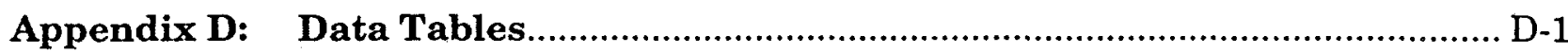

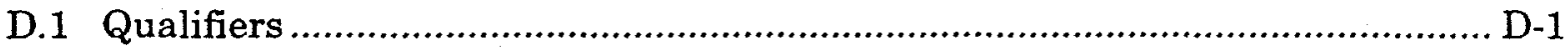

D.2 Data Summaries............................................................................... D-3

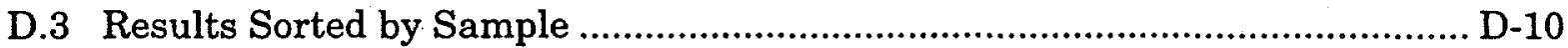

D.4 Results Sorted by Analyte ................................................................... D-45

Appendix E: Data Management/Administrative Files ..................................E-1

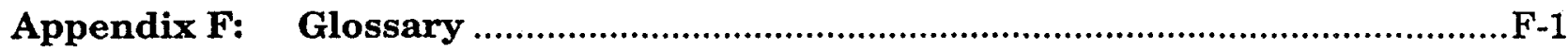




\section{List of Tables}

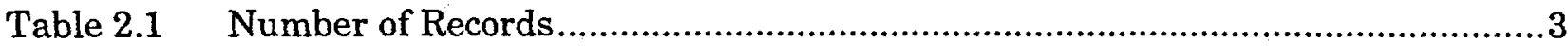

Table 2.2 Number of Soil Records Qualified as Rejected, Estimated, or Not

Detected ..............................................................................................................

Table 2.3 Chain-of-Custody Documentation Summary .....................................................

Table 2.4 Holding Time Exceedances ...............................................................................

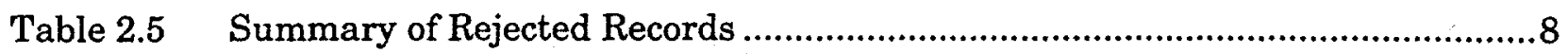

Table 2.6 Environmental Sample Analytical Records Rejected...........................................9

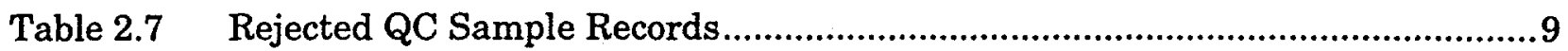

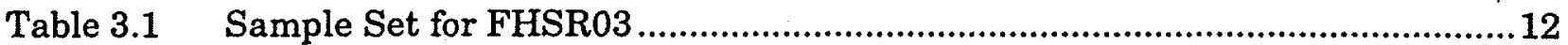

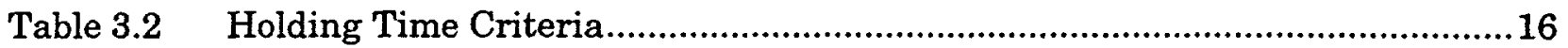

Table 3.3 Holding Times Exceeded by GE..................................................................

Table 3.4 Holding Times Exceeded by Recra ..................................................................17

Table 3.5 Method Blank Contamination by GE .......................................................19

Table 3.6 Method Blank Contamination by Recra ...........................................................20

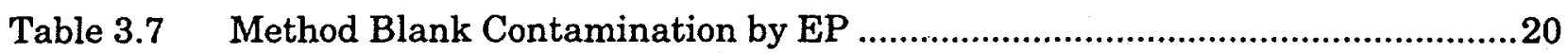

Table 3.8 Laboratory Control Samples and Blank Spikes Outside Ranges for EP .........21

Table 3.9 Laboratory Control Samples and Blank Spikes Outside Ranges forTNU .......21

Table 3.10 Laboratory Duplicate Results Outside RPD Limits by TNU.............................23

Table 3.11 Matrix Spike Recoveries Outside the EPA Recovery Limits by GE.................24

Table 3.12 Matrix Spikes With Sample Concentrations Four Times Higher Than Nominal Concentration for Samples by GE....................................................24

Table 3.13 Relative Percent Differences of Laboratory Duplicates by GE.........................25

Table 3.14 Relative Percent Differences of Laboratory Duplicates by Recra......................26

Table 3.15 Relative Percent Differences of Laboratory Duplicates by EP .........................26

Table 3.16 Relative Percent Differences of Laboratory Duplicates by TNU ......................27

Table 3.17 Relative Percent Differences of Field Duplicates by GE ..................................28

Table 3.18 Relative Percent Differences of Field Duplicates by EP ....................................29

Table 3.19 Laboratory Control Samples and Blank Spike Recoveries by GE....................31

iv Data Summary Report for the Annual Fourmile Branch and F- and H-Area Seeplines, Appendix IX Metals and Radionuclides, 1998

(WSRC-TR-98-00260) 
Table 3.20 Laboratory Control Samples and Blank Spike Recoveries by Recra 32

Table 3.21 Laboratory Control Samples and Blank Spike Recoveries by EP. 33

Table 3.22 Laboratory Control Samples and Blank Spike Recoveries by TNU .... 33

Table 3.23 Matrix Spike Recoveries by GE 34

Table 3.24 Matrix Spike Recoveries by Recra 35

Table 3.25 Matrix Spike Recoveries by EP. 35

Table 3.26 Analytes Detected in Field Blanks by GE . 36

Table 3.27

Analytes Detected in Field Blanks by EP. 37

Table 3.28

Analytes Detected in Method Blanks by GE . 38

Table 3.29

Analytes Detected in Method Blanks by Recra . 39

Table 3.30

Analytes Detected in Method Blanks by EP... 39

Table 3.31

Analytes Detected in Method Blanks by TNU 41

Table 3.32

Split Sample Results for GE and Recra. 42

Table A.1 Water Analytical Methods and Detection Limits for GE... A-1

Table A.2 Water Analytical Methods and Detection Limits for Recra..... A-2

Table A.3

Water Analytical Methods and Minimum Detectable Activities for EP. A-3

Table A.4 Water Analytical Methods and Minimum Detectable Activities for TNU......A-4

Table B.1 Mixed Analyte Performance Evaluation Program Results for MAPEP96-S3 for EP and TNU B-3

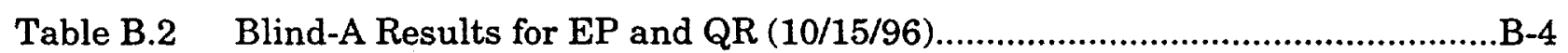

Table B.3 Blind-B Results for EP and QR (10/15/96) .................................................4

Table B.4 Gamma in Water Results for EP and QR (11/8/96) ....................................4

Table B.5 Strontium in Water Results for EP and QR (1/17/97) ...................................4

Table B.6 Gross Alpha-Beta in Water Results for EP and QR (1/31/97)....................B-5

Table B.7 Uranium-Radium in Water Results for EP and QR (2/14/97)..................... B-5

Table C.1 Sample Data Format SAM93 ...............................................................

Table C.2 Sample Bottle Data Format SAM93A...........................................................

Table C.3 Survey Station Data Format STA93 ..........................................................

Table C.4 Chain-of-Custody Data Format COC93 ......................................................

Table C.5 Analytical Data Format AN95 …....................................................

Data Summary Report for the Annual Fourmile Branch and

F- and H-Area Seeplines, Appendix IX Metals and Radionuclides, 1998

(WSRC-TR-98-00260) 
Table C.6 Analytical Data Format AN95-R2.B................................................... C-7

Table C.7 Codes for Laboratory Replicates.......................................................... C-8

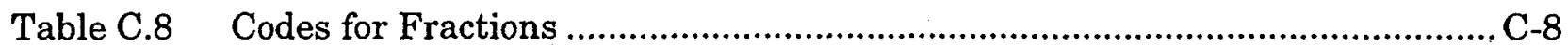

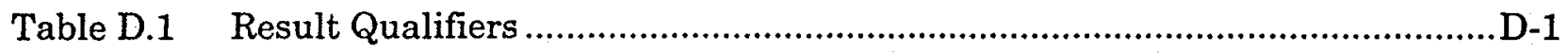

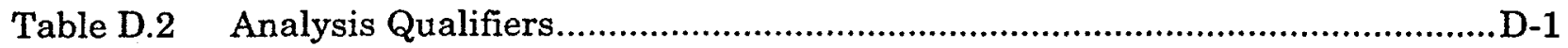

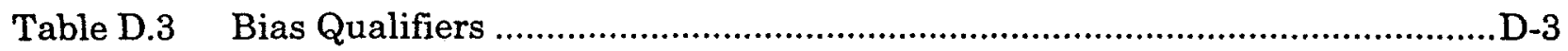

Table D.4 Number of Analytical Records by Method and Type of Record ....................D-4

Table D.5 Analytes Not Detected in Background Water Samples ................................D-5

Table D.6 Analytes Detected in Background Water Samples ..................................D-7

Table D.7 Analytes Not Detected in Routine Water Samples.....................................D-8

Table D.8 Analytes Detected in Routine Water Samples ......................................... D-9

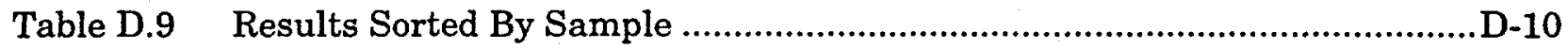

Table D.10 Blank Results Sorted by Sample ....................................................... D-42

Table D.11 Sample Results Sorted by Analyte ....................................................... D-45

Table D.12 Blank Results Sorted by Analyte................................................. D-78 


\section{List of Acronyms and Abbreviations}

The following acronyms and abbreviations may appear in this Data Summary Report:

${ }^{\circ} \mathrm{C}$

$\mu \mathrm{g}$

$\mu \mathrm{L}$

$\mu \mathrm{S}$

AA

$\mathrm{AQ}$

ASTM

BAT

bls

BNA

B

CCB

$\mathrm{CCV}$

CERCLA

CFR

CLP

$\mathrm{cm}$

$\mathrm{COC}$

CPT

CRDL

CRQL

CSDL

CV

CVAA

DI degrees Celsius

microgram(s)

microliter

microSiemens

atomic absorption

analysis qualifier

American Society for Testing and Materials

BAT Associates, Inc.

below land surface

base/neutral/acid extractables

bias qualifier

continuing calibration blank sample

continuing calibration verification sample

Comprehensive Environmental Response, Compensation, and Liability Act (Superfund)

Code of Federal Regulations

Contract Laboratory Program

centimeter(s)

chain of custody; chain-of-custody form

cone penetrometer test

contract-required detection limit

contract-required quantitation limit

contract-specified detection limit

coefficient of variation

cold vapor atomic absorption analysis

deionized (water) 
DOE

United States Department of Energy

dpm

disintegrations per minute

DPT

direct push technology

DQOs

data quality objectives

EAS

Environmental Analysis Section

EDD

electronic data deliverable

EGG

Environmental Geochemistry Group

Eh

oxidation-reduction potential

EM-PPM

parts per million methane equivalent

EMSL

EPA's Environmental Monitoring and Support Laboratory

EP

Environmental Physics, Inc.

EPA

United States Environmental Protection Agency

EPD/EMS

Environmental Protection Department/Environmental Monitoring Section

EQL

estimated quantitation limit (for non-radiochemistry analyses)

ERA

Environmental Resource Associates

ERD

Environmental Restoration Department

ESC

expedited site characterization

ES\&T

Environmental Sciences and Technology Department, formerly known as ESS (Environmental Sciences Section)

ExR

Exploration Resources, Inc.

FID

flame ionization detector

$\mathrm{ft}$

feet

g

$\operatorname{gram}(\mathrm{s})$

FHSR

Fourmile Branch and F- and H-Area Seeplines

GC

gas chromatography

GC/MS

gas chromatography/mass spectrometry

GE

General Engineering Laboratories, Inc.

GFAA

graphite furnace atomic absorption (metals analysis) 


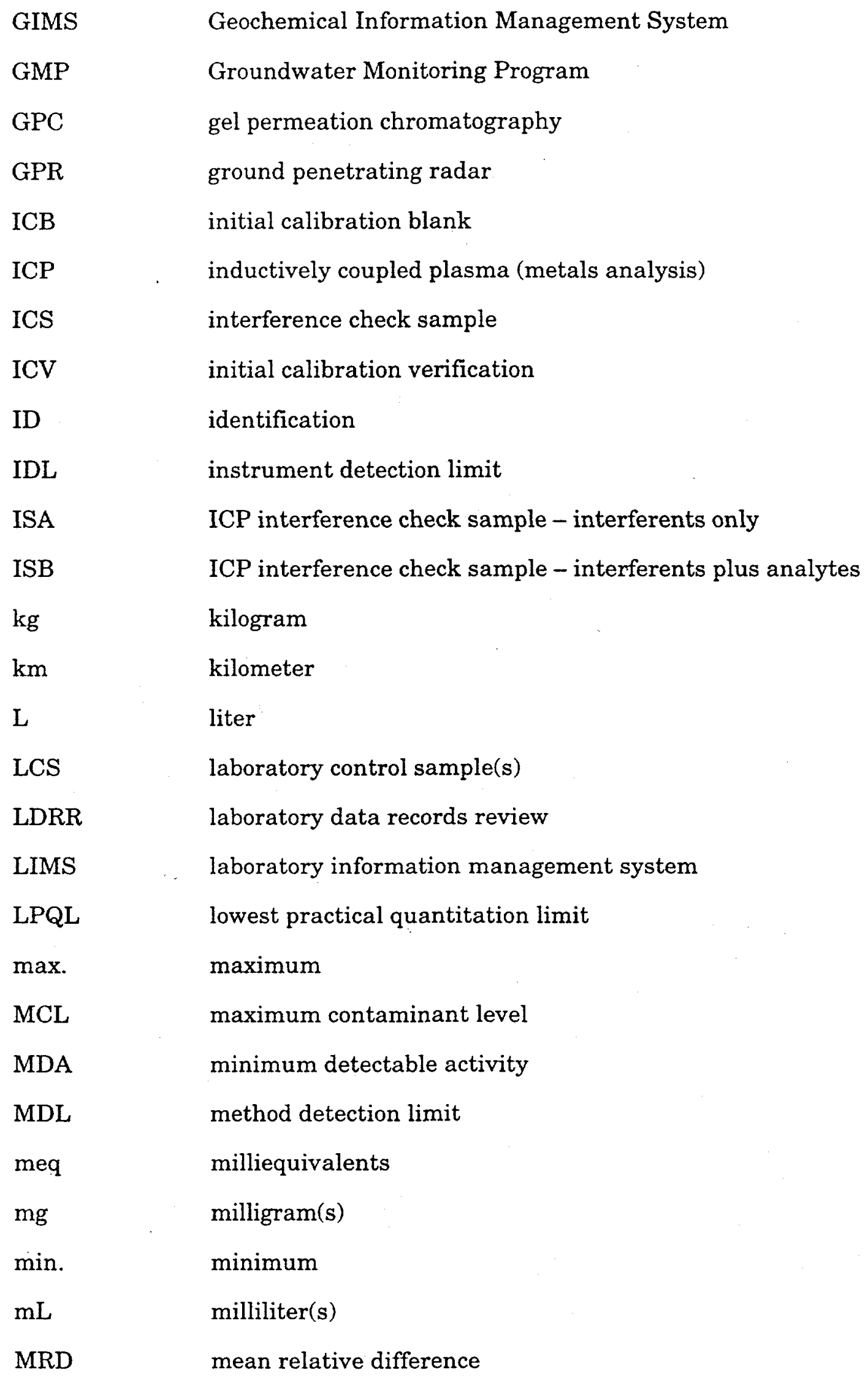


MS

MSA

MSD

MSL

NA

NAPL

ng

NIST

NTU

OVA

PAH

PAL

PCB

$\mathrm{pCi}$

PE

PHA

PID

$\mathrm{ppb}$

ppm

QA/QC

$\mathbf{r}$

RCO

RCRA

Recra

RFI/RI

RPD

RQ matrix spike

method of standard addition

matrix spike duplicate

mean sea level

not applicable

non-aqueous phase liquid

nanogram(s)

National Institute of Standards and Technology

nephelometric turbidity unit

organic vapor analyzer

polynuclear aromatic hydrocarbons

performance acceptance limit

polychlorinated biphenyl

picoCurie

performance evaluation

pulse-height analysis; e.g., gamma PHA

photoionization detector

parts per billion

parts per million

quality assurance/quality control

correlation coefficient

Radiological Control Officer

Resource Conservation and Recovery Act

Recra LabNet Philadelphia (formerly Roy F. Weston, Inc., Analytics Division)

RCRA Facility Investigation/Remedial Investigation

relative percent difference

result qualifier 
RRT

RSD

RTW

SAIC

SCDHEC

SGS

SMC

SOP

SOW

SQL

SRS

SRTC

SSC

ssEQL

std. dev.

SW-846

TAL

TCL

TCLP

TIC

TNU

$\mathrm{U}$

USEPA

UTM

VOA

VOC

WHC

WSRC relative retention time

relative standard deviation

retention time window

Science Applications International Corporation

South Carolina Department of Health and Environmental Control

Site Geotechnical Services

sample/method combination

standard operating procedure

statement of work

sample quantitation limit

Savannah River Site

Savannah River Technology Center

site-specific contaminant

sample-specific estimated quantitation limit

standard deviation

EPA's Test Methods for Evaluating Solid Waste

target analyte list

target compound list

toxicity characteristic leaching procedure

tentatively identified compound

Thermo NUtech

unclassified

see EPA

Universal Transverse Mercator Zone 17 Coordinate System

volatile organic analyses

volatile organic compound

Westinghouse Hanford Company

Westinghouse Savannah River Company 


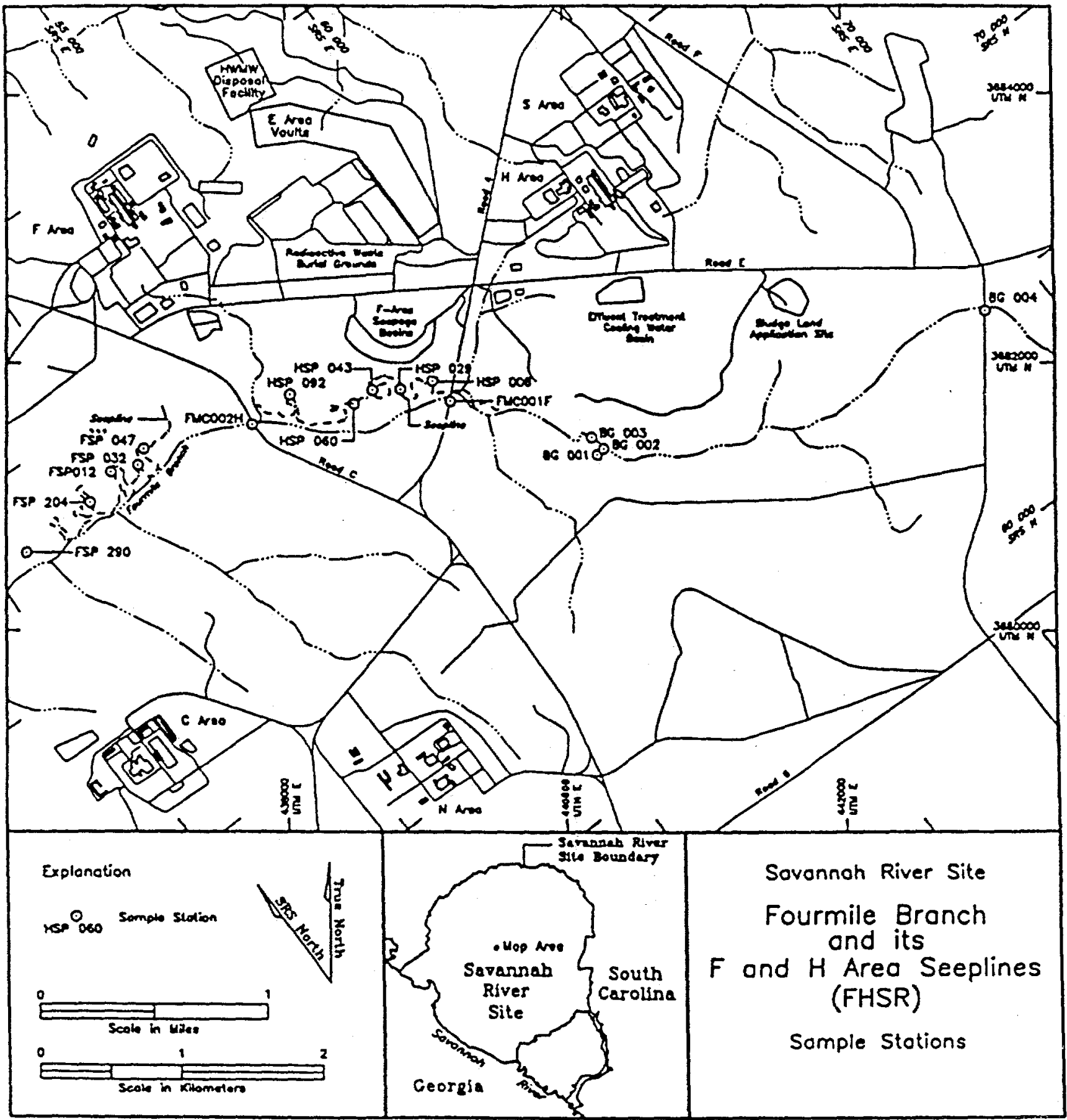

Figure 1. Sampling Locations for Fourmile Branch and the F- and H-Area Seeplines

xii Data Summary Report for the Annual Fourmile Branch and F- and H-Area Seeplines, Appendix IX Metals and Radionuclides, 1998 


\section{Executive Summary}

\section{Purpose}

This report presents a summary of the definitive data validation and verification for the $1998 \mathrm{RFI}^{\mathrm{RI}}{ }^{1}$ annual Appendix IX metals and radionuclides survey for Fourmile Branch and the F- and H-Area Seeplines. The RFI/RI was performed under the direction of the WSRC Environmental Sciences and Technology Department/Ecology. This report was prepared under the direction of EPD/EMS.

\section{Scope of the Project}

ExR of Athens, GA, validated and verified sample collection, shipping, and laboratory information compiled for this project. The information compiled, reviewed, and maintained includes the following:

- sample documentation

- $\mathrm{COC}$ forms

- sample holding times

- initial and continuing instrument calibration

- analyte identification

- analyte quantitation

- analytical error

- analysis of blanks

- laboratory performance evaluations

- quantitation limits

The validation process began with project mobilization and continued through the delivery of EDDs and this report.

1 All acronyms and abbreviations used in this report are defined in the List of Acronyms and Abbreviations (pp. vii-xi). 


\section{Process and Documentation}

Sample documentation and maintenance of COC were examined by reviewing the field logs and COC forms. See section 3.1.2, Production of Chain-of-Custody Forms, of this report for more information about the COC forms.

Sample holding times were checked by comparing the time between sample collection and analysis with a look-up table of maximum holding times. Analytical instrument calibration was reviewed as part of the LDRR. See section 3.4.2, Laboratory Data Records Review, of this report for more information about the LDRR.

Analyte identification and analyte quantitation were verified as part of the computerized checking of the EDDs, during review of the analytical narratives, and as part of the LDRR. Anomalies were clarified with the laboratories wherever possible, and records not meeting criteria were qualified. See section 3.4, Verification and Validation Issues, of this report for further information.

In evaluating analytical error, percent recoveries for $\mathrm{QC}$ samples were reviewed, and the QC sample and associated project sample data were qualified where necessary. Relative percent differences between duplicate sample analyses were calculated. The criteria for qualification are described in section 3.4.5, Qualification of the Data, of this report.

Field-generated blanks (i.e., field blanks, rinsate blanks, and trip blanks) and laboratorygenerated blanks (i.e., method blanks) were examined if included in the sampling plan. See section 3.1, Planning, of this report for an overview of the sampling plan. Laboratorygenerated blanks were analyzed in ratios of more than one for every 20 samples.

Laboratory performance evaluations are detailed in Appendix $B$ of this report.

\section{Annual Appendix IX Metals and Radionuclides Survey for Fourmile Branch and the F- and H-Area Seeplines Affiliates}

The project was completed by the following people and/or organizations:

- Jim Koch, WSRC-ES\&T/EAS, Aiken, SC, was the project manager.

- C. Dan Rogers, WSRC-EPD/EMS, Aiken, SC, was the project technical lead.

- Jim Koch, WSRC-ES\&T/EAS, Aiken, SC, collected the water samples.

- $\mathrm{GE}$ of Charleston, $\mathrm{SC}$, and Recra of Lionville, PA, prepared the definitive-level analytical data.

- ExR of Athens, GA, validated the data and prepared this report.

Data Summary Report for the Annual Fourmile Branch and

F- and H-Area Seeplines, Appendix IX Metals and Radionuclides, 1998

(WSRC-TR-98-00260) 


\subsection{Summary of the Project}

\subsection{Objective}

The objective of this project is to provide validated data for the 1998 annual Appendix IX metals and radionuclides sampling event in Fourmile Branch and the F- and $\mathrm{H}$-Area Seeplines.

\subsection{Overview}

Seepage basins in the $\mathrm{F}$ and $\mathrm{H}$ Areas received low-level radioactive waste effluent from the chemical separation processes in the General Separations Area. The basins retained the effluent to delay its release to the environment. The waste effluent consisted principally of sodium hydroxide, nitric acid, low levels of various radionuclides, and some metals. Discharges of tritiated water to the seepage basins account for most of the radioactivity.

In 1988 and 1989, the Savannah River Laboratory (now the Savannah River Technology Center) conducted an extensive study aimed at characterizing the shallow groundwater outcropping into Fourmile Branch and its associated seeplines. Researchers measured low $\mathrm{pH}$ values, elevated conductivity, and tritium along the seeplines and determined that contaminants leaching from the F- and H-Area seepage basins were impacting the area.

Discharges to the seepage basins were stopped in 1988 , and the basins were capped and sealed in 1990 to minimize the release of contaminants to the environment. Scientists hypothesized that after eliminating the contaminant source, annual rainfall amounts and natural groundwater flow would, over time, dilute and flush the remaining contaminant plume out of the shallow groundwater, which would allow recovery of the wetland systems below the basins.

\subsection{Planning}

Twenty-three samples were to be collected, including 17 seepline water samples, two duplicate samples, two split samples, and two field blanks. Concurrent with the sample collection, $\mathrm{pH}$, specific conductance, and water temperatures were to be measured in the field and recorded in the sample logbooks.

\subsection{Field Sampling}

Sampling took place on April 13-16 and April 21, 1998. Twenty-three samples, duplicates, and splits were collected. Of those collected, 17 were seepline water samples, two were field blanks, two were duplicate samples, and two were split samples. 


\subsection{Analysis}

Seepline water samples, duplicates, and splits were analyzed for the following constituents: Appendix IX tin, chloride, gamma PHA, gross alpha, nitrate, nitrate/nitrite, nonvolatile beta, TAL metals (including cyanide), total hardness, and tritium. For any samples that exceeded $15 \mathrm{pCi} / \mathrm{L}$ gross alpha, alpha speciation was required, including alpha spec americium, alpha spec curium, lpha spec neptunium, alpha spec uranium, and radium-226. If nonvolatile beta exceeded $50 \mathrm{pCi} / \mathrm{L}$, beta speciation was required, to include iodine-129, nickel-63, radium-228, strontium-90, and technetium-99. Field blanks were analyzed for Appendix IX tin, gamma PHA, gross alpha, nonvolatile beta, and TAL metals (including cyanide).

\subsection{Validation}

Validation and verification activities, using definitive data requirements (EPA, 1993), assessed the quality of the definitive level data for the following issues:

- sample documentation

- maintenance of chain of custody

- adherence to sample holding time requirements

- achievement of contract-required quantitation limits

- analytical instrument calibration

- analyte identification

- analyte quantitation

Evaluation of each laboratory's performance in analyte identification and quantitation included examination of the following:

- analytical error

- contamination of blanks

- laboratory performance evaluation samples

- quantitation limit determination, if applicable 


\subsection{Data Quality Issues Overview}

This section provides a summary of the major points affecting the quality of the data for this project.

\subsection{Vital Statistics}

Twenty-three COCs were generated and used for this project. Of the 23 samples, seventeen were normal environmental, two were duplicates, two were splits, and two were field blanks.

The total number of records for this project is given in table 2.1.

\section{Table 2.1 Number of Records}

\begin{tabular}{|l|l|l|l|}
\hline Type of Records & Chemical Records & Radiochemical Records & Totals \\
\hline Environmental Sample Records & 659 & 710 & 1,369 \\
\hline QC Records & 564 & 251 & 815 \\
\hline Totals & 1,223 & 961 & 2,184 \\
\hline
\end{tabular}

Table 2.2 lists the number of sample and QC records that were qualified with $R, J, U$, or $U J$ result qualifiers after verification and validation were performed.

Table 2.2 Number of Soil Records Qualified as Rejected, Estimated, or Not Detected

\begin{tabular}{|l|l|l|l|}
\hline Data Validation Records & Sample Records & QC Records & Total \\
\hline Total Number of Analytical Records & 1,369 & 815 & 2,184 \\
\hline Qualified Data & \multicolumn{3}{|l|}{} \\
\hline Rejected Analytical Records & 9 & 3 & 12 \\
\hline Result Qualifier $U$ & 916 & 312 & 1,228 \\
\hline Result Qualifier $J$ & 65 & 39 & 104 \\
\hline Result Qualifier $U J$ & 18 & 4 & 22 \\
\hline
\end{tabular}

\subsection{Program Description}

This section discusses the validation of the data and gives a brief overview of the laboratories.

\subsubsection{Verification and Validation Objectives}

\section{Data Quality Objectives}

Definitive data, as defined in EPA, 1993, have been determined as most appropriate to meet the DQOs of this investigation. Validation and verification activities assessed the data in relation to these standards, especially with regard to the following issues: 
- sample documentation

- maintenance of $\mathrm{COC}$

- adherence to sample holding time and preservation requirements

- achievement of contract-required detection limits

- analytical instrument calibration

- analyte identification

- analyte quantitation

Evaluation of each laboratory's performance for analyte identification and quantitation included examination of analytical error, blank contamination, and laboratory performance in the analysis of independent standards.

Each analytical record in the computer data files contains three qualifier fields: result qualifier, analysis qualifier, and bias qualifier. The result qualifier describes the analytical result. The analysis qualifier describes issues arising during the analytical process. The bias qualifier describes whether the result is biased high or low. The laboratories use these fields in reporting the data. During validation and verification of the analytical data, additional qualifiers may be applied to provide additional information about data quality.

\section{Data Quality Levels}

Definitive-level data are used for data collection activities that require a high degree of qualitative and quantitative accuracy for all findings. Rigorous methods of analysis and quality assurance are used for those samples considered essential in making a decision. This data level is intended to give the decision maker a level of confidence to make decisions regarding the following:

- treatment

- disposal

- site remediation and/or removal of pollutants

- health risk or environmental impact

- cleanup verification, pollutant source identification, delineation of contaminants

- other significant decisions where an action level is of concern

Only analyte-specific methods can be used for definitive-level data. The following analyses do not produce definitive-level data: gross alpha, nitrate-nitrite as nitrogen, nonvolatile beta, $\mathrm{pH}$, phenols, specific conductance, total dissolved solids, total organic carbon, total organic halogens, and total phosphates (as P).

\subsubsection{Verification and Validation Functions}

The data verification process confirms that the required samples were collected and documented, the required analyses were performed on the samples, and the analytical results were reported correctly. The information evaluated during this process includes 
work plan sample lists, work plan analyte/compound lists, field logbooks, COC forms, and analytical results files.

Data reviewers use computer programs and look-up tables to review the computer data files of sample collection, shipping, and analytical data. The data were examined as follows:

- The following fields were checked to ensure that they were not blank: WSRC sample identification number, sample collection date, laboratory receipt date, analysis date, analysis time, analytical method, laboratory code, laboratory sample identification number, analyte code, result units, nominal concentration, number of dilutions, dilution factor, instrument, instrument batch, and analyst's initials.

- The following fields were checked to ensure that the data were within an acceptable range of values: WSRC sample identification number, sample collection date, laboratory receipt date, analysis date, analysis time, analytical result, accuracy, residual weight, number of dilutions, nominal concentration, and bottle number.

- The following fields were checked against a look-up table or a list of valid codes: laboratory code, laboratory duplicate code, analyte code (test name), analytical method, result qualifier, analysis qualifier, analysis bias, result unit, and sample fraction.

The data validation process determines the usefulness of each analytical result based on $\mathrm{QC}$ and method requirements. The information evaluated during this process includes $\mathrm{COC}$ forms, analytical narrative summaries, analytical result data files, and raw result and calibration data.

Data validation involves evaluating requirements in the following $\mathrm{QC}$ categories: holding times, sample preservation, instrument calibration, analyte identification/quantitation, blanks (trip, method, rinsate, and field blanks), laboratory control samples, duplicates (field and laboratory), matrix spikes, surrogates, and internal standards.

Data validation and qualification policies were developed from the following sources: quality control requirements in the analytical methods, data review guidelines provided by the United States Environmental Protection Agency, contract-specific WSRC requirements, and discussions with laboratory personnel.

\section{Data Qualifiers}

When analytical data are validated, the analytical results and the associated QC information are reviewed using criteria specific to the analysis performed. Data qualifiers are used during the data validation process to classify sample data as conforming to QC requirements.

The qualifiers used for data associated with this project are defined in Appendix $D$.

\section{Precision}

Precision measures the reproducibility of measurements under a given set of conditions. It is a quantitative measure of the variability of a group of measurements compared to its average value. Precision is reported in terms of the relative percent difference. The

Data Summary Report for the Annual Fourmile Branch and F- and H-Area Seeplines, Appendix IX Metals and Radionuclides, 1998

(WSRC-TR-98-00260) 
analytical results from the field replicate samples provide data on overall measurement precision; analytical results from the laboratory duplicates provide data on analytical precision. See section 3.5.1.

\section{Accuracy}

Accuracy measures the bias in a measurement system; it is difficult to measure for the entire data collection activity. Sources of error are the sampling process, field contamination, preservation, handling, sample matrix, sample preparation, and sample analysis techniques. Sampling accuracy may be assessed by evaluating the results of rinsates, field blanks, and trip blanks. Analytical accuracy may be assessed through the use of known and unknown QC samples, matrix spikes, and method blanks. See section 3.5.2.

\section{Representativeness}

Representativeness expresses the degree to which sample data accurately and precisely represent a characteristic of a population, parameter variations at a sampling point, or an environmental condition. Representativeness is a qualitative parameter that is most concerned with the proper design of the sampling program and is best satisfied by making certain that sampling locations are selected properly and that a sufficient number of samples are collected.

\section{Completeness}

Completeness is defined as the percentage of measurements made that are judged to be valid measurements. It is important that critical samples are identified and that plans are made to achieve valid data for them. Completeness was not determined for this report.

\section{Comparability}

Comparability is a qualitative parameter expressing the confidence with which one data set can be compared with another. Sample data should be comparable with other measurement data for similar samples and sample conditions. This goal is achieved through using standard techniques to collect and analyze representative samples and through reporting analytical results in appropriate units. See section 3.5.4.

\subsubsection{Laboratories}

The following laboratories generated the analytical data for this project:

- GE of Charleston, SC, the primary laboratory, provided definitive-level inorganic and radiological analyses under contract $A A 07208 \mathrm{~N}$.

- Recra of Lionville, PA, the QC laboratory and a CLP laboratory, provided definitivelevel inorganic and radiological analyses under contract AA07210N.

\subsection{Data Quality Issues Summary}

This section provides a summary of the major data quality issues identified during the verification and validation process. 


\subsubsection{Missing Data}

All planned data for environmental samples were collected and received with the exception of neptunium-239 for split sample stations HSP-060-03-D (sample ID 114013) and FSP032-03-D (sample ID 114022). This data was not reported because an excess of ten half lives had occurred between sample collection and analysis, and therefore, neptunium-239 was no longer present.

\subsubsection{Extra Data}

Alpha speciation analyses were extraneously performed and reported for station FSP-03203 (sample ID 114021).

Combined isotopes uranium-233/234 were reported instead of uranium-234.

Combined isotopes curium-243/244 were reported instead of individual isotopes. Curium$245 / 246$ was reported instead of curium-246.

\subsubsection{Sample Documentation}

All environmental sample COCs were two pages, and both pages for each sample were received from the laboratories. The COCs were also received for both field blanks. The following table details information missing on the COCs. Data quality was not impacted.

Table 2.3 Chain-of-Custody Documentation Summary

\begin{tabular}{|l|c|c|}
\hline Description & Number & Percent \\
\hline Missing transfer dates, times, and signatures & 0 & \\
\hline Missing transfer dates and/or times only & 6 & 26 \\
\hline Missing transfer signatures only & 0 & $7\left({ }_{\text {get }} 9\right)$ \\
\hline Missing cooler number & 2 & \\
\hline Missing temperature & 0 & 74 \\
\hline Missing COCs & 0 & 7 \\
\hline No problems & 17 & \\
\hline Total number of COCs used $=\mathbf{2 3}$ & & \\
\hline
\end{tabular}

Contingent beta speciation analytes technetium-99 and strontium-90 (alpha order) were printed on the COCs, but crossed off on each form and initialed by JWK; no bottles were filled or sent for those analyses.

Two field blanks were associated with this project, however it was not possible to associate either field blank with any environmental samples. The associated sample ID was left blank in the field sample logbook, and the field blanks were recorded with a sample date that did not match any of the normal, duplicate, or split sample collection dates.

Data Summary Report for the Annual Fourmile Branch and

F- and H-Area Seeplines, Appendix IX Metals and Radionuclides, 1998

(WSRC-TR-98-00260) 


\subsubsection{Holding Times and Preservation}

Holding times were not met for seven nitrate as nitrogen analyses. See section 3.4.5, Qualification of the Data, for additional information. Table 2.4 shows records that exceeded holding times.

Table 2.4 Holding Time Exceedances

\begin{tabular}{|l|l|l|}
\hline Type of Records & Number of Records & $\begin{array}{l}\text { Percentage of Total Environmental } \\
\text { Sample Records }\end{array}$ \\
\hline $\begin{array}{l}\text { Detects Exceeding Holding } \\
\text { Time }\end{array}$ & 7 & 0.51 \\
\hline $\begin{array}{l}\text { Nondetects Exceeding Holding } \\
\text { Time }\end{array}$ & 0 & 0.0 \\
\hline $\begin{array}{l}\text { Total Analyses Exceeding } \\
\text { Holding Time }\end{array}$ & 7 & 0.51 \\
\hline
\end{tabular}

No cooler temperatures were exceeded for this project.

\subsubsection{Analytical Issues}

No significant analytical issues were encountered during verification and validation of the analytical data.

\subsubsection{Rejected Data}

Table 2.5 summarizes the types and numbers of rejected records.

Table 2.5 Summary of Rejected Records

\begin{tabular}{|c|c|c|c|c|}
\hline Types of Records & $\begin{array}{l}\text { Number of } \\
\text { Records }\end{array}$ & $\begin{array}{l}\text { Number } \\
\text { Rejected }\end{array}$ & $\begin{array}{l}\text { Percent of Type } \\
\text { Rejected }\end{array}$ & $\begin{array}{l}\text { Percent of Total } \\
\text { Records Rejected }\end{array}$ \\
\hline \multicolumn{5}{|l|}{ Chemical } \\
\hline QC Records & 564 & 2 & 0.35 & 0.09 \\
\hline $\begin{array}{l}\text { Environmental } \\
\text { Sample Records }\end{array}$ & 659 & 0 & 0.0 & 0.0 \\
\hline \multicolumn{5}{|l|}{ Radiochemical } \\
\hline QC Records & 251 & 1 & 0.40 & 0.05 \\
\hline $\begin{array}{l}\text { Environmental } \\
\text { Sample Records }\end{array}$ & 710 & 9 & 1.30 & 0.41 \\
\hline \multicolumn{5}{|l|}{ Totals } \\
\hline QC Records & 815 & 3 & 0.37 & 0.14 \\
\hline $\begin{array}{l}\text { Environmental } \\
\text { Sample Records }\end{array}$ & 1,369 & 9 & 0.66 & 0.41 \\
\hline All Records & 2,184 & 12 & & 0.55 \\
\hline
\end{tabular}

Data Summary Report for the Annual Fourmile Branch and F- and H-Area Seeplines, Appendix IX Metals and Radionuclides, 1998

(WSRC-TR-98-00260) 


\section{Rejected Environmental Sample Records}

All nine rejected environmental sample records were rejected due to matrix interference.

Table 2.6 Environmental Sample Analytical Records Rejected

\begin{tabular}{|l|c|c|}
\hline Analyte Rejected & Number Rejected & Percent of Rejects \\
\hline Actinium-228 & 2 & 22.2 \\
\hline Barium-133 & 1 & 11.1 \\
\hline Potassium-40 & 1 & 11.1 \\
\hline Lead-212 & 5 & 55.6 \\
\hline Total & $\mathbf{9}$ & 100 \\
\hline
\end{tabular}

\section{Rejected QC Sample Records}

One lead-212 radiological method blanks was rejected due to matrix interference. Two total recoverable aluminum matrix spikes were rejected due to a high concentration of the analyte in the parent sample. No environmental sample records required qualification on the basis of these rejected $\mathrm{QC}$ samples.

Table 2.7 Rejected QC Sample Records

\begin{tabular}{|l|c|c|}
\hline Analyte Rejected & Number Rejected & Percent of Rejects \\
\hline Aluminum & 2 & 66.7 \\
\hline Lead-212 & 1 & 33.3 \\
\hline Total & $\mathbf{3}$ & $\mathbf{1 0 0}$ \\
\hline
\end{tabular}


This page was left blank intentionally. 


\subsection{Validation}

\subsection{Planning}

SAIC generated the COCs for this project according to a memo from Jim Koch to Dan Rogers.

\subsubsection{Planned Work}

Samples were to be collected from 17 sampling locations. Sample splits and duplicates were planned at a frequency of approximately one per 10 samples, to be analyzed for the same parameters as the associated sample.

Samples were to be analyzed for TAL metals (including cyanide) and Appendix IX tin, gross alpha, nonvolatile beta, gamma PHA, tritium, chloride, nitrate, nitrate/nitrite, and total hardness. For any samples that exceeded $15 \mathrm{pCi} / \mathrm{L}$ gross alpha, alpha speciation was required-, including alpha spec americium, alpha spec curium, alpha spec neptunium, alpha spec uranium, and radium-226. If nonvolatile beta exceeded $50 \mathrm{pCi} / \mathrm{L}$, beta speciation was required, to include iodine-129, nickel-63, radium-228, strontium-90, and technetium-99. The data were validated as definitive-level data.

\subsubsection{Production of Chain-of-Custody Forms}

COC forms containing the list of requested analyses for each planned sample were printed on waterproof paper. A tear-off stub attached to the COC form stipulated the sample collection location. Information completed on the COC forms included the following:

- EMS sample identification number from the logbook page for that sample

- laboratory sample identification number (to be completed by the laboratory)

- sample collection date

- shipping information (including the signature of each person handling the sample and the date it was handled)

- cooler number and temperature upon arrival at the analytical laboratory

Twenty-three COC forms were generated for this sampling event.

\subsubsection{Sample Set}

The following table lists the sample identifiers, sample type, and sample date and time for samples sent to the laboratories. $A$ in the Station ID column indicates a duplicate, and $D$ indicates a split sample. 
Table 3.1 Sample Set for FHSR03

\begin{tabular}{|l|l|l|l|l|l|}
\hline $\begin{array}{l}\text { Survey } \\
\text { Station ID }\end{array}$ & $\begin{array}{l}\text { Sample } \\
\text { ID }\end{array}$ & $\begin{array}{l}\text { Laboratory } \\
\text { ID }\end{array}$ & Sample Type & $\begin{array}{l}\text { Sample Date } \\
\text { and Time }\end{array}$ & $\begin{array}{l}\text { Analyses } \\
\text { Requesteda }\end{array}$ \\
\hline FMC001H03 & 114000 & $9804348-01$ & Seepline water & $04 / 13 / 98,08: 13$ & $1,2,3,4$ \\
\hline FMC002H03 & 114001 & $9804348-02$ & Seepline water & $04 / 13 / 98,10: 19$ & $1,2,3,4$ \\
\hline FMC001F03 & 114002 & $9804348-03$ & Seepline water & $04 / 13 / 98,11: 00$ & $1,2,3,4$ \\
\hline BG 00103 & 114003 & $9804378-01$ & Seepline water & $04 / 14 / 98,08: 28$ & $1,2,3,4$ \\
\hline BG 00203 & 114004 & $9804378-02$ & Seepline water & $04 / 14 / 98,08: 48$ & $1,2,3,4,5$ \\
\hline BG 00303 & 114005 & $9804378-03$ & Seepline water & $04 / 14 / 98,09: 35$ & $1,2,3,4$ \\
\hline HSP 00803 & 114006 & $9804378-04$ & Seepline water & $04 / 14 / 98,10: 22$ & $1,2,3,4,5$ \\
\hline HSP 00803A & 114007 & $9804378-05$ & Duplicate & $04 / 14 / 98,10: 35$ & $1,2,3,4$ \\
\hline HSP FB02C & 114008 & $9804467-06$ & Field blank & $04 / 15 / 98,10: 00$ & 1,2 \\
\hline FSP FB02C & 114009 & $9804467-07$ & Field blank & $04 / 15 / 98,11: 30$ & 1,2 \\
\hline BG 00403 & 114010 & $9804467-03$ & Seepline water & $04 / 16 / 98,08: 15$ & $1,2,3,4$ \\
\hline HSP 09203 & 114011 & $9804467-04$ & Seepline water & $04 / 16 / 98,09: 12$ & $1,2,3,4,5$ \\
\hline HSP 06003 & 114012 & $9804467-01$ & Seepline water & $04 / 16 / 98,10: 10$ & $1,2,3,4$ \\
\hline HSP 06003D & 114013 & $9804 L 553-001$ & Split & $04 / 16 / 98,10: 10$ & $1,2,3,4$ \\
\hline HSP 02903 & 114014 & $9804467-05$ & Seepline water & $04 / 16 / 98,11: 55$ & $1,2,3,4,5,6$ \\
\hline HSP 04303 & 114015 & $9804467-02$ & Seepline water & $04 / 16 / 98,12: 40$ & $1,2,3,4,6$ \\
\hline FSP 29003 & 114016 & $9804586-01$ & Seepline water & $04 / 21 / 98,08: 55$ & $1,2,3,4$ \\
\hline FSP 29003A & 114017 & $9804586-02$ & Duplicate & $04 / 21 / 98,09: 10$ & $1,2,3,4$ \\
\hline FSP 20403 & 114018 & $9804586-03$ & Seepline water & $04 / 21 / 98,10: 00$ & $1,2,3,4,5,6$ \\
\hline FSP 01203 & 114019 & $9804586-04$ & Seepline water & $04 / 21 / 98,10: 20$ & $1,2,3,4$ \\
\hline FSP 04703 & 114020 & $9804586-05$ & Seepline water & $04 / 21 / 98,10: 50$ & $1,2,3,4$ \\
\hline FSP 03203 & 114021 & $9804586-06$ & Seepline water & $04 / 21 / 98,11: 30$ & $1,2,3,4,6$ \\
\hline FSP 03203D & 114022 & $9804 L 553-002$ & Split & $04 / 21 / 98,11: 40$ & $1,2,3,4,6,7$ \\
\hline
\end{tabular}

\subsection{Field Data Quality Issues}

\subsubsection{Discrepancies from the Planned Work}

Strontium-90 and technetium-99 and were listed on the GE COCs, but were crossed off and initialed "JWK" with an appropriate date; none of the analyses was performed.

Technetium-99 was not included on the COCs sent to Recra. However, strontium-90 was

a 1. Appendix IX tin, TAL metals (including cyanide)

2. Gross alpha, nonvolatile beta, gamma speciation

3. Tritium

4. Chloride, nitrate, nitrate/nitrite, total hardness

5. Contingent alpha speciation (americium-241, uranium series, curium-series, radium-226, neptunium-237)

6. Contingent beta speciation (radium-228, iodine-129, nickel-63)

7. Contingent beta analyte strontium-90

Data Summary Report for the Annual Fourmile Branch and

F- and H-Area Seeplines, Appendix IX Metals and Radionuclides, 1998

(WSRC-TR-98-00260) 
listed as a contingent beta speciation analyte and was reported when nonvolatile beta results exceeded trigger levels.

\subsubsection{Sample Logbook Observations}

There were no sample logbook observations that affected data quality.

\subsubsection{Chain-of-Custody Observations}

As noted previously, strontium-90 and technetium-99 were marked out on the COCs sent to GE.

There were no COC observations that affected data quality.

\subsection{Analytical Data Quality Issues}

\subsubsection{The Laboratories}

Environmental samples were analyzed by GE under contract AA07208N and split samples were analyzed by Recra under contract AA07210N. Both laboratories have been certified by SCDHEC.

\subsubsection{Laboratory Quality Control}

The laboratories follow their own QA/QC plans, which are designed to measure and document the accuracy and precision for the various sample control and analytical methods it performs. The laboratories are guided by published method-specific QC requirements as well as other regulatory and contract-required QC procedures.

\subsubsection{List of Analytical Suites}

Samples were to be analyzed for the following:

- TAL metals

- TAL cyanide

- Appendix IX tin

- Gross alpha (For any samples that exceeded $15 \mathrm{pCi} / \mathrm{L}$ gross alpha, alpha speciation was required, including alpha spec americium, alpha spec curium, alpha spec neptunium, alpha spec uranium, and radium-226.)

- Nonvolatile beta (If nonvolatile beta exceeded $50 \mathrm{pCi} / \mathrm{L}$, beta speciation was required, to include iodine-129, nickel-63, radium-228, and strontium-90 for Recra samples only.)

- Gamma PHA

- Tritium

- Other: chloride, nitrate, nitrate/nitrite, and total hardness.

Data Summary Report for the Annual Fourmile Branch and

F- and H-Area Seeplines, Appendix IX Metals and Radionuclides, 1998

(WSRC-TR-98-00260) 
The data were validated as definitive-level data. See Appendix $A$ for a listing of the analytical methods and the lab's' reporting of MDAs.

\subsubsection{Analytical Data Observations}

The data are final and complete except as noted in this subsection. Data validation is also complete.

Some of the data did not meet all the criteria listed in EPA, 1993, as noted below:

- Field measurements are designed to meet the criteria for screening-level data and they are not analyte specific. Therefore, definitive data criteria are not applicable.

- Analytical error determination (a measurement of method precision) was not calculated; however, precision can be evaluated by referring to the tables in section 3.5, Precision and Accuracy, of this report.

- Total measurement error determination (measurement of overall precision from sample acquisition through analysis) was not performed because it requires independently collected samples from the same location, and this practice does not fit into the scope of the project work plan.

- No adjustments to sample values were made for bias or precision.

- Using the criteria defined in EPA, 1993, matrix spike recoveries for an entire project are averaged, and all associated sample data are qualified on the basis of this average. Matrix spike-based qualification for this project, however, was done on a sample-bysample basis, using the criteria in subsection 3.4.5, Qualification of the Data.

- Two matrix spikes of project samples could not be evaluated due to high concentration of the analyte in the sample.

\subsection{Verification and Validation Issues}

\subsubsection{Analytical Narrative Review}

The EDDs and analytical narratives arrive from the laboratories and are logged in together. If the analytical narrative is missing, it is requested from the analytical laboratory. The narratives are reviewed and used as a reference throughout the data validation process. Discrepancies between the narratives and the analytical data must be resolved by the analytical laboratory. The analytical narratives contain summaries of the following problems encountered by the laboratory:

- QC samples that do not meet the criteria specified by the analytical method

- matrix interference problems

- sample-specific adjustments to the method caused by high concentration of some analytes

- sample preservation and holding time problems

- instrument calibration problems

Data Summary Report for the Annual Fourmile Branch and

F- and H-Area Seeplines, Appendix IX Metals and Radionuclides, 1998

(WSRC-TR-98-00260) 
- contaminated blanks

- other laboratory QC issues

Additional information about the chain-of-custody data and analytical data is often found in the analytical narratives. Copies of the COC forms attached to the analytical narratives are used for data review.

\subsubsection{Laboratory Data Records Review}

A laboratory data records review (LDRR) was originally scheduled for this project, but was canceled because of the small size of the project.

\subsubsection{ICP Data Evaluation}

An evaluation of the metals analyzed by inductively coupled plasma atomic emission spectroscopy (ICP) at GE indicated that no analytical results produced by ICP will require requalification. All reported aluminum and iron results were too low to interfere significantly with other metals.

\subsubsection{Radiological Data Review}

On July 31, 1998, Walt Kubilius of EMS reviewed laboratory instrument printouts at EP for radiological data from this project. The objective of the review was to evaluate data for false positive results. No requalification of analytical records was necessary based on the review.

\subsubsection{Qualification of the Data}

Each sample was evaluated on the following issues during validation:

- holding time

- sample preservation

- instrument calibration

- analyte identification and quantitation

- method blanks

- laboratory control samples

- rinsates, field blanks, and field duplicates

- laboratory duplicates

- matrix spikes

- instrument readings

- additional information 


\section{Holding Time}

Criteria

Each analysis was evaluated according to the holding time limits for preparation (extraction or digestion) and analysis given in the following table.

Table 3.2 Holding Time Criteria

\begin{tabular}{|c|c|c|c|}
\hline Analytes & Reference & Extraction/Digestion & Analysis \\
\hline Cation exchange capacity & EPA, 1986 & $\mathrm{NA}$ & $\mathrm{NA}$ \\
\hline Cyanide & EPA, 1994a & $\mathrm{NA}$ & 14 days from collection \\
\hline Mercury & EPA, 1994a & NA & 28 days from collection \\
\hline Metals & EPA, 1994a & $\mathrm{NA}$ & 6 months from collection \\
\hline Nitrate & EPA, 1994a & $\mathrm{NA}$ & 48 hours from collection \\
\hline Nitrogen (Kjeldahl method) & EPA, 1994a & $\mathrm{NA}$ & 28 days from collection \\
\hline Orthophosphate & EPA, 1994a & NA & 48 hours from collection \\
\hline Pesticide (soil) & EPA, 1994a & 14 days from collection & 40 days from extraction \\
\hline Pesticide (water) & EPA, 1994a & 7 days from collection & 40 days from extraction \\
\hline Radionuclides & EPA, 1994a & $\mathrm{NA}$ & 6 months from collection \\
\hline Semivolatile organics (soil) & EPA, 1994a & 14 days from collection & 40 days from extraction \\
\hline $\begin{array}{l}\text { Semivolatile organics } \\
\text { (water) }\end{array}$ & EPA, 1994a & 7 days from collection & 40 days from extraction \\
\hline Sulfate & EPA, 1994a & $\mathrm{NA}$ & 28 days from collection \\
\hline Total organic carbon & EPA, 1986 & NA & 28 days from collection \\
\hline Total phosphorus as $\mathrm{P}$ & EPA, 1994a & $\mathrm{NA}$ & 28 days from collection \\
\hline Turbidity & EPA, 1994a & $\mathrm{NA}$ & 48 hours from collection \\
\hline Volatile organics & EPA, 1994a & $\mathrm{NA}$ & 14 days from collection \\
\hline
\end{tabular}

\section{Action}

When holding times were exceeded, the following qualifiers were applied:

Analysis Qualifier: $Q$

Result Qualifier: $J$-for detects $\quad U J$-for nondetects

\section{Findings}

Five of 1,369 environmental sample records were qualified based on holding times.

Table 3.3 Holding Times Exceeded by GE

\begin{tabular}{|l|l|l|l|l|l|l|l|}
\hline $\begin{array}{l}\text { Sample } \\
\text { W }\end{array}$ & Method & $\begin{array}{l}\text { Number of } \\
\text { Results }\end{array}$ & $\begin{array}{l}\text { Sample } \\
\text { Date }\end{array}$ & $\begin{array}{l}\text { Ext. } \\
\text { Date }\end{array}$ & $\begin{array}{l}\text { Ext. } \\
\text { Limit }\end{array}$ & $\begin{array}{l}\text { Analysis } \\
\text { Date }\end{array}$ & $\begin{array}{l}\text { Analysis } \\
\text { Limit }\end{array}$ \\
\hline Specified Analyses \\
\hline 114000 & EPA300.0 & 3 & $04 / 13 / 98$ & & & $04 / 16 / 98$ & $04 / 15 / 98$ \\
\hline
\end{tabular}

Data Summary Report for the Annual Fourmile Branch and

F- and H-Area Seeplines, Appendix IX Metals and Radionuclides, 1998

(WSRC-TR-98-00260) 
Table 3.3 Holding Times Exceeded by GE (cont.)

\begin{tabular}{|l|l|l|l|l|l|l|l|}
\hline $\begin{array}{l}\text { Sample } \\
\text { ID }\end{array}$ & Method & $\begin{array}{l}\text { Number of } \\
\text { Results }\end{array}$ & $\begin{array}{l}\text { Sample } \\
\text { Date }\end{array}$ & $\begin{array}{l}\text { Ext. } \\
\text { Date }\end{array}$ & $\begin{array}{l}\text { Ext. } \\
\text { Limit }\end{array}$ & $\begin{array}{l}\text { Analysis } \\
\text { Date }\end{array}$ & $\begin{array}{l}\text { Analysis } \\
\text { Limit }\end{array}$ \\
\hline 114001 & EPA300.0 & 1 & $04 / 13 / 98$ & & & $04 / 16 / 98$ & $04 / 15 / 98$ \\
\hline 114002 & EPA300.0 & 1 & $04 / 13 / 98$ & & & $04 / 16 / 98$ & $04 / 15 / 98$ \\
\hline
\end{tabular}

Table 3.4 Holding Times Exceeded by Recra

\begin{tabular}{|l|l|l|l|l|l|l|l|}
\hline $\begin{array}{l}\text { Sample } \\
\text { ID }\end{array}$ & Method & $\begin{array}{l}\text { Number of } \\
\text { Results }\end{array}$ & $\begin{array}{l}\text { Sample } \\
\text { Date }\end{array}$ & $\begin{array}{l}\text { Ext. } \\
\text { Date }\end{array}$ & $\begin{array}{l}\text { Ext. } \\
\text { Limit }\end{array}$ & $\begin{array}{l}\text { Analysis } \\
\text { Date }\end{array}$ & $\begin{array}{l}\text { Analysis } \\
\text { Limit }\end{array}$ \\
\hline Specified Analyses \\
\hline 114013 & EPA353.2 & 1 & $04 / 16 / 98$ & & & $04 / 24 / 98$ & $04 / 18 / 98$ \\
\hline 114022 & EPA353.2 & 1 & $04 / 21 / 98$ & & & $04 / 24 / 98$ & $04 / 23 / 98$ \\
\hline
\end{tabular}

\section{Discussion}

Most methods specify limits on the time that can pass between sample collection and extraction or analysis. When holding times are exceeded, sample integrity may be compromised due to chemical and/or physical effects that can bias sample results either positively or negatively.

\section{Sample Preservation}

\section{Criteria}

Sample preservation requirements are determined by regulatory guidance, method specifications, and laboratory protocols.

Findings

No environmental sample records were qualified based on sample preservation.

\section{Instrument Calibration}

\section{Criteria}

The calibration criteria specific to each method was used to evaluate instrument calibration during the LDRR.

Action

When calibration criteria were not met, the following qualifiers were assigned:

Analysis Qualifier: $L$

Result Qualifiers: $\quad J$ or $R$-detects $\quad U J$-for nondetects

\section{Findings}

No environmental sample records were qualified based on instrument calibration.

Data Summary Report for the Annual Fourmile Branch and

F- and H-Area Seeplines, Appendix IX Metals and Radionuclides, 1998

(WSRC-TR-98-00260) 


\section{Discussion}

Instrument calibration ensures that the instrument is capable of producing acceptable quantitative results. Initial calibration demonstrates that the instrument is capable of acceptable performance at the beginning of the analysis run. Continuing calibration verification documents that the initial calibration is still valid. After initial calibration, a continuing calibration standard and blank should be analyzed after every 10 samples.

\section{Analyte Identification and Quantitation}

This issue was examined during the LDRR. The findings are presented in section 3.4.2, Laboratory Data Records Review.

\section{Trip Blanks}

\section{Criteria}

Trip blanks are used to determine the existence and magnitude of contamination from shipping activities.

\section{Action}

When an analyte is detected in a trip blank, an analysis qualifier is assigned to that analyte in the blank and to all samples that are shipped in the same cooler as the trip blank having positive results. If the analyte concentration in a sample is less than five times that in the blank (less than 10 times for the common laboratory contaminants acetone, dichloromethane [methylene chloride], and methyl ethyl ketone), assign a result qualifier to that analyte in the sample.

The following qualifiers may be assigned:

Analysis Qualifier: 8

Result Qualifier: $\quad U$

\section{Findings}

There were no trip blanks associated with this project.

\section{Discussion}

Volatile organic contamination can be introduced into a trip blank in three ways: during blank preparation at the laboratory; during storage of the trip blank in the cooler; or by cross-contamination from other samples. The contamination can cause false positives in the trip blank and in the samples exposed to contamination. 


\section{Method Blanks}

\section{Criteria}

Method blanks are used to determine the existence and magnitude of contamination from laboratory activities. Method blanks with analytical results greater than zero are considered to be contaminated. The CLP $5 \times / 10 \times$ rule is used for data qualification.

\section{Action}

When an analyte is detected in a method blank, an analysis qualifier is assigned to that analyte in the blank and to every sample of the preparation batch having positive results. If the analyte concentration in a sample is less than five times that in the blank (less than 10 times for common laboratory contaminants), assign a result qualifier to that analyte in the sample. A bias qualifier should be used only if the laboratory believes the sample is contaminated and has assigned the qualifier.

The following qualifiers may be assigned:

$\begin{array}{ll}\text { Analysis Qualifier: } & V \\ \text { Result Qualifier: } & U \\ \text { Bias Qualifier: } & H\end{array}$

\section{Findings}

Of 1,369 environmental sample records, 139 were qualified based on method blank contamination.

\section{Table 3.5 Method Blank Contamination by GE}

\begin{tabular}{|c|c|}
\hline Analyte & Frequency Detected \\
\hline \multicolumn{2}{|l|}{ Specified Analyses } \\
\hline Chloride & $3 / 4$ \\
\hline Nitrate as nitrogen & $3 / 4$ \\
\hline Nitrate-nitrite as nitrogen & $1 / 4$ \\
\hline \multicolumn{2}{|l|}{ Metals (total recoverable) } \\
\hline Aluminum & $1 / 5$ \\
\hline Calcium & $5 / 6$ \\
\hline Iron & $1 / 5$ \\
\hline Lead & $2 / 5$ \\
\hline Magnesium & $2 / 5$ \\
\hline Manganese & $2 / 5$ \\
\hline Mercury & $1 / 4$ \\
\hline Potassium & $2 / 5$ \\
\hline Silver & $3 / 5$ \\
\hline
\end{tabular}

Data Summary Report for the Annual Fourmile Branch and

F- and H-Area Seeplines, Appendix IX Metals and Radionuclides, 1998

(WSRC-TR-98-00260) 
Table 3.5 Method Blank Contamination by GE (cont.)

\begin{tabular}{|l|l|}
\hline Analyte & Frequency Detected \\
\hline Sodium & $4 / 5$ \\
\hline Zinc & $3 / 5$ \\
\hline
\end{tabular}

Table 3.6 Method Blank Contamination by Recra

\begin{tabular}{|l|l|}
\hline Analyte & Frequency Detected \\
\hline Specified Analyses & $1 / 1$ \\
\hline Barium & $1 / 1$ \\
\hline Magnesium & $1 / 1$ \\
\hline Sodium &
\end{tabular}

Table 3.7 Method Blank Contamination by EP

\begin{tabular}{|l|l|}
\hline Analyte & Frequency Detected \\
\hline Radionuclides & \\
\hline Americium-241 & $1 / 2$ \\
\hline Lead-212 & $1 / 2$ \\
\hline
\end{tabular}

\section{Discussion}

Laboratory contamination of samples during preparation and/or analysis is monitored through the method blank. Laboratory procedures may cause false positive results in the method blanks for common laboratory contaminants.

\section{Laboratory Control Samples}

\section{Criteria}

- Dioxins/furans: 40-120\% recovery (EPA, 1986)

- Inorganics: 80-120\% recovery except EPA6020 and EPA6020A, which have 70-130\% recovery

- Pesticides: Page D-61 PEST (EPA, 1991b)

- Radiologicals: 80-120\% (WHC, not dated)

- Semivolatiles: Table 7, page D-59 SV (EPA, 1991b)

- Volatiles: Table 7, page D-55 VOA (EPA, 1991b)

Data Summary Report for the Annual Fourmile Branch and F- and H-Area Seeplines, Appendix IX Metals and Radionuclides, 1998

(WSRC-TR-98-00260) 


\section{Action}

When the percent recovery for an analyte in the LCS was outside the QC limits, that analyte in the LCS was qualified with an analysis qualifier. That analyte in each sample of the preparation batch was qualified. If an LCS was not included in the preparation batch, all spike compounds for the associated samples were qualified with an analysis and a results qualifier.

LCS recovery below lower QC limit:

Analysis Qualifier: C

Result Qualifiers: $J$-for detects $\quad U J$-for nondetects

LCS recovery above upper QC limit:

Analysis Qualifier: $C$

Result Qualifiers: J-for detects

\section{Findings}

Three of 1,369 environmental sample records were qualified based on laboratory control and blank spike recoveries. The preparation batch was used to correlate the samples with the spikes.

Table 3.8 Laboratory Control Samples and Blank Spikes Outside Ranges for EP

\begin{tabular}{|l|l|}
\hline Analyte & Frequency Detected \\
\hline Radionuclides & $1 / 3$ \\
\hline Iodine-129
\end{tabular}

Table 3.9 Laboratory Control Samples and Blank Spikes Outside Ranges for TNU

\begin{tabular}{|l|l|}
\hline Analyte & Frequency Detected \\
\hline Radionuclides & $1 / 1$ \\
\hline Nickel-63
\end{tabular}

\section{Discussion}

LCS percent recoveries that exceed the upper QC limit could indicate a high bias for samples with positive results. Percent recoveries that are less than the lower QC limit could indicate a low bias for samples with positive results, and nondetect results should be considered questionable.

\section{Field Blanks}

\section{Criteria}

Field blanks are used to determine the existence and magnitude of contamination from the processing and shipping of samples. 


\section{Action}

When an analyte is detected in a field blank, an analysis qualifier is assigned to that analyte in the blank and to positive results of that analyte for all samples accociated with that blank. Samples associated include all samples from a soil boring taken while the field blank is exposed to the environment or a well cluster sampled on the same day and approximate time as a field blank is assigned. If the analyte concentration in a sample is less than five times that in the blank (less than 10 times for the common laboratory contaminants acetone, dichloromethane [methylene chloride], and methyl ethyl ketone), a result qualifier is assigned to that analyte in the sample.

The following qualifiers may be assigned:

Analysis Qualifier: 6

Result Qualifier: U

\section{Findings}

The field blanks for this project were not associated with any samples because the sample date for the field blanks recorded in the sample logbooks did not correlate with any project samples. Therefore, the analysis qualifier 6 was not assigned to any analytes in the analytical data.

\section{Discussion}

Positive results in field blanks can be attributed to contaminated sample bottles, DI water or quartz sand, contamination during shipping, or environmental exposure during sampling. The contamination can cause false positives in the field blank and in the samples exposed to the same contamination.

\section{Rinsate Blanks and Field Duplicates}

No qualification is performed based on rinsate blanks and field duplicates.

\section{Laboratory Duplicates}

\section{Criteria}

- Inorganics: Page 10 (EPA, 1988a)

- Organics: No qualification is done on this basis.

- Radiologicals: (WHC, not dated)

\section{Findings}

Four of 1,369 environmental sample records were qualified based on RPDs. 
Table 3.10 Laboratory Duplicate Results Outside RPD Limits by TNU

\begin{tabular}{|l|l|l|l|l|l|l|}
\hline $\begin{array}{l}\text { Sample } \\
\text { ID }\end{array}$ & Analyte & $\begin{array}{l}\text { Sample } \\
\text { Conc. }\end{array}$ & $\begin{array}{l}\text { Duplicate } \\
\text { Conc. }\end{array}$ & Unit & RPD (\%) & $\begin{array}{l}\text { Acceptance } \\
\text { Limit (\%) }\end{array}$ \\
\hline 114013 & Nonvolatile beta & 34.75 & 26.68 & $\mathrm{pCi} / \mathrm{L}$ & 26.27 & 20 \\
\hline 114013 & Promethium-144 & 1.14 & 19.07 & $\mathrm{pCi} / \mathrm{L}$ & 177.4 & 20 \\
\hline
\end{tabular}

Discussion

Poor precision (i.e., high RPDs) can be caused by poor instrument performance, inconsistent application of method procedures, the heterogeneous nature of soil samples, or low quantities of an analyte in the sample.

\section{Matrix Spikes}

\section{Criteria}

- Dioxins: 40-120\% (EPA, 1986)

- Inorganics: Page 11 (EPA, 1988a)

- Pesticides: Page D-61 PEST (EPA, 1991b)

- Semivolatiles: Table 7, page D-59 SV (EPA, 1991b)

- Volatiles: Table 7, page D-55 VOA (EPA, 1991b)

Action

1. MS recovery limits do not apply when the spike concentration is less than $25 \%$ of the sample concentration. When this occurred, the MS record only was qualified as follows:

Analysis Qualifier: 5

Result Qualifier: $\quad R$

2. If the laboratory did not perform matrix spikes for nonradiological analyses, the following qualifier was used:

Analysis Qualifier: I

\section{Findings}

Twenty of 1,369 environmental sample records were qualified based on matrix spike recoveries. Table 3.11 lists matrix spike recoveries outside EPA recovery limits and table 3.12 lists the frequency with which matrix spikes were rejected because the sample concentration was four times higher than the nominal concentration. 
Table 3.11 Matrix Spike Recoveries Outside the EPA Recovery Limits by GE

\begin{tabular}{|l|l|l|l|l|l|}
\hline $\begin{array}{l}\text { Sample } \\
\text { ID }\end{array}$ & Lab ID & Analyte & $\begin{array}{l}\text { EPA } \\
\text { Minimum (\%) }\end{array}$ & $\begin{array}{l}\text { EPA } \\
\text { Maximum (\%) }\end{array}$ & $\begin{array}{l}\text { Recovery } \\
(\%)\end{array}$ \\
\hline 114007 & QC500790 & Aluminum & 80 & 120 & 40.2 \\
\hline 114007 & QC500791 & Aluminum & 80 & 120 & 52.2 \\
\hline 114009 & QC501407 & Cyanide & 80 & 120 & 73.2 \\
\hline
\end{tabular}

Table 3.12 Matrix Spikes With Sample Concentrations Four Times Higher Than Nominal Concentration for Samples by GE

\begin{tabular}{|l|l|}
\hline Analyte & Rejection Frequency \\
\hline Metals (total recoverable) & \\
\hline Aluminum & $2 / 8$ \\
\hline
\end{tabular}

\section{Discussion}

When the matrix spike percent recovery for an analyte is high, the results for associated data may be biased positively. When the matrix spike percent recovery for an analyte is low, the results for associated data may be biased negatively, and the nondetected results should be considered questionable.

\section{Instrument Readings}

\section{Criteria}

For radiologicals, nondetected parameters reported from an instrument reading require a result qualifier.

\section{Action}

The result qualifier was as follows:

Result Qualifier: $\quad U I$-for nondetects

\section{Findings}

Of 1,369 environmental sample records, 601 qualified as instrument readings.

\section{Discussion}

For radiological analyses, the laboratory instrumentation and data management software calculate the MDA, result, and accuracy. If the reported result was less than the MDA and/or the accuracy, a $U I$ result qualifier was assigned.

\subsection{Precision and Accuracy}

This section discusses the analytical data in terms of the precision and accuracy indicators of data quality. Precision is determined from the field and laboratory duplicate analyses and indicates the consistency of field and laboratory techniques. Accuracy is determined 
from the laboratory control samples, matrix spikes, and the results of the method, field, trip, and equipment blanks or rinsates and indicates the ability of the laboratory to generate correct results.

\subsubsection{Precision}

Precision is a measure of the repeatability of a measurement and is evaluated from the results of field and laboratory duplicate samples. Field duplicates measure the repeatability for the sampling and analytical techniques, and laboratory duplicates measure the ability of the laboratory to reproduce a result. Low precision can be caused by poor instrument performance, poor operator technique, inconsistent application of method protocols, laboratory environment, time between analyses, or by a difficult, heterogeneous sample matrix. Precision is especially important when the action limit approaches the quantitation limit. At least $5 \%$ of the samples are collected in duplicate. The laboratory performs duplicate analyses on at least $10 \%$ of the samples received.

Precision is expressed in terms of the relative percent difference as follows:

$$
\mathrm{RPD}=\frac{|x-y|}{\left(\frac{x+y}{2}\right)} \times 100,
$$

where $x$ is the original sample result and $y$ is the duplicate sample result. When one result of a duplicate pair is below the MDL, the sSEQL is used for that result in the calculation. When both results are below the MDL, the RPD cannot be calculated.

The RPD should be less than $20 \%$ for water samples and less than $35 \%$ for soil samples when results are above the ssEQL. In the case where results are between the ssEQL and the MDL, the RPD should be less than $100 \%$ for water samples and less than $200 \%$ for soil samples.

The RPDs for the laboratory and field duplicates are listed in the following tables. The frequency out of range is the number of duplicates that had RPDs greater than the acceptance limit compared to the total number analyzed; the other columns provide the mean RPD, standard deviation, and the minimum and maximum RPDs.

Table 3.13 Relative Percent Differences of Laboratory Duplicates by GE

\begin{tabular}{|l|l|l|l|l|l|}
\hline \multicolumn{2}{|l|}{$\begin{array}{l}\text { Frequency } \\
\text { Out of } \\
\text { Range }\end{array}$} & $\begin{array}{l}\text { Mean } \\
\text { RPD (\%) }\end{array}$ & $\begin{array}{l}\text { Std. } \\
\text { Dev. }\end{array}$ & $\begin{array}{l}\text { Minimum } \\
\text { RPD (\%) }\end{array}$ & $\begin{array}{l}\text { Maximum } \\
\text { RPD (\%) }\end{array}$ \\
\hline Specified Analyses & \multicolumn{5}{l|}{} \\
\hline Chloride & $0 / 4$ & 5.6 & 3.62 & 0.952 & 9.77 \\
\hline Cyanide & $0 / 2$ & 0 & 0 & 0 & 0 \\
\hline Hardness as CACO3 & $0 / 3$ & 10.2 & 9.3 & 0 & 18.2 \\
\hline Nitrate as nitrogen & $0 / 4$ & 4.09 & 3.03 & 0.966 & 7.67 \\
\hline Nitrate-nitrite as nitrogen & $0 / 1$ & 0.851 & & 0.851 & 0.851 \\
\hline
\end{tabular}

Data Summary Report for the Annual Fourmile Branch and

F- and H-Area Seeplines, Appendix IX Metals and Radionuclides, 1998

(WSRC-TR-98-00260) 
Table 3.14 Relative Percent Differences of Laboratory Duplicates by Recra

\begin{tabular}{|c|c|c|c|c|c|}
\hline Analyte & $\begin{array}{l}\text { Frequency } \\
\text { Out of } \\
\text { Range }\end{array}$ & $\begin{array}{l}\text { Mean } \\
\text { RPD (\%) }\end{array}$ & $\begin{array}{l}\text { Std. } \\
\text { Dev. }\end{array}$ & $\begin{array}{l}\text { Minimum } \\
\text { RPD (\%) }\end{array}$ & $\begin{array}{l}\text { Maximum } \\
\text { RPD }(\%)\end{array}$ \\
\hline \multicolumn{6}{|l|}{ Specified Analyses } \\
\hline Cyanide & $0 / 1$ & 0 & & 0 & 0 \\
\hline Hardness as $\mathrm{CACO} 3$ & $0 / 1$ & 4.26 & & 4.26 & 4.26 \\
\hline \multicolumn{6}{|c|}{ Metals (total recoverable) } \\
\hline Mercury & $0 / 1$ & 0 & & 0 & 0 \\
\hline
\end{tabular}

Table 3.15 Relative Percent Differences of Laboratory Duplicates by EP

\begin{tabular}{|c|c|c|c|c|c|}
\hline Analyte & $\begin{array}{l}\text { Frequency } \\
\text { Out of } \\
\text { Range }\end{array}$ & $\begin{array}{l}\text { Mean } \\
\text { RPD (\%) }\end{array}$ & $\begin{array}{l}\text { Std. } \\
\text { Dev. }\end{array}$ & $\begin{array}{l}\text { Minimum } \\
\text { RPD (\%) }\end{array}$ & $\begin{array}{l}\text { Maximum } \\
\text { RPD (\%) }\end{array}$ \\
\hline \multicolumn{6}{|l|}{ Rądionuclides } \\
\hline Actinium-228 & $1 / 2$ & 54.4 & 76.9 & 0 & 109 \\
\hline Americium-241 & $0 / 1$ & 0 & & 0 & 0 \\
\hline Antimony-124 & $0 / 2$ & 0 & 0 & 0 & 0 \\
\hline Antimony-125 & $0 / 2$ & 0 & 0 & 0 & 0 \\
\hline Barium-133 & $0 / 2$ & 0 & 0 & 0 & 0 \\
\hline Cerium-144 & $0 / 2$ & 0 & 0 & 0 & 0 \\
\hline Cesium-134 & $0 / 2$ & 0 & 0 & 0 & 0 \\
\hline Cesium-137 & $0 / 2$ & 0 & 0 & 0 & 0 \\
\hline Cobalt-57 & $0 / 2$ & 0 & 0 & 0 & 0 \\
\hline Cobalt-58 & $0 / 2$ & 0 & 0 & 0 & 0 \\
\hline Cobalt-60 & $0 / 2$ & 2.54 & 3.6 & 0 & 5.09 \\
\hline Curium-242 & $0 / 1$ & 0 & & 0 & 0 \\
\hline Curium-243/244 & $0 / 1$ & 0 & & 0 & 0 \\
\hline Curium-245/246 & $0 / 1$ & 0 & & 0 & 0 \\
\hline Europium-152 & $0 / 2$ & 0 & 0 & 0 & 0 \\
\hline Europium-154 & $0 / 2$ & 0 & 0 & 0 & 0 \\
\hline Europium-155 & $0 / 2$ & 0 & 0 & 0 & 0 \\
\hline Gross alpha & $0 / 0$ & & & & \\
\hline Iodine-129 & $1 / 2$ & 17.2 & 24.3 & 0 & 34.3 \\
\hline Lead-212 & $0 / 2$ & 0 & 0 & 0 & 0 \\
\hline Manganese-54 & $0 / 2$ & 0 & 0 & 0 & 0 \\
\hline Neptunium-237 & $1 / 1$ & 43.4 & & 43.4 & 43.4 \\
\hline Neptunium-239 & $0 / 2$ & 0 & 0 & 0 & 0 \\
\hline Nickel-63 & $0 / 1$ & 0 & & 0 & 0 \\
\hline Nonvolatile beta & $0 / 0$ & & & & \\
\hline Potassium-40 & $0 / 2$ & 0 & 0 & 0 & 0 \\
\hline
\end{tabular}

Data Summary Report for the Annual Fourmile Branch and F- and H-Area Seeplines, Appendix IX Metals and Radionuclides, 1998

(WSRC-TR-98-00260) 
Table 3.15 Relative Percent Differences of Laboratory Duplicates by EP (cont.)

\begin{tabular}{|l|l|l|l|l|l|}
\hline & $\begin{array}{l}\text { Frequency } \\
\text { Out of } \\
\text { Range }\end{array}$ & $\begin{array}{l}\text { Mean } \\
\text { RPD (\%) }\end{array}$ & $\begin{array}{l}\text { Std. } \\
\text { Dev. }\end{array}$ & $\begin{array}{l}\text { Minimum } \\
\text { RPD (\%) }\end{array}$ & $\begin{array}{l}\text { Maximum } \\
\text { RPD (\%) }\end{array}$ \\
\hline Promethium-144 & $0 / 2$ & 0 & 0 & 0 & 0 \\
\hline Promethium-146 & $0 / 2$ & 0 & 0 & 0 & 0 \\
\hline Radium-226 & $0 / 2$ & 12.8 & 6.62 & 8.16 & 17.5 \\
\hline Radium-228 & $0 / 1$ & 0 & & 0 & 0 \\
\hline Ruthenium-106 & $0 / 2$ & 0 & 0 & 0 & 0 \\
\hline Sodium-22 & $0 / 2$ & 0 & 0 & 0 & 0 \\
\hline Tin-113 & $0 / 2$ & 0 & 0 & 0 & 0 \\
\hline Tritium & $0 / 0$ & & & & \\
\hline Uranium-233/234 & $0 / 1$ & 11.5 & & 11.5 & 11.5 \\
\hline Uranium-235 & $0 / 1$ & 0 & & 0 & 0 \\
\hline Uranium-238 & $1 / 1$ & 199 & & 199 & 199 \\
\hline Yttrium-88 & $0 / 2$ & 0 & 0 & 0 & 0 \\
\hline Zinc-65 & $0 / 2$ & 0 & 0 & 0 & 0 \\
\hline Zirconium-95 & $0 / 2$ & 0 & 0 & 0 & 0 \\
\hline
\end{tabular}

Table 3.16 Relative Percent Differences of Laboratory Duplicates by TNU

\begin{tabular}{|l|l|l|l|l|l|l|}
\hline \multicolumn{2}{|l|}{$\begin{array}{l}\text { Frequency } \\
\text { Out of } \\
\text { Range }\end{array}$} & $\begin{array}{l}\text { Mean } \\
\text { RPD (\%) }\end{array}$ & $\begin{array}{l}\text { Std. } \\
\text { Dev. }\end{array}$ & $\begin{array}{l}\text { Minimum } \\
\text { RPD (\%) }\end{array}$ & $\begin{array}{l}\text { Maximum } \\
\text { RPD (\%) }\end{array}$ \\
\hline Radionuclides & $0 / 1$ & & 0 & 0 \\
\hline Actinium-228 & $0 / 1$ & 0 & 0 & 0 \\
\hline Antimony-124 & $0 / 1$ & 0 & 0 & 0 \\
\hline Antimony-125 & $0 / 1$ & 0 & & 0 & 0 \\
\hline Barium-133 & $0 / 1$ & 0 & 0 & 0 \\
\hline Cerium-144 & $0 / 1$ & 0 & & 0 & 0 \\
\hline Cesium-134 & $0 / 1$ & 0 & & 0 & 0 \\
\hline Cesium-137 & $0 / 1$ & 0 & 0 & 0 \\
\hline Cobalt-57 & $0 / 1$ & 0 & & 0 & 0 \\
\hline Cobalt-58 & $0 / 1$ & 0 & & 0 & 0 \\
\hline Cobalt-60 & $0 / 1$ & 0 & & 0 & 0 \\
\hline Europium-152 & $0 / 1$ & 0 & & 0 & 0 \\
\hline Europium-154 & $0 / 1$ & 0 & & 0 & 0 \\
\hline Europium-155 & $1 / 1$ & 34.3 & & 34.3 & 34.3 \\
\hline Gross alpha & $0 / 1$ & 0 & & 0 & 0 \\
\hline Iodine-129 & $1 / 1$ & 313 & & 313 & 313 \\
\hline Lead-212 & $0 / 1$ & 0 & 0 & 0 \\
\hline Manganese-54 & $0 / 1$ & 0 & & 0 \\
\hline Nickel-63 & & & & \\
\hline
\end{tabular}

Data Summary Report for the Annual Fourmile Branch and

F- and H-Area Seeplines, Appendix IX Metals and Radionuclides, 1998

(WSRC-TR-98-00260) 
Table 3.16 Relative Percent Differences of Laboratory Duplicates by TNU (cont.)

\begin{tabular}{|l|l|l|l|l|l|}
\hline Analyte & $\begin{array}{l}\text { Frequency } \\
\text { Out of } \\
\text { Range }\end{array}$ & $\begin{array}{l}\text { Mean } \\
\text { RPD (\%) }\end{array}$ & $\begin{array}{l}\text { Std. } \\
\text { Dev. }\end{array}$ & $\begin{array}{l}\text { Minimum } \\
\text { RPD (\%) }\end{array}$ & $\begin{array}{l}\text { Maximum } \\
\text { RPD (\%) }\end{array}$ \\
\hline Nonvolatile beta & $1 / 1$ & 26.3 & & 26.3 & 26.3 \\
\hline Potassium-40 & $0 / 1$ & -518 & & -518 & -518 \\
\hline Promethium-144 & $1 / 1$ & 177 & & 177 & 177 \\
\hline Promethium-146 & $0 / 1$ & 0 & & 0 & 0 \\
\hline Radium-228 & $0 / 1$ & 16.6 & & 16.6 & 16.6 \\
\hline Ruthenium-106 & $0 / 1$ & 0 & & 0 & 0 \\
\hline Sodium-22 & $0 / 1$ & 0 & & 0 & 0 \\
\hline Strontium-90 & $0 / 1$ & 6.21 & & 6.21 & 6.21 \\
\hline Tin-113 & $0 / 1$ & 0 & & 0 & 0 \\
\hline Tritium & $0 / 1$ & 15 & & 15 & 15 \\
\hline Yttrium-88 & $0 / 1$ & 0 & & 0 & 0 \\
\hline Zinc-65 & $0 / 1$ & 0 & & 0 & 0 \\
\hline Zirconium-95 & $0 / 1$ & 0 & & 0 & 0 \\
\hline
\end{tabular}

Table 3.17 Relative Percent Differences of Field Duplicates by GE

\begin{tabular}{|c|c|c|c|c|c|}
\hline Analyte & $\begin{array}{l}\text { Frequency } \\
\text { Out of } \\
\text { Range }\end{array}$ & $\begin{array}{l}\text { Mean } \\
\text { RPD (\%) }\end{array}$ & $\begin{array}{l}\text { Std. } \\
\text { Dev. }\end{array}$ & $\begin{array}{l}\text { Minimum } \\
\text { RPD (\%) }\end{array}$ & $\begin{array}{l}\text { Maximum } \\
\text { RPD }(\%)\end{array}$ \\
\hline \multicolumn{6}{|l|}{ Specified Analyses } \\
\hline Chloride & $0 / 2$ & 6.35 & 4.21 & 3.37 & 9.33 \\
\hline Cyanide & $0 / 2$ & 0 & 0 & 0 & 0 \\
\hline Hardness as $\mathrm{CACO} 3$ & $1 / 2$ & 33.7 & 37.8 & 6.9 & 60.4 \\
\hline Nitrate as nitrogen & $1 / 2$ & 14.2 & 15.9 & 2.91 & 25.4 \\
\hline Nitrate-nitrite as nitrogen & $1 / 2$ & 24.5 & 15.2 & 13.8 & 35.3 \\
\hline \multicolumn{6}{|l|}{ Metals (total recoverable) } \\
\hline Aluminum & $0 / 2$ & 2.73 & 0.17 & 2.61 & 2.85 \\
\hline Antimony & $0 / 2$ & 0 & 0 & 0 & 0 \\
\hline Arsenic & $0 / 2$ & 0 & 0 & 0 & 0 \\
\hline Barium & $0 / 2$ & 5.22 & 4.09 & 2.33 & 8.12 \\
\hline Beryllium & $0 / 2$ & 0 & 0 & 0 & 0 \\
\hline Cadmium & $0 / 2$ & 0 & 0 & 0 & 0 \\
\hline Calcium & $0 / 2$ & 6 & 8.49 & 0 & 12 \\
\hline Chromium & $1 / 2$ & 11.1 & 15.7 & 0 & 22.2 \\
\hline Cobalt & $0 / 2$ & 6.24 & 8.82 & 0 & 12.5 \\
\hline Copper & $0 / 2$ & 0 & 0 & 0 & 0 \\
\hline Iron & $0 / 2$ & 8.31 & 7.72 & 2.85 & 13.8 \\
\hline Lead & $1 / 2$ & 64.2 & 90.8 & 0 & 128 \\
\hline Magnesium & $0 / 2$ & 2.99 & 2.66 & 1.11 & 4.88 \\
\hline
\end{tabular}

Data Summary Report for the Annual Fourmile Branch and F- and H-Area Seeplines, Appendix IX Metals and Radionuclides, 1998 (WSRC-TR-98-00260) 
Table 3.17 Relative Percent Differences of Field Duplicates by GE (cont.)

\begin{tabular}{|l|l|l|l|l|l|}
\hline Analyte & $\begin{array}{l}\text { Frequency } \\
\text { Out of } \\
\text { Range }\end{array}$ & $\begin{array}{l}\text { Mean } \\
\text { RPD (\%) }\end{array}$ & $\begin{array}{l}\text { Std. } \\
\text { Dev. }\end{array}$ & $\begin{array}{l}\text { Minimum } \\
\text { RPD (\%) }\end{array}$ & $\begin{array}{l}\text { Maximum } \\
\text { RPD (\%) }\end{array}$ \\
\hline Manganese & $0 / 2$ & 0.718 & 0.581 & 0.307 & 1.13 \\
\hline Mercury & $0 / 2$ & 0 & 0 & 0 & 0 \\
\hline Nickel & $0 / 2$ & 0 & 0 & 0 & 0 \\
\hline Potassium & $0 / 2$ & 12.6 & 1.86 & 11.3 & 13.9 \\
\hline Selenium & $0 / 2$ & 0 & 0 & 0 & 0 \\
\hline Silver & $0 / 2$ & 0 & 0 & 0 & 0 \\
\hline Sodium & $0 / 2$ & 1.44 & 0.971 & 0.755 & 2.13 \\
\hline Thallium & $0 / 2$ & 0 & 0 & 0 & 0 \\
\hline Tin & $0 / 2$ & 0 & 0 & 0 & 0 \\
\hline Vanadium & $1 / 2$ & 19.3 & 15.4 & 8.4 & 30.2 \\
\hline Zinc & $1 / 2$ & 19.9 & 28.1 & 0 & 39.7 \\
\hline
\end{tabular}

Table 3.18 Relative Percent Differences of Field Duplicates by EP

\begin{tabular}{|l|l|l|l|l|l|l|}
\hline \multicolumn{2}{|l|}{$\begin{array}{l}\text { Frequency } \\
\text { Out of } \\
\text { Range }\end{array}$} & $\begin{array}{l}\text { Mean } \\
\text { RPD (\%) }\end{array}$ & $\begin{array}{l}\text { Std. } \\
\text { Dev. }\end{array}$ & $\begin{array}{l}\text { Minimum } \\
\text { RPD (\%) }\end{array}$ & $\begin{array}{l}\text { Maximum } \\
\text { RPD (\%) }\end{array}$ \\
\hline Radionuclides & \multicolumn{4}{l|}{} \\
\hline Actinium-228 & $0 / 2$ & 0 & 0 & 0 & 0 \\
\hline Antimony-124 & $0 / 2$ & 0 & 0 & 0 & 0 \\
\hline Antimony-125 & $0 / 2$ & 0 & 0 & 0 & 0 \\
\hline Barium-133 & $1 / 2$ & 149 & 210 & 0 & 298 \\
\hline Cerium-144 & $0 / 2$ & 0 & 0 & 0 & 0 \\
\hline Cesium-134 & $0 / 2$ & 0 & 0 & 0 & 0 \\
\hline Cesium-137 & $0 / 2$ & 0 & 0 & 0 & 0 \\
\hline Cobalt-57 & $0 / 2$ & 0 & 0 & 0 & 0 \\
\hline Cobalt-58 & $0 / 2$ & 0 & 0 & 0 & 0 \\
\hline Cobalt-60 & $0 / 2$ & 0 & 0 & 0 & 0 \\
\hline Europium-152 & $0 / 2$ & 0 & 0 & 0 & 0 \\
\hline Europium-154 & $0 / 2$ & 0 & 0 & 0 & 0 \\
\hline Europium-155 & $0 / 2$ & 0 & 0 & 0 & 0 \\
\hline Gross alpha & $2 / 2$ & 79.3 & 36.7 & 53.4 & 105 \\
\hline Lead-212 & $1 / 2$ & 47.9 & 67.8 & 0 & 95.9 \\
\hline Manganese-54 & $0 / 2$ & 0 & 0 & 0 & 0 \\
\hline Neptunium-239 & $0 / 2$ & 0 & 0 & 0 & 0 \\
\hline Nonvolatile beta & $1 / 2$ & 76.8 & 91.5 & 12.1 & 142 \\
\hline Potassium-40 & $0 / 2$ & 0 & 0 & 0 & 0 \\
\hline Promethium-144 & $0 / 2$ & 0 & 0 & 0 & 0 \\
\hline Promethium-146 & $0 / 2$ & 0 & 0 & 0 & 0 \\
\hline
\end{tabular}

Data Summary Report for the Annual Fourmile Branch and

F- and H-Area Seeplines, Appendix IX Metals and Radionuclides, 1998

(WSRC-TR-98-00260) 
Table 3.18 Relative Percent Differences of Field Duplicates by EP (cont.)

\begin{tabular}{|l|l|l|l|l|l|}
\hline Analyte & $\begin{array}{l}\text { Frequency } \\
\text { Out of } \\
\text { Range }\end{array}$ & $\begin{array}{l}\text { Mean } \\
\text { RPD (\%) }\end{array}$ & $\begin{array}{l}\text { Std. } \\
\text { Dev. }\end{array}$ & $\begin{array}{l}\text { Minimum } \\
\text { RPD (\%) }\end{array}$ & $\begin{array}{l}\text { Maximum } \\
\text { RPD (\%) }\end{array}$ \\
\hline Ruthenium-106 & $0 / 2$ & 0 & 0 & 0 & 0 \\
\hline Sodium-22 & $0 / 2$ & 0 & 0 & 0 & 0 \\
\hline Tin-113 & $0 / 2$ & 0 & 0 & 0 & 0 \\
\hline Tritium & $0 / 2$ & 4.57 & 0.666 & 4.1 & 5.04 \\
\hline Yttrium-88 & $0 / 2$ & 0 & 0 & 0 & 0 \\
\hline Zinc-65 & $0 / 2$ & 0 & 0 & 0 & 0 \\
\hline Zirconium-95 & $0 / 2$ & 0 & 0 & 0 & 0 \\
\hline
\end{tabular}

\subsubsection{Accuracy}

Accuracy is defined as the closeness of agreement between an observed value and an accepted reference value. Accuracy is especially important when the concentration of concern approaches the quantitation limit and/or the action limit. When the concentration is underestimated near the quantitation limit, the analyte may be present but reported as not detected. When the concentration is underestimated near the action limit, the analyte may be at a concentration that would require remediation, but the remediation would not be performed. When the concentration is overestimated near the quantitation limit, the analyte may not be present but reported as detected. When the concentration is overestimated near the action limit, the analyte may not be at a concentration that would require remediation, but the remediation would be performed. The sample types used to evaluate accuracy are performance evaluation studies (see Appendix B), LCS/BSs, surrogate spikes, and matrix spikes.

\section{Laboratory Control Samples}

LCSs monitor the performance of all steps in the analysis process, including sample preparation, and are used to identify problems with the analytical procedure. LCSs for inorganic analyses are DI water that is spiked with the target analyte, digested, and analyzed with the regular samples. LCSs for organic analyses are DI water that is spiked with selected target analytes, extracted, and analyzed with the regular samples. The LCS spiking solutions or solid LCSs are obtained from EPA or a third-party supplier or are prepared in the laboratory from chemicals from a different source than the calibration standards. The QC limits for radionuclide LCS are $80-120 \%$.

The following tables list the statistical information for the percent recovery for LCSs by analyte. The frequency out of range is the number of LCSs that had percent recoveries outside the acceptance limits compared to the total number analyzed; the other columns provide the mean percent recovery, standard deviation, and the minimum and maximum percent recoveries. 
The percent recovery is calculated as

$$
\% R=\frac{S R}{S A} \times 100,
$$

where $\% \mathrm{R}=$ percent recovery

$\mathrm{SR}=\mathrm{LCS}$ sample result

$\mathrm{SA}=$ spike-added result

Table 3.19 Laboratory Control Samples and Blank Spike Recoveries by GE

\begin{tabular}{|c|c|c|c|c|c|}
\hline Analyte & $\begin{array}{l}\text { Frequency } \\
\text { Out of } \\
\text { Range }\end{array}$ & $\begin{array}{l}\text { Mean } \\
\text { Recovery } \\
(\%)\end{array}$ & $\begin{array}{l}\text { Std. } \\
\text { Dev. }\end{array}$ & $\begin{array}{l}\text { Minimum } \\
\text { Recovery } \\
(\%)\end{array}$ & $\begin{array}{l}\text { Maximum } \\
\text { Recovery } \\
\text { (\%) }\end{array}$ \\
\hline \multicolumn{6}{|l|}{ Specified Analyses } \\
\hline Chloride & $0 / 4$ & 93.6 & 1.79 & 91.2 & 95 \\
\hline Cyanide & $0 / 2$ & 102 & 8.27 & 96.3 & 108 \\
\hline Hardness as CACO3 & $0 / 3$ & 97.7 & 0.577 & 97 & 98 \\
\hline Nitrate as nitrogen & $0 / 4$ & 99.5 & 4.53 & 92.8 & 103 \\
\hline Nitrate-nitrite as nitrogen & $0 / 4$ & 102 & 6.7 & 95 & 111 \\
\hline \multicolumn{6}{|l|}{ Metals (total recoverable) } \\
\hline Aluminum & $0 / 5$ & 100 & 1.57 & 99.1 & 103 \\
\hline Antimony & $0 / 5$ & 98.8 & 3.18 & 93.8 & 102 \\
\hline Arsenic & $0 / 5$ & 99 & 3.8 & 92.4 & 102 \\
\hline Barium & $0 / 5$ & 99.5 & 0.86 & 98.8 & 101 \\
\hline Beryllium & $0 / 5$ & 99.7 & 3.07 & 94.7 & 103 \\
\hline Cadmium & $0 / 5$ & 101 & 2.91 & 98.2 & 106 \\
\hline Calcium & $0 / 6$ & 99.4 & 3.86 & 92.3 & 104 \\
\hline Chromium & $0 / 5$ & 99.3 & 3.23 & 94.1 & 103 \\
\hline Cobalt & $0 / 5$ & 99.8 & 3.96 & 93 & 103 \\
\hline Coppèr & $0 / 5$ & 99 & 2.8 & 94.5 & 102 \\
\hline Iron & $0 / 5$ & 99.7 & 3.63 & 93.5 & 103 \\
\hline Lead & $0 / 5$ & 100 & 3.32 & 94.5 & 103 \\
\hline Magnesium & $0 / 5$ & 96.2 & 3.79 & 89.6 & 99.4 \\
\hline Manganese & $0 / 5$ & 97.8 & 3.65 & 91.7 & 101 \\
\hline Mercury & $0 / 4$ & 102 & 4.55 & 96.6 & 107 \\
\hline Nickel & $0 / 5$ & 101 & 2.44 & 98.2 & 105 \\
\hline Potassium & $0 / 5$ & 95.8 & 3.34 & 91.1 & 98.2 \\
\hline Selenium & $0 / 5$ & 96.5 & 4.01 & 89.6 & 99.6 \\
\hline Silver & $0 / 5$ & 103 & 3.34 & 97.8 & 107 \\
\hline Sodium & $0 / 5$ & 102 & 2.77 & 98 & 105 \\
\hline Thallium & $0 / 5$ & 100 & 2.38 & 96.6 & 103 \\
\hline Tin & $0 / 5$ & 98.7 & 3.85 & 92.2 & 102 \\
\hline
\end{tabular}

Data Summary Report for the Annual Fourmile Branch and

F- and H-Area Seeplines, Appendix IX Metals and Radionuclides, 1998

(WSRC-TR-98-00260) 
Table 3.19 Laboratory Control Samples and Blank Spike Recoveries by GE (cont.)

\begin{tabular}{|l|l|l|l|l|l|}
\hline & $\begin{array}{l}\text { Frequency } \\
\text { Out of } \\
\text { Range }\end{array}$ & $\begin{array}{l}\text { Mean } \\
\text { Recovery } \\
(\%)\end{array}$ & $\begin{array}{l}\text { Std. } \\
\text { Dev. }\end{array}$ & $\begin{array}{l}\text { Minimum } \\
\text { Recovery } \\
(\%)\end{array}$ & $\begin{array}{l}\text { Maximum } \\
\text { Recovery } \\
(\%)\end{array}$ \\
\hline Vanadium & $0 / 5$ & 99 & 2.92 & 94 & 101 \\
\hline Zinc & $0 / 5$ & 101 & 2.22 & 98.2 & 104 \\
\hline
\end{tabular}

Table 3.20 Laboratory Control Samples and Blank Spike Recoveries by Recra

\begin{tabular}{|c|c|c|c|c|c|}
\hline Analyte & $\begin{array}{l}\text { Frequency } \\
\text { Out of } \\
\text { Range }\end{array}$ & $\begin{array}{l}\text { Mean } \\
\text { Recovery } \\
(\%)\end{array}$ & $\begin{array}{l}\text { Std. } \\
\text { Dev. }\end{array}$ & $\begin{array}{l}\text { Minimum } \\
\text { Recovery } \\
(\%)\end{array}$ & $\begin{array}{l}\text { Maximum } \\
\text { Recovery } \\
(\%)\end{array}$ \\
\hline \multicolumn{6}{|l|}{ Specified Analyses } \\
\hline Chloride & $0 / 1$ & 94.6 & & 94.6 & 94.6 \\
\hline Cyanide & $0 / 2$ & 95.6 & 0.212 & 95.4 & 95.7 \\
\hline Hardness as CACO3 & $0 / 2$ & 102 & 0.707 & 101 & 102 \\
\hline Nitrate as nitrogen & $0 / 2$ & 106 & 1.41 & 105 & 107 \\
\hline Nitrate-nitrite as nitrogen & $0 / 2$ & 102 & 0 & 102 & 102 \\
\hline \multicolumn{6}{|c|}{ Metals (total recoverable) } \\
\hline Aluminum & $0 / 1$ & 103 & & 103 & 103 \\
\hline Antimony & $0 / 1$ & 98.4 & & 98.4 & 98.4 \\
\hline Arsenic & $0 / 1$ & 100 & & 100 & 100 \\
\hline Barium & $0 / 1$ & 98.7 & & 98.7 & 98.7 \\
\hline Beryllium & $0 / 1$ & 101 & & 101 & 101 \\
\hline Cadmium & $0 / 1$ & 101 & & 101 & 101 \\
\hline Calcium & $0 / 1$ & 103 & & 103 & 103 \\
\hline Chromium & $0 / 1$ & 99 & & 99 & 99 \\
\hline Cobalt & $0 / 1$ & 100 & & 100 & 100 \\
\hline Copper & $0 / 1$ & 99.8 & & 99.8 & 99.8 \\
\hline Iron & $0 / 1$ & 99.6 & & 99.6 & 99.6 \\
\hline Lead & $0 / 1$ & 101 & & 101 & 101 \\
\hline Magnesium & $0 / 1$ & 102 & & 102 & 102 \\
\hline Manganese & $0 / 1$ & 105 & & 105 & 105 \\
\hline Mercury & $0 / 1$ & 102 & & 102 & 102 \\
\hline Nickel & $0 / 1$ & 98.2 & & 98.2 & 98.2 \\
\hline Potassium & $0 / 1$ & 101 & & 101 & 101 \\
\hline Selenium & $0 / 1$ & 98.3 & & 98.3 & 98.3 \\
\hline Silver & $0 / 1$ & 100 & & 100 & 100 \\
\hline Sodium & $0 / 1$ & 100 & & 100 & 100 \\
\hline Thallium & $0 / 1$ & 100 & & 100 & 100 \\
\hline $\operatorname{Tin}$ & $0 / 1$ & 98.9 & & 98.9 & 98.9 \\
\hline Vanadium & $0 / 1$ & 102 & & 102 & 102 \\
\hline Zinc & $0 / 1$ & 99.2 & & 99.2 & 99.2 \\
\hline
\end{tabular}

Data Summary Report for the Annual Fourmile Branch and

F- and H-Area Seeplines, Appendix IX Metals and Radionuclides, 1998

(WSRC-TR-98-00260) 
Table 3.21 Laboratory Control Samples and Blank Spike Recoveries by EP

\begin{tabular}{|l|l|l|l|l|l|l|}
\hline \multicolumn{2}{|l|}{$\begin{array}{l}\text { Frequency } \\
\text { Out of } \\
\text { Range }\end{array}$} & $\begin{array}{l}\text { Mean } \\
\text { Recovery } \\
(\%)\end{array}$ & $\begin{array}{l}\text { Std. } \\
\text { Dev. }\end{array}$ & $\begin{array}{l}\text { Minimum } \\
\text { Recovery } \\
(\%)\end{array}$ & $\begin{array}{l}\text { Maximum } \\
\text { Recovery } \\
(\%)\end{array}$ \\
\hline Radionuclides & \multicolumn{4}{|l|}{} \\
\hline Americium-241 & $0 / 2$ & 100 & 11.3 & 92 & 108 \\
\hline Cesium-137 & $0 / 2$ & 98 & 5.66 & 94 & 102 \\
\hline Curium-243/244 & $0 / 2$ & 99.4 & 5.09 & 95.8 & 103 \\
\hline Gross alpha & $0 / 5$ & 104 & 5.83 & 99.4 & 113 \\
\hline Iodine-129 & $1 / 3$ & 100 & 18.8 & 78.8 & 114 \\
\hline Neptunium-237 & $0 / 2$ & 104 & 6.72 & 99.5 & 109 \\
\hline Nickel-63 & $0 / 3$ & 90.4 & 1.12 & 89.2 & 91.4 \\
\hline Nonvolatile beta & $0 / 5$ & 109 & 5.81 & 102 & 118 \\
\hline Radium-226 & $0 / 3$ & 101 & 10.2 & 90.2 & 110 \\
\hline Radium-228 & $0 / 3$ & 104 & 12.5 & 96 & 118 \\
\hline Tritium & $0 / 3$ & 98.8 & 3.94 & 94.4 & 102 \\
\hline Uranium-238 & $0 / 2$ & 95.2 & 8.27 & 89.3 & 101 \\
\hline
\end{tabular}

Table 3.22 Laboratory Control Samples and Blank Spike Recoveries by TNU

\begin{tabular}{|l|l|l|l|l|l|}
\hline & $\begin{array}{l}\text { Frequency } \\
\text { Out of } \\
\text { Range }\end{array}$ & $\begin{array}{l}\text { Mean } \\
\text { Recovery } \\
(\%)\end{array}$ & $\begin{array}{l}\text { Std. } \\
\text { Dev. }\end{array}$ & $\begin{array}{l}\text { Minimum } \\
\text { Recovery } \\
(\%)\end{array}$ & $\begin{array}{l}\text { Maximum } \\
\text { Recovery } \\
(\%)\end{array}$ \\
\hline Radionuclides & \multicolumn{5}{|l|}{} \\
\hline Cesium-137 & $0 / 1$ & 106 & & 106 & 106 \\
\hline Cobalt-60 & $0 / 1$ & 106 & & 105.55 & 105.55 \\
\hline Gross alpha & $0 / 1$ & 96.9 & & 96.89 & 96.89 \\
\hline Iodine-129 & $0 / 1$ & 87.6 & & 87.64 & 87.64 \\
\hline Nickel-63 & $1 / 1$ & 73.5 & & 73.45 & 73.45 \\
\hline Nonvolatile beta & $0 / 1$ & 101 & & 101.31 & 101.31 \\
\hline Radium-228 & $0 / 1$ & 109 & & 109.04 & 109.04 \\
\hline Strontium-90 & $0 / 1$ & 87.1 & & 87.07 & 87.07 \\
\hline Tritium & $0 / 1$ & 102 & & 102.45 & 102.45 \\
\hline
\end{tabular}

\section{Matrix Spikes}

Matrix spikes are used to evaluate the effect of the sample matrix on the analytical procedure. Matrix spikes for at least 5\% of the samples are prepared by adding a known quantity of the target analyte to the samples prior to sample preparation. All target analytes are spiked for the inorganic analyses. Selected target analytes are used in the spiking solution for the organic analyses. Results from the matrix spikes are used to evaluate the extent of matrix interference.

Data Summary Report for the Annual Fourmile Branch and F- and H-Area Seeplines, Appendix IX Metals and Radionuclides, 1998

(WSRC-TR-98-00260) 
The QC limits for matrix spikes are the same as those for LCSs except for inorganics, which have limits of 75-125\%. Matrix spikes are rejected if the concentration of the analyte in the sample is more than four times the amount of the spike.

The following tables list the percent recovery for the matrix spikes. The frequency out of range is the number of matrix spikes that had percent recoveries outside the acceptance limits compared to the total number analyzed; the other columns provide the mean percent recovery, standard deviation, and the minimum and maximum percent recoveries.

Table 3.23 Matrix Spike Recoveries by GE

\begin{tabular}{|c|c|c|c|c|c|}
\hline Analyte & $\begin{array}{l}\text { Frequency } \\
\text { Out of } \\
\text { Range }\end{array}$ & $\begin{array}{l}\text { Mean } \\
\text { Recovery } \\
\text { (\%) }\end{array}$ & $\begin{array}{l}\text { Std. } \\
\text { Dev. }\end{array}$ & $\begin{array}{l}\text { Minimum } \\
\text { Recovery } \\
\text { (\%) }\end{array}$ & $\begin{array}{l}\text { Maximum } \\
\text { Recovery } \\
(\%)\end{array}$ \\
\hline \multicolumn{6}{|l|}{ Specified Analyses } \\
\hline Chloride & $0 / 4$ & 99.7 & 5.54 & 93.2 & 106 \\
\hline Cyanide & $1 / 3$ & 89.2 & 15.4 & 73.2 & 104 \\
\hline Hardness as $\mathrm{CACO} 3$ & $0 / 3$ & 96 & 2.17 & 93.7 & 98 \\
\hline Nitrate as nitrogen & $0 / 4$ & 110 & 10.6 & 99.7 & 122 \\
\hline Nitrate-nitrite as nitrogen & $0 / 8$ & 102 & 10.9 & 83 & 117 \\
\hline \multicolumn{6}{|l|}{ Metals (total recoverable) } \\
\hline Aluminum & $2 / 6$ & 82.8 & 28.6 & 40.2 & 103 \\
\hline Antimony & $0 / 8$ & 96.1 & 7.33 & 84.4 & 104 \\
\hline Arsenic & $0 / 8$ & 98.3 & 5.35 & 89.4 & 105 \\
\hline Barium & $0 / 8$ & 99.5 & 2.14 & 96.9 & 103 \\
\hline Beryllium & $0 / 8$ & 98.9 & 3.58 & 92.5 & 103 \\
\hline Cadmium & $0 / 8$ & 99.7 & 3.23 & 94.5 & 103 \\
\hline Calcium & $0 / 10$ & 98.8 & 4.78 & 89.9 & 104 \\
\hline Chromium & $0 / 8$ & 98 & 3.72 & 91.2 & 102 \\
\hline Cobalt & $0 / 8$ & 98.6 & 4.93 & 90 & 104 \\
\hline Copper & $0 / 8$ & 99.5 & 3.29 & 93.8 & 104 \\
\hline Iron & $0 / 8$ & 101 & 8.47 & 87.6 & 113 \\
\hline Lead & $0 / 8$ & 98.5 & 4.16 & 91.6 & 104 \\
\hline Magnesium & $0 / 8$ & 95.3 & 3.95 & 88.6 & 99.7 \\
\hline Manganese & $0 / 8$ & 96.4 & 5.7 & 87.6 & 103 \\
\hline Mercury & $0 / 6$ & 103 & 1.83 & 101 & 105 \\
\hline Nickel & $0 / 8$ & 100 & 3.36 & 94.8 & 104 \\
\hline Potassium & $0 / 8$ & 95.9 & 3.81 & 90.2 & 100 \\
\hline Selenium & $0 / 8$ & 95.7 & 5 & 87 & 101 \\
\hline Silver & $0 / 8$ & 101 & 5.76 & 89.4 & 108 \\
\hline Sodium & $0 / 8$ & 97.1 & 5.74 & 87.7 & 104 \\
\hline Thallium & $0 / 8$ & 97.8 & 6.29 & 83.4 & 103 \\
\hline Tin & $0 / 8$ & 97.1 & 5.01 & 87.8 & 101 \\
\hline
\end{tabular}

Data Summary Report for the Annual Fourmile Branch and F- and H-Area Seeplines, Appendix IX Metals and Radionuclides, 1998 (WSRC-TR-98-00260) 
Table 3.23 Matrix Spike Recoveries by GE (cont.)

\begin{tabular}{|l|l|l|l|l|l|}
\hline Analyte & $\begin{array}{l}\text { Frequency } \\
\text { Out of } \\
\text { Range }\end{array}$ & $\begin{array}{l}\text { Mean } \\
\text { Recovery } \\
(\%)\end{array}$ & $\begin{array}{l}\text { Std. } \\
\text { Dev. }\end{array}$ & $\begin{array}{l}\text { Minimum } \\
\text { Recovery } \\
(\%)\end{array}$ & $\begin{array}{l}\text { Maximum } \\
\text { Recovery } \\
(\%)\end{array}$ \\
\hline Vanadium & $0 / 8$ & 97.8 & 3.5 & 91.4 & 101 \\
\hline Zinc & $0 / 8$ & 99.9 & 2.5 & 95.6 & 103 \\
\hline
\end{tabular}

Table 3.24 Matrix Spike Recoveries by Recra

\begin{tabular}{|c|c|c|c|c|c|}
\hline Analyte & $\begin{array}{l}\text { Frequency } \\
\text { Out of } \\
\text { Range }\end{array}$ & $\begin{array}{l}\text { Mean } \\
\text { Recovery } \\
(\%)\end{array}$ & $\begin{array}{l}\text { Std. } \\
\text { Dev. }\end{array}$ & $\begin{array}{l}\text { Minimum } \\
\text { Recovery } \\
(\%)\end{array}$ & $\begin{array}{l}\text { Maximum } \\
\text { Recovery } \\
\text { (\%) }\end{array}$ \\
\hline \multicolumn{6}{|l|}{ Specified Analyses } \\
\hline Cyanide & $0 / 2$ & 96.4 & 2.26 & 94.8 & 98 \\
\hline Hardness as CACO3 & $0 / 2$ & 100 & 0 & 100 & 100 \\
\hline \multicolumn{6}{|c|}{ Metals (total recoverable) } \\
\hline Mercury & $0 / 2$ & 99.3 & 0.99 & 98.6 & 100 \\
\hline
\end{tabular}

Table 3.25 Matrix Spike Recoveries by EP

\begin{tabular}{|l|l|l|l|l|l|}
\hline \multicolumn{2}{|l|}{$\begin{array}{l}\text { Frequency } \\
\text { Out of } \\
\text { Range }\end{array}$} & $\begin{array}{l}\text { Mean } \\
\text { Recovery } \\
(\%)\end{array}$ & $\begin{array}{l}\text { Std. } \\
\text { Dev. }\end{array}$ & $\begin{array}{l}\text { Minimum } \\
\text { Recovery } \\
(\%)\end{array}$ & $\begin{array}{l}\text { Maximum } \\
\text { Recovery } \\
(\%)\end{array}$ \\
\hline \multicolumn{5}{|l|}{ Radionuclides } & \multicolumn{5}{l|}{} \\
\hline Americium-241 & $0 / 2$ & 105 & 5.66 & 101 & 109 \\
\hline Cesium-137 & $0 / 2$ & 104 & 6.58 & 99.7 & 109 \\
\hline Curium-243/244 & $0 / 2$ & 97.8 & 4.53 & 94.6 & 101 \\
\hline Gross alpha & $0 / 5$ & 108 & 17.1 & 83.4 & 125 \\
\hline Iodine-129 & $0 / 3$ & 97.4 & 8.27 & 88.1 & 104 \\
\hline Neptunium-237 & $0 / 2$ & 97.4 & 3.68 & 94.8 & 100 \\
\hline Nickel-63 & $0 / 3$ & 92.2 & 0.666 & 91.8 & 93 \\
\hline Nonvolatile beta & $0 / 5$ & 111 & 8.48 & 98.8 & 120 \\
\hline Radium-226 & $0 / 3$ & 104 & 11.4 & 91.4 & 112 \\
\hline Radium-228 & $1 / 3$ & 119 & 15 & 102 & 131 \\
\hline Tritium & $0 / 2$ & 98.4 & 5.16 & 94.7 & 102 \\
\hline Uranium-238 & $0 / 2$ & 100 & 12.8 & 90.9 & 109 \\
\hline
\end{tabular}

\subsubsection{Contamination in Quality Control Samples}

\section{Field Blanks}

Field blanks are used to identify possible sources of contamination from the processing and shipping of samples. Field blanks consist of DI water or dry quartz sand sealed in sample bottles prior to sampling, opened in the field during sampling, resealed, and shipped to the laboratory with the samples. Positive results from field blanks can result from

Data Summary Report for the Annual Fourmile Branch and F- and H-Area Seeplines, Appendix IX Metals and Radionuclides, 1998

(WSRC-TR-98-00260) 
contaminated sample bottles, contaminated DI water or quartz sand, vapors in the air during sampling, contamination during shipping or analysis, or analytical bias. The results from all samples in the sample delivery group are evaluated to determine the cause of the contamination and the corrective action to be taken.

The following tables list the statistical information for the field blanks. The frequency detected is the number of field blanks analyzed for each analyte that had detectable concentrations compared to the total number analyzed. The other columns list the mean result, standard deviation, minimum and maximum results, and reporting unit. When the analyte is not detected, the mean and min./max. results are the ssEQLs for the field blanks.

Table 3.26 Analytes Detected in Field Blanks by GE

\begin{tabular}{|c|c|c|c|c|c|}
\hline Analyte & $\begin{array}{l}\text { Frequency } \\
\text { Detected }\end{array}$ & $\begin{array}{l}\text { Mean } \\
\text { Result }\end{array}$ & $\begin{array}{l}\text { Std. } \\
\text { Dev. }\end{array}$ & $\begin{array}{l}\text { Min./Max. } \\
\text { Result }\end{array}$ & Unit \\
\hline \multicolumn{6}{|c|}{ Specified Analyses } \\
\hline Cyanide & $0 / 3$ & 10 & 0 & $10 / 10$ & $\mathrm{ug} / \mathrm{L}$ \\
\hline \multicolumn{6}{|c|}{ Metals (total recoverable) } \\
\hline Aluminum & $2 / 2$ & 42.8 & 0.566 & $42.4 / 43.2$ & $\mathrm{ug} / \mathrm{L}$ \\
\hline Antimony & $2 / 2$ & 2.11 & 0.304 & $1.89 / 2.32$ & $\mathrm{ug} / \mathrm{L}$ \\
\hline Arsenic & $1 / 2$ & 4.41 & 0.841 & $3.81 / 5$ & $\mathrm{ug} / \mathrm{L}$ \\
\hline Barium & $1 / 2$ & 2.8 & 3.11 & $0.597 / 5$ & $\mathrm{ug} / \mathrm{L}$ \\
\hline Beryllium & $0 / 2$ & 5 & 0 & $5 / 5$ & $\mathrm{ug} / \mathrm{L}$ \\
\hline Cadmium & $0 / 2$ & 5 & 0 & $5 / 5$ & $\mathrm{ug} / \mathrm{L}$ \\
\hline Calcium & $0 / 2$ & 17.1 & 0.707 & $16.6 / 17.6$ & $\mathrm{ug} / \mathrm{L}$ \\
\hline Chromium & $0 / 2$ & 5 & 0 & $5 / 5$ & $\mathrm{ug} / \mathrm{L}$ \\
\hline Cobalt & $0 / 2$ & 5 & 0 & $5 / 5$ & $\mathrm{ug} / \mathrm{L}$ \\
\hline Copper & $0 / 2$ & 5 & 0 & $5 / 5$ & $\mathrm{ug} / \mathrm{L}$ \\
\hline Iron & $0 / 2$ & 50 & 0 & $50 / 50$ & $\mathrm{ug} / \mathrm{L}$ \\
\hline Lead & $0 / 2$ & 3.13 & 2.65 & $1.25 / 5$ & $\mathrm{ug} / \mathrm{L}$ \\
\hline Magnesium & $0 / 2$ & 10 & 0 & $10 / 10$ & $\mathrm{ug} / \mathrm{L}$ \\
\hline Manganese & $0 / 2$ & 10 & 0 & $10 / 10$ & $\mathrm{ug} / \mathrm{L}$ \\
\hline Mercury & $0 / 2$ & 0.2 & 0 & $0.2 / 0.2$ & $\mathrm{ug} / \mathrm{L}$ \\
\hline Nickel & $0 / 2$ & 5 & 0 & $5 / 5$ & $\mathrm{ug} / \mathrm{L}$ \\
\hline Potassium & $0 / 2$ & 15 & 3.11 & $12.8 / 17.2$ & $\mathrm{ug} / \mathrm{L}$ \\
\hline Selenium & $0 / 2$ & 5 & 0 & $5 / 5$ & ug/L \\
\hline Silver & $0 / 2$ & 2.57 & 0.0212 & $2.55 / 2.58$ & $\mathrm{ug} / \mathrm{L}$ \\
\hline Sodium & $0 / 2$ & 39.6 & 2.55 & $37.8 / 41.4$ & $\mathrm{ug} / \mathrm{L}$ \\
\hline Thallium & $0 / 2$ & 10 & 0 & $10 / 10$ & $\mathrm{ug} / \mathrm{L}$ \\
\hline Tin & $0 / 2$ & 10 & 0 & $10 / 10$ & $\mathrm{ug} / \mathrm{L}$ \\
\hline Vanadium & $0 / 2$ & 5 & 0 & $5 / 5$ & $\mathrm{ug} / \mathrm{L}$ \\
\hline Zinc & $0 / 2$ & 2.46 & 0.0424 & $2.43 / 2.49$ & $\mathrm{ug} / \mathrm{L}$ \\
\hline
\end{tabular}

Data Summary Report for the Annual Fourmile Branch and F- and H-Area Seeplines, Appendix IX Metals and Radionuclides, 1998 (WSRC-TR-98-00260) 
Table 3.27 Analytes Detected in Field Blanks by EP

\begin{tabular}{|c|c|c|c|c|c|}
\hline Analyte & $\begin{array}{l}\text { Frequency } \\
\text { Detected }\end{array}$ & $\begin{array}{l}\text { Mean } \\
\text { Result }\end{array}$ & $\begin{array}{l}\text { Std. } \\
\text { Dev. }\end{array}$ & $\begin{array}{l}\text { Min.Max. } \\
\text { Result }\end{array}$ & Unit \\
\hline \multicolumn{6}{|l|}{ Radionuclides } \\
\hline Actinium-228 & $0 / 2$ & 7.24 & 6.46 & $2.67 / 11.8$ & $\mathrm{pCi} / \mathrm{L}$ \\
\hline Antimony-124 & $0 / 2$ & 1.45 & 0.191 & $1.31 / 1.58$ & $\mathrm{pCi} / \mathrm{L}$ \\
\hline Antimony-125 & $0 / 2$ & -4.3 & 1.49 & $-5.35 /-3.24$ & $\mathrm{pCi} / \mathrm{L}$ \\
\hline Barium-133 & $0 / 2$ & -2.3 & 1.13 & $-3.1 /-1.5$ & $\mathrm{pCi} / \mathrm{L}$ \\
\hline Cerium-144 & $0 / 2$ & 7.26 & 21.3 & $-7.78 / 22.3$ & $\mathrm{pCi} / \mathrm{L}$ \\
\hline Cesium-134 & $0 / 2$ & -0.35 & 0.359 & $-0.604 /-0.0963$ & $\mathrm{pCi} / \mathrm{L}$ \\
\hline Cesium-137 & $0 / 2$ & -0.932 & 0.139 & $-1.03 /-0.834$ & $\mathrm{pCi} / \mathrm{L}$ \\
\hline Cobalt-57 & $0 / 2$ & -0.551 & 0.79 & $-1.11 / 0.00711$ & $\mathrm{pCi} / \mathrm{L}$ \\
\hline Cobalt-58 & $0 / 2$ & 1.68 & 1.99 & $0.27 / 3.08$ & $\mathrm{pCi} / \mathrm{L}$ \\
\hline Cobalt- 60 & $0 / 2$ & 0.365 & 0.912 & $-0.28 / 1.01$ & $\mathrm{pCi} / \mathrm{L}$ \\
\hline Europium-152 & $0 / 2$ & -0.39 & 3.25 & $-2.69 / 1.91$ & $\mathrm{pCi} / \mathrm{L}$ \\
\hline Europium-154 & $0 / 2$ & 1.73 & 3.51 & $-0.751 / 4.21$ & $\mathrm{pCi} / \mathrm{L}$ \\
\hline Europium-155 & $0 / 2$ & 2.53 & 4.61 & $-0.724 / 5.79$ & $\mathrm{pCi} / \mathrm{L}$ \\
\hline Gross alpha & $0 / 2$ & 0.0639 & 0.192 & $-0.0722 / 0.2$ & $\mathrm{pCi} / \mathrm{L}$ \\
\hline Lead-212 & $0 / 2$ & 3.83 & 2.84 & $1.82 / 5.83$ & $\mathrm{pCi} / \mathrm{L}$ \\
\hline Manganese-54 & $0 / 2$ & 0.285 & 2.79 & $-1.69 / 2.26$ & $\mathrm{pCi} / \mathrm{L}$ \\
\hline Neptunium-239 & $0 / 2$ & -1.42 & 6.71 & $-6.16 / 3.33$ & $\mathrm{pCi} / \mathrm{L}$ \\
\hline Nonvolatile beta & $0 / 2$ & 0.181 & 0.566 & $-0.219 / 0.581$ & $\mathrm{pCi} / \mathrm{L}$ \\
\hline Potassium- 40 & $0 / 2$ & 30.6 & 26.6 & $11.8 / 49.4$ & $\mathrm{pCi} / \mathrm{L}$ \\
\hline Promethium-144 & $0 / 2$ & 1.97 & 0.686 & $1.48 / 2.45$ & $\mathrm{pCi} / \mathrm{L}$ \\
\hline Promethium-146 & $0 / 2$ & -0.756 & 0.387 & $-1.03 /-0.482$ & $\mathrm{pCi} / \mathrm{L}$ \\
\hline Ruthenium-106 & $0 / 2$ & 17.4 & 21 & $2.53 / 32.2$ & $\mathrm{pCi} / \mathrm{L}$ \\
\hline Sodium-22 & $0 / 2$ & 0.363 & 1.62 & $-0.784 / 1.51$ & $\mathrm{pCi} / \mathrm{L}$ \\
\hline Tin-113 & $0 / 2$ & 2.66 & 2.57 & $0.846 / 4.48$ & $\mathrm{pCi} / \mathrm{L}$ \\
\hline Yttrium-88 & $0 / 2$ & -1.25 & 2.42 & $-2.96 / 0.461$ & $\mathrm{pCi} / \mathrm{L}$ \\
\hline Zinc-65 & $0 / 2$ & 0.238 & 0.818 & $-0.341 / 0.816$ & $\mathrm{pCi} / \mathrm{L}$ \\
\hline Zirconium-95 & $0 / 2$ & 3.63 & 2.69 & $1.72 / 5.53$ & $\mathrm{pCi} / \mathrm{L}$ \\
\hline
\end{tabular}

\section{Method Blanks}

Method blanks are used to determine the existence and magnitude of contamination resulting from the analytical process. Method blanks are analyte-free matrices (DI water for aqueous samples and sodium sulfate for solid samples) that are prepared in the same manner and at the same time as the samples. When method blanks have detectable concentrations of analytes, the laboratory must determine the cause and take corrective action to eliminate the contamination.

The following tables list the statistical information for the method blanks. The frequency detected column gives the number of method blanks analyzed for each analyte that had detectable concentrations compared to the total number analyzed. The other columns list

Data Summary Report for the Annual Fourmile Branch and

F- and H-Area Seeplines, Appendix IX Metals and Radionuclides, 1998

(WSRC-TR-98-00260) 
the mean result, standard deviation, minimum and maximum results, and reporting unit. When the the analyte is not detected, the mean and minimum and maximum results are the ssEQLs for the method blanks.

Table 3.28 Analytes Detected in Method Blanks by GE

\begin{tabular}{|c|c|c|c|c|c|}
\hline Analyte & $\begin{array}{l}\text { Frequency } \\
\text { Detected }\end{array}$ & $\begin{array}{l}\text { Mean } \\
\text { Result }\end{array}$ & $\begin{array}{l}\text { Std. } \\
\text { Dev. }\end{array}$ & $\begin{array}{l}\text { Min Max. } \\
\text { Result }\end{array}$ & Unit \\
\hline \multicolumn{6}{|l|}{ Specified Analyses } \\
\hline Chloride & $3 / 4$ & 60 & 40.7 & $23 / 100$ & $\mathrm{ug} / \mathrm{L}$ \\
\hline Cyanide & $0 / 2$ & 10 & 0 & $10 / 10$ & $\mathrm{ug} / \mathrm{L}$ \\
\hline Hardness as CACO3 & $0 / 3$ & 2000 & 0 & $2000 / 2000$ & $\mathrm{ug} / \mathrm{L}$ \\
\hline Nitrate as nitrogen & $3 / 4$ & 21 & 19.8 & $7 / 50$ & $\mathrm{ug} / \mathrm{L}$ \\
\hline Nitrate-nitrite as nitrogen & $1 / 4$ & 40 & 20 & $10 / 50$ & $\mathrm{ug} / \mathrm{L}$ \\
\hline \multicolumn{6}{|l|}{ Metals (total recoverable) } \\
\hline Aluminum & $1 / 5$ & 49.1 & 1.97 & $45.6 / 50$ & $\mathrm{ug} / \mathrm{L}$ \\
\hline Antimony & $0 / 5$ & 10 & 0 & $10 / 10$ & $\mathrm{ug} / \mathrm{L}$ \\
\hline Arsenic & $0 / 5$ & 5 & 0 & $5 / 5$ & $\mathrm{ug} / \mathrm{L}$ \\
\hline Barium & $0 / 5$ & 5 & 0 & $5 / 5$ & $\mathrm{ug} / \mathrm{L}$ \\
\hline Beryllium & $0 / 5$ & 5 & 0 & $5 / 5$ & $\mathrm{ug} / \mathrm{L}$ \\
\hline Cadmium & $0 / 5$ & 5 & 0 & $5 / 5$ & $\mathrm{ug} / \mathrm{L}$ \\
\hline Calcium & $5 / 6$ & 81.8 & 91.1 & $18.6 / 257$ & $\mathrm{ug} / \mathrm{L}$ \\
\hline Chromium & $0 / 5$ & 5 & 0 & $5 / 5$ & $\mathrm{ug} / \mathrm{L}$ \\
\hline Cobalt & $0 / 5$ & 5 & 0 & $5 / 5$ & $\mathrm{ug} / \mathrm{L}$ \\
\hline Copper & $0 / 5$ & 5 & 0 & $5 / 5$ & $\mathrm{ug} / \mathrm{L}$ \\
\hline Iron & $1 / 5$ & 46.7 & 7.38 & $33.5 / 50$ & $\mathrm{ug} / \mathrm{L}$ \\
\hline Lead & $2 / 5$ & 3.56 & 2.01 & $0.857 / 5$ & $\mathrm{ug} / \mathrm{L}$ \\
\hline Magnesium & $2 / 5$ & 7.73 & 3.11 & $4.12 / 10$ & $\mathrm{ug} / \mathrm{L}$ \\
\hline Manganese & $2 / 5$ & 6.59 & 4.68 & $0.933 / 10$ & $\mathrm{ug} / \mathrm{L}$ \\
\hline Mercury & $1 / 4$ & 0.177 & 0.047 & $0.106 / 0.2$ & $\mathrm{ug} / \mathrm{L}$ \\
\hline Nickel & $0 / 5$ & 5 & 0 & $5 / 5$ & $\mathrm{ug} / \mathrm{L}$ \\
\hline Potassium & $2 / 5$ & 64.2 & 49 & $10.3 / 100$ & $\mathrm{ug} / \mathrm{L}$ \\
\hline Selenium & $0 / 5$ & 5 & 0 & $5 / 5$ & $\mathrm{ug} / \mathrm{L}$ \\
\hline Silver & $3 / 5$ & 3.03 & 1.96 & $1.03 / 5$ & $\mathrm{ug} / \mathrm{L}$ \\
\hline Sodium & $4 / 5$ & 55 & 26.2 & $32.8 / 100$ & $\mathrm{ug} / \mathrm{L}$ \\
\hline Thallium & $0 / 5$ & 10 & 0 & $10 / 10$ & $\mathrm{ug} / \mathrm{L}$ \\
\hline Tin & $0 / 5$ & 10 & 0 & $10 / 10$ & $\mathrm{ug} / \mathrm{L}$ \\
\hline Vanadium & $0 / 5$ & 5 & 0 & $5 / 5$ & $\mathrm{ug} / \mathrm{L}$ \\
\hline Zinc & $3 / 5$ & 3.09 & 1.83 & $1.02 / 5$ & $\mathrm{ug} / \mathrm{L}$ \\
\hline
\end{tabular}

Data Summary Report for the Annual Fourmile Branch and F- and H-Area Seeplines, Appendix IX Metals and Radionuclides, 1998 (WSRC-TR-98-00260) 
Table 3.29 Analytes Detected in Method Blanks by Recra

\begin{tabular}{|c|c|c|c|c|c|}
\hline Analyte & $\begin{array}{l}\text { Frequency } \\
\text { Detected }\end{array}$ & $\begin{array}{l}\text { Mean } \\
\text { Result }\end{array}$ & $\begin{array}{l}\text { Std. } \\
\text { Dev. }\end{array}$ & $\begin{array}{l}\text { Min_/Max. } \\
\text { Result }\end{array}$ & Unit \\
\hline \multicolumn{6}{|l|}{ Specified Analyses } \\
\hline Chloride & $0 / 1$ & 210 & & $210 / 210$ & $\mathrm{ug} / \mathrm{L}$ \\
\hline Cyanide & $0 / 1$ & 15.2 & & $15.2 / 15.2$ & $\mathrm{ug} / \mathrm{L}$ \\
\hline Hardness as CACO3 & $0 / 1$ & 9000 & & $9000 / 9000$ & $\mathrm{ug} / \mathrm{L}$ \\
\hline Nitrate as nitrogen & $0 / 1$ & 20 & & $20 / 20$ & $\mathrm{ug} / \mathrm{L}$ \\
\hline Nitrate-nitrite as nitrogen & $0 / 1$ & 40 & & $40 / 40$ & $\mathrm{ug} / \mathrm{L}$ \\
\hline \multicolumn{6}{|l|}{ Metals (total recoverable) } \\
\hline Aluminum & $0 / 1$ & 146 & & $146 / 146$ & $\mathrm{ug} / \mathrm{L}$ \\
\hline Antimony & $0 / 1$ & 27 & & $27 / 27$ & $\mathrm{ug} / \mathrm{L}$ \\
\hline Arsenic & $0 / 1$ & 40 & & $40 / 40$ & $\mathrm{ug} / \mathrm{L}$ \\
\hline Barium & $1 / 1$ & 0.69 & & $0.69 / 0.69$ & $\mathrm{ug} / \mathrm{L}$ \\
\hline Beryllium & $0 / 1$ & 1.6 & & $1.6 / 1.6$ & $\mathrm{ug} / \mathrm{L}$ \\
\hline Cadmium & $0 / 1$ & 4.7 & & $4.7 / 4.7$ & $\mathrm{ug} / \mathrm{L}$ \\
\hline Calcium & $0 / 1$ & 471 & & $471 / 471$ & $\mathrm{ug} / \mathrm{L}$ \\
\hline Chromium & $0 / 1$ & 7 & & $7 / 7$ & $\mathrm{ug} / \mathrm{L}$ \\
\hline Cobalt & $0 / 1$ & 4.5 & & $4.5 / 4.5$ & $\mathrm{ug} / \mathrm{L}$ \\
\hline Copper & $0 / 1$ & 15 & & $15 / 15$ & $\mathrm{ug} / \mathrm{L}$ \\
\hline Iron & $0 / 1$ & 74 & & $74 / 74$ & $\mathrm{ug} / \mathrm{L}$ \\
\hline Lead & $0 / 1$ & 47 & & $47 / 47$ & $\mathrm{ug} / \mathrm{L}$ \\
\hline Magnesium & $1 / 1$ & 11.9 & & $11.9 / 11.9$ & $\mathrm{ug} / \mathrm{L}$ \\
\hline Manganese & $0 / 1$ & 7.8 & & $7.8 / 7.8$ & $\mathrm{ug} / \mathrm{L}$ \\
\hline Mercury & $0 / 2$ & 0.7 & 0 & $0.7 / 0.7$ & $\mathrm{ug} / \mathrm{L}$ \\
\hline Nickel & $0 / 1$ & 26 & & $26 / 26$ & $\mathrm{ug} / \mathrm{L}$ \\
\hline Potassium & $0 / 1$ & 187 & & $187 / 187$ & ug/L \\
\hline Selenium & $0 / 1$ & 66 & & $66 / 66$ & $\mathrm{ug} / \mathrm{L}$ \\
\hline Silver & $0 / 1$ & 5 & & $5 / 5$ & $\mathrm{ug} / \mathrm{L}$ \\
\hline Sodium & $1 / 1$ & 60.2 & & $60.2 / 60.2$ & $\mathrm{ug} / \mathrm{L}$ \\
\hline Thallium & $0 / 1$ & 55 & & $55 / 55$ & $\mathrm{ug} / \mathrm{L}$ \\
\hline Tin & $0 / 1$ & 70 & & $70 / 70$ & $\mathrm{ug} / \mathrm{L}$ \\
\hline Vanadium & $0 / 1$ & 6.9 & & $6.9 / 6.9$ & $\mathrm{ug} / \mathrm{L}$ \\
\hline Zinc & $0 / 1$ & 53 & & $53 / 53$ & $\mathrm{ug} / \mathrm{L}$ \\
\hline
\end{tabular}

Table 3.30 Analytes Detected in Method Blanks by EP

\begin{tabular}{|l|l|l|l|l|l|}
\hline Analyte & $\begin{array}{l}\text { Frequency } \\
\text { Detected }\end{array}$ & $\begin{array}{l}\text { Mean } \\
\text { Result }\end{array}$ & $\begin{array}{l}\text { Std. } \\
\text { Dev. }\end{array}$ & $\begin{array}{l}\text { Min } / \text { Max. } \\
\text { Result }\end{array}$ & Unit \\
\hline \multicolumn{5}{|l|}{} \\
\hline Radionuclides & $0 / 2$ & 3.26 & 1.19 & $2.42 / 4.1$ & $\mathrm{pCi} / \mathrm{L}$ \\
\hline Actinium-228 & $1 / 2$ & 0.0166 & 0.00247 & $0.0148 / 0.0183$ & $\mathrm{pCi} / \mathrm{L}$ \\
\hline
\end{tabular}

Data Summary Report for the Annual Fourmile Branch and

F- and H-Area Seeplines, Appendix IX Metals and Radionuclides, 1998

(WSRC-TR-98-00260) 
Table 3.30 Analytes Detected in Method Blanks by EP (cont.)

\begin{tabular}{|c|c|c|c|c|c|}
\hline Analyte & $\begin{array}{l}\text { Frequency } \\
\text { Detected }\end{array}$ & $\begin{array}{l}\text { Mean } \\
\text { Result }\end{array}$ & $\begin{array}{l}\text { Std. } \\
\text { Dev. }\end{array}$ & $\begin{array}{l}\text { Min. } / \text { Max. } \\
\text { Result }\end{array}$ & Unit \\
\hline Antimony-124 & $0 / 2$ & 0.684 & 0.674 & $0.207 / 1.16$ & $\mathrm{pCi} / \mathrm{L}$ \\
\hline Antimony-125 & $0 / 2$ & 0.121 & 0.861 & $-0.488 / 0.73$ & $\mathrm{pCi} / \mathrm{L}$ \\
\hline Barium-133 & $0 / 2$ & -0.0485 & 0.907 & $-0.69 / 0.593$ & $\mathrm{pCi} / \mathrm{L}$ \\
\hline Cerium-144 & $0 / 2$ & -0.21 & 3.69 & $-2.82 / 2.4$ & $\mathrm{pCi} / \mathrm{L}$ \\
\hline Cesium-134 & $0 / 2$ & -0.027 & 1.18 & $-0.863 / 0.809$ & $\mathrm{pCi} / \mathrm{L}$ \\
\hline Cesium-137 & $0 / 2$ & -1.19 & 0.844 & $-1.79 /-0.597$ & $\mathrm{pCi} / \mathrm{L}$ \\
\hline Cobalt-57 & $0 / 2$ & -0.298 & 0.433 & $-0.604 / 0.00801$ & $\mathrm{pCi} / \mathrm{L}$ \\
\hline Cobalt-58 & $0 / 2$ & -0.381 & 0.218 & $-0.535 /-0.226$ & $\mathrm{pCi} / \mathrm{L}$ \\
\hline Cobalt-60 & $0 / 2$ & -0.065 & 0.851 & $-0.667 / 0.537$ & $\mathrm{pCi} / \mathrm{L}$ \\
\hline Curium-242 & $0 / 2$ & 0.0074 & 0.0105 & $0 / 0.0148$ & $\mathrm{pCi} / \mathrm{L}$ \\
\hline Curium-243/244 & $0 / 2$ & 0.0085 & 0.012 & $0 / 0.017$ & $\mathrm{pCi} / \mathrm{L}$ \\
\hline Curium-245/246 & $0 / 2$ & 0.00831 & 0.00136 & $0.00734 / 0.00927$ & $\mathrm{pCi} / \mathrm{L}$ \\
\hline Europium-152 & $0 / 2$ & 3.76 & 0.969 & $3.07 / 4.44$ & $\mathrm{pCi} / \mathrm{L}$ \\
\hline Europium-154 & $0 / 2$ & -1.39 & 1.38 & $-2.36 /-0.415$ & $\mathrm{pCi} / \mathrm{L}$ \\
\hline Europium-155 & $0 / 2$ & 0.65 & 2.35 & $-1.01 / 2.31$ & $\mathrm{pCi} / \mathrm{L}$ \\
\hline Gross alpha & $0 / 5$ & 0.00566 & 0.128 & $-0.18 / 0.135$ & $\mathrm{pCi} / \mathrm{L}$ \\
\hline Iodine-129 & $0 / 3$ & 0.284 & 0.0925 & $0.218 / 0.39$ & $\mathrm{pCi} / \mathrm{L}$ \\
\hline Lead-212 & $1 / 2$ & 3.44 & 3.68 & $0.839 / 6.05$ & $\mathrm{pCi} / \mathrm{L}$ \\
\hline Manganese-54 & $0 / 2$ & 0.107 & 0.371 & $-0.155 / 0.369$ & $\mathrm{pCi} / \mathrm{L}$ \\
\hline Neptunium-237 & $0 / 2$ & -0.00111 & 0.00873 & $-0.00728 / 0.00507$ & $\mathrm{pCi} / \mathrm{L}$ \\
\hline Neptunium-239 & $0 / 2$ & -0.852 & 0.747 & $-1.38 /-0.324$ & $\mathrm{pCi} / \mathrm{L}$ \\
\hline Nickel-63 & $0 / 3$ & -1.81 & 20.2 & $-17.4 / 21$ & $\mathrm{pCi} / \mathrm{L}$ \\
\hline Nonvolatile beta & $0 / 5$ & -0.0378 & 0.195 & $-0.289 / 0.248$ & $\mathrm{pCi} / \mathrm{L}$ \\
\hline Potassium- 40 & $0 / 2$ & 17.2 & 0.566 & $16.8 / 17.6$ & $\mathrm{pCi} / \mathrm{L}$ \\
\hline Promethium-144 & $0 / 2$ & 0.441 & 1.46 & $-0.589 / 1.47$ & $\mathrm{pCi} / \mathrm{L}$ \\
\hline Promethium-146 & $0 / 2$ & -0.595 & 0.431 & $-0.9 /-0.29$ & $\mathrm{pCi} / \mathrm{L}$ \\
\hline Radium-226 & $0 / 3$ & 0.204 & 0.0958 & $0.13 / 0.312$ & $\mathrm{pCi} / \mathrm{L}$ \\
\hline Radium-228 & $0 / 3$ & -0.386 & 0.656 & $-1.14 / 0.0498$ & $\mathrm{pCi} / \mathrm{L}$ \\
\hline Ruthenium-106 & $0 / 2$ & 1.17 & 5.13 & $-2.46 / 4.8$ & $\mathrm{pCi} / \mathrm{L}$ \\
\hline Sodium-22 & $0 / 2$ & -0.492 & 0.482 & $-0.832 /-0.151$ & $\mathrm{pCi} / \mathrm{L}$ \\
\hline Tin-113 & $0 / 2$ & 0.57 & 1.2 & $-0.28 / 1.42$ & $\mathrm{pCi} / \mathrm{L}$ \\
\hline Tritium & $0 / 3$ & -0.0507 & 0.0731 & $-0.121 / 0.0249$ & $\mathrm{pCi} / \mathrm{mL}$ \\
\hline Uranium-233/234 & $0 / 2$ & 0.0233 & 0.00375 & $0.0206 / 0.0259$ & $\mathrm{pCi} / \mathrm{L}$ \\
\hline Uranium-235 & $0 / 2$ & 0.011 & 0.00224 & $0.00943 / 0.0126$ & $\mathrm{pCi} / \mathrm{L}$ \\
\hline Uranium-238 & $0 / 2$ & 0.00709 & 0.00327 & $0.00478 / 0.0094$ & $\mathrm{pCi} / \mathrm{L}$ \\
\hline Yttrium-88 & $0 / 2$ & 0.0686 & 0.148 & $-0.0358 / 0.173$ & $\mathrm{pCi} / \mathrm{L}$ \\
\hline Zinc-65 & $0 / 2$ & -1.02 & 0.56 & $-1.42 /-0.628$ & $\mathrm{pCi} / \mathrm{L}$ \\
\hline Zirconium-95 & $0 / 2$ & 0.585 & 0.899 & $-0.0507 / 1.22$ & $\mathrm{pCi} / \mathrm{L}$ \\
\hline
\end{tabular}

Data Summary Report for the Annual Fourmile Branch and F- and H-Area Seeplines, Appendix IX Metals and Radionuclides, 1998 (WSRC-TR-98-00260) 
Table 3.31 Analytes Detected in Method Blanks by TNU

\begin{tabular}{|l|l|l|l|l|l|}
\hline Analyte & $\begin{array}{l}\text { Frequency } \\
\text { Detected }\end{array}$ & $\begin{array}{l}\text { Mean } \\
\text { Result }\end{array}$ & $\begin{array}{l}\text { Std. } \\
\text { Dev. }\end{array}$ & $\begin{array}{l}\text { Min } / \text { Max. } \\
\text { Result }\end{array}$ & Unit \\
\hline Radionuclides & \multicolumn{5}{|l|}{} \\
\hline Cesium-137 & $0 / 1$ & 1.46 & & $1.46 / 1.46$ & $\mathrm{pCi} / \mathrm{L}$ \\
\hline Cobalt-60 & $0 / 1$ & -0.25 & & $-0.25 /-0.25$ & $\mathrm{pCi} / \mathrm{L}$ \\
\hline Gross alpha & $0 / 1$ & -0.07 & & $-0.07 /-0.07$ & $\mathrm{pCi} / \mathrm{L}$ \\
\hline Iodine-129 & $0 / 1$ & 0.14 & & $0.14 / 0.14$ & $\mathrm{pCi} / \mathrm{L}$ \\
\hline Nickel-63 & $0 / 1$ & -1.86 & & $-1.86 /-1.86$ & $\mathrm{pCi} / \mathrm{L}$ \\
\hline Nonvolatile beta & $0 / 1$ & -0.75 & & $-0.75 /-0.75$ & $\mathrm{pCi} / \mathrm{L}$ \\
\hline Radium-228 & $0 / 1$ & 0.82 & & $0.82 / 0.82$ & $\mathrm{pCi} / \mathrm{L}$ \\
\hline Strontium-90 & $0 / 1$ & 0.47 & & $0.47 / 0.47$ & $\mathrm{pCi} / \mathrm{L}$ \\
\hline Tritium & $0 / 1$ & -0.2 & & $-0.2 /-0.2$ & $\mathrm{pCi} / \mathrm{mL}$ \\
\hline
\end{tabular}

\section{Trip Blanks}

Trip blanks are used to detect contamination by volatile substances during shipping, primarily due to the breaking of the seal on the vial caused by depressurization during air transport. Trip blanks are analyzed for VOAs only. Trip blanks are prepared by the EPD/EMS laboratory for groundwater studies and by the analytical laboratory for other studies. If prepared by the analytical laboratory, trip blanks are shipped to EPD/EMS with the sample containers. The blanks are prepared by adding preservative to a $40-\mathrm{mL}$ vial, filling it completely with DI water (no air bubbles), and sealing the top with a Teflonlined septum cap. If a trip blank is found to be contaminated, the results from all samples shipped in the same cooler are evaluated to determine the extent of the contamination and the corrective action to be taken.

No trip blanks were associated with this project.

\section{Rinsates}

Rinsates are used to determine if sampling equipment that has been cleaned in the field is contaminated. Prior to sampling, DI water is poured over or pumped through portions of the sampling equipment that come in contact with the sample. If the rinsate is contaminated, the field cleaning procedure must be evaluated to determine the cause of the contamination. Results for all samples collected with equipment cleaned in the field must be evaluated to determine if the contamination is isolated or generalized.

No rinsates were associated with this project.

\subsubsection{Comparability}

The comparability of the data from the laboratories is based on the results of the split samples. For at least $10 \%$ of the sample locations, a split sample is collected and sent to the designated QC laboratory. The following table lists the RPDs, sample IDs, results that are greater than the quantitation limit for each analyte, and reporting units.

Data Summary Report for the Annual Fourmile Branch and

F- and H-Area Seeplines, Appendix IX Metals and Radionuclides, 1998

(WSRC-TR-98-00260) 
Table 3.32 Split Sample Results for GE and Recra

\begin{tabular}{|c|c|c|c|c|c|c|}
\hline \multirow[b]{2}{*}{ Analyte } & \multirow[b]{2}{*}{ RPD } & \multicolumn{2}{|c|}{ GE } & \multicolumn{2}{|c|}{ Recra } & \multirow[b]{2}{*}{ Unit } \\
\hline & & $\begin{array}{l}\text { Sample } \\
\text { ID }\end{array}$ & Result & $\begin{array}{l}\text { Sample } \\
\text { ID }\end{array}$ & Result & \\
\hline \multicolumn{7}{|l|}{ Specified Analyses } \\
\hline Chloride & 23.5 & 114012 & 2030 & 114013 & 2570 & $\mathrm{ug} / \mathrm{L}$ \\
\hline Chloride & 14.8 & 114021 & 1810 & 114022 & 2100 & $\mathrm{ug} / \mathrm{L}$ \\
\hline Hardness as $\mathrm{CACO} 3$ & 93.3 & 114012 & 4000 & 114013 & 11000 & $\mathrm{ug} / \mathrm{L}$ \\
\hline Hardness as CACO3 & 100 & 114021 & 4000 & 114022 & 12000 & $\mathrm{ug} / \mathrm{L}$ \\
\hline Nitrate as nitrogen & 77.8 & 114012 & 325 & 114013 & 143 & $\mathrm{ug} / \mathrm{L}$ \\
\hline Nitrate as nitrogen & 33.9 & 114021 & 1250 & 114022 & 1760 & $\mathrm{ug} / \mathrm{L}$ \\
\hline Nitrate-nitrite as nitrogen & 179 & 114012 & 560 & 114013 & 31 & $\mathrm{ug} / \mathrm{L}$ \\
\hline Nitrate-nitrite as nitrogen & 2.02 & 114021 & 1470 & 114022 & 1500 & $\mathrm{ug} / \mathrm{L}$ \\
\hline \multicolumn{7}{|l|}{ Metals (total recoverable) } \\
\hline Aluminum & 46 & 114012 & 13100 & 114013 & 8200 & $\mathrm{ug} / \mathrm{L}$ \\
\hline Aluminum & 24.9 & 114021 & 611 & 114022 & 785 & $\mathrm{ug} / \mathrm{L}$ \\
\hline Barium & 86.5 & 114012 & 52 & 114013 & 20.6 & $\mathrm{ug} / \mathrm{L}$ \\
\hline Barium & 14.4 & 114021 & 90 & 114022 & 104 & $\mathrm{ug} / \mathrm{L}$ \\
\hline Beryllium & 184 & 114021 & 5 & 114022 & 0.21 & $\mathrm{ug} / \mathrm{L}$ \\
\hline Cadmium & 165 & 114021 & 0.678 & 114022 & 7.1 & $\mathrm{ug} / \mathrm{L}$ \\
\hline Calcium & 31.5 & 114012 & 697 & 114013 & 958 & $\mathrm{ug} / \mathrm{L}$ \\
\hline Calcium & 20.8 & 114021 & 669 & 114022 & 824 & $\mathrm{ug} / \mathrm{L}$ \\
\hline Chromium & 40.3 & 114012 & 8.58 & 114013 & 5.7 & $\mathrm{ug} / \mathrm{L}$ \\
\hline Chromium & 137 & 114021 & 5 & 114022 & 0.93 & $\mathrm{ug} / \mathrm{L}$ \\
\hline Cobalt & 198 & 114012 & 0.741 & 114013 & 144 & $\mathrm{ug} / \mathrm{L}$ \\
\hline Cobalt & 198 & 114021 & 0.937 & 114022 & 156 & $\mathrm{ug} / \mathrm{L}$ \\
\hline Copper & 110 & 114012 & 5 & 114013 & 17.3 & $\mathrm{ug} / \mathrm{L}$ \\
\hline Copper & 100 & 114021 & 5 & 114022 & 15 & $\mathrm{ug} / \mathrm{L}$ \\
\hline Iron & 42.1 & 114012 & 6990 & 114013 & 4560 & $\mathrm{ug} / \mathrm{L}$ \\
\hline Iron & 96.7 & 114021 & 217 & 114022 & 623 & $\mathrm{ug} / \mathrm{L}$ \\
\hline Lead & 24.9 & 114012 & 6.81 & 114013 & 5.3 & $\mathrm{ug} / \mathrm{L}$ \\
\hline Lead & 179 & 114021 & 5 & 114022 & 89.5 & $\mathrm{ug} / \mathrm{L}$ \\
\hline Magnesium & 24.5 & 114012 & 445 & 114013 & 348 & $\mathrm{ug} / \mathrm{L}$ \\
\hline Magnesium & 19.2 & 114021 & 348 & 114022 & 422 & ug $/ \mathrm{L}$ \\
\hline Manganese & 52.4 & 114012 & 195 & 114013 & 114 & $\mathrm{ug} / \mathrm{L}$ \\
\hline Manganese & 23.9 & 114021 & 357 & 114022 & 454 & $\mathrm{ug} / \mathrm{L}$ \\
\hline Nickel & 184 & 114012 & 3.54 & 114013 & 85.6 & $\mathrm{ug} / \mathrm{L}$ \\
\hline Nickel & 180 & 114021 & 5 & 114022 & 92.6 & $\mathrm{ug} / \mathrm{L}$ \\
\hline Potassium & 15.9 & 114012 & 347 & 114013 & 296 & $\mathrm{ug} / \mathrm{L}$ \\
\hline Potassium & 9.67 & 114021 & 128 & 114022 & 141 & $\mathrm{ug} / \mathrm{L}$ \\
\hline Sodium & 39.6 & 114012 & 25400 & 114013 & 17000 & $\mathrm{ug} / \mathrm{L}$ \\
\hline
\end{tabular}

Data Summary Report for the Annual Fourmile Branch and F- and H-Area Seeplines, Appendix IX Metals and Radionuclides, 1998 (WSRC-TR-98-00260) 
Table 3.32 Split Sample Results for GE and Recra (cont.)

\begin{tabular}{|c|c|c|c|c|c|c|}
\hline \multirow[b]{2}{*}{ Analyte } & \multirow[b]{2}{*}{$\mathbf{R P D}$} & \multicolumn{2}{|c|}{$\mathbf{G E}$} & \multicolumn{2}{|c|}{ Recra } & \multirow[b]{2}{*}{ Unit } \\
\hline & & $\begin{array}{l}\text { Sample } \\
\text { ID }\end{array}$ & Result & $\begin{array}{l}\text { Sample } \\
\text { ID }\end{array}$ & Result & \\
\hline Sodium & 9.45 & 114021 & 2880 & 114022 & 2620 & $\mathrm{ug} / \mathrm{L}$ \\
\hline Vanadium & 52.1 & 114012 & 18.4 & 114013 & 10.8 & $\mathrm{ug} / \mathrm{L}$ \\
\hline Zinc & 56.5 & 114012 & 15.9 & 114013 & 8.9 & $\mathrm{ug} / \mathrm{L}$ \\
\hline Zinc & 10.3 & 114021 & 32.3 & 114022 & 35.8 & ug/L \\
\hline \multicolumn{7}{|l|}{ Radionuclides } \\
\hline Gross alpha & 46.2 & 114012 & 12.7 & 114013 & 7.93 & $\mathrm{pCi} / \mathrm{L}$ \\
\hline Gross alpha & 76.2 & 114021 & 5.11 & 114022 & 11.4 & $\mathrm{pCi} / \mathrm{L}$ \\
\hline Lead-212 & 134 & 114012 & 8.7 & 114013 & 1.72 & $\mathrm{pCi} / \mathrm{L}$ \\
\hline Nonvolatile beta & 3.81 & 114012 & 36.1 & 114013 & 34.75 & $\mathrm{pCi} / \mathrm{L}$ \\
\hline Nonvolatile beta & 8.57 & 114021 & 73 & 114022 & 79.54 & $\mathrm{pCi} / \mathrm{L}$ \\
\hline Potassium- 40 & 168 & 114012 & 82.9 & 114013 & 7.22 & $\mathrm{pCi} / \mathrm{L}$ \\
\hline Radium-228 & 198 & 114021 & 0.105 & 114022 & 25.99 & $\mathrm{pCi} / \mathrm{L}$ \\
\hline Strontium-90 & & 114021 & & 114022 & 19.2 & $\mathrm{pCi} / \mathrm{L}$ \\
\hline Tritium & 51 & 114012 & 227 & 114013 & 382.46 & $\mathrm{pCi} / \mathrm{mL}$ \\
\hline Tritium & 16.1 & 114021 & 88.2 & 114022 & 103.69 & $\mathrm{pCi} / \mathrm{mL}$ \\
\hline
\end{tabular}


This page was left blank intentionally. 


\subsection{References}

DOE (U.S. Department of Energy), 1992. Environmental Measurements Laboratory Procedures Manual, HASL-300, 27th edition. Environmental Measurements Laboratory, New York, NY.

EPA (U.S. Environmental Protection Agency), 1983. Methods for Chemical Analysis of Water and Wastes, EPA-600/4-79-020. Environmental Monitoring and Support Laboratory, Cincinnati, $\mathrm{OH}$.

EPA (U.S. Environmental Protection Agency), 1986. Test Methods for Evaluating Solid Waste (SW-846), Volume I, including updates. Office of Solid Waste, Washington, DC.

EPA (U.S. Environmental Protection Agency), 1988a. Laboratory Data Validation Functional Guidelines for Evaluating Inorganics Analyses. Hazardous Site Evaluation Division, Washington, DC.

EPA (U.S. Environmental Protection Agency), 1988b. Laboratory Data Validation Functional Guidelines for Evaluating Organics Analyses. Hazardous Site Evaluation Division, Washington, DC.

EPA (U.S. Environmental Protection Agency), 1990. Guidance for Data Usability in Risk Assessment, EPA/540/G-90/008. Office of Emergency and Remedial Response, Washington, DC.

EPA (U.S. Environmental Protection Agency), 1991a. U.S. EPA Contract Laboratory Program, Statement of Work for Organics Analysis, Multi-Media, MultiConcentration, OLM01.0. Washington, DC.

EPA (U.S. Environmental Protection Agency), 1991b. U.S. EPA Contract Laboratory Program, Statement of Work for Inorganics Analysis, Multi-Media, MultiConcentration, ILM03.0. Washington, DC.

EPA (U.S. Environmental Protection Agency), 1991c. Test Method: The Determination of Inorganic Anions in Water by Ion Chromatography-Method 300.0. Environmental Monitoring and Support Laboratory, Cincinnati, $\mathrm{OH}$.

EPA (U.S. Environmental Protection Agency), 1993. Data Quality Objectives Process for Superfund, EPA 540/R-93/071. Washington, DC.

EPA (U.S. Environmental Protection Agency), 1994a. Guidelines Establishing Test Procedures for the Analysis of Pollutants, Code of Federal Regulations, Title 40, Part 136. Washington, DC.

EPA (U.S. Environmental Protection Agency), 1994b. Identification and Listing of Hazardous Waste, Code of Federal Regulations, Title 40, Part 261. Washington, DC.

WHC (Westinghouse Hanford Company), not dated. Data Validation Procedures for Radiochemical Analyses, WHC-SP-EN-SPP-001, rev. 1. Richland, WA.

Data Summary Report for the Annual Fourmile Branch and

F- and H-Area Seeplines, Appendix IX Metals and Radionuclides, 1998

(WSRC-TR-98-00260) 
This page was left blank intentionally.

Data Summary Report for the Annual Fourmile Branch and

F- and H-Area Seeplines, Appendix IX Metals and Radionuclides, 1998

(WSRC-TR-98-00260) 


\section{Appendix A: Analytical Methods and Method Detection Limits}

In the following tables of analytical methods and detection limits, the MDL column reports the matrix-specific method detection limit (MDL). The MDL takes into account the reagents, sample matrix, and preparation steps of a specific analytical method, and is defined as the minimum concentration that can be measured and reported with $99 \%$ confidence that the analyte concentration is greater than zero.

\section{Table A.1 Water Analytical Methods and Detection Limits for GE}

\begin{tabular}{|c|c|c|c|}
\hline Analyte & Method & MDL & Units \\
\hline \multicolumn{4}{|l|}{ Specified Analyses } \\
\hline Chloride & EPA300.0 & 7 & $\mu \mathrm{g} / \mathrm{L}$ \\
\hline Cyanide & EPA335.3 & 3.34 & $\mu \mathrm{g} / \mathrm{L}$ \\
\hline Hardness as CACO 3 & EPA130.2 & 1000 & $\mu \mathrm{g} / \mathrm{L}$ \\
\hline Nitrate as nitrogen & EPA300.0 & 6 & $\mu \mathrm{g} / \mathrm{L}$ \\
\hline Nitrate-nitrite as nitrogen & EPA353.1 & 7 & $\mu \mathrm{g} / \mathrm{L}$ \\
\hline \multicolumn{4}{|l|}{ Metals (total recoverable) } \\
\hline Aluminum & EPA6010A & 37.6 & $\mu \mathrm{g} / \mathrm{L}$ \\
\hline Antimony & EPA6010A & 1.64 & $\mu \mathrm{g} / \mathrm{L}$ \\
\hline Arsenic & EPA6010A & 2.98 & $\mu \mathrm{g} / \mathrm{L}$ \\
\hline Barium & EPA6010A & 0.332 & $\mu \mathrm{g} / \mathrm{L}$ \\
\hline Beryllium & EPA6010A & 0.223 & $\mu \mathrm{g} / \mathrm{L}$ \\
\hline Cadmium & EPA6010A & 0.208 & $\mu \mathrm{g} / \mathrm{L}$ \\
\hline Calcium & EPA6010A & 15.4 & $\mu \mathrm{g} / \mathrm{L}$ \\
\hline Chromium & EPA6010A & 0.729 & $\mu \mathrm{g} / \mathrm{L}$ \\
\hline Cobalt & EPA6010A & 0.671 & $\mu \mathrm{g} / \mathrm{L}$ \\
\hline Copper & EPA6010A & 1.32 & $\mu \mathrm{g} / \mathrm{L}$ \\
\hline Iron & EPA6010A & 8.63 & $\mu \mathrm{g} / \mathrm{L}$ \\
\hline Lead & EPA6010A & 0.678 & $\mu \mathrm{g} / \mathrm{L}$ \\
\hline Magnesium & EPA6010A & 3.33 & $\mu \mathrm{g} / \mathrm{L}$ \\
\hline Manganese & EPA6010A & 0.903 & $\mu \mathrm{g} / \mathrm{L}$ \\
\hline Mercury & EPA7470 & 0.104 & $\mu \mathrm{g} / \mathrm{L}$ \\
\hline Nickel & EPA6010A & 2.27 & $\mu \mathrm{g} / \mathrm{L}$ \\
\hline Potassium & EPA6010A & 5.87 & $\mu \mathrm{g} / \mathrm{L}$ \\
\hline Selenium & EPA6010A & 1.4 & $\mu \mathrm{g} / \mathrm{L}$ \\
\hline Silver & EPA6010A & 0.62 & $\mu \mathrm{g} / \mathrm{L}$ \\
\hline Sodium & EPA6010A & 29.1 & $\mu \mathrm{g} / \mathrm{L}$ \\
\hline Thallium & EPA6010A & 2.63 & $\mu \mathrm{g} / \mathrm{L}$ \\
\hline Tin & EPA6010A & 2.94 & $\mu \mathrm{g} / \mathrm{L}$ \\
\hline
\end{tabular}

Data Summary Report for the Annual Fourmile Branch and 
Table A.1 Water Analytical Methods and Detection Limits for GE (cont.)

\begin{tabular}{|l|l|l|l|}
\hline Analyte & Method & MDL & Units \\
\hline Vanadium & EPA6010A & 0.427 & $\mu \mathrm{g} / \mathrm{L}$ \\
\hline Zinc & EPA6010A & 0.966 & $\mu \mathrm{g} / \mathrm{L}$ \\
\hline
\end{tabular}

Table A.2 Water Analytical Methods and Detection Limits for Recra

\begin{tabular}{|c|c|c|c|}
\hline Analyte & Method & MDL & Units \\
\hline \multicolumn{4}{|l|}{ Specified Analyses } \\
\hline Chloride & EPA9056 & 21 & $\mu \mathrm{g} / \mathrm{L}$ \\
\hline Cyanide & EPA9010A & 1.52 & $\mu \mathrm{g} / \mathrm{L}$ \\
\hline Hardness as CACO 3 & EPA130.2 & 960 & $\mu \mathrm{g} / \mathrm{L}$ \\
\hline Nitrate as nitrogen & EPA353.2 & 2 & $\mu \mathrm{g} / \mathrm{L}$ \\
\hline Nitrate-nitrite as nitrogen & EPA353.2 & 2 & $\mu \mathrm{g} / \mathrm{L}$ \\
\hline \multicolumn{4}{|l|}{ Metals (total recoverable) } \\
\hline Aluminum & EPA6010 & 14.6 & $\mu \mathrm{g} / \mathrm{L}$ \\
\hline Antimony & EPA6010 & 2.7 & $\mu \mathrm{g} / \mathrm{L}$ \\
\hline Arsenic & EPA6010 & 4 & $\mu g / \mathrm{L}$ \\
\hline Barium & EPA6010 & 0.18 & $\mu \mathrm{g} / \mathrm{L}$ \\
\hline Beryllium & EPA6010 & 0.16 & $\mu \mathrm{g} / \mathrm{L}$ \\
\hline Cadmium & EPA6010 & 0.47 & $\mu \mathrm{g} / \mathrm{L}$ \\
\hline Calcium & EPA6010 & 47.1 & $\mu \mathrm{g} / \mathrm{L}$ \\
\hline Chromium & EPA6010 & 0.7 & $\mu \mathrm{g} / \mathrm{L}$ \\
\hline Cobalt & EPA6010 & 0.45 & $\mu \mathrm{g} / \mathrm{L}$ \\
\hline Copper & EPA6010 & 1.5 & $\mu \mathrm{g} / \mathrm{L}$ \\
\hline Iron & EPA6010 & 7.4 & $\mu \mathrm{g} / \mathrm{L}$ \\
\hline Lead & EPA6010 & 4.7 & $\mu \mathrm{g} / \mathrm{L}$ \\
\hline Magnesium & EPA6010 & 7.4 & $\mu \mathrm{g} / \mathrm{L}$ \\
\hline Manganese & EPA6010 & 0.78 & $\mu \mathrm{g} / \mathrm{L}$ \\
\hline Mercury & EPA7470 & 0.045 & $\mu \mathrm{g} / \mathrm{L}$ \\
\hline Nickel & EPA6010 & 2.6 & $\mu \mathrm{g} / \mathrm{L}$ \\
\hline Potassium & EPA6010 & 18.7 & $\mu \mathrm{g} / \mathrm{L}$ \\
\hline Selenium & EPA6010 & 6.6 & $\mu \mathrm{g} / \mathrm{L}$ \\
\hline Silver & EPA6010 & 0.5 & $\mu \mathrm{g} / \mathrm{L}$ \\
\hline Sodium & EPA6010 & 28.5 & $\mu \mathrm{g} / \mathrm{L}$ \\
\hline Thallium & EPA6010 & 5.5 & $\mu \mathrm{g} / \mathrm{L}$ \\
\hline Tin & EPA6010 & 7 & $\mu \mathrm{g} / \mathrm{L}$ \\
\hline Vanadium & EPA6010 & 0.69 & $\mu \mathrm{g} / \mathrm{L}$ \\
\hline Zinc & EPA6010 & 5.3 & $\mu \mathrm{g} / \mathrm{L}$ \\
\hline
\end{tabular}

Data Summary Report for the Annual Fourmile Branch and

F- and H-Area Seeplines, Appendix IX Metals and Radionuclides, 1998

(WSRC-TR-98-00260) 
In the following tables of analytical methods and minimum detectable activities, the MDA column reports the mean matrix-specific minimum detectable activity. The MDA takes into account the reagents, sample matrix, and preparation steps of a specific analytical method, and is defined as the smallest quantity of a radionuclide that can be detected in a sample with a $95 \%$ confidence level.

Table A.3 Water Analytical Methods and Minimum Detectable Activities for EP

\begin{tabular}{|c|c|c|c|}
\hline Analyte & Method & MDA & Units \\
\hline \multicolumn{4}{|l|}{ Radionuclides } \\
\hline Actinium-228 & EPIA-013 & 18.9 & $\mathrm{pCi} / \mathrm{L}$ \\
\hline Americium-241 & EPIA-011 & 0.132 & $\mathrm{pCi} / \mathrm{L}$ \\
\hline Antimony-124 & EPIA-013 & 4.99 & $\mathrm{pCi} / \mathrm{L}$ \\
\hline Antimony- 125 & EPIA-013 & 11.1 & $\mathrm{pCi} / \mathrm{L}$ \\
\hline Barium-133 & EPIA-013 & 5.13 & $\mathrm{pCi} / \mathrm{L}$ \\
\hline Cerium-144 & EPIA-013 & 25.5 & $\mathrm{pCi} / \mathrm{L}$ \\
\hline Cesium-134 & EPIA.013 & 4.12 & $\mathrm{pCi} / \mathrm{L}$ \\
\hline Cesium-137 & EPIA.013 & 4.44 & $\mathrm{pCi} / \mathrm{L}$ \\
\hline Cobalt -57 & EPIA-013 & 3.23 & $\mathrm{pCi} / \mathrm{L}$ \\
\hline Cobalt-58 & EPIA.013 & 4.57 & $\mathrm{pCi} / \mathrm{L}$ \\
\hline Cobalt -60 & EPIA-013 & 4.76 & $\mathrm{pCi} / \mathrm{L}$ \\
\hline Curium-242 & EPIA-011 & 0.152 & $\mathrm{pCi} / \mathrm{L}$ \\
\hline Curium-243/244 & EPIA-011 & 0.145 & $\mathrm{pCi} / \mathrm{L}$ \\
\hline Curium-245/246 & EPIA.011 & 0.0613 & $\mathrm{pCi} / \mathrm{L}$ \\
\hline Europium -152 & EPIA-013 & 11.5 & $\mathrm{pCi} / \mathrm{L}$ \\
\hline Europium-154 & EPIA.013 & 12.7 & $\mathrm{pCi} / \mathrm{L}$ \\
\hline Europium 155 & EPIA-013 & 13.8 & $\mathrm{pCi} / \mathrm{L}$ \\
\hline Gross alpha & EPIA-001 & 1.1 & $\mathrm{pCi} / \mathrm{L}$ \\
\hline Iodine-129 & EPIA-006 & 1.04 & $\mathrm{pCi} / \mathrm{L}$ \\
\hline Lead-212 & EPIA-013 & 7.89 & $\mathrm{pCi} / \mathrm{L}$ \\
\hline Manganese- 54 & EPIA-013 & 4.32 & $\mathrm{pCi} / \mathrm{L}$ \\
\hline Neptunium-237 & EPIA-032 & 0.106 & $\mathrm{pCi} / \mathrm{L}$ \\
\hline Neptunium-239 & EPIA.013 & 23.9 & $\mathrm{pCi} / \mathrm{L}$ \\
\hline Nickel-6:3 & EPIA-022 & 242 & $\mathrm{pCi} / \mathrm{L}$ \\
\hline Nonvolatile beta & EPIA-001 & 1.76 & $\mathrm{pCi} / \mathrm{L}$ \\
\hline Potassium $\cdot 40$ & EPIA-013 & 51.9 & $\mathrm{pCi} / \mathrm{L}$ \\
\hline Promethium-144 & EPIA-013 & 4.27 & $\mathrm{pCi} / \mathrm{L}$ \\
\hline Promethium-146 & EPIA-013 & 5.29 & $\mathrm{pCi} / \mathrm{L}$ \\
\hline Radium-226 & EPIA-008 & 0.486 & $\mathrm{pCi} / \mathrm{L}$ \\
\hline Radium-228 & EPIA.009 & 0.84 & $\mathrm{pCi} / \mathrm{L}$ \\
\hline Ruthenium.106 & EPIA.013 & 38.8 & $\mathrm{pCi} / \mathrm{L}$ \\
\hline Sodium-22 & EPIA-013 & 4.52 & $\mathrm{pCi} / \mathrm{L}$ \\
\hline Tin-113 & EPIA-013 & 5.42 & $\mathrm{pCi} / \mathrm{L}$ \\
\hline
\end{tabular}

Data Summary Report for the Annual Fourmile Branch and

F- and H-Area Seeplines, Appendix IX Metals and Radionuclides, 1998

(WSRC-TR-98-00260) 
Table A.3 Water Analytical Methods and Minimum Detectable Activities for EP (cont.)

\begin{tabular}{|l|l|l|l|}
\hline Analyte & Method & MDA & Units \\
\hline Tritium & EPA906.0 & 0.888 & $\mathrm{pCi} / \mathrm{mL}$ \\
\hline Uranium-233/234 & EPIA-011 & 0.164 & $\mathrm{pCi} / \mathrm{L}$ \\
\hline Uranium-235 & EPIA-011 & 0.179 & $\mathrm{pCi} / \mathrm{L}$ \\
\hline Uranium-238 & EPIA-011 & 0.201 & $\mathrm{pCi} / \mathrm{L}$ \\
\hline Yttrium-88 & EPIA-013 & 5.51 & $\mathrm{pCi} / \mathrm{L}$ \\
\hline Zinc-65 & EPIA-013 & 9.24 & $\mathrm{pCi} / \mathrm{L}$ \\
\hline Zirconium-95 & EPIA-013 & 8.34 & $\mathrm{pCi} / \mathrm{L}$ \\
\hline
\end{tabular}

Table A.4 Water Analytical Methods and Minimum Detectable Activities for TNU

\begin{tabular}{|c|c|c|c|}
\hline Analyte & Method & MDA & Units \\
\hline \multicolumn{4}{|l|}{ Radionuclides } \\
\hline Actinium-228 & EPA901.1MOD & 14.2 & $\mathrm{pCi} / \mathrm{L}$ \\
\hline Antimony 124 & EPA901.1MOD & 4.85 & $\mathrm{pCi} / \mathrm{L}$ \\
\hline Antimony-125 & EPA901.1MOD & 8.33 & $\mathrm{pCi} / \mathrm{L}$ \\
\hline Barium-133 & EPA901.1MOD & 4.02 & $\mathrm{pCi} / \mathrm{L}$ \\
\hline Cerium $\cdot 144$ & EPA901.1MOD & 17.2 & $\mathrm{pCi} / \mathrm{L}$ \\
\hline Cesium-134 & EPA901.1MOD & 3.58 & $\mathrm{pCi} / \mathrm{L}$ \\
\hline Cesium-137 & EPA901.1MOD & 3.92 & $\mathrm{pCi} / \mathrm{L}$ \\
\hline Cobalt-57 & EPA901.1MOD & 2.27 & $\mathrm{pCi} / \mathrm{L}$ \\
\hline $\begin{array}{l}\text { Cobalt }-58 \\
\end{array}$ & EPA901.1MOD & 4.48 & $\mathrm{pCi} / \mathrm{L}$ \\
\hline Cobalt -60 & EPA901.1MOD & 3.67 & $\mathrm{pCi} / \mathrm{L}$ \\
\hline Europium-152 & EPA901.1MOD & 27.6 & $\mathrm{pCi} / \mathrm{L}$ \\
\hline Europium-154 & EPA901.1MOD & 12.1 & $\mathrm{pCi} / \mathrm{L}$ \\
\hline Europium -155 & EPA901.1MOD & 6.99 & $\mathrm{pCi} / \mathrm{L}$ \\
\hline Gross alpha & EPA900.0MOD & 1.51 & $\mathrm{pCi} / \mathrm{L}$ \\
\hline Iodine-129 & EPA902.0MOD & 10.5 & $\mathrm{pCi} / \mathrm{L}$ \\
\hline Lead-212 & EPA901.1MOD & 4.95 & $\mathrm{pCi} / \mathrm{L}$ \\
\hline Manganese-54 & EPA901.1MOD & 3.85 & $\mathrm{pCi} / \mathrm{L}$ \\
\hline Nickel-63 & 3500NIEMOD & 12.6 & $\mathrm{pCi} / \mathrm{L}$ \\
\hline Nonvolatile beta & EPA900.0MOD & 2.14 & $\mathrm{pCi} / \mathrm{L}$ \\
\hline Potassium-40 & EPA901.1MOD & 37.3 & $\mathrm{pCi} / \mathrm{L}$ \\
\hline Promethium-144 & EPA901.1MOD & 3.88 & $\mathrm{pCi} / \mathrm{L}$ \\
\hline Promethium-146 & EPA901.1MOD & 6.17 & $\mathrm{pCi} / \mathrm{L}$ \\
\hline Radium-228 & EPA904.0MOD & 6.76 & $\mathrm{pCi} / \mathrm{L}$ \\
\hline Ruthenium-106 & EPA901.1MOD & 33.5 & $\mathrm{pCi} / \mathrm{L}$ \\
\hline
\end{tabular}

Data Summary Report for the Annual Fourmile Branch and

F- and H-Area Seeplines, Appendix IX Metals and Radionuclides, 1998

(WSRC-TR-98-00260) 
Table A.4 Water Analytical Methods and Minimum Detectable Activities for TNU (cont.)

\begin{tabular}{|l|l|l|l|}
\hline Analyte & Method & MDA & Units \\
\hline Sodium-22 & EPA901.1MOD & 4.36 & pCi/L \\
\hline Strontium-90 & EMLSR02MOD & 1.84 & $\mathrm{pCi} / \mathrm{L}$ \\
\hline Tin-113 & EPA901.1MOD & 4.65 & $\mathrm{pCi} / \mathrm{L}$ \\
\hline Tritium & EPA906.0MOD & 0.623 & $\mathrm{pCi} / \mathrm{mL}$ \\
\hline Yttrium-88 & EPA901.1MOD & 4.34 & $\mathrm{pCi} / \mathrm{L}$ \\
\hline Zinc-65 & EPA901.1MOD & 7.59 & $\mathrm{pCi} / \mathrm{L}$ \\
\hline Zirconium-95 & EPA901.1MOD & 8.72 & $\mathrm{pCi} / \mathrm{L}$ \\
\hline
\end{tabular}


This page was left blank intentionally. 


\section{Appendix B: Laboratory Performance Evaluation Results}

This appendix contains recent performance evaluation results for the laboratories that report data for soils and groundwater samples. Not all laboratories report data for each project.

\section{B.1 EPA Performance Evaluation Study Results}

EPA conducts the water pollution (WP) and water supply (WS) performance evaluation studies biannually to certify laboratories for specific analyses. EPA's Environmental Monitoring Systems Laboratory (EMSL) of Cincinnati, OH, distributes water samples spiked with known concentrations of constituents found in polluted waters and potable water and submits them to laboratories seeking certification to analyze wastewater and potable water. EMSL evaluates the results, using limits statistically based on the performance of approximately 100 top-rated laboratories that analyze each constituent by the same procedure as the laboratory being evaluated.

All laboratories reported results for WP036, and EMAX, QST, and Recra reported results for WP037.

For study WP036, the results from EMAX were outside the acceptance limits for chloride, potassium, and sodium. The results for dibromochloro-methane and nonfilterable residue were acceptable but near the acceptance limits; EMAX was instructed to check for error. The results from GE were outside the acceptance limits for fluoride, magnesium, potassium, and total phosphorus. In addition, the results for benzene and methylene chloride were acceptable but near the acceptance limits; GE was instructed to check for error. The results from QST were outside the acceptance limits for chloroform and methylene chloride. In addition, the results for 5-day biochemical oxygen demand, bromodichloromethane, 1,3-dichlorobenzene, and tetrachloroethylene were acceptable but near the acceptance limits; QST was instructed to check for error. The results from Recra for all analytes were within acceptance limits.

For study WP037, the results for EMAX were outside the acceptance limits for fluoride, total phosphorus, and total phenolics. The results for QST were outside the acceptance limits for beryllium and total phenolics. The result for carbonaceous biochemical oxygen demand was acceptable but near the acceptance limits; QST was instructed to check for error. The results for Recra were outside the acceptance limits for calcium, total organic carbon, and nonfilterable residue. The results for magnesium and sodium were acceptable but near the acceptance limits; Recra was instructed to check for error.

EMAX and QST reported results for WS037, and EMAX, GE, and QST reported results for WS038.

For WS037, the results for EMAX were outside the acceptance limits for dieldrin, endrin, nitrite, orthophosphate, propachlor, total organic carbon, toxaphene, and trifluralin. The results for QST were outside the acceptance limits for 2,4-D, hardness, nitrate, pentachlorophenol, total organic carbon, and 2,4,5-TP (Silvex). 
For WS038, the results for EMAX were outside the acceptance limits for 2,4-D, propachlor, tetrachloroethylene, and total organic carbon. The results for GE were outside the acceptance limits for dicamba and zinc. The results for QST were outside the acceptance limits for 2,4-D, cis-1,2-dichloroethylene, and orthophosphate.

\section{B.2 EMS Quality Control Standards Results}

During second quarter 1997, EPD/EMS conducted quality assessments of the laboratories. Each laboratory received a set of certified environmental quality control standards from Environmental Resource Associates (ERA) of Arvada, CO (lot numbers 573, 3218, 3418, 8915, and 9973). Each laboratory's results were compared with the ERA-certified values and performance acceptance limits (PALs). The PALs are listed as guidelines for acceptable analytical results given the limitations of the EPA methods used to determine these parameters. The PALs closely approximate the $95 \%$ confidence interval.

Of the 100 analyses reported by GE, 96 (or $96 \%$ ), were within the PALs. Of 99 analyses reported by Recra, 94 (or $95 \%$ ), were within the PALs. Of the 100 analyses reported by QST, 97 (or $97 \%$ ) were within the PALs. Of the 98 analyses reported by EMAX, 91 (or 93\%) were within the PALs.

\section{B.3 Mixed Analyte Performance Evaluation Program}

The Department of Energy mixed analyte performance evaluation program provides proficiency samples containing metals, pesticides, and radionuclides. The results from the June 1996 MAPEP-96-S3 study were reported in December 1996. GE and Recra reported only chemical analyses, and EP and TNU reported only radionuclide analyes.

For GE, copper was not acceptable and nickel was reported at $23.4 \mathrm{mg} / \mathrm{kg}$ although it was not included in the original sample. Five of the eight pesticides had a negative bias and were not acceptable; 4,4'.DDE and methoxychlor were not reported. For Recra, all the metals were within the acceptance limits. Four of the eight pesticides were not acceptable, three were acceptable, and methoxychlor was not reported.

For EP, all eight radionuclides were acceptable, but plutonium-238 was close to the upper acceptance limit and given a warning flag. For TNU, seven of eight radionuclides were within the acceptance limits; however the result for strontium-90 was not acceptable. The results for $\mathrm{EP}$ and $\mathrm{TNU}$ are reported in table B.1.

The results for MAPEP-96-W4 were reported in April 1997. For QST, the results for 4methylphenol and phenol were outside the acceptance limits. 
Table B.1 Mixed Analyte Performance Evaluation Program Results for MAPEP96-S3 for EP and TNU

\begin{tabular}{|l|l|l|l|l|}
\hline & EP Result & TNU Result & $\begin{array}{l}\text { Reference } \\
\text { Value }\end{array}$ & $\begin{array}{l}\text { Acceptance } \\
\text { Limits }\end{array}$ \\
\hline \multicolumn{5}{|l|}{} \\
\hline Radionuclides (Bq/kg) & 29.0 & 28.7 & 28.7 & $20.09-37.31$ \\
\hline Americium-241 & 1770 & 1359 & 1531 & $1071.7-1990.3$ \\
\hline Cesium-137 & 931 & 727 & 812 & $568.4-1055.6$ \\
\hline Cobalt-60 & $20.5^{\mathrm{a}}$ & 17.3 & 15.9 & $11.13-20.67$ \\
\hline Plutonium-238 & 22.6 & 18.9 & 19.7 & $13.79-25.61$ \\
\hline Plutonium-239/240 & 540 & $\mathbf{3 4 7}$ & 536.0 & $375.2-696.8$ \\
\hline Strontium-90 & 56.6 & 59.7 & 63.9 & $44.73-83.07$ \\
\hline Uranium-233/234 & 52.9 & 59.7 & 64.0 & $44.80-83.20$ \\
\hline Uranium-238 &
\end{tabular}

\section{B.4 EPA Radiological Performance Evaluation Studies}

$\mathrm{EP}$ and $\mathrm{QR}$ participated in the EPA radiological performance evaluation studies administered by the Characterization Research Division-Las Vegas. The studies included in this order are the following:

- Tritium in water, August 9, 1996

- Blind-A, October 15, 1996

- Blind-B, October 15, 1996

- Gamma in water, November 8, 1996

- Strontium in water, January 17,1997

- Gross alpha-beta in water, January 31,1997

- Iodine in water, February 7, 1997

- Uranium-radium in water, February 14,1997

For tritium in water (8/9/96), the results were $9,613 \mathrm{pCi} / \mathrm{L}$ for $\mathrm{EP}$ and $10,707 \mathrm{pCi} / \mathrm{L}$ for $\mathrm{QR}$. The EPA reference value was $10,879 \mathrm{pCi} / \mathrm{L}$ and the acceptance limits were $8,991-12,767$ $\mathrm{pCi} / \mathrm{L}$.

For iodine in water (2/7/97), both EP and QR reported results of $88.00 \mathrm{pCi} / \mathrm{L}$. The EPA reference value was $86.0 \mathrm{pCi} / \mathrm{L}$ and the acceptance limits were $70.4-101.6 \mathrm{pCi} / \mathrm{L}$.

In the following tables, all results are reported in $\mathrm{pCi} / \mathrm{L}$.

a In cases where a warning was given, the reported values appear in bold italic.

b Reported values that were outside the acceptance limits appear in bold. 
Table B.2 Blind-A Results for EP and QR (10/15/96)

\begin{tabular}{|l|l|l|l|l|}
\hline Analyte & EP Result & QR Result & $\begin{array}{l}\text { Reference } \\
\text { Value }\end{array}$ & $\begin{array}{l}\text { Acceptance } \\
\text { Limits }\end{array}$ \\
\hline Gross alpha & 65.27 & 48.87 & 59.1 & $33.4-84.8$ \\
\hline Radium-226 & 9.40 & 9.60 & 9.9 & $7.3-12.5$ \\
\hline Radium-228 & 4.67 & 4.57 & 5.1 & $2.8-7.4$ \\
\hline Uranium (natural) & 37.33 & 40.10 & 40.9 & $33.8-48.0$ \\
\hline
\end{tabular}

Table B.3 Blind-B Results for EP and QR (10/15/96)

\begin{tabular}{|l|l|l|l|l|}
\hline Analyte & EP Result & QR Result & $\begin{array}{l}\text { Reference } \\
\text { Value }\end{array}$ & $\begin{array}{l}\text { Acceptance } \\
\text { Limits }\end{array}$ \\
\hline Cesium-134 & 18.00 & 18.00 & 20.0 & $11.3-28.7$ \\
\hline Cesium-137 & 31.33 & 30.67 & 30.0 & $21.3-38.7$ \\
\hline Cobalt-60 & 15.33 & 15.33 & 15.0 & $6.3-23.7$ \\
\hline Gross beta & $43.43^{c}$ & 119.67 & 111.8 & $82.7-140.9$ \\
\hline Strontium-89 & 11.67 & 16.67 & 10.0 & $1.3-18.7$ \\
\hline Strontium-90 & 24.67 & 21.33 & 25.0 & $16.3-33.7$ \\
\hline
\end{tabular}

Table B.4 Gamma in Water Results for EP and QR (11/8/96)

\begin{tabular}{|l|l|l|l|l|}
\hline Analyte & EP Result & QR Result & $\begin{array}{l}\text { Reference } \\
\text { Value }\end{array}$ & $\begin{array}{l}\text { Acceptance } \\
\text { Limits }\end{array}$ \\
\hline Cobalt-60 & 45.67 & 43.33 & 44.0 & $35.3-52.7$ \\
\hline Zinc-65 & 39.33 & 36.67 & 35.0 & $26.3-43.7$ \\
\hline Cesium-134 & 10.67 & 9.33 & 11.0 & $2.3-19.7$ \\
\hline Cesium-137 & 22.67 & 20.33 & 19.0 & $10.3-27.7$ \\
\hline Barium-133 & 64.67 & 61.00 & 64.0 & $53.6-74.4$ \\
\hline
\end{tabular}

Table B.5 Strontium in Water Results for EP and QR (1/17/97)

\begin{tabular}{|l|l|l|l|l|}
\hline Analyte & EP Result & QR Result & $\begin{array}{l}\text { Reference } \\
\text { Value }\end{array}$ & $\begin{array}{l}\text { Acceptance } \\
\text { Limits }\end{array}$ \\
\hline Strontium-89 & 8.67 & 11.00 & 12.0 & $3.3-20.7$ \\
\hline Strontium-90 & 26.33 & 24.33 & 25.0 & $16.3-33.7$ \\
\hline
\end{tabular}

c Reported values that were out of range appear in bold. 
Table B.6 Gross Alpha-Beta in Water Results for EP and QR (1/31/97)

\begin{tabular}{|l|l|l|l|l|}
\hline Analyte & EP Result & QR Result & $\begin{array}{l}\text { Reference } \\
\text { Value }\end{array}$ & $\begin{array}{l}\text { Acceptance } \\
\text { Limits }\end{array}$ \\
\hline Gross alpha & 4.83 & 4.60 & 5.2 & $0.0-13.9$ \\
\hline Gross beta & 14.23 & 17.40 & 14.7 & $6.0-23.4$ \\
\hline
\end{tabular}

Table B.7 Uranium-Radium in Water Results for EP and QR (2/14/97)

\begin{tabular}{|l|l|l|l|l|}
\hline & EP Result & QR Result & $\begin{array}{l}\text { Reference } \\
\text { Value }\end{array}$ & $\begin{array}{l}\text { Acceptance } \\
\text { Limits }\end{array}$ \\
\hline Radium-226 & 5.17 & 5.90 & 5.9 & $4.3-7.5$ \\
\hline Radium-228 & 7.30 & 8.33 & 8.2 & $4.6-11.8$ \\
\hline Uranium (natural) & 32.07 & 27.8 & 27.0 & $21.8-32.2$ \\
\hline
\end{tabular}


This page was left blank intentionally. 


\section{Appendix C: Formats of the Data Files}

The formats presented in this appendix have been established by WSRC-EPD/EMS. When entering data in any of the formats, the following conventions are to be used:

- Alpha and alphanumeric entries must be left justified in the records.

- Numeric entries must be right justified in the records.

- There will be no leading zeros except in dates and times.

Table C.1 describes the sample data format, SAM93, which is used for coding and transmitting sampling data records.

Table C.1 Sample Data Format SAM93

\begin{tabular}{|c|c|c|c|}
\hline Name & Columns & Type & Description \\
\hline Record format & $1-8$ & Alphanumeric & SAM93 (the format of the data record) \\
\hline $\begin{array}{l}\text { Sample } \\
\text { identification } \\
\text { number }\end{array}$ & $9-14$ & Integer & $\begin{array}{l}\text { Number of the sample printed on the page } \\
\text { of the sample logbook }\end{array}$ \\
\hline $\begin{array}{l}\text { Sample collection } \\
\text { date }\end{array}$ & $15-20$ & Numeric & $\begin{array}{l}\text { Sample collection date recorded using the } \\
\text { MMDDYY format }\end{array}$ \\
\hline $\begin{array}{l}\text { Sample collection } \\
\text { time }\end{array}$ & $21-24$ & Integer & $\begin{array}{l}\text { Sample collection time recorded as } \\
\text { military time }\end{array}$ \\
\hline Sample type & 25 & Numeric & $\begin{array}{l}\text { Sample type coded as } \\
1=\text { normal } \\
2=\text { trip blank } \\
3=\text { field blank } \\
4=\text { split } \\
5=\text { rinsate } \\
6=\text { duplicate } \\
7=\text { other }\end{array}$ \\
\hline Sample matrix & 26 & Numeric & $\begin{array}{l}\text { Sample matrix coded as } \\
1=\text { soil } \\
2=\text { rock } \\
3=\text { sludge } \\
4=\text { water } \\
5=\text { sediment } \\
6=\text { other }\end{array}$ \\
\hline Delay check & 27 & Alpha & $\begin{array}{l}\text { Enter a } Y \text { if there was an unusual delay in } \\
\text { bottling samples }\end{array}$ \\
\hline Sampler's initials & $28-30$ & Alpha & Sampler's initials \\
\hline Associated sample & $31-36$ & Integer & $\begin{array}{l}\text { Sample identification of associated sample } \\
\text { if this sample is a duplicate, split, rinsate, } \\
\text { etc. }\end{array}$ \\
\hline
\end{tabular}


Table C.1 Sample Data Format SAM93 (cont.)

\begin{tabular}{|c|c|c|c|}
\hline Name & Columns & Type & Description \\
\hline $\begin{array}{l}\text { Planned sample } \\
\text { name }\end{array}$ & $37-46$ & Alphanumeric & $\begin{array}{l}\text { Identification of the sample as it appears } \\
\text { in the site work plan }\end{array}$ \\
\hline Sample name & $47-56$ & Alphanumeric & $\begin{array}{l}\text { Identification of the actual sample } \\
\text { (includes any modification made in the } \\
\text { field) }\end{array}$ \\
\hline $\begin{array}{l}\text { Planned top of } \\
\text { interval }\end{array}$ & $57-62$ & Numeric & $\begin{array}{l}\text { Depth from the ground to the top of the } \\
\text { planned sampling interval to the nearest } \\
0.01 \mathrm{ft}\end{array}$ \\
\hline Top of interval & $63-68$ & Numeric & $\begin{array}{l}\text { Depth from the ground to the top of the } \\
\text { actual sampling interval to the nearest } \\
0.01 \mathrm{ft}\end{array}$ \\
\hline $\begin{array}{l}\text { Planned bottom of } \\
\text { interval }\end{array}$ & $69-74$ & Numeric & $\begin{array}{l}\text { Depth from the ground to the bottom of } \\
\text { the planned sampling interval to the } \\
\text { nearest } 0.01 \mathrm{ft}\end{array}$ \\
\hline Bottom of interval & $75-80$ & Numeric & $\begin{array}{l}\text { Depth from the ground to the bottom of } \\
\text { the actual sampling interval to the } \\
\text { nearest } 0.01 \mathrm{ft}\end{array}$ \\
\hline Soil moisture $^{a}$ & 81 & Numeric & $\begin{array}{l}\text { Soil moisture coded as } \\
1=\text { dry } \\
2=\text { damp } \\
3=\text { wet } \\
4=\text { sludge } \\
5=\text { liquid }\end{array}$ \\
\hline Munsell color ${ }^{\mathrm{a}}$ & $82-91$ & Alphanumeric & Munsell color \\
\hline Soil classification $^{\mathrm{a}}$ & $92-93$ & Alphanumeric & Unified Soil Classification \\
\hline Number of bottles & $94-96$ & Integer & $\begin{array}{l}\text { Number of bottle label numbers used } \\
\text { during collection }\end{array}$ \\
\hline $\begin{array}{l}\text { Insufficient } \\
\text { recovery check }\end{array}$ & 97 & Alpha & $\begin{array}{l}\text { Enter an } R \text { if insufficient material was } \\
\text { recovered to perform all analyses }\end{array}$ \\
\hline $\begin{array}{l}\text { Improper } \\
\text { procedure check }\end{array}$ & 98 & Alpha & $\begin{array}{l}\text { Enter a } P \text { if an improper sampling } \\
\text { procedure was followed }\end{array}$ \\
\hline Sampling tool ${ }^{\mathrm{b}}$ & 99 & Numeric & $\begin{array}{l}\text { Instrument type coded as } \\
1=\text { hand auger } \\
2 \text { - drill rig } \\
3 \text { - pump } \\
4 \text { - bailer } \\
5=\text { scoop } \\
6=\text { other }\end{array}$ \\
\hline
\end{tabular}

a No datum is reported for this field.

b This field is not a part of the official data format.

Data Summary Report for the Annual Fourmile Branch and 
Table C.2 is a description of the sample bottle data format, SAM93A, which is used for coding and transmitting sample bottle data records.

Table C.2 Sample Bottle Data Format SAM93A

\begin{tabular}{|l|l|l|l|}
\hline Name & Columns & Type & Description \\
\hline Record format & $1-8$ & Alphanumeric & $\begin{array}{l}\text { SAM93A (the format of the data } \\
\text { record) }\end{array}$ \\
\hline $\begin{array}{l}\text { Sample identification } \\
\text { number }\end{array}$ & $9-14$ & Integer & $\begin{array}{l}\text { Number of the sample printed on the } \\
\text { page of the sample logbook }\end{array}$ \\
\hline Bottle label number & $15-23$ & Integer & $\begin{array}{l}\text { Number of the bottle label attached to } \\
\text { the bottle }\end{array}$ \\
\hline
\end{tabular}

Table C.3 is a description of the survey station data format, STA93, which is used for coding and transmitting station data records.

Table C.3 Survey Station Data Förmat STA93

\begin{tabular}{|l|l|l|l|}
\hline Name & Columns & Type & Description \\
\hline Record format & $1-8$ & Alphanumeric & STA93 (the format of the data record) \\
\hline Station & $9-18$ & Alphanumeric & $\begin{array}{l}\text { Identification of the station (the facility } \\
\text { identification and sampling point) }\end{array}$ \\
\hline SRS north coordinate & $20-27$ & Numeric & $\begin{array}{l}\text { SRS grid north coordinate of the } \\
\text { station reported in feet }\end{array}$ \\
\hline SRS east coordinate & $29-36$ & Numeric & $\begin{array}{l}\text { SRS grid east coordinate of the station } \\
\text { reported in feet }\end{array}$ \\
\hline Ground elevation & $43-48$ & Numeric & $\begin{array}{l}\text { Ground elevation reported in feet above } \\
\text { median sea level }\end{array}$ \\
\hline
\end{tabular}


Table C.4 is a description of the chain-of-custody data format, COC93, which is used for coding and transmitting chain-of-custody data records.

Table C.4 Chain-of-Custody Data Format COC93

\begin{tabular}{|l|l|l|l|}
\hline Name & Columns & Type & Description \\
\hline Record format & $1-8$ & Alphanumeric & COC93 (the format of the data record) \\
\hline $\begin{array}{l}\text { Sample identification } \\
\text { number }\end{array}$ & $9-18$ & Integer & $\begin{array}{l}\text { Number of the sample printed on the } \\
\text { page of the sample logbook }\end{array}$ \\
\hline $\begin{array}{l}\text { Laboratory sample } \\
\text { identification }\end{array}$ & $19-33$ & Alphanumeric & $\begin{array}{l}\text { Identifier used for the sample by the } \\
\text { analytical laboratory }\end{array}$ \\
\hline Sample collection date & $34-39$ & Numeric & $\begin{array}{l}\text { Sample collection date recorded using the } \\
\text { MMDDYY format }\end{array}$ \\
\hline Shipping date & $40-45$ & Numeric & $\begin{array}{l}\text { Sample shipping date recorded using the } \\
\text { MMDDYY format }\end{array}$ \\
\hline Cooler identification & $46-53$ & Alphanumeric & $\begin{array}{l}\text { Number assigned to the cooler in which } \\
\text { the samples are shipped to the analytical } \\
\text { laboratory }\end{array}$ \\
\hline $\begin{array}{l}\text { Sample temperature } \\
\text { upon receipt }\end{array}$ & $54-57$ & Numeric & $\begin{array}{l}\text { Temperature of the samples upon receipt } \\
\text { at the analytical laboratory in }{ }^{\circ} \mathrm{C}\end{array}$ \\
\hline
\end{tabular}

Table C.5 is a description of the analytical data format, AN95, which is used for coding and transmitting analytical data records.

Table C.5 Analytical Data Format AN95

\begin{tabular}{|l|l|l|l|}
\hline Name & Columns & Type & Description \\
\hline WSRC identifier & $1-12$ & Alphanumeric & WSRC identifier for the sample \\
\hline COC number & $13-17$ & Alphanumeric & $\begin{array}{l}\text { Identifier of the sample's chain-of- } \\
\text { custody form (Required field for } \\
\text { groundwater samples; not used for soil } \\
\text { samples) }\end{array}$ \\
\hline Sample collection date & $18-23$ & Numeric & $\begin{array}{l}\text { Date the sample was collected. Enter } \\
\text { the preparation date for laboratory } \\
\text { blanks and QC samples; enter the date of } \\
\text { completion of TCLP sample generation } \\
\text { for TCLP samples }\end{array}$ \\
\hline Sample collection time & $24-27$ & Numeric & \begin{tabular}{l} 
Time of sample collection or generation \\
\hline Lab receipt date
\end{tabular} \\
\hline Extraction date & $34-39$ & Numeric & $\begin{array}{l}\text { Date the sample was received by the } \\
\text { laboratory; blank for laboratory blanks } \\
\text { and QC samples }\end{array}$ \\
\hline & Numeric & $\begin{array}{l}\text { Date the sample was extracted; blank } \\
\text { unless the holding time is dependent } \\
\text { upon the extraction time }\end{array}$ \\
\hline
\end{tabular}

a This field must have an entry for every record.

Data Summary Report for the Annual Fourmile Branch and

F- and H-Area Seeplines, Appendix IX Metals and Radionuclides, 1998

(WSRC-TR-98-00260) 
Table C.5 Analytical Data Format AN95 (cont.)

\begin{tabular}{|c|c|c|c|}
\hline Name & Columns & Type & Description \\
\hline Extraction time & $40-43$ & Numeric & $\begin{array}{l}\text { Time the sample extraction was started; } \\
\text { blank unless the holding time is } \\
\text { dependent upon the extraction time }\end{array}$ \\
\hline $\begin{array}{l}\text { Extraction/digestion } \\
\text { method }\end{array}$ & $44-56$ & Alphanumeric & $\begin{array}{l}\text { Coded identifier for the method used to } \\
\text { perform the extraction or digestion (e.g., } \\
\text { EPA\#\#.\#) }\end{array}$ \\
\hline Analysis date ${ }^{a}$ & $57-62$ & Numeric & $\begin{array}{l}\text { Date the analyte concentration was } \\
\text { determined }\end{array}$ \\
\hline Analysis time $e^{a}$ & $63-66$ & Numeric & $\begin{array}{l}\text { Time the analyte concentration was } \\
\text { determined }\end{array}$ \\
\hline Analytical methoda & $67-79$ & Alphanumeric & $\begin{array}{l}\text { Coded identifier for the method used to } \\
\text { perform the analysis (e.g., EPA\#\#.\#) }\end{array}$ \\
\hline Preparation batch & $80-87$ & Alphanumeric & $\begin{array}{l}\text { Identification of the sample preparation } \\
\text { batch }\end{array}$ \\
\hline Laboratory ${ }^{a}$ & $88-89$ & Alphanumeric & $\begin{array}{l}\text { Code assigned by EPD/EMS to identify } \\
\text { the laboratory performing the analysis }\end{array}$ \\
\hline $\begin{array}{l}\text { Laboratory sample } \\
\text { identification }^{\mathrm{a}}\end{array}$ & $90-104$ & Alphanumeric & $\begin{array}{l}\text { Identifier used for the sample by the } \\
\text { analytical laboratory. }\end{array}$ \\
\hline Laboratory replicate & $105-107$ & Alphanumeric & $\begin{array}{l}\text { Indicates that the sample is a non-blind } \\
\text { replicate analysis (see table C. } 7 \text { ) }\end{array}$ \\
\hline Analyte $^{a}$ & $108-117$ & Alphanumeric & EPD/EMS identifier for the analyte \\
\hline Quantitation limit & $118-125$ & Numeric & $\begin{array}{l}\text { GE and WA report the ssEQL for non- } \\
\text { radiochemistry analyses; all labs report } \\
\text { the MDA for radiochemistry analyses }\end{array}$ \\
\hline Result qualifier & $126-128$ & Alphanumeric & $\begin{array}{l}\text { Coded field used to qualify the analytical } \\
\text { result (see table D. 1) }\end{array}$ \\
\hline Analysis qualifier & $129-131$ & Alphanumeric & $\begin{array}{l}\text { Coded field used to qualify the analytical } \\
\text { result (see table D.2) }\end{array}$ \\
\hline Bias of analysis & 132 & Alphanumeric & $\begin{array}{l}\text { Coded field for specifying the expected } \\
\text { bias (see table D.3) }\end{array}$ \\
\hline Analytical result & $13: 3-142$ & Numeric & $\begin{array}{l}\text { Concentration of the analyte. For non- } \\
\text { detects, the ssEQL is reported. Results } \\
\text { are reported on a dry weight basis for all } \\
\text { analyses reported in per mass units }\end{array}$ \\
\hline Result unit" & $143-146$ & Alpha & $\begin{array}{l}\text { Unit in which the analytical result is } \\
\text { expressed }\end{array}$ \\
\hline Accuracy & $147-154$ & Numeric & $\begin{array}{l}\text { Statistically determined value, } 95 \% \\
\text { confidence level, representing a plus or } \\
\text { minus value for the result and reported } \\
\text { in the same units as the analytical } \\
\text { result. Required for all radiochemical } \\
\text { analyses above the detection limit, but } \\
\text { not generally reported for non- } \\
\text { radiochemical analyses. Do not report } \\
\text { more figures than are significant }\end{array}$ \\
\hline
\end{tabular}

Data Summary Report for the Annual Fourmile Branch and 
Table C.5 Analytical Data Format AN95 (cont.)

\begin{tabular}{|c|c|c|c|}
\hline Name & Columns & Type & Description \\
\hline Residual weight & $155-160$ & Numeric & $\begin{array}{l}\text { Weight of material in milligrams on the } \\
\text { planchet after evaporation; used for } \\
\text { radionuclide determinations }\end{array}$ \\
\hline Nominal concentration ${ }^{a}$ & $161-168$ & Numeric & $\begin{array}{l}\text { Concentration of analyte added to the } \\
\text { sample prior to analysis; reported in the } \\
\text { same units as the analytical result. Zero } \\
\text { must be entered if the sample was not } \\
\text { spiked }\end{array}$ \\
\hline Percent recovery & $169-174$ & Numeric & $\begin{array}{l}\text { Recovery of the spiked constituent } \\
\text { reported as a percentage }\end{array}$ \\
\hline Number of dilutions ${ }^{a}$ & 175 & Numeric & $\begin{array}{l}\text { Number of steps required to reach the } \\
\text { final dilution factor. Zero must be } \\
\text { entered if the sample was not diluted }\end{array}$ \\
\hline Dilution factor ${ }^{a}$ & $176-181$ & Numeric & $\begin{array}{l}\text { Dilution used in the analysis; a value of } \\
\text { one indicates the sample was not diluted }\end{array}$ \\
\hline Instrument & $182-189$ & Alphanumeric & $\begin{array}{l}\text { Coded identifier for the instrument used } \\
\text { to perform the analysis; each laboratory } \\
\text { develops its own codes and provides } \\
\text { them to EPD/EMS }\end{array}$ \\
\hline Instrument batch ${ }^{a}$ & $190-197$ & Alphanumeric & $\begin{array}{l}\text { Number assigned by the analytical } \\
\text { laboratory to the analysis batch (group } \\
\text { of samples analyzed together in a single } \\
\text { instrument run along with the } \\
\text { associated QC samples) }\end{array}$ \\
\hline Analyst's initials ${ }^{\mathbf{a}}$ & $198-200$ & Alpha & Initials of the analyst \\
\hline Percent solids & $201-205$ & Numeric & $\begin{array}{l}\text { Percentage of the sample that is dry } \\
\text { solids; required field if result is reported } \\
\text { in per mass units; not applicable for } \\
\text { water samples }\end{array}$ \\
\hline Bottle label number & $206-215$ & Integer & $\begin{array}{l}\text { Number on the bottle label; required } \\
\text { field if bottle label is numbered }\end{array}$ \\
\hline Sample fraction & $216-219$ & Alphanumeric & $\begin{array}{l}\text { EPD/EMS identifier for the fraction of } \\
\text { the sample analyzed (see table C.8) }\end{array}$ \\
\hline Validation status & $220-221$ & Alphanumeric & $\begin{array}{l}0=\text { Unvalidated (used by laboratory) } \\
3=\text { Validated definitive data }\end{array}$ \\
\hline EPD/EMS receipt date & $222-227$ & Numeric & $\begin{array}{l}\text { Date that the analytical data are } \\
\text { received by EPD/EMS from the } \\
\text { laboratory. The laboratory leaves this } \\
\text { blank }\end{array}$ \\
\hline ESH-EMS number & $228-234$ & Alphanumeric & $\begin{array}{l}\text { Document number assigned to the } \\
\text { project report }\end{array}$ \\
\hline
\end{tabular}

Data Summary Report for the Annual Fourmile Branch and F- and H-Area Seeplines, Appendix IX Metals and Radionuclides, 1998 (WSRC-TR-98-00260) 
Table C.6 is a description of the analytical data format, AN95-R2.B which is used for coding and transmitting a subset of the AN95 analytical data records.

Table C.6 Analytical Data Format AN95-R2.B

\begin{tabular}{|c|c|c|c|}
\hline Name & Columns & Type & Description \\
\hline Station identifier & $1-11$ & Alphanumeric & $\begin{array}{l}\text { Identification of the actual sample } \\
\text { (includes any modification made in the } \\
\text { field) }\end{array}$ \\
\hline Top of interval & $12-17$ & Numeric & $\begin{array}{l}\text { Depth from the ground to the top of the } \\
\text { actual sampling interval to the nearest } \\
0.01 \mathrm{ft}\end{array}$ \\
\hline Bottom of interval & $18-23$ & Numeric & $\begin{array}{l}\text { Depth from the ground to the bottom of } \\
\text { the actual sampling interval to the } \\
\text { nearest } 0.01 \mathrm{ft}\end{array}$ \\
\hline Sample collection date & $24-30$ & Numeric & $\begin{array}{l}\text { Date sample was collected. Enter the } \\
\text { preparation date for laboratory blanks } \\
\text { and QC samples; enter the date of } \\
\text { completion of TCLP sample generation } \\
\text { for TCLP samples }\end{array}$ \\
\hline Laboratory replicate & $31-43$ & Alphanumeric & $\begin{array}{l}\text { Indicates that the sample is a non-blind } \\
\text { replicate analysis (see table C. } 7 \text { ) }\end{array}$ \\
\hline Analyte name & $44-8.3$ & Alphanumeric & Full analyte name \\
\hline Analysis type & $84-93$ & Alphanumeric & Analytical suite \\
\hline Quantitation limit & $95-102$ & Numeric & $\begin{array}{l}\text { GE and WA report the ssEQL for non- } \\
\text { radiochemistry analyses; all labs report } \\
\text { the MDA for radiochemistry analyses }\end{array}$ \\
\hline Result qualifier & $103-105$ & Alphanumeric & $\begin{array}{l}\text { Coded field used to qualify the analytical } \\
\text { result (see table D.1) }\end{array}$ \\
\hline Result & $106-115$ & Numeric & $\begin{array}{l}\text { Concentration of the analyte. For non- } \\
\text { detects, the ssEQL is reported. Results } \\
\text { are reported on a dry weight basis for all } \\
\text { analyses reported in per mass units }\end{array}$ \\
\hline Result unit & $116-121$ & Alpha & $\begin{array}{l}\text { Unit in which the analytical result is } \\
\text { reported }\end{array}$ \\
\hline Validation status & $122-123$ & Alphanumeric & $\begin{array}{l}0=\text { Unvalidated (used by laboratory) } \\
3=\text { Validated definitive data }\end{array}$ \\
\hline Document number & $124-130$ & Alphanumeric & $\begin{array}{l}\text { Document number assigned to the } \\
\text { project report }\end{array}$ \\
\hline
\end{tabular}


When making entries in the laboratory replicate field of the data files, only the codes listed in table C.7 are used.

Table C.7 Codes for Laboratory Replicates

\begin{tabular}{|l|l|}
\hline Remark & Definition \\
\hline (blank) & Data not remarked; the result is a routine analysis of a sample \\
\hline 1 & Laboratory replicate \\
\hline $2 \mathrm{~A}$ & Matrix spike \\
\hline $2 \mathrm{~B}$ & Matrix spike duplicate \\
\hline $2 \mathrm{C}$ & Surrogate spike \\
\hline $2 \mathrm{D}$ & Blank spike \\
\hline $2 \mathrm{E}$ & Blank spike duplicate \\
\hline 3 & Laboratory blank \\
\hline 4 & Re-analysis of a sample at the request of EPD/EMS \\
\hline CCB & Continuing calibration blank \\
\hline CCV & Continuing calibration verification sample \\
\hline ICB & Initial calibration blank \\
\hline ICS & Interference check sample \\
\hline ICV & Initial calibration verification sample \\
\hline
\end{tabular}

When making entries in the sample fraction field of the data files, only the codes listed in table C.8 are used.

Table C.8 Codes for Fractions

\begin{tabular}{|l|l|}
\hline Code & Description \\
\hline (blank) & Sample was not fractionated prior to analysis \\
\hline A & Ashed fraction \\
\hline D & Dried fraction of a soil or sludge sample; not used with water samples \\
\hline F & Liquid fraction passing through a filter was analyzed \\
\hline SL & Liquid fraction of a sample separated from the solid fraction \\
\hline SS & Suspended soils \\
\hline T & TCLP extraction \\
\hline
\end{tabular}




\section{D.1 Qualifiers}

The following qualifiers may have been applied to the analytical results during data validation.

Table D.1 Result Qualifiers

\begin{tabular}{|c|c|}
\hline Qualifier & Description \\
\hline (blank) & Data are not remarked. Values should be interpreted exactly as reported. \\
\hline $\mathrm{C}^{1}$ & $\begin{array}{l}\text { Calculated. Analytical result reported was not measured directly but was } \\
\text { calculated from other available data. This does not apply to conversions, nor does } \\
\text { it apply to calculations made as part of an analytical procedure. }\end{array}$ \\
\hline$D^{1}$ & Field measurement \\
\hline I & $\begin{array}{l}\text { The value in the result field is the instrument reading, not the sample quantitation } \\
\text { limit. Always used with the result qualifier } U \text {. }\end{array}$ \\
\hline $\mathrm{J}^{2}$ & The analytical result is an estimated quantity. \\
\hline $\mathrm{L}^{1}$ & $\begin{array}{l}\text { Off-scale high. The actual value is not known but is known to be greater than } \\
\text { value shown. }\end{array}$ \\
\hline $\mathrm{R}^{1}$ & $\begin{array}{l}\text { Result was rejected because performance requirements in the sample or associated } \\
\text { quality control analysis were not met. The analyte may or may not be present. }\end{array}$ \\
\hline $\mathrm{U}^{2}$ & $\begin{array}{l}\text { Material analyzed for but not detected. The analyte concentration is less than the } \\
\text { ssEQL. NOTE: When both the result qualifier } U \text { and the result qualifier } I \text { are } \\
\text { reported, the numerical value in the result field is the instrument reading rather } \\
\text { than the ssEQL. }\end{array}$ \\
\hline
\end{tabular}

Table D.2 Analysis Qualifiers

\begin{tabular}{|l|l|}
\hline Qualifier & Description \\
\hline A & $\begin{array}{l}\text { GCIMS Compound Identification } \\
\text { Relative retention time or mass spectra criteria were not met. } \\
\text { Compound Identification } \\
\text { All anomalies }\end{array}$ \\
\hline B & $\begin{array}{l}\text { The result is below the sample quantitation limit and above or equal to the } \\
\text { instrument detection limit. }\end{array}$ \\
\hline C & $\begin{array}{l}\text { Laboratory Control Sample } \\
\text { Criteria were not met. }\end{array}$ \\
\hline D & $\begin{array}{l}\text { ICP Serial Dilution } \\
\text { Criteria were not met. }\end{array}$ \\
\hline
\end{tabular}

1 This code is based on the STORET codes from the EPA.

2 This code is based on the CLP Laboratory Data Qualifiers from the EPA.

Data Summary Report for the Annual Fourmile Branch and 
Table D.2 Analysis Qualifiers (cont.)

\begin{tabular}{|c|c|}
\hline Qualifier & Description \\
\hline $\mathrm{E}$ & $\begin{array}{l}\text { The detected result is between the ssEQL and the method detection limit. Report } \\
\text { the actual result detected. }\end{array}$ \\
\hline F & $\begin{array}{l}\text { Pesticides Compound Identification } \\
\text { Pesticide result has been confirmed by gas chromatography/mass spectrometry. }\end{array}$ \\
\hline $\mathrm{G}$ & $\begin{array}{l}\text { Pesticides Instrument Performance } \\
\text { Use for all conditions outside criteria other than those flagged } N \text { (see code } N \\
\text { below). }\end{array}$ \\
\hline $\mathrm{H}$ & $\begin{array}{l}\text { Internal Standards Performance } \\
\text { Criteria were not met. }\end{array}$ \\
\hline I & $\begin{array}{l}\text { Matrix Spike/Matrix Spike Duplicate } \\
\text { Matrix Spike Sample Analysis } \\
\text { Spike recovery was not within control limits. }\end{array}$ \\
\hline $\mathrm{K}$ & $\begin{array}{l}\text { Tentatively Identified Compounds } \\
\text { A tentatively identified compound is a suspected aldol-condensation product. }\end{array}$ \\
\hline $\mathrm{L}$ & $\begin{array}{l}\text { Calibration Criteria Not Met } \\
\text { Calibration criteria (initial or continuing) were not met. See also } Z \text { for inorganics. }\end{array}$ \\
\hline $\mathrm{M}$ & $\begin{array}{l}\text { GC/MS Tuning } \\
\text { Mass calibration criteria were not met. }\end{array}$ \\
\hline $\mathrm{N}$ & $\begin{array}{l}\text { Tentatively Identified Compounds } \\
\text { All TIC results }\end{array}$ \\
\hline $\mathrm{O}$ & $\begin{array}{l}\text { Surrogate Recovery } \\
\text { Surrogate spike recovery results are not within control limits. }\end{array}$ \\
\hline $\mathrm{P}$ & $\begin{array}{l}\text { Furnace Atomic Absorption QC } \\
\text { Duplicate injection precision criteria were not met, or post-digestion spike recovery } \\
\text { was not within control limits, but sample absorbance is greater than } 50 \% \text { of post- } \\
\text { digestion spike absorbance. }\end{array}$ \\
\hline Q & $\begin{array}{l}\text { Holding Time } \\
\text { Sample held beyond normal holding time. }\end{array}$ \\
\hline $\mathrm{R}$ & $\begin{array}{l}\text { ICP Interference Check Sample } \\
\text { Criteria not met }\end{array}$ \\
\hline$S$ & The reported value was determined by the method of standard additions. \\
\hline V & $\begin{array}{l}\text { Method Blank Contamination } \\
\text { Indicates the analyte was detected in both the sample and associated method } \\
\text { blank. }\end{array}$ \\
\hline W & $\begin{array}{l}\text { Furnace Atomic Absorption QC } \\
\text { Post-digestion spike recovery for furnace atomic absorption analysis is not within } \\
\text { control limits while sample absorbance is less than } 50 \% \text { of spike absorbance. }\end{array}$ \\
\hline $\mathrm{X}$ & $\begin{array}{l}\text { Matrix Spike/Matrix Spike Duplicates } \\
\text { Laboratory Duplicate Sample Analysis } \\
\text { Duplicate analysis relative percent difference is not within control limits. }\end{array}$ \\
\hline $\mathrm{Y}$ & Result obtained from unpreserved or improperly preserved sample. \\
\hline
\end{tabular}

Data Summary Report for the Annual Fourmile Branch and F- and H-Area Seeplines, Appendix IX Metals and Radionuclides, 1998.

(WSRC-TR-98-00260) 
Table D.2 Analysis Qualifiers (cont.)

\begin{tabular}{|l|l|}
\hline Qualifier & Description \\
\hline$Z$ & $\begin{array}{l}\text { Calibration } \\
\text { Furnace Atomic Absorption } \mathbf{Q C} \\
\text { Correlation coefficient was less than } 0.995 .\end{array}$ \\
\hline 4 & $\begin{array}{l}\text { Tatrix interference; value cannot be determined. } \\
\text { percent recovery cannot be determined. }\end{array}$ \\
\hline 5 & The analyte was detected in both the sample and associated field blank. \\
\hline 6 & $\begin{array}{l}\text { The analyte was detected in both the sample and associated rinsate or equipment } \\
\text { blank. }\end{array}$ \\
\hline 7 & The analyte was detected in both the sample and associated trip blank. \\
\hline 8 & $\begin{array}{l}\text { Field Duplicate Sample Analysis } \\
\text { Duplicate analysis relative percent difference is not within control limits. }\end{array}$ \\
\hline 9 & Bas Qualfand
\end{tabular}

Table D.3 Bias Qualifiers

\begin{tabular}{|l|l|}
\hline Qualifier & Description \\
\hline $\mathrm{L}$ & $\begin{array}{l}\text { Analytical factor causing bias. The associated result may underestimate the true } \\
\text { value. }\end{array}$ \\
\hline $\mathrm{H}$ & $\begin{array}{l}\text { Analytical factor causing bias. The associated result may overestimate the true } \\
\text { value. }\end{array}$ \\
\hline
\end{tabular}

\section{D.2 Data Summaries}

Table D.4 Number of Analytical Records by Method and Type of Record

Table D.5 Analytes Not Detected in Background Water Samples

Table D.6 Analytes Detected in Background Water Samples

Table D.7 Analytes Not Detected in Routine Water Samples

Table D.8 Analytes Detected in Routine Water Samples

Table D.9 Results Sorted By Sample

Table D.10 Blank Results Sorted by Sample

Table D.11 Sample Results Sorted by Analyte

Table D.12 Blank Results Sorted by Analyte 
Table D.4 Number of Analytical Records by Method and Type of Record

\begin{tabular}{|l|l|l|l|l|l|l|}
\hline Method & $\begin{array}{l}\text { Sample } \\
\text { Records }\end{array}$ & $\begin{array}{l}\text { Laboratory } \\
\text { Duplicates }\end{array}$ & $\begin{array}{l}\text { Laboratory } \\
\text { Blanks }\end{array}$ & $\begin{array}{l}\text { Matrix } \\
\text { Spike } \\
\text { Duplicates }\end{array}$ & $\begin{array}{l}\text { Calibration } \\
\text { Checks }\end{array}$ & Totals \\
\hline 3500NIEMOD & 1 & 1 & 1 & 0 & 0 & 3 \\
\hline EMLSR02MOD & 1 & 1 & 1 & 0 & 0 & 3 \\
\hline EPA130.2 & 21 & 4 & 4 & 5 & 0 & 34 \\
\hline EPA300.0 & 38 & 8 & 8 & 8 & 0 & 62 \\
\hline EPA335.3 & 21 & 2 & 2 & 2 & 0 & 27 \\
\hline EPA353.1 & 19 & 1 & 4 & 1 & 0 & 25 \\
\hline EPA353.2 & 4 & 0 & 2 & 0 & 0 & 6 \\
\hline EPA6010 & 46 & 0 & 23 & 0 & 0 & 69 \\
\hline EPA6010A & 483 & 0 & 116 & 186 & 0 & 785 \\
\hline EPA7470 & 23 & 1 & 6 & 6 & 14 & 50 \\
\hline EPA900.0MOD & 4 & 2 & 2 & 0 & 0 & 8 \\
\hline EPA901.1MOD & 48 & 24 & 2 & 0 & 0 & 74 \\
\hline EPA9010A & 2 & 1 & 1 & 2 & 0 & 6 \\
\hline EPA902.0MOD & 1 & 1 & 1 & 0 & 0 & 3 \\
\hline EPA904.0MOD & 1 & 1 & 1 & 0 & 0 & 3 \\
\hline EPA9056 & 2 & 0 & 1 & 0 & 0 & 3 \\
\hline EPA906.0 & 19 & 0 & 3 & 0 & 0 & 22 \\
\hline EPA906.0MOD & 2 & 1 & 1 & 0 & 0 & 4 \\
\hline EPIA-001 & 42 & 0 & 10 & 0 & 0 & 52 \\
\hline EPIA-006 & 4 & 2 & 3 & 2 & 0 & 11 \\
\hline EPIA-008 & 6 & 2 & 3 & 2 & 0 & 13 \\
\hline EPIA-009 & 4 & 1 & 3 & 1 & 0 & 9 \\
\hline EPIA-011 & 42 & 7 & 14 & 3 & 0 & 66 \\
\hline EPIA-013 & 525 & 50 & 50 & 2 & 0 & 627 \\
\hline EPIA-022 & 4 & 1 & 3 & 1 & 0 & 9 \\
\hline EPIA-032 & 6 & 1 & 2 & 1 & 0 & 10 \\
\hline & & & & & & \\
\hline
\end{tabular}


Table D.5 Analytes Not Detected in Background Water Samples

\begin{tabular}{|l|l|l|}
\hline Analyte & Min/Max ssMDLs & Unit \\
\hline Actinium-228 & $1.84 \mathrm{E}+01 / 3.05 \mathrm{E}+01$ & $\mathrm{pCi} / \mathrm{L}$ \\
\hline Antimony & $1.64 / 1.64$ & $\mu \mathrm{g} / \mathrm{L}$ \\
\hline Antimony-124 & $5.17 \mathrm{E}+00 / 7.68 \mathrm{E}+00$ & $\mathrm{pCi} / \mathrm{L}$ \\
\hline Antimony-125 & $1.07 \mathrm{E}+01 / 1.69 \mathrm{E}+01$ & $\mathrm{pCi} / \mathrm{L}$ \\
\hline Arsenic & $2.98 / 2.98$ & $\mu \mathrm{g} / \mathrm{L}$ \\
\hline Barium-133 & $5.11 \mathrm{E}+00 / 7.20 \mathrm{E}+00$ & $\mathrm{pCi} / \mathrm{L}$ \\
\hline Beryllium & $0.223 / 0.223$ & $\mu \mathrm{g} / \mathrm{L}$ \\
\hline Cadmium & $0.208 / 0.208$ & $\mu \mathrm{g} / \mathrm{L}$ \\
\hline Cerium-144 & $2.43 \mathrm{E}+01 / 3.65 \mathrm{E}+01$ & $\mathrm{pCi} / \mathrm{L}$ \\
\hline Cesium-134 & $4.37 \mathrm{E}+00 / 6.48 \mathrm{E}+00$ & $\mathrm{pCi} / \mathrm{L}$ \\
\hline Cesium-137 & $4.08 \mathrm{E}+00 / 7.34 \mathrm{E}+00$ & $\mathrm{pCi} / \mathrm{L}$ \\
\hline Chromium & $0.729 / 0.729$ & $\mu \mathrm{g} / \mathrm{L}$ \\
\hline Cobalt & $0.671 / 0.671$ & $\mu \mathrm{g} / \mathrm{L}$ \\
\hline Cobalt-57 & $3.14 \mathrm{E}+00 / 4.86 \mathrm{E}+00$ & $\mathrm{pCi} / \mathrm{L}$ \\
\hline Cobalt-58 & $4.57 \mathrm{E}+00 / 6.84 \mathrm{E}+00$ & $\mathrm{pCi} / \mathrm{L}$ \\
\hline Cobalt-60 & $4.60 \mathrm{E}+00 / 7.11 \mathrm{E}+00$ & $\mathrm{pCi} / \mathrm{L}$ \\
\hline Copper & $1.32 / 1.32$ & $\mu \mathrm{g} / \mathrm{L}$ \\
\hline Curium-242 & $1.18 \mathrm{E}-01 / 1.18 \mathrm{E}-01$ & $\mathrm{pCi} / \mathrm{L}$ \\
\hline Curium-245/246 & $4.57 \mathrm{E}-02 / 4.57 \mathrm{E}-02$ & $\mathrm{pCi} / \mathrm{L}$ \\
\hline Cyanide & $3.34 / 3.34$ & $\mu \mathrm{g} / \mathrm{L}$ \\
\hline Europium-152 & $1.13 \mathrm{E}+01 / 1.83 \mathrm{E}+01$ & $\mathrm{pCi} / \mathrm{L}$ \\
\hline Europium-154 & $1.12 \mathrm{E}+01 / 1.94 \mathrm{E}+01$ & $\mathrm{pCi} / \mathrm{L}$ \\
\hline Europium-155 & $1.32 \mathrm{E}+01 / 1.99 \mathrm{E}+01$ & $\mathrm{pCi} / \mathrm{L}$ \\
\hline Lead & $0.678 / 0.678$ & $\mu \mathrm{g} / \mathrm{L}$ \\
\hline Manganese-54 & $4.28 \mathrm{E}+00 / 6.65 \mathrm{E}+00$ & $\mathrm{pCi} / \mathrm{L}$ \\
\hline Mercury & $0.104 / 0.104$ & $\mu \mathrm{g} / \mathrm{L}$ \\
\hline Neptunium-237 & $1.49 \mathrm{E}-01 / 1.49 \mathrm{E}-01$ & $\mathrm{pCi} / \mathrm{L}$ \\
\hline Neptunium-239 & $2.30 \mathrm{E}+01 / 3.53 \mathrm{E}+01$ & $\mathrm{pCi} / \mathrm{L}$ \\
\hline Promethium-144 & $4.22 \mathrm{E}+00 / 7.06 \mathrm{E}+00$ & $\mathrm{pCi} / \mathrm{L}$ \\
\hline Promethium-146 & $5.17 \mathrm{E}+00 / 8.83 \mathrm{E}+00$ & $\mathrm{pCi} / \mathrm{L}$ \\
\hline Ruthenium-106 & $3.75 \mathrm{E}+01 / 6.46 \mathrm{E}+01$ & $\mathrm{pCi} / \mathrm{L}$ \\
\hline Selenium & $1.4 / 1.4$ & $\mu \mathrm{g} / \mathrm{L}$ \\
\hline Silver & $0.62 / 0.62$ & $\mu \mathrm{g} / \mathrm{L}$ \\
\hline Sodium-22 & $4.03 \mathrm{E}+00 / 6.93 \mathrm{E}+00$ & $\mathrm{pCi} / \mathrm{L}$ \\
\hline Thallium & $2.63 / 2.63$ & $\mu \mathrm{g} / \mathrm{L}$ \\
\hline Tin & $2.94 / 2.94$ & $\mu \mathrm{g} / \mathrm{L}$ \\
\hline Tin-113 & $5.40 \mathrm{E}+00 / 8.32 \mathrm{E}+00$ & $\mathrm{pCi} / \mathrm{L}$ \\
\hline Uranium-235 & $2.85 \mathrm{E}-01 / 2.85 \mathrm{E}-01$ & $\mathrm{pCi} / \mathrm{L}$ \\
\hline Yttrium-88 & $4.85 \mathrm{E}+00 / 8.03 \mathrm{E}+00$ & $\mathrm{pCi} / \mathrm{L}$ \\
\hline & & \\
\hline
\end{tabular}

Data Summary Report for the Annual Fourmile Branch and

F- and H-Area Seeplines, Appendix IX Metals and Radionuclides, 1998

(WSRC-TR-98-00260) 
Table D.5 Analytes Not Detected in Background Water Samples (cont.)

\begin{tabular}{|l|l|l|}
\hline Analyte & Min/Max ssMDLs & Unit \\
\hline Zinc-65 & $8.77 \mathrm{E}+00 / 1.36 \mathrm{E}+01$ & $\mathrm{pCi} / \mathrm{L}$ \\
\hline Zirconium-95 & $8.45 \mathrm{E}+00 / 1.16 \mathrm{E}+01$ & $\mathrm{pCi} / \mathrm{L}$ \\
\hline
\end{tabular}


Table D.6 Analytes Detected in Background Water Samples

\begin{tabular}{|l|l|l|l|}
\hline Analyte & Avg Result & Min/Max Results & Unit \\
\hline Aluminum & 274 & $174 / 453$ & $\mu \mathrm{g} / \mathrm{L}$ \\
\hline Americium-241 & $7.81 \mathrm{E} \cdot 01$ & $7.81 \mathrm{E}-01 / 7.81 \mathrm{E}-01$ & $\mathrm{pCi} / \mathrm{L}$ \\
\hline Barium & 17.1 & $11.8 / 24$ & $\mu \mathrm{g} / \mathrm{L}$ \\
\hline Calcium & 725 & $410 / 1020$ & $\mu \mathrm{g} / \mathrm{L}$ \\
\hline Chloride & 1860 & $1460 / 2380$ & $\mu \mathrm{g} / \mathrm{L}$ \\
\hline Curium-243/244 & $1.53 \mathrm{E}-01$ & $1.53 \mathrm{E}-01 / 1.53 \mathrm{E}-01$ & $\mathrm{pCi} / \mathrm{L}$ \\
\hline Gross alpha & $9.40 \mathrm{E}+00$ & $8.28 \mathrm{E}-01 / 3.13 \mathrm{E}+01$ & $\mathrm{pCi} / \mathrm{L}$ \\
\hline Hardness as CACO3 & 11200 & $6000 / 16000$ & $\mu \mathrm{g} / \mathrm{L}$ \\
\hline Iron & 1110 & $83.8 / 2360$ & $\mu \mathrm{g} / \mathrm{L}$ \\
\hline Lead-212 & $2.09 \mathrm{E}+01$ & $1.24 \mathrm{E}+01 / 2.93 \mathrm{E}+01$ & $\mathrm{pCi} / \mathrm{L}$ \\
\hline Magnesium & 396 & $288 / 458$ & $\mu \mathrm{g} / \mathrm{L}$ \\
\hline Manganese & 56.6 & $19.8 / 97.2$ & $\mu \mathrm{g} / \mathrm{L}$ \\
\hline Nickel & 3.36 & $3.36 / 3.36$ & $\mu \mathrm{g} / \mathrm{L}$ \\
\hline Nitrate as nitrogen & 192 & $102 / 309$ & $\mu \mathrm{g} / \mathrm{L}$ \\
\hline Nitrate-nitrite as nitrogen & 205 & $90 / 320$ & $\mu \mathrm{g} / \mathrm{L}$ \\
\hline Nonvolatile beta & $7.78 \mathrm{E}+00$ & $1.01 \mathrm{E}+00 / 1.79 \mathrm{E}+01$ & $\mathrm{pCi} / \mathrm{L}$ \\
\hline Potassium & 146 & $69.9 / 273$ & $\mu \mathrm{g} / \mathrm{L}$ \\
\hline Potassium-40 & $8.89 \mathrm{E}+01$ & $8.89 \mathrm{E}+01 / 8.89 \mathrm{E}+01$ & $\mathrm{pCi} / \mathrm{L}$ \\
\hline Radium-226 & $3.03 \mathrm{E}+00$ & $2.76 \mathrm{E}+00 / 3.29 \mathrm{E}+00$ & $\mathrm{pCi} / \mathrm{L}$ \\
\hline Sodium & 1240 & $927 / 1650$ & $\mu \mathrm{g} / \mathrm{L}$ \\
\hline Tritium & 2.12 & $0.734 / 4.15$ & $\mathrm{pCi} / \mathrm{mL}$ \\
\hline Uranium-233/234 & $1.29 \mathrm{E}+00$ & $1.29 \mathrm{E}+00 / 1.29 \mathrm{E}+00$ & $\mathrm{pCi} / \mathrm{L}$ \\
\hline Uranium-238 & $9.87 \mathrm{E}-01$ & $9.87 \mathrm{E}-01 / 9.87 \mathrm{E}-01$ & $\mathrm{pCi} / \mathrm{L}$ \\
\hline Vanadium & 1.57 & $1.57 / 1.57$ & $\mu \mathrm{g} / \mathrm{L}$ \\
\hline Zinc & 5.88 & $5.88 / 5.88$ & $\mu \mathrm{g} / \mathrm{L}$ \\
\hline
\end{tabular}

Data Summary Report for the Annual Fourmile Branch and 
Table D.7 Analytes Not Detected in Routine Water Samples

\begin{tabular}{|c|c|c|}
\hline Analyte & Min/Max ssMDLs & Unit \\
\hline Antimony & $1.64 / 3.28$ & $\mu \mathrm{g} / \mathrm{L}$ \\
\hline Antimony 124 & $3.42 \mathrm{E}+00 / 6.15 \mathrm{E}+00$ & $\mathrm{pCi} / \mathrm{L}$ \\
\hline Antimony 125 & $8.09 \mathrm{E}+00 / 1.42 \mathrm{E}+01$ & $\mathrm{pCi} / \mathrm{L}$ \\
\hline Arsenic & $2.98 / 5.96$ & $\mu \mathrm{g} / \mathrm{L}$ \\
\hline Barium-133 & $3.38 \mathrm{E}+00 / 6.42 \mathrm{E}+00$ & $\mathrm{pCi} / \mathrm{L}$ \\
\hline Cerium-144 & $2.03 \mathrm{E}+01 / 2.97 \mathrm{E}+01$ & $\mathrm{pCi} / \mathrm{L}$ \\
\hline Cesium-134 & 3.10E+00/5.02E+00 & $\mathrm{pCi} / \mathrm{L}$ \\
\hline Cesium-137 & $2.91 \mathrm{E}+00 / 6.20 \mathrm{E}+00$ & $\mathrm{pCi} / \mathrm{L}$ \\
\hline Cobalt -57 & $2.61 \mathrm{E}+00 / 3.54 \mathrm{E}+00$ & $\mathrm{pCi} / \mathrm{L}$ \\
\hline Cobalt -58 & $3.12 \mathrm{E}+00 / 6.17 \mathrm{E}+00$ & $\mathrm{pCi} / \mathrm{L}$ \\
\hline Curium-242 & 3.79E-02/3.20E-01 & $\mathrm{pCi} / \mathrm{L}$ \\
\hline Curium-245/246 & $3.06 \mathrm{E}-02 / 1.04 \mathrm{E}-01$ & $\mathrm{pCi} / \mathrm{L}$ \\
\hline Cyanide & $3.34 / 3.34$ & $\mu \mathrm{g} / \mathrm{L}$ \\
\hline Europium-152 & $7.93 \mathrm{E}+00 / 1.47 \mathrm{E}+01$ & $\mathrm{pCi} / \mathrm{L}$ \\
\hline Europium-154 & $7.30 \mathrm{E}+00 / 1.65 \mathrm{E}+01$ & $\mathrm{pCi} / \mathrm{L}$ \\
\hline Europium-155 & $1.10 \mathrm{E}+01 / 1.58 \mathrm{E}+01$ & $\mathrm{pCi} / \mathrm{L}$ \\
\hline Manganese -54 & $2.14 \mathrm{E}+00 / 5.83 \mathrm{E}+00$ & $\mathrm{pCi} / \mathrm{L}$ \\
\hline Mercury & $0.104 / 0.104$ & $\mu \mathrm{g} / \mathrm{L}$ \\
\hline Neptunium.239 & $1.87 \mathrm{E}+01 / 2.68 \mathrm{E}+01$ & $\mathrm{pCi} / \mathrm{L}$ \\
\hline Nickel-6:3 & $2.20 \mathrm{E}+02 / 2.55 \mathrm{E}+02$ & $\mathrm{pCi} / \mathrm{L}$ \\
\hline Promethium-144 & $2.69 \mathrm{E}+00 / 5.39 \mathrm{E}+00$ & $\mathrm{pCi} / \mathrm{L}$ \\
\hline Promethium-146 & $3.43 \mathrm{E}+00 / 6.64 \mathrm{E}+00$ & $\mathrm{pCi} / \mathrm{L}$ \\
\hline Ruthenium-106 & $2.51 \mathrm{E}+01 / 5.05 \mathrm{E}+01$ & $\mathrm{pCi} / \mathrm{L}$ \\
\hline Selenium & $1.4 / 2.8$ & $\mu \mathrm{g} / \mathrm{L}$ \\
\hline Silver & $0.62 / 1.24$ & $\mu \mathrm{g} / \mathrm{L}$ \\
\hline Sodium-22 & $2.62 \mathrm{E}+00 / 5.92 \mathrm{E}+00$ & $\mathrm{pCi} / \mathrm{L}$ \\
\hline Thallium & $2.63 / 5.26$ & $\mu g / L$ \\
\hline Tin & $2.94 / 5.88$ & $\mu \mathrm{g} / \mathrm{L}$ \\
\hline Tin-113 & $3.52 \mathrm{E}+00 / 6.61 \mathrm{E}+00$ & $\mathrm{pCi} / \mathrm{L}$ \\
\hline Uranium-235 & $1.05 \mathrm{E}-01 / 2.18 \mathrm{E}-01$ & $\mathrm{pCi} / \mathrm{L}$ \\
\hline Yttrium-88 & $3.84 \mathrm{E}+00 / 7.36 \mathrm{E}+00$ & $\mathrm{pCi} / \mathrm{L}$ \\
\hline Zinc -65 & $5.67 \mathrm{E}+00 / 1.31 \mathrm{E}+01$ & $\mathrm{pCi} / \mathrm{L}$ \\
\hline Zirconium-95 & $5.80 \mathrm{E}+00 / 1.00 \mathrm{E}+01$ & $\mathrm{pCi} / \mathrm{L}$ \\
\hline
\end{tabular}

Data Summary Report for the Annual Fourmile Branch and

F-and H-Area Seeplines, Appendix IX Metals and Radionuclides, 1998

(WSRC-TR-98-00260) 
Table D.8 Analytes Detected in Routine Water Samples

\begin{tabular}{|c|c|c|c|}
\hline Analyte & Avg Result & Min/Max Results & Unit \\
\hline Actinium-228 & $2.55 \mathrm{E}+01$ & $2.44 \mathrm{E}+01 / 2.66 \mathrm{E}+01$ & $\mathrm{pCi} / \mathrm{L}$ \\
\hline Aluminum & 3210 & $145 / 13100$ & $\mu \mathrm{g} / \mathrm{L}$ \\
\hline Americium-241 & $2.36 \mathrm{E}-01$ & $1.17 \mathrm{E}-01 / 3.55 \mathrm{E}-01$ & $\mathrm{pCi} / \mathrm{L}$ \\
\hline Barium & 69.9 & $14.1 / 216$ & $\mu \mathrm{g} / \mathrm{L}$ \\
\hline Beryllium & 1.26 & $0.737 / 1.78$ & $\mu \mathrm{g} / \mathrm{L}$ \\
\hline Cadmium & 1.98 & $0.678 / 3.13$ & $\mu \mathrm{g} / \mathrm{L}$ \\
\hline Calcium & 1450 & $355 / 4620$ & $\mu \mathrm{g} / \mathrm{L}$ \\
\hline Chloride & 2260 & $1380 / 4090$ & $\mu \mathrm{g} / \mathrm{L}$ \\
\hline Chromium & 3.63 & $1.07 / 8.58$ & $\mu \mathrm{g} / \mathrm{L}$ \\
\hline Cobalt & 6.73 & $0.741 / 28.4$ & $\mu \mathrm{g} / \mathrm{L}$ \\
\hline Cobalt -60 & $3.74 E+01$ & $3.64 \mathrm{E}+01 / 3.83 \mathrm{E}+01$ & $\mathrm{pCi} / \mathrm{L}$ \\
\hline Copper & 3.36 & $1.54 / 4.82$ & $\mu g / \mathrm{L}$ \\
\hline Curium $\cdot 243 / 244$ & $3.07 \mathrm{E}-01$ & $3.07 \mathrm{E}-01 / 3.07 \mathrm{E}-01$ & $\mathrm{pCi} / \mathrm{L}$ \\
\hline Gross alpha & $1.34 \mathrm{E}+01$ & $1.19 \mathrm{E}+00 / 4.82 \mathrm{E}+01$ & $\mathrm{pCi} / \mathrm{L}$ \\
\hline Hardness as CACO 3 & 13700 & $4000 / 67000$ & $\mu \mathrm{g} / \mathrm{L}$ \\
\hline Iodine -129 & $4.19 \mathrm{E}+00$ & $1.58 \mathrm{E}+00 / 8.71 \mathrm{E}+00$ & $\mathrm{pCi} / \mathrm{L}$ \\
\hline Iron & 2550 & $217 / 8430$ & $\mu \mathrm{g} / \mathrm{L}$ \\
\hline Lead & 7.28 & $1.09 / 18.7$ & $\mu \mathrm{g} / \mathrm{L}$ \\
\hline Lead.212 & $8.89 \mathrm{E}+00$ & $6.97 \mathrm{E}+00 / 1.08 \mathrm{E}+01$ & $\mathrm{pCi} / \mathrm{L}$ \\
\hline Magnesium & 808 & $348 / 2640$ & $\mu \mathrm{g} / \mathrm{L}$ \\
\hline Manganese & $3: 38$ & $19.4 / 1140$ & $\mu \mathrm{g} / \mathrm{L}$ \\
\hline Neptunium-2:37 & $1.71 \mathrm{E}-01$ & $9.39 \mathrm{E}-02 / 3.22 \mathrm{E}-01$ & $\mathrm{pCi} / \mathrm{L}$ \\
\hline Nickel & 8.69 & $3.54 / 17.8$ & $\mu \mathrm{g} / \mathrm{L}$ \\
\hline Nitrate as nitrogen & 2930 & $16: 3 / 34200$ & $\mu \mathrm{g} / \mathrm{L}$ \\
\hline Nitrate-nitrite as nitrogen & 4250 & $80 / 35800$ & $\mu \mathrm{g} / \mathrm{L}$ \\
\hline Nonvolatile beta & $1.01 \mathrm{E}+02$ & $3.58 \mathrm{E}+00 / 4.82 \mathrm{E}+02$ & $\mathrm{pCi} / \mathrm{L}$ \\
\hline Potassium & 345 & $37.8 / 880$ & $\mu \mathrm{g} / \mathrm{L}$ \\
\hline Potassium.40 & $6.47 \mathrm{E}+01$ & $6.47 \mathrm{E}+01 / 6.47 \mathrm{E}+01$ & $\mathrm{pCi} / \mathrm{L}$ \\
\hline Radium-226 & $5.43 \mathrm{E}+00$ & $6.67 \mathrm{E}-01 / 1.48 \mathrm{E}+01$ & $\mathrm{pCi} / \mathrm{L}$ \\
\hline Radium-228 & $2.64 \mathrm{E}+00$ & $2.64 \mathrm{E}+00 / 2.64 \mathrm{E}+00$ & $\mathrm{pCi} / \mathrm{L}$ \\
\hline Sodium & 7800 & $1480 / 25400$ & $\mu \mathrm{g} / \mathrm{L}$ \\
\hline Tritium & 334 & $6.66 / 1720$ & $\mathrm{pCi} / \mathrm{mL}$ \\
\hline Uranium-23:3/234 & $7.36 \mathrm{E}-01$ & $2.18 \mathrm{E} \cdot 01 / 2.81 \mathrm{E}+00$ & $\mathrm{pCi} / \mathrm{L}$ \\
\hline Uranium $\cdot 238$ & $8.70 \mathrm{E}-01$ & $1.70 \mathrm{E} \cdot 01 / 2.64 \mathrm{E}+00$ & $\mathrm{pCi} / \mathrm{L}$ \\
\hline Vanadium & 5.2 & $0.977 / 18.4$ & $\mu \mathrm{g} / \mathrm{L}$ \\
\hline Zinc & 19.6 & $8.53 / 35.7$ & $\mu \mathrm{g} / \mathrm{L}$ \\
\hline
\end{tabular}

Data Summary Report for the Annual Fourmile Branch and

F- and H-Area Seeplines, Appendix IX Metals and Radionuclides, 1998

(WSRC-TR-98-00260) 


\section{D.3 Results Sorted by Sample}

\section{Table D.9 Results Sorted By Sample}

SURVEY ID: BG 00103

Sample ID: 114003

Survey location: 59153E $67208 \mathrm{~N}$ (SRS coordinates)

Ground elevation above MSL: . ft

Sample type: Normal

Sample matrix: Water

Constituent

Specified Analyses

Chloride

Chloride

Cyanide

Hardness as $\mathrm{CACO} 3$

Nitrate as nitrogen

Nitrate as nitrogen

Nitrate-nitrite as nitrogen

Metals (total recoverable)
RQ AQ B Result

$\begin{array}{cccc} & \text { V } & & 1460 \\ & V & & 1610 \\ \text { UJ } & \text { I } & \text { L } & 10 \\ & & 11000 \\ \text { V } & & 302 \\ & \text { V } & 309 \\ & & 320\end{array}$

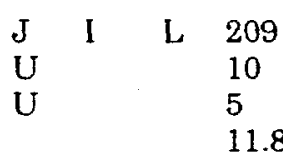

U $\quad 5$

U 5

U $\quad 5$

U $\quad 5$

Copper

Iron

Lead

Magnesium

Manganese

Mercury

Nickel

Potassium

Selenium

Silver

Sodium

Thallium

Tin

Vanadium

Zinc

Radionuclides

Actinium-228

Antimony-124

Antimony-125

Barium-133

Cerium-144

Cesium-134

Cesium-137

Cobalt-57

$\begin{array}{ll}\text { UI } & 1.15 \mathrm{E}+01 \\ \text { UI } & -3.38 \mathrm{E}-01 \\ \text { UI } & 6.49 \mathrm{E}+00 \\ \text { UI } & 4.28 \mathrm{E}-01 \\ \text { UI } & 2.94 \mathrm{E}-01 \\ \text { UI } & -1.67 \mathrm{E}+00 \\ \text { UI } & -2.51 \mathrm{E}+00 \\ \text { UI } & 1.26 \mathrm{E}+00\end{array}$

Unit ssMDL Method

$\begin{array}{lll}\mu \mathrm{g} / \mathrm{L} & 7 & \text { EPA300.0 } \\ \mu \mathrm{g} / \mathrm{L} & 7 & \text { EPA300.0 } \\ \mu \mathrm{g} / \mathrm{L} & 3.34 & \text { EPA335.3 } \\ \mu \mathrm{g} / \mathrm{L} & 1000 & \text { EPA130.2 } \\ \mu \mathrm{g} / \mathrm{L} & 6 & \text { EPA300.0 } \\ \mu \mathrm{g} / \mathrm{L} & 6 & \text { EPA300.0 } \\ \mu \mathrm{g} / \mathrm{L} & 7 & \text { EPA353.1 }\end{array}$

$\mu \mathrm{g} / \mathrm{L} \quad 37.6 \quad$ EPA6010A

$\mu \mathrm{g} / \mathrm{L} \quad 1.64 \quad$ EPA6010A

$\mu \mathrm{g} / \mathrm{L} \quad 2.98 \quad$ EPA6010A

$\mu \mathrm{g} / \mathrm{L} \quad 0.332 \quad$ EPA6010A

$\mu \mathrm{g} / \mathrm{L} \quad 0.223 \quad$ EPA6010A

$\mu \mathrm{g} / \mathrm{L} \quad 0.208 \quad$ EPA6010A

$\mu \mathrm{g} / \mathrm{L} \quad 15.4 \quad$ EPA6010A

$\mu \mathrm{g} / \mathrm{L} \quad 0.729 \quad$ EPA6010A

$\mu \mathrm{g} / \mathrm{L} \quad 0.671 \quad$ EPA6010A

$\mu \mathrm{g} / \mathrm{L} \quad 1.32 \quad$ EPA6010A

$\mu \mathrm{g} / \mathrm{L} \quad 8.63 \quad$ EPA6010A

$\mu \mathrm{g} / \mathrm{L} \quad 0.678 \quad$ EPA6010A

$\mu \mathrm{g} / \mathrm{L} \quad 3.33 \quad$ EPA6010A

$\mu \mathrm{g} / \mathrm{L} \quad 0.903 \quad$ EPA6010A

$\mu \mathrm{g} / \mathrm{L} \quad 0.104 \quad \mathrm{EPA7470}$

$\mu \mathrm{g} / \mathrm{L} \quad 2.27 \quad$ EPA6010A

$\mu \mathrm{g} / \mathrm{L} \quad 5.87$ EPA6010A

$\mu \mathrm{g} / \mathrm{L} \quad 1.4 \quad$ EPA6010A

$\mu \mathrm{g} / \mathrm{L} \quad 0.62 \quad$ EPA6010A

$\mu \mathrm{g} / \mathrm{L} \quad 29.1 \quad$ EPA6010A

$\mu \mathrm{g} / \mathrm{L} \quad 2.63 \quad$ EPA6010A

$\mu \mathrm{g} / \mathrm{L} \quad 2.94 \quad$ EPA6010A

$\mu \mathrm{g} / \mathrm{L} \quad 0.427 \quad$ EPA6010A

$\mu \mathrm{g} / \mathrm{L} \quad 0.966 \quad$ EPA6010A 
SURVEY ID: BG 00103 (cont.)

Constituent

Radionuclides

$\begin{array}{lcc}\text { Cobalt-58 } & \text { UI } & 1.66 \mathrm{E}+00 \\ \text { Cobalt-60 } & \text { UI } & 1.38 \mathrm{E}+00 \\ \text { Europium-152 } & \text { UI } & 4.25 \mathrm{E}-02 \\ \text { Europium-154 } & \text { UI } & -2.72 \mathrm{E}-01 \\ \text { Europium-155 } & \text { UI } & 4.17 \mathrm{E}+00 \\ \text { Gross alpha } & & 4.61 \mathrm{E}+00 \\ \text { Lead-212 } & \text { UI } & 2.44 \mathrm{E}+00 \\ \text { Manganese-54 } & \text { UI } & 5.04 \mathrm{E}-02 \\ \text { Neptunium-239 } & \text { UI } & 7.39 \mathrm{E}+00 \\ \text { Nonvolatile beta } & & 4.43 \mathrm{E}+00 \\ \text { Potassium-40 } & \text { UI } & 8.24 \mathrm{E}+00 \\ \text { Promethium-144 } & \text { UI } & -1.79 \mathrm{E}-01 \\ \text { Promethium-146 } & \text { UI } & 1.79 \mathrm{E}+00 \\ \text { Ruthenium-106 } & \text { UI } & -1.24 \mathrm{E}+01 \\ \text { Sodium-22 } & \text { UI } & -9.05 \mathrm{E}-02 \\ \text { Tin-113 } & \text { UI } & 1.32 \mathrm{E}+00 \\ \text { Tritium } & & 4.15 \mathrm{E}+00 \\ \text { Yttrium-88 } & \text { UI } & -8.84 \mathrm{E}-01 \\ \text { Zinc-65 } & \text { UI } & -1.48 \mathrm{E}+00 \\ \text { Zirconium-95 } & \text { UI } & 2.87 \mathrm{E}+00\end{array}$

SURVEY ID: BG 00203
Sample ID: 114003

RQ AQ B Result

Unit ssMDL Method

$\mathrm{pCi} / \mathrm{L} \quad 4.73 \mathrm{E}+00$ EPIA-013

$\mathrm{pCi} / \mathrm{L} \quad 4.80 \mathrm{E}+00$ EPIA-013

$\mathrm{pCi} / \mathrm{L} \quad 1.23 \mathrm{E}+01$ EPIA-013

$\mathrm{pCi} / \mathrm{L}$ 1.12E+01 EPIA-013

$\mathrm{pCi} / \mathrm{L} \quad 1.34 \mathrm{E}+01$ EPIA-013

$\mathrm{pCi} / \mathrm{L}$ 6.41E-01 EPIA-001

$\mathrm{pCi} / \mathrm{L} \quad 6.43 \mathrm{E}+00$ EPIA-013

$\mathrm{pCi} / \mathrm{L} \quad 4.52 \mathrm{E}+00$ EPIA-013

$\mathrm{pCi} / \mathrm{L} \quad 2.44 \mathrm{E}+01$ EPIA-013

$\mathrm{pCi} / \mathrm{L}$ 1.13E+00 EPIA-001

$\mathrm{pCi} / \mathrm{L}$ 4.21E+01 EPIA-013

$\mathrm{pCi} / 4.22 \mathrm{E}+00$ EPIA-013

$\mathrm{pCi} / \mathrm{L} \quad 6.01 \mathrm{E}+00$ EPIA-013

pCi/L 3.75E+01 EPIA-013

$\mathrm{pCi} / \mathrm{L}$ 4.03E+00 EPIA-013

$\mathrm{pCi} / \mathrm{L} \quad 5.70 \mathrm{E}+00$ EPIA-013

pCi/mL5.65E-01 EPA906.0

$\mathrm{pCi} / \mathrm{L} \quad 4.85 \mathrm{E}+00$ EPIA-013

$\mathrm{pCi} / \mathrm{L} \quad 1.01 \mathrm{E}+01$ EPIA-013

pCi/L $9.73 E+00$ EPIA-013

Survey location: 59363E 67229N (SRS coordinates)

Ground elevation above MSL: . ft

Sample type: Normal

Sample matrix: Water

\section{Constituent}

RQ AQ B Result

Unit ssMDL Method

Specified Analyses

Chloride

Cyanide

Hardness as $\mathrm{CACO} 3$

Nitrate as nitrogen

Nitrate-nitrite as nitrogen

Metals (total recoverable)

Aluminum
Antimony
Arsenic
Barium
Beryllium
Cadmium
Calcium
Chromium
Cobalt
Copper
Iron
Lead
Magnesium
Manganese

Sample ID: 114004 
SURVEY ID: BG 00203 (cont.)

Constituent

Metals (total recoverable)

Mercury

Nickel

Potassium

Selenium

Silver

Sodium

Thallium

Tin

Vanadium

Zinc

\section{Radionuclides}

Actinium-228

Americium-241

Antimony-124

Antimony-125

Barium-133

Cerium-144

Cesium-134

Cesium-137

Cobalt-57

Cobalt-58

Cobalt-60

Curium-242

Curium-243/244

Curium-245/246

Europium-152

Europium-154

Europium-155

Gross alpha

Lead-212

Manganese-54

Neptunium-237

Neptunium-239

Nonvolatile beta

Potassium -40

Promethium-144

Promethium-146

Radium-226

Radium-226

Ruthenium-106

Sodium-22

Tin-113

Tritium

Uranium-233/234

Uranium-235

Uranium-238

Yttrium-88

Zinc-65

Zirconium-95
Sample ID: 114004

RQ AQ B Result

Unit ssMDL Method

$\begin{array}{lll}\mu \mathrm{g} / \mathrm{L} & 0.104 & \text { EPA7470 } \\ \mu \mathrm{g} / \mathrm{L} & 2.27 & \text { EPA6010A } \\ \mu \mathrm{g} / \mathrm{L} & 5.87 & \text { EPA6010A } \\ \mu \mathrm{g} / \mathrm{L} & 1.4 & \text { EPA6010A } \\ \mu \mathrm{g} / \mathrm{L} & 0.62 & \text { EPA6010A } \\ \mu \mathrm{g} / \mathrm{L} & 29.1 & \text { EPA6010A } \\ \mu \mathrm{g} / \mathrm{L} & 2.63 & \text { EPA6010A } \\ \mu \mathrm{g} / \mathrm{L} & 2.94 & \text { EPA6010A } \\ \mu \mathrm{g} / \mathrm{L} & 0.427 & \text { EPA6010A } \\ \mu \mathrm{g} / \mathrm{L} & 0.966 & \text { EPA6010A }\end{array}$

pCi/L 2.05E+01 EPIA-013

$\mathrm{PCi} / \mathrm{L}$ 1.33E-01 EPIA-011

$\mathrm{pCi} / \mathrm{L} \quad 5.50 \mathrm{E}+00$ EPIA-013

$\mathrm{pCi} / \mathrm{L} \quad 1.26 \mathrm{E}+01$ EPIA-013

$\mathrm{pCi} / \mathrm{L} \quad 5.11 \mathrm{E}+00$ EPIA-013

$\mathrm{pCi} / \mathrm{L} \quad 2.57 \mathrm{E}+01$ EPIA-013

$\mathrm{pCi} / \mathrm{L} \quad 4.37 \mathrm{E}+00$ EPIA-013

$\mathrm{pCi} / \mathrm{L} \quad 4.94 \mathrm{E}+00$ EPIA-013

$\mathrm{pCi} / \mathrm{L} \quad 3.39 \mathrm{E}+00$ EPIA-013

$\mathrm{pCi} / \mathrm{L} \quad 4.84 \mathrm{E}+00$ EPIA-013

$\mathrm{pCi} / \mathrm{L} \quad 4.60 \mathrm{E}+00$ EPIA-013

$\mathrm{pCi} / \mathrm{L}$ 1.18E-01 EPIA-011

$\mathrm{pCi} / \mathrm{L} \quad 1.47 \mathrm{E}-01 \quad$ EPIA-011

$\mathrm{pCi} / \mathrm{L}$ 4.57E-02 EPIA-011

$\mathrm{pCi} / \mathrm{L} \quad 1.27 \mathrm{E}+01$ EPIA-013

$\mathrm{pCi} / \mathrm{L} 1.46 \mathrm{E}+01$ EPIA-013

$\mathrm{pCi} / \mathrm{L} \quad 1.38 \mathrm{E}+01$ EPIA-013

$\mathrm{pCi} / \mathrm{L} \quad 2.45 \mathrm{E}+00$ EPIA-001

$\mathrm{pCi} / \mathrm{L} \quad 8.35 \mathrm{E}+00$ EPIA-013

$\mathrm{pCi} / \mathrm{L} \quad 4.76 \mathrm{E}+00$ EPIA-013

$\mathrm{pCi} / \mathrm{L} \quad 1.49 \mathrm{E}-01$ EPIA-032

$\mathrm{pCi} / \mathrm{L}$ 2.42E+01 EPIA-013

$\mathrm{pCi} / \mathrm{L} \quad 2.88 \mathrm{E}+00$ EPIA-001

$\mathrm{pCi} / \mathrm{L} \quad 4.34 \mathrm{E}+01$ EPIA-013

$\mathrm{pCi} / \mathrm{L}$ 4.60E+00 EPIA-013

pCi/L 5.71E+00 EPIA-013

$\mathrm{pCi} / \mathrm{L} \quad 4.52 \mathrm{E}-01$ EPIA-008

$\mathrm{pCi} / \mathrm{L}$ 6.13E-01 EPIA-008

$\mathrm{pCi} / \mathrm{L}$ 4.33E+01 EPIA-013

$\mathrm{pCi} / \mathrm{L} \quad 5.22 \mathrm{E}+00$ EPIA-013

pCi/L 6.23E+00 EPIA-013

$\mathrm{pCi} / \mathrm{mL6.40E}-01$ EPA906.0

$\mathrm{pCi} / \mathrm{L} \quad 3.17 \mathrm{E}-01$ EPIA-011

$\mathrm{pCi} / \mathrm{L}$ 2.85E-01 EPIA-011

$\mathrm{pCi} / \mathrm{L}$ 4.66E-01 EPIA-011

$\mathrm{pCi} / \mathrm{L} \quad 6.54 \mathrm{E}+00$ EPIA-013

$\mathrm{pCi} / \mathrm{L} \quad 9.64 \mathrm{E}+00$ EPIA-013

$\mathrm{pCi} / \mathrm{L}$ 8.45E +00 EPIA-013 
Survey location: $59281 \mathrm{E} 67633 \mathrm{~N}$ (SRS coordinates)

Ground elevation above MSL: . ft

Sample type: Normal

Sample matrix: Water

\section{Constituent}

Specified Analyses

Chloride
Cyanide
Hardness as CACO 3
Nitrate as nitrogen
Nitrate-nitrite as nitrogen

Metals (total recoverable)
RQ AQ B Result

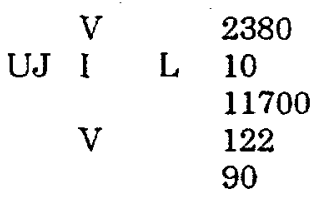

$\begin{array}{llll}\text { J } & \text { I } & \text { L } & 174 \\ \text { U } & & & 10 \\ \text { U } & & & 5 \\ & & & 19.4 \\ \text { U } & & & 5 \\ \text { U } & & & 5 \\ & \text { V } & & 954 \\ U & & & 5 \\ U & & & 5 \\ U & & & 5 \\ & & & 700 \\ U & & & 5 \\ & V & & 445 \\ & & & 97.2 \\ U & & & 0.2 \\ U & & & 5 \\ & & & 146 \\ U & & & 5 \\ U & & & 5 \\ & \text { V } & & 1470 \\ U & & & 10 \\ U & & & 10 \\ U & & & 5 \\ U & \text { V } & & 4.9\end{array}$

Radionuclides

Actinium-228

Antimony-124

Antimony-125

Barium-133

Cerium-144

Cesium-134

Cesium-137

Cobalt-57

Cobalt-58

Cobalt -60

Europium-152

Europium-154

Europium-155

Gross alpha

Lead-212

\begin{tabular}{|c|c|}
\hline UI & $4.72 \mathrm{E}+00$ \\
\hline UI & $-8.55 \mathrm{E}-01$ \\
\hline UI & $1.70 \mathrm{E}+00$ \\
\hline UI & 5.21E-01 \\
\hline UI & $-2.16 \mathrm{E}+00$ \\
\hline UI & $9.79 \mathrm{E}-01$ \\
\hline UI & $-7.11 \mathrm{E}-01$ \\
\hline $\mathrm{UI}$ & $-6.67 \mathrm{E}-01$ \\
\hline UI & $-2.17 \mathrm{E}+00$ \\
\hline UI & $1.54 \mathrm{E}-01$ \\
\hline UI & $-4.96 \mathrm{E}+00$ \\
\hline UI & $6.64 \mathrm{E}+00$ \\
\hline UI & $2.28 \mathrm{E}+00$ \\
\hline & $8.28 \mathrm{E}-01$ \\
\hline 4 & $1.24 \mathrm{E}+01$ \\
\hline
\end{tabular}

Unit ssMDL Method

$\begin{array}{ll}\mu \mathrm{g} / \mathrm{L} & 7 \\ \mu \mathrm{g} / \mathrm{L} & 3.34 \\ \mu \mathrm{g} / \mathrm{L} & 1000 \\ \mu \mathrm{g} / \mathrm{L} & 6 \\ \mu \mathrm{g} / \mathrm{L} & 7\end{array}$

EPA300.0

EPA335.3

EPA130.2

EPA300.0

EPA353.1

$\begin{array}{lll}\mu \mathrm{g} / \mathrm{L} & 37.6 & \text { EPA6010A } \\ \mu \mathrm{g} / \mathrm{L} & 1.64 & \text { EPA6010A } \\ \mu \mathrm{g} / \mathrm{L} & 2.98 & \text { EPA6010A } \\ \mu \mathrm{g} / \mathrm{L} & 0.332 & \text { EPA6010A } \\ \mu \mathrm{g} / \mathrm{L} & 0.223 & \text { EPA6010A } \\ \mu \mathrm{g} / \mathrm{L} & 0.208 & \text { EPA6010A } \\ \mu \mathrm{g} / \mathrm{L} & 15.4 & \text { EPA6010A } \\ \mu \mathrm{g} / \mathrm{L} & 0.729 & \text { EPA6010A } \\ \mu \mathrm{g} / \mathrm{L} & 0.671 & \text { EPA6010A } \\ \mu \mathrm{g} / \mathrm{L} & 1.32 & \text { EPA6010A } \\ \mu \mathrm{g} / \mathrm{L} & 8.63 & \text { EPA6010A } \\ \mu \mathrm{g} / \mathrm{L} & 0.678 & \text { EPA6010A } \\ \mu \mathrm{g} / \mathrm{L} & 3.33 & \text { EPA6010A } \\ \mu \mathrm{g} / \mathrm{L} & 0.903 & \text { EPA6010A } \\ \mu \mathrm{g} / \mathrm{L} & 0.104 & \text { EPA7470 } \\ \mu \mathrm{g} / \mathrm{L} & 2.27 & \text { EPA6010A } \\ \mu \mathrm{g} / \mathrm{L} & 5.87 & \text { EPA6010A } \\ \mu \mathrm{g} / \mathrm{L} & 1.4 & \text { EPA6010A } \\ \mu \mathrm{g} / \mathrm{L} & 0.62 & \text { EPA6010A } \\ \mu \mathrm{g} / \mathrm{L} & 29.1 & \text { EPA6010A } \\ \mu \mathrm{g} / \mathrm{L} & 2.63 & \text { EPA6010A } \\ \mu \mathrm{g} / \mathrm{L} & 2.94 & \text { EPA6010A } \\ \mu \mathrm{g} / \mathrm{L} & 0.427 & \text { EPA6010A } \\ \mu \mathrm{g} / \mathrm{L} & 0.966 & \text { EPA6010A }\end{array}$

$\mathrm{pCi} / \mathrm{L} \quad 1.94 \mathrm{E}+01$ EPIA-013 $\mathrm{pCi} / 2.17 \mathrm{E}+00$ EPIA-013 $\mathrm{pCi} / \mathrm{L} \quad 1.07 \mathrm{E}+01$ EPIA-013 $\mathrm{pCi} / \mathrm{L} \quad 5.37 \mathrm{E}+00$ EPIA-013 $\mathrm{pCi} / \mathrm{L} \quad 2.54 \mathrm{E}+01$ EPIA-013 $\mathrm{pCi} / \mathrm{L} \quad 4.46 \mathrm{E}+00$ EPIA-013 $\mathrm{pCi} / \mathrm{L}$ 4.12E+00 EPIA-013 $\mathrm{pCi} / \mathrm{L} \quad 3.14 \mathrm{E}+00$ EPIA-013 $\mathrm{pCi} / \mathrm{L} \quad 4.57 \mathrm{E}+00$ EPIA-013 $\mathrm{pCi} / \mathrm{L} \quad 4.82 \mathrm{E}+00$ EPIA-013 $\mathrm{pCi} / \mathrm{L} \quad 1.13 \mathrm{E}+01$ EPIA-013 $\mathrm{pCi} / \mathrm{L} \quad 1.48 \mathrm{E}+01$ EPIA-013 $\mathrm{pCi} / \mathrm{L}$ 1.32E+01 EPIA-013 $\mathrm{pCi} / \mathrm{L}$ 4.18E-01 EPIA-001 $\mathrm{pCi} / \mathrm{L} \quad 8.76 \mathrm{E}+00$ EPIA-013 
SURVEY ID: BG 00303 (cont.)

Constituent

Radionuclides

Manganese-54

Neptunium-239

Nonvolatile beta

Potassium -40

Promethium-144

Promethium-146

Ruthenium-106

Sodium-22

Tin-113

Tritium

Yttrium-88

Zinc-65

Zirconium-95
Sample ID: 114005

RQ AQ B Result
$1.17 \mathrm{E}+00$
$-3.17 \mathrm{E}+00$
$1.12 \mathrm{E}+00$
$4.91 \mathrm{E}+01$
$1.39 \mathrm{E}+00$
$1.56 \mathrm{E}+00$
$9.22 \mathrm{E}+00$
$2.38 \mathrm{E}+00$
$3.15 \mathrm{E}+00$
$2.26 \mathrm{E}+00$
$-2.29 \mathrm{E}-01$
$2.60 \mathrm{E}+00$
$1.01 \mathrm{E}+00$

Unit ssMDL Method

$\mathrm{pCi} / \mathrm{L} \quad 4.28 \mathrm{E}+00$ EPIA-013

$\mathrm{PCi} / \mathrm{L} \quad 2.30 \mathrm{E}+01$ EPIA-013

$\mathrm{pCi} / \mathrm{L} \quad 1.13 \mathrm{E}+00$ EPIA-001

$\mathrm{pCi} / \mathrm{L} \quad 6.86 \mathrm{E}+01$ EPIA-013

$\mathrm{pCi} / \mathrm{L} \quad 4.38 \mathrm{E}+00$ EPIA-013

$\mathrm{pCi} / \mathrm{L} \quad 5.17 \mathrm{E}+00$ EPIA-013

pCi/L 4.05E+01 EPIA-013

pCi/ 5.30E+00 EPIA-013

$\mathrm{pCi} / \mathrm{L} 5.40 \mathrm{E}+00$ EPIA-013

$\mathrm{pCi} / \mathrm{mL} 5.74 \mathrm{E}-01 \quad$ EPA906.0

$\mathrm{pCi} / \mathrm{L} \quad 5.25 \mathrm{E}+00$ EPIA-013

$\mathrm{pCi} / \mathrm{L} \quad 8.77 \mathrm{E}+00$ EPIA-013

$\mathrm{pCi} / \mathrm{L} \quad 8.63 \mathrm{E}+00$ EPIA-013

SURVEY ID: BG 00403

Sample ID: 114010

Survey location: $68527 \mathrm{E} 64723 \mathrm{~N}$ (SRS coordinates)

Ground elevation above MSL: . ft

Sample type: Normal

Sample matrix: Water

Constituent

RQ AQ B Result

Unit ssMDL Method

Specified Analyses

Chloride

Cyanide

Hardness as $\mathrm{CACO} 3$

Nitrate as nitrogen

Nitrate-nitrite as nitrogen

Metals (total recoverable)

$\begin{array}{llll}\text { Aluminum } & & \text { V } & 453 \\ \text { Antimony } & \text { U } & & 10 \\ \text { Arsenic } & \text { U } & & 5 \\ \text { Barium } & & & 24 \\ \text { Beryllium } & \text { U } & & 5 \\ \text { Cadmium } & \text { U } & & 5 \\ \text { Calcium } & & & 1020 \\ \text { Chromium } & \text { U } & & 5 \\ \text { Cobalt } & \text { U } & & 5 \\ \text { Copper } & \text { U } & & 5 \\ \text { Iron } & & & 1310 \\ \text { Lead } & \text { U } & \text { V } & 0.734 \\ \text { Magnesium } & & & 458 \\ \text { Manganese } & & \text { V } & 76.8 \\ \text { Mercury } & \text { U } & & 0.2 \\ \text { Nickel } & \text { J } & \text { E } & 3.36 \\ \text { Potassium } & & \text { V } & 273 \\ \text { Selenium } & \text { U } & & 5 \\ \text { Silver } & \text { U } & \text { V } & 3.1 \\ \text { Sodium } & & \text { V } & 1650 \\ \text { Thallium } & \text { U } & & 10\end{array}$

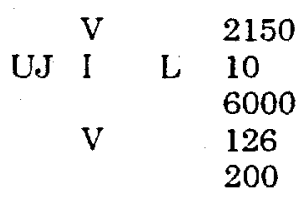

$\mu \mathrm{g} / \mathrm{L} \quad 7$

$\mu \mathrm{g} / \mathrm{L} \quad 3.34$

$\mu \mathrm{g} / \mathrm{L} \quad 1000$

$\mu \mathrm{g} / \mathrm{L} \quad 6$

$\mu \mathrm{g} / \mathrm{L} \quad 7$

EPA300.0

EPA335.3

EPA130.2

EPA 300.0

EPA353.1

$\mu \mathrm{g} / \mathrm{L} \quad 37.6$

$\mu \mathrm{g} / \mathrm{L} \quad 1.64$

EPA6010A

$\mu \mathrm{g} / \mathrm{L} \quad 2.98$

$\mu \mathrm{g} / \mathrm{L} \quad 0.332$

$\mu \mathrm{g} / \mathrm{L} \quad 0.223$

$\mu \mathrm{g} / \mathrm{L} \quad 0.208$

$\mu \mathrm{g} / \mathrm{L} \quad 15.4$

$\mu \mathrm{g} / \mathrm{L} \quad 0.729$

$\mu \mathrm{g} / \mathrm{L} \quad 0.671$

$\mu \mathrm{g} / \mathrm{L} \quad 1.32$

$\mu \mathrm{g} / \mathrm{L} \quad 8.63$

$\mu \mathrm{g} / \mathrm{L} \quad 0.678$

$\mu \mathrm{g} / \mathrm{L} \quad 3.33$

$\mu \mathrm{g} / \mathrm{L} \quad 0.903$

$\mu \mathrm{g} / \mathrm{L} \quad 0.104$

$\mu \mathrm{g} / \mathrm{L} \quad 2.27$

$\mu \mathrm{g} / \mathrm{L} \quad \mathbf{5 . 8 7}$

$\mu \mathrm{g} / \mathrm{L} \quad 1.4$

$\mu \mathrm{g} / \mathrm{L} \quad 0.62$

$\mu \mathrm{g} / \mathrm{L} \quad 29.1$

$\mu \mathrm{g} / \mathrm{L} \quad 2.63$
EPA6010A

EPA6010A

EPA6010A

EPA6010A

EPA6010A

EPA6010A

EPA6010A

EPA6010A

EPA6010A

EPA6010A

EPA6010A

EPA6010A

EPA6010A

EPA7470

EPA6010A

EPA6010A

EPA6010A

EPA6010A
EPA6010A

EPA6010A 
SURVEY ID: BG 00403 (cont.)

Constituent

Metals (total recoverable)

Tin

Vanadium

Zinc
Sample ID: 114010

RQ AQ B Result

Unit ssMDL Method

$\mu \mathrm{g} / \mathrm{L} \quad 2.94$

$\mu \mathrm{g} / \mathrm{L} \quad 0.427$

$\mu \mathrm{g} / \mathrm{L} \quad 0.966$

EPA6010A

EPA6010A

EPA6010A

\section{Radionuclides}

Actinium-228

Antimony-124

Antimony -125

Barium-133

Cerium-144

Cesium-134

Cesium-137

Cobalt-57

Cobalt-58

Cobalt-60

Europium-152

Europium-154

Europium-155

Gross alpha

Lead-212

Manganese-54

Neptunium-239

Nonvolatile beta

Potassium-40

Promethium-144

Promethium-146

Ruthenium-106

Sodium-22

Tin-113

Tritium

Yttrium-88

Zinc-65

Zirconium-95

SURVEY ID: FMC001F03

$\begin{array}{ll}\text { UI } & 5.62 \mathrm{E}+00 \\ \text { UI } & -2.10 \mathrm{E}+00 \\ \text { UI } & -1.32 \mathrm{E}+00 \\ \text { UI } & -5.61 \mathrm{E}+00 \\ \text { UI } & -2.12 \mathrm{E}+00 \\ \text { UI } & -2.02 \mathrm{E}+00 \\ \text { UI } & 2.21 \mathrm{E}+00 \\ \text { UI } & 1.80 \mathrm{E}+00 \\ \text { UI } & -1.53 \mathrm{E}+00 \\ \text { UI } & -3.89 \mathrm{E}-01 \\ \text { UI } & 2.67 \mathrm{E}+00 \\ \text { UI } & 4.23 \mathrm{E}+00 \\ \text { UI } & 1.77 \mathrm{E}-01 \\ & 8.69 \mathrm{E}-01 \\ \text { R } & 2.93 \mathrm{E}+01 \\ \text { UI } & -7.21 \mathrm{E}-01 \\ \text { UI } & -1.89 \mathrm{E}+01 \\ & 1.01 \mathrm{E}+00 \\ & 8.89 \mathrm{E}+01 \\ \text { UI } & 3.40 \mathrm{E}+00 \\ \text { UI } & 1.20 \mathrm{E}+00 \\ \text { UI } & 2.00 \mathrm{E}+01 \\ \text { UI } & 1.96 \mathrm{E}+00 \\ \text { UI } & 2.49 \mathrm{E}-01 \\ & 1.32 \mathrm{E}+00 \\ \text { UI } & 8.35 \mathrm{E}-01 \\ \text { UI } & 2.43 \mathrm{E}+00 \\ \text { UI } & -4.78 \mathrm{E}+00\end{array}$

$\mathrm{pCi} / \mathrm{L} 3.05 \mathrm{E}+01$ EPIA-013

$\mathrm{pCi} / \mathrm{L} \quad 7.68 \mathrm{E}+00$ EPIA-013

$\mathrm{pCi} / \mathrm{L}$ 1.69E+01 EPIA-013

$\mathrm{pCi} / \mathrm{L} \quad 7.20 \mathrm{E}+00$ EPIA-013

pCi/L 3.65E+01 EPIA-013

$\mathrm{pCi} / \mathrm{L} \quad 6.48 \mathrm{E}+00$ EPIA-013

$\mathrm{pCi} / \mathrm{L} \quad 7.34 \mathrm{E}+00$ EPIA-013

pCi/ $4.86 \mathrm{E}+00 \cdot$ EPIA-013

$\mathrm{pCi} / \mathrm{L} \quad 6.84 \mathrm{E}+00$ EPIA-013

$\mathrm{pCi} / \mathrm{L} \quad 7.11 \mathrm{E}+00$ EPIA-013

$\mathrm{PCi} / \mathrm{L}$ 1.83E+01 EPIA-013

$\mathrm{pCi} / \mathrm{L} \quad 1.94 \mathrm{E}+01$ EPIA-013

$\mathrm{pCi} / \mathrm{L}$ 1.99E+01 EPIA-013

$\mathrm{pCi} / \mathrm{L}$ 4.38E-01 EPIA-001

$\mathrm{pCi} / \mathrm{L} \quad 1.31 \mathrm{E}+01$ EPIA-013

$\mathrm{pCi} / \mathrm{L}$ 6.65E+00 EPIA-013

$\mathrm{pCi} / \mathrm{L} \quad 3.53 \mathrm{E}+01$ EPIA-013

$\mathrm{pCi} / \mathrm{L}$ 9.40E-01 EPIA-001

$\mathrm{pCi} / \mathrm{L} \quad 7.36 \mathrm{E}+01$ EPIA-013

$\mathrm{pCi} / \mathrm{L}$ 7.06E+00 EPIA-013

$\mathrm{pCi} / \mathrm{L} \quad 8.83 \mathrm{E}+00$ EPIA-013

$\mathrm{pCi} / 2.46 \mathrm{E}+01$ EPIA-013

$\mathrm{pCi} / \mathrm{L}$ 6.93E+00 EPIA-013

$\mathrm{pCi} / \mathrm{L} \quad 8.32 \mathrm{E}+00$ EPIA-013

$\mathrm{pCi} / \mathrm{mL6.20E-01} \mathrm{EPA906.0}$

$\mathrm{pCi} / \mathrm{L} \quad 8.03 \mathrm{E}+00$ EPIA-013

$\mathrm{pCi} / \mathrm{L} \quad 1.36 \mathrm{E}+01$ EPIA-013

$\mathrm{pCi} / \mathrm{L}$ 1.16E+01 EPIA-013

Sample ID: 114002

Survey location: $57050 \mathrm{E} 70350 \mathrm{~N}$ (SRS coordinates)

Ground elevation above MSL: . $\mathrm{ft}$

Sample type: Normal

Sample matrix: Water

Constituent

Specified Analyses

Chloride

Cyanide

Hardness as $\mathrm{CACO} 3$

Nitrate as nitrogen

Nitrate-nitrite as nitrogen
RQ AQ B Result

Unit ssMDL Method

$\mu \mathrm{g} / \mathrm{L} \quad 35$

$\mu \mathrm{g} / \mathrm{L} \quad 3.34$

$\mu \mathrm{g} / \mathrm{L} \quad 1000$

$\mu \mathrm{g} / \mathrm{L} \quad 6$

$\mu \mathrm{g} / \mathrm{L} \quad 7$
EPA300.0

EPA335.3

EPA130.2

EPA300.0

EPA353.1

Data Summary Report for the Annual Fourmile Branch and

F- and H-Area Seeplines, Appendix IX Metals and Radionuclides, 1998

(WSRC-TR-98-00260) 
SURVEY ID: FMC001F03 (cont.)

Constituent

Metals (total recoverable)

Aluminum

Antimony

Arsenic

Barium

Beryllium

Cadmium

Calcium

Chromium

Cobalt

Copper

Iron

Lead

Magnesium

Manganese

Mercury

Nickel

Potassium

Selenium

Silver

Sodium

Thallium

Tin

Vanadium

Zinc

Radionuclides

Actinium-228

Antimony-124

Antimony-125

Barium-133

Cerium-144

Cesium-134

Cesium-137

Cobalt-57

Cobalt-58

Cobalt-60

Europium-152

Europium-154

Europium-155

Gross alpha

Lead-212

Manganese-54

Neptunium-239

Nonvolatile beta

Potassium-40

Promethium-144

Promethium-146

Ruthenium-106

Sodium-22

Tin-113

Tritium

Yttrium-88
Sample ID: 114002

RQ AQ B Result

Unit ssMDL Method

$\begin{array}{lll}\mu \mathrm{g} / \mathrm{L} & 37.6 & \text { EPA6010A } \\ \mu \mathrm{g} / \mathrm{L} & 1.64 & \text { EPA6010A } \\ \mu \mathrm{g} / \mathrm{L} & 2.98 & \text { EPA6010A } \\ \mu \mathrm{g} / \mathrm{L} & 0.332 & \text { EPA6010A } \\ \mu \mathrm{g} / \mathrm{L} & 0.223 & \text { EPA6010A } \\ \mu \mathrm{g} / \mathrm{L} & 0.208 & \text { EPA6010A } \\ \mu \mathrm{g} / \mathrm{L} & 15.4 & \text { EPA6010A } \\ & & \\ \mu \mathrm{g} / \mathrm{L} & 0.729 & \text { EPA6010A } \\ \mu \mathrm{g} / \mathrm{L} & 0.671 & \text { EPA6010A } \\ \mu \mathrm{g} / \mathrm{L} & 1.32 & \text { EPA6010A } \\ \mu \mathrm{g} / \mathrm{L} & 8.63 & \text { EPA6010A } \\ \mu \mathrm{g} / \mathrm{L} & 0.678 & \text { EPA6010A } \\ \mu \mathrm{g} / \mathrm{L} & 3.33 & \text { EPA6010A } \\ \mu \mathrm{g} / \mathrm{L} & 0.903 & \text { EPA6010A } \\ \mu \mathrm{g} / \mathrm{L} & 0.104 & \text { EPA7470 } \\ \mu \mathrm{g} / \mathrm{L} & 2.27 & \text { EPA6010A } \\ \mu \mathrm{g} / \mathrm{L} & 5.87 & \text { EPA6010A } \\ \mu \mathrm{g} / \mathrm{L} & 1.4 & \text { EPA6010A } \\ \mu \mathrm{g} / \mathrm{L} & 0.62 & \text { EPA6010A } \\ \mu \mathrm{g} / \mathrm{L} & 29.1 & \text { EPA6010A } \\ \mu \mathrm{g} / \mathrm{L} & 2.63 & \text { EPA6010A } \\ \mu \mathrm{g} / \mathrm{L} & 2.94 & \text { EPA6010A } \\ \mu \mathrm{g} / \mathrm{L} & 0.427 & \text { EPA6010A } \\ \mu \mathrm{g} / \mathrm{L} & 0.966 & \text { EPA6010A }\end{array}$

$\mathrm{pCi} / \mathrm{L} \quad 1.80 \mathrm{E}+01$ EPIA-013

$\mathrm{pCi} / \mathrm{L}$ 4.70E+00 EPIA-013

$\mathrm{pCi} / \mathrm{L} \quad 1.10 \mathrm{E}+01$ EPIA-013

$\mathrm{pCi} / \mathrm{L}$ 5.51E+00 EPIA-013

$\mathrm{pCi} / \mathrm{L} \quad 2.72 \mathrm{E}+01$ EPIA-013

$\mathrm{pCi} / \mathrm{L}, 3.63 \mathrm{E}+00$ EPIA-013

$\mathrm{pCi} / \mathrm{L} \quad 4.35 \mathrm{E}+00$ EPIA-013

$\mathrm{PCi} / \mathrm{L} \quad 3.53 \mathrm{E}+00$ EPIA-013

$\mathrm{pCi} / \mathrm{L} \quad 4.34 \mathrm{E}+00$ EPIA-013

$\mathrm{pCi} / \mathrm{L} \quad 4.36 \mathrm{E}+00$ EPIA-013

$\mathrm{pCi} / \mathrm{L} \quad 1.22 \mathrm{E}+01$ EPIA-013

$\mathrm{pCi} / \mathrm{L} \quad 1.37 \mathrm{E}+01$ EPIA-013

$\mathrm{pCi} / \mathrm{L} \quad 1.48 \mathrm{E}+01$ EPIA-013

$\mathrm{pCi} / \mathrm{L}$ 5.09E-01 EPIA-001

pCi/L 8.73E+00 EPIA-013

$\mathrm{pCi} / \mathrm{L} \quad 3.92 \mathrm{E}+00$ EPIA-013

$\mathrm{pCi} / \mathrm{L} \quad 2.50 \mathrm{E}+01$ EPIA-013

$\mathrm{pCi} / \mathrm{L}$ 1.20E+00 EPIA-001

pCi/L 5.06E+01 EPIA-013

$\mathrm{pCi} / \mathrm{L}$ 4.29E+00 EPIA-013

$\mathrm{pCi} / \mathrm{L} \quad 5.49 \mathrm{E}+00$ EPIA-013

$\mathrm{pCi} / \mathrm{L} \quad 4.05 \mathrm{E}+01$ EPIA-013

$\mathrm{pCi} / \mathrm{L} \quad 4.91 \mathrm{E}+00$ EPIA-013

$\mathrm{pCi} / \mathrm{L} \quad 5.28 \mathrm{E}+00$ EPIA-013

pCi/mL5.72E-01 EPA906.0

pCi/ 4.79E+00 EPIA-013 
SURVEY ID: FMC001F03 (cont.)

Constituent

Radionuclides

Zinc-65

Zirconium-95

UI

UI

$-2.08 \mathrm{E}+00$

$-3.84 \mathrm{E}-01$
Unit ssMDL Method

$\mathrm{pCi} / \mathrm{L} \quad 8.98 \mathrm{E}+00$ EPIA-013

$\mathrm{pCi} / \mathrm{L} \quad 8.38 \mathrm{E}+00$ EPIA-013
SURVEY ID: FMCOOHHO3

Survey location: $5300 \mathrm{E} 72600 \mathrm{~N}$ (SRS coordinates)

Ground elevation above MSL: . ft

Sample type: Normal

\section{Constituent}

Specified Analyses

Chloride

Chloride

Cyanide

Hardness as $\mathrm{CACO} 3$

Nitrate as nitrogen

Nitrate as nitrogen

Nitrate-nitrite as nitrogen

Metals (total recoverable)

\section{Aluminum \\ Antimony \\ Arsenic \\ Barium \\ Beryllium \\ Cadmium \\ Calcium \\ Chromium \\ Cobalt \\ Copper \\ Iron \\ Lead \\ Magnesium \\ Manganese \\ Mercury \\ Nickel \\ Potassium \\ Selenium \\ Silver \\ Sodium \\ Thallium \\ Tin \\ Vanadium}

Zinc

Radionuclides

Actinium-228

Antimony-124
Sample ID: 114000

Sample matrix: Water
RQ AQ B Result Unit ssMDL Method

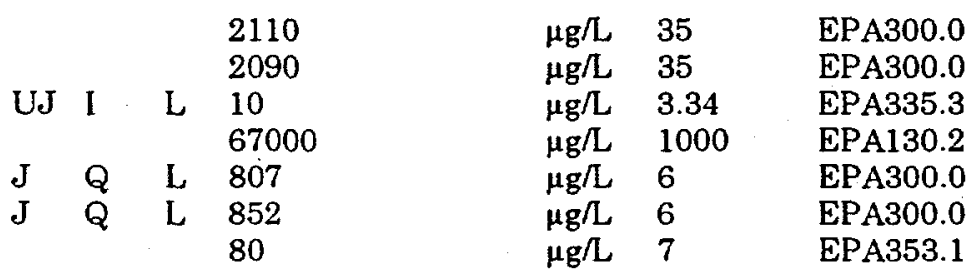

$\begin{array}{lll}\mu \mathrm{g} / \mathrm{L} & 37.6 & \text { EPA6010A } \\ \mu \mathrm{g} / \mathrm{L} & 1.64 & \text { EPA6010A } \\ \mu \mathrm{g} / \mathrm{L} & 2.98 & \text { EPA6010A } \\ \mu \mathrm{g} / \mathrm{L} & 0.332 & \text { EPA6010A } \\ \mu \mathrm{g} / \mathrm{L} & 0.223 & \text { EPA6010A } \\ \mu \mathrm{g} / \mathrm{L} & 0.208 & \text { EPA6010A } \\ \mu \mathrm{g} / \mathrm{L} & 15.4 & \text { EPA6010A } \\ \mu \mathrm{g} / \mathrm{L} & 0.729 & \text { EPA6010A } \\ \mu \mathrm{g} / \mathrm{L} & 0.671 & \text { EPA6010A } \\ \mu \mathrm{g} / \mathrm{L} & 1.32 & \text { EPA6010A } \\ \mu \mathrm{g} / \mathrm{L} & 8.63 & \text { EPA6010A } \\ \mu \mathrm{g} / \mathrm{L} & 0.678 & \text { EPA6010A } \\ \mu \mathrm{g} / \mathrm{L} & 3.33 & \text { EPA6010A } \\ \mu \mathrm{g} / \mathrm{L} & 0.903 & \text { EPA6010A } \\ \mu \mathrm{g} / \mathrm{L} & 0.104 & \text { EPA7470 } \\ \mu \mathrm{g} / \mathrm{L} & 2.27 & \text { EPA6010A } \\ \mu \mathrm{g} / \mathrm{L} & 5.87 & \text { EPA6010A } \\ \mu \mathrm{g} / \mathrm{L} & 1.4 & \text { EPA6010A } \\ \mu \mathrm{g} / \mathrm{L} & 0.62 & \text { EPA6010A } \\ \mu \mathrm{g} / \mathrm{L} & 29.1 & \text { EPA6010A } \\ \mu \mathrm{g} / \mathrm{L} & 2.63 & \text { EPA6010A } \\ \mu \mathrm{g} / \mathrm{L} & 2.94 & \text { EPA6010A } \\ \mu \mathrm{g} / \mathrm{L} & 0.427 & \text { EPA6010A } \\ \mu \mathrm{g} / \mathrm{L} & 0.966 & \text { EPA6010A } \\ & & \end{array}$

$\mathrm{pCi} / \mathrm{L} \quad 2.04 \mathrm{E}+01$ EPIA-013

$\mathrm{PCi} / \mathrm{L} \quad 5.18 \mathrm{E}+00$ EPIA-013 
SURVEY ID: FMC001H03 (cont.)

Constituent

Radionuclides

Antimony-125

Barium-133

Cerium-144

Cesium-134

Cesium-137

Cobalt-57

Cobalt-58

Cobalt -60

Europium-152

Europium-154

Europium-155

Gross alpha

Lead-212

Manganese-54

Neptunium-239

Nonvolatile beta

Potassium-40

Promethium-144

Promethium-146

Ruthenium-106

Sodium-22

Tin-113

Tritium

Yttrium-88

Zinc-65

Zirconium-95
Sample ID: 114000

RQ AQ B Result

1.74E-01

$1.11 \mathrm{E}+00$

$-1.27 \mathrm{E}+01$

$-1.92 \mathrm{E}+00$

$3.88 \mathrm{E}+00$

4.88E-02

$-2.11 \mathrm{E}-01$

$-4.68 \mathrm{E}-01$

6.04E-01

$1.19 \mathrm{E}+00$

$5.95 \mathrm{E}+00$

$1.19 \mathrm{E}+00$

$7.77 \mathrm{E}+00$

$-7.88 \mathrm{E}-01$

$-1.00 \mathrm{E}+00$

$3.58 \mathrm{E}+00$

$6.80 \mathrm{E}+01$

$-1.17 \mathrm{E}-01$

$-1.82 \mathrm{E}+00$

$-7.76 \mathrm{E}+00$

4.53E-01

$-3.79 \mathrm{E}-01$

$6.66 \mathrm{E}+00$

$7.94 \mathrm{E}-01$

$3.80 \mathrm{E}+00$

$-1.34 \mathrm{E}+00$
Unit ssMDL Method

$\mathrm{pCi} / \mathrm{L} \quad 1.20 \mathrm{E}+01$ EPIA-013

$\mathrm{pCi} / \mathrm{L} \quad 5.69 \mathrm{E}+00$ EPIA-013

$\mathrm{pCi} / \mathrm{L} \quad 2.64 \mathrm{E}+01$ EPIA-013

$\mathrm{pCi} / \mathrm{L} \quad 4.18 \mathrm{E}+00$ EPIA-013

$\mathrm{pCi} / \mathrm{L} \quad 5.51 \mathrm{E}+00$ EPIA-013

$\mathrm{pCi} / \mathrm{L} \quad 3.46 \mathrm{E}+00$ EPIA-013

$\mathrm{pCi} / \mathrm{L} \quad 4.72 \mathrm{E}+00$ EPIA-013

$\mathrm{pCi} / \mathrm{L} \quad 5.37 \mathrm{E}+00$ EPIA-013

$\mathrm{pCi} / \mathrm{L} \quad 1.28 \mathrm{E}+01$ EPIA-013

$\mathrm{pCi} / \mathrm{L} \quad 1.56 \mathrm{E}+01$ EPIA-013

$\mathrm{pCi} / 2$ 1.53E+01 EPIA-013

$\mathrm{pCi} / \mathrm{L} \quad 4.59 \mathrm{E}-01$ EPIA-001

$\mathrm{pCi} / \mathrm{L}$ 8.77E+00 EPIA-013

$\mathrm{pCi} / \mathrm{L}$ 4.64E+00 EPIA-013

$\mathrm{pCi} / \mathrm{L}$ 2.56E+01 EPIA-013

$\mathrm{pCi} / \mathrm{L} \quad 1.06 \mathrm{E}+00$ EPIA-001

$\mathrm{pCi} / \mathrm{L} \quad 7.51 \mathrm{E}+01$ EPIA-013

$\mathrm{pCi} / \mathrm{L} \quad 4.51 \mathrm{E}+00$ EPIA-013

$\mathrm{pCi} / \mathrm{L}$ 5.72E+00 EPIA-013

$\mathrm{pCi} / \mathrm{L} \quad 4.04 \mathrm{E}+01$ EPIA-013

$\mathrm{pCi} / \mathrm{L} \quad 5.60 \mathrm{E}+00$ EPIA-013

$\mathrm{pCi} / \mathrm{L} \quad 6.35 \mathrm{E}+00$ EPIA-013

$\mathrm{pCi} / \mathrm{mL} 5.72 \mathrm{E}-01 \quad \mathrm{EPA} 906.0$

$\mathrm{pCi} / \mathrm{L} \quad 5.76 \mathrm{E}+00$ EPIA-013

$\mathrm{pCi} / \mathrm{L} \quad 1.11 \mathrm{E}+01$ EPIA-013

$\mathrm{pCi} / \mathrm{L} 9.23 \mathrm{E}+00$ EPIA-013
SURVEY ID: FMC002H03

Survey location: $53000 \mathrm{E} 72600 \mathrm{~N}$ (SRS coordinates)

Ground elevation above MSL: . $\mathrm{ft}$

Sample type: Normal

Constituent

Specified Analyses

Chloride

Cyanide

Hardness as $\mathrm{CACO} 3$

Nitrate as nitrogen

Nitrate-nitrite as nitrogen

Metals (total recoverable)

Aluminum

Antimony

Arsenic

Barium

Beryllium

Cadmium

Calcium

Chromium
Sample matrix: Water

RQ AQ B Result

Unit ssMDL Method

$\mu g / L \quad 35$

$\mu \mathrm{g} / \mathrm{L} \quad 3.34$

$\mu \mathrm{g} / \mathrm{L} \quad 1000$

$\mu \mathrm{g} / \mathrm{L} \quad 6$

$\mu \mathrm{g} / \mathrm{L} \quad 7$

EPA300.0

EPA335.3

EPA130.2

EPA300.0

EPA353.1

$\mu \mathrm{g} / \mathrm{L} \quad 37.6$

EPA6010A

$\mu \mathrm{g} / \mathrm{L} \quad 1.64 \quad$ EPA6010A

$\mu \mathrm{g} / \mathrm{L} \quad 2.98 \quad$ EPA6010A

$\mu \mathrm{g} / \quad 0.332 \quad$ EPA6010A

$\mu \mathrm{g} / \mathrm{L} \quad 0.223 \quad$ EPA6010A

$\mu \mathrm{g} / \mathrm{L} \quad 0.208 \quad$ EPA6010A

$\mu \mathrm{g} / \mathrm{L} \quad 15.4 \quad$ EPA6010A

$\mu \mathrm{g} / \mathrm{L} \quad 0.729 \quad$ EPA6010A

Data Summary Report for the Annual Fourmile Branch and F- and H-Area Seeplines, Appendix IX Metals and Radionuclides, 1998 (WSRC-TR-98-00260) 
SURVEY ID: FMC002H03 (cont.)

Constituent

Metals (total recoverable)

Cobalt
Copper
Iron
Lead
Magnesium
Manganese
Mercury
Nickel
Potassium
Selenium
Silver
Sodium
Thallium
Tin
Vanadium
Zinc

Radionuclides

Actinium-228

Antimony-124

Antimony-125

Barium-133

Cerium-144

Cesium-134

Cesium-137

Cobalt-57

Cobalt-58

Cobalt -60

Europium-152

Europium-154

Europium-155

Gross alpha

Lead-212

Manganese-54

Neptunium-239

Nonvolatile beta

Potassium -40

Promethium-144

Promethium-146

Ruthenium-106

Sodium-22

Tin-113

Tritium

Yttrium-88

Zinc-65

Zirconium-95
Sample ID: 114001

RQ AQ B Result

Unit ssMDL Method

$\begin{array}{lll}\mu \mathrm{g} / \mathrm{L} & 0.671 & \text { EPA6010A } \\ \mu \mathrm{g} / \mathrm{L} & 1.32 & \text { EPA6010A } \\ \mu \mathrm{g} / \mathrm{L} & 8.63 & \text { EPA6010A } \\ \mu \mathrm{g} / \mathrm{L} & 0.678 & \text { EPA6010A } \\ \mu \mathrm{g} / \mathrm{L} & 3.33 & \text { EPA6010A } \\ \mu \mathrm{g} / \mathrm{L} & 0.903 & \text { EPA6010A } \\ \mu \mathrm{g} / \mathrm{L} & 0.104 & \text { EPA7470 } \\ \mu \mathrm{g} / \mathrm{L} & 2.27 & \text { EPA6010A } \\ \mu \mathrm{g} / \mathrm{L} & 5.87 & \text { EPA6010A } \\ \mu \mathrm{g} / \mathrm{L} & 1.4 & \text { EPA6010A } \\ \mu \mathrm{g} / \mathrm{L} & 0.62 & \text { EPA6010A } \\ \mu \mathrm{g} / \mathrm{L} & 29.1 & \text { EPA6010A } \\ \mu \mathrm{g} / \mathrm{L} & 2.63 & \text { EPA6010A } \\ \mu \mathrm{g} / \mathrm{L} & 2.94 & \text { EPA6010A } \\ \mu \mathrm{g} / \mathrm{L} & 0.427 & \text { EPA6010A } \\ \mu \mathrm{g} / \mathrm{L} & 0.966 & \text { EPA6010A }\end{array}$

$\mathrm{pCi} / \mathrm{L} \quad 2.57 \mathrm{E}+01$ EPIA-013

$\mathrm{pCi} / \mathrm{L} \quad 6.11 \mathrm{E}+00$ EPIA-013

$\mathrm{pCi} / \mathrm{L}$ 1.42E+01 EPIA-013

$\mathrm{pCi} / \mathrm{L} 6.15 \mathrm{E}+00$ EPIA-013

$\mathrm{pCi} / \mathrm{L} 2.88 \mathrm{E}+01$ EPIA-013

$\mathrm{pCi} / \mathrm{L} \quad 5.00 \mathrm{E}+00$ EPIA-013

$\mathrm{pCi} / \mathrm{L} \quad 5.49 \mathrm{E}+00$ EPIA-013

$\mathrm{pCi} / \mathrm{L} \quad 3.54 \mathrm{E}+00$ EPIA-013

$\mathrm{pCi} / \mathrm{L} \quad 5.41 \mathrm{E}+00$ EPIA-013

$\mathrm{pCi} / \mathrm{L} \quad 6.95 \mathrm{E}+00$ EPIA-013

$\mathrm{pCi} / \mathrm{L}$ 1.33E+01 EPIA-013

$\mathrm{pCi} / \mathrm{L} \quad 1.58 \mathrm{E}+01$ EPIA-013

$\mathrm{pCi} / \mathrm{L} \quad 1.58 \mathrm{E}+01$ EPIA-013

$\mathrm{pCi} / \mathrm{L}$ 8.14E-01 EPIA-001

$\mathrm{pCi} / \mathrm{L}$ 8.14E+00 EPIA-013

$\mathrm{pCi} / \mathrm{L}$ 5.25E+00 EPIA-013

$\mathrm{pCi} / \mathrm{L} \quad 2.68 \mathrm{E}+01$ EPIA-013

$\mathrm{pCi} / \mathrm{L} \quad 1.40 \mathrm{E}+00$ EPIA-001

$\mathrm{pCi} / \mathrm{L} \quad 4.61 \mathrm{E}+01$ EPIA-013

$\mathrm{pCi} / \mathrm{L} \quad 5.39 \mathrm{E}+00$ EPIA-013

$\mathrm{pCi} / \mathrm{L} \quad 6.64 \mathrm{E}+00$ EPIA-013

$\mathrm{pCi} / \mathrm{L} \quad 5.05 \mathrm{E}+01$ EPIA-013

$\mathrm{pCi} / \mathrm{L} 5.65 \mathrm{E}+00$ EPIA-013

$\mathrm{pCi} / \mathrm{L}$ 6.58E+00 EPIA-013

pCi/mL5.67E-01 EPA906.0

$\mathrm{pCi} / \mathrm{L} \quad 7.36 \mathrm{E}+00$ EPIA-013

$\mathrm{pCi} / \mathrm{L} \quad 1.31 \mathrm{E}+01$ EPIA-013

$\mathrm{pCi} / \mathrm{L} \quad 1.00 \mathrm{E}+01$ EPIA-013 
SURVEY ID: FSP 01203

Sample ID: 114019

Survey location: 49644E 73602N (SRS coordinates)

Ground elevation above MSL: . ft

Sample type: Normal

Sample matrix: Water

Constituent

Specified Analyses

Chloride

Cyanide

Hardness as $\mathrm{CACO} 3$

Nitrate as nitrogen

Nitrate-nitrite as nitrogen

Metals (total recoverable)

Aluminum
Antimony
Arsenic
Barium
Beryllium
Cadmium
Calcium
Chromium
Cobalt
Copper
Iron
Lead
Magnesium
Manganese
Mercury
Nickel
Potassium
Selenium
Silver
Sodium
Thallium
Tin
Vanadium
Zinc

Radionuclides
Actinium-228
Antimony-124
Antimony-125
Barium-133
Cerium-144
Cesium-134
Cesium-137
Cobalt-57
Cobalt-58
Cobalt-60
Europium-152
Europium-154
Europium-155
Gross alpha
Lead-212

RQ AQ B Result

$\begin{array}{lll} & \mathrm{V} & 2380 \\ \mathrm{U} & & 10 \\ & 11500 \\ \mathrm{~V} & 237 \\ \mathrm{~V} & 11400\end{array}$

$\begin{array}{lll} & & 672 \\ \mathrm{U} & & 10 \\ \mathrm{U} & & 5 \\ & & 86.6 \\ \mathrm{U} & & 5 \\ \mathrm{U} & & 5 \\ & \mathrm{~V} & 1440 \\ \mathrm{U} & & 5 \\ \mathrm{~J} & \mathrm{E} & 2.62 \\ \mathrm{U} & & 5 \\ & \mathrm{~V} & 8430 \\ \mathrm{U} & & 5 \\ & \mathrm{~V} & 1090 \\ \mathrm{U} & & 1020 \\ \mathrm{U} & & 0.2 \\ & & 5 \\ \mathrm{U} & & 880 \\ \mathrm{U} & & 5 \\ & & 5 \\ \mathrm{U} & & 1480 \\ \mathrm{U} & & 10 \\ \mathrm{~J} & \mathrm{E} & 10 \\ & & 1.27 \\ & & 35.7\end{array}$

$\begin{array}{ll}\text { UI } & 5.14 \mathrm{E}+00 \\ \text { UI } & -6.74 \mathrm{E}-01 \\ \text { UI } & -2.14 \mathrm{E}+00 \\ \text { UI } & -7.72 \mathrm{E}-01 \\ \text { UI } & 3.02 \mathrm{E}+00 \\ \text { UI } & 5.71 \mathrm{E}-01 \\ \text { UI } & 2.35 \mathrm{E}-01 \\ \text { UI } & 1.12 \mathrm{E}+00 \\ \text { UI } & -2.04 \mathrm{E}-01 \\ \text { UI } & 8.02 \mathrm{E}-02 \\ \text { UI } & -1.80 \mathrm{E}+00 \\ \text { UI } & -9.53 \mathrm{E}-01 \\ \text { UI } & -1.57 \mathrm{E}+00 \\ & 3.39 \mathrm{E}+00 \\ \text { UI } & 4.27 \mathrm{E}+00\end{array}$

Unit ssMDL Method

$\begin{array}{lll}\mu \mathrm{g} / \mathrm{L} & 7 & \text { EPA300.0 } \\ \mu \mathrm{g} / \mathrm{L} & 3.34 & \text { EPA335.3 } \\ \mu \mathrm{g} / \mathrm{L} & 1000 & \text { EPA130.2 } \\ \mu \mathrm{g} / \mathrm{L} & 6 & \text { EPA300.0 } \\ \mu \mathrm{g} / \mathrm{L} & 35 & \text { EPA353.1 }\end{array}$

$\begin{array}{lll}\mu \mathrm{g} / \mathrm{L} & 37.6 & \text { EPA6010A } \\ \mu \mathrm{g} / \mathrm{L} & 1.64 & \text { EPA6010A } \\ \mu \mathrm{g} / \mathrm{L} & 2.98 & \text { EPA6010A } \\ \mu \mathrm{g} / \mathrm{L} & 0.332 & \text { EPA6010A } \\ \mu \mathrm{g} / \mathrm{L} & 0.223 & \text { EPA6010A } \\ \mu \mathrm{g} / \mathrm{L} & 0.208 & \text { EPA6010A } \\ \mu \mathrm{g} / \mathrm{L} & 15.4 & \text { EPA6010A } \\ \mu \mathrm{g} / \mathrm{L} & 0.729 & \text { EPA6010A } \\ \mu \mathrm{g} / \mathrm{L} & 0.671 & \text { EPA6010A } \\ \mu \mathrm{g} / \mathrm{L} & 1.32 & \text { EPA6010A } \\ \mu \mathrm{g} / \mathrm{L} & 8.63 & \text { EPA6010A } \\ \mu \mathrm{g} / \mathrm{L} & 0.678 & \text { EPA6010A } \\ \mu \mathrm{g} / \mathrm{L} & 3.33 & \text { EPA6010A } \\ \mu \mathrm{g} / \mathrm{L} & 0.903 & \text { EPA6010A } \\ \mu \mathrm{g} / \mathrm{L} & 0.104 & \text { EPA7470 } \\ \mu \mathrm{g} / \mathrm{L} & 2.27 & \text { EPA6010A } \\ \mu \mathrm{g} / \mathrm{L} & 5.87 & \text { EPA6010A } \\ \mu \mathrm{g} / \mathrm{L} & 1.4 & \text { EPA6010A } \\ \mu \mathrm{g} / \mathrm{L} & 0.62 & \text { EPA6010A } \\ \mu \mathrm{g} / \mathrm{L} & 29.1 & \text { EPA6010A } \\ \mu \mathrm{g} / \mathrm{L} & 2.63 & \text { EPA6010A } \\ \mu \mathrm{g} / \mathrm{L} & 2.94 & \text { EPA6010A } \\ \mu \mathrm{g} / \mathrm{L} & 0.427 & \text { EPA6010A } \\ \mu \mathrm{g} / \mathrm{L} & 0.966 & \text { EPA6010A }\end{array}$

pCi/ 1.49E+01 EPIA-013

$\mathrm{pCi} / \mathrm{L} \quad 3.68 \mathrm{E}+00$ EPIA-013

$\mathrm{pCi} / \mathrm{L} \quad 8.22 \mathrm{E}+00$ EPIA-013

$\mathrm{pCi} / \mathrm{L} \quad 3.75 \mathrm{E}+00$ EPIA-013

$\mathrm{pCi} / \mathrm{L} 2.08 \mathrm{E}+01$ EPIA-013

$\mathrm{pCi} / \mathrm{L} \quad 3.36 \mathrm{E}+00$ EPIA-013

$\mathrm{pCi} / \mathrm{L} \quad 3.43 \mathrm{E}+00$ EPIA-013

$\mathrm{pCi} / \mathrm{L} 2.69 \mathrm{E}+00$ EPIA-013

$\mathrm{pCi} / \mathrm{L} \quad 3.12 \mathrm{E}+00$ EPIA-013

pCi/ 3.73E +00 EPIA-013

pCi/L 8.19E+00 EPIA-013

$\mathrm{pCi} / \mathrm{L} \quad 9.65 \mathrm{E}+00$ EPIA-013

$\mathrm{pCi} / 2 \quad 1.17 \mathrm{E}+01$ EPIA-013

$\mathrm{pCi} / \mathrm{L}$ 3.24E-01 EPIA-001

$\mathrm{pCi} / \mathrm{L} \quad 6.29 \mathrm{E}+00$ EPIA-013

Data Summary Report for the Annual Fourmile Branch and

F- and H-Area Seeplines, Appendix IX Metals and Radionuclides, 1998

(WSRC-TR-98-00260) 
SURVEY ID: FSP 01203 (cont.)

Constituent

Radionuclides

Manganese-54
Neptunium-239
Nonvolatile beta
Potassium-40
Promethium-144
Promethium-146
Ruthenium-106
Sodium-22
Tin-113
Tritium
Yttrium-88
Zinc-65
Zirconium-95

SURVEY ID: FSP 03203
Sample ID: 114019

RQ AQ B Result

Unit ssMDL Method
$\mathrm{pCi} / \mathrm{L} \quad 3.26 \mathrm{E}+00$ EPIA-013 $\mathrm{pCi} / \mathrm{L} \quad 1.95 \mathrm{E}+01$ EPIA-013 $\mathrm{pCi} / \mathrm{L} \quad 2.03 \mathrm{E}+00$ EPIA-001 $\mathrm{pCi} / \mathrm{L} 2.68 \mathrm{E}+01$ EPIA-013 $\mathrm{pCi} / \mathrm{L} \quad 2.85 \mathrm{E}+00$ EPIA-013 $\mathrm{pCi} / \mathrm{L} \quad 4.24 \mathrm{E}+00$ EPIA-013 $\mathrm{pCi} / \mathrm{L} \quad 3.33 \mathrm{E}+01$ EPIA-013 $\mathrm{pCi} / \mathrm{L} \quad 3.47 \mathrm{E}+00$ EPIA-013 $\mathrm{pCi} / \mathrm{L}$ 4.11E+00 EPIA-013 $\mathrm{pCi} / \mathrm{mL6.00E-01} \mathrm{EPA906.0}$ $\mathrm{pCi} / \mathrm{L} \quad 3.87 \mathrm{E}+00$ EPIA-013 $\mathrm{pCi} / \mathrm{L} \quad 6.93 \mathrm{E}+00$ EPIA-013 $\mathrm{pCi} / \mathrm{L} \quad 5.87 \mathrm{E}+00$ EPIA-013

Survey location: $50258 \mathrm{E} 73367 \mathrm{~N}$ (SRS coordinates)

Ground elevation above MSL: . $\mathrm{ft}$

Sample type: Normal

Sample matrix: Water

\section{Constituent}

RQ AQ B Result

Unit ssMDL Method

Specified Analyses

Chloride

Cyanide

Hardness as $\mathrm{CACO} 3$

Hardness as CACO 3

Nitrate as nitrogen

Nitrate-nitrite as nitrogen

Metals (lotal recoverable)
Sample ID: 114021 
SURVEY ID: FSP 03203 (cont.)

Constituent

Metals (total recoverable)

Thallium

Tin

Vanadium

Zinc

Radionuclides

Actinium-228

Actinium-228

Americium-241

Americium-241

Antimony-124

Antimony-124

Antimony-125

Antimony-125

Barium-133

Barium-133

Cerium-144

Cerium-144

Cesium-134

Cesium-134

Cesium-137

Cesium-137

Cobalt -57

Cobalt -57

Cobalt-58

Cobalt-58

Cobalt-60

Cobalt -60

Curium-242

Curium-242

Curium-243/244

Curium-243/244

Curium-245/246

Curium-245/246

Europium-152

Europium-152

Europium-154

Europium-154

Europium-155

Europium-155

Gross alpha

Iodine-129

Lead-212

Lead-212

Manganese-54

Manganese-54

Neptunium-237

Neptunium-239

Neptunium-239

Nickel-63

Nonvolatile beta

Potassium-40

Potassium -40
Sample ID: 114021
Unit ssMDL Method

$\mu \mathrm{g} / \mathrm{L} \quad 2.63 \quad$ EPA6010A

$\mu \mathrm{g} / \mathrm{L} \quad 2.94 \quad$ EPA6010A

$\mu \mathrm{g} / \quad 0.427 \quad$ EPA6010A

$\mu \mathrm{g} / \mathrm{L} \quad 0.966 \quad$ EPA6010A
32.3

$7.86 \mathrm{E}+00$

$2.66 \mathrm{E}+01$

6.55E-02

1.01E-01

$-9.26 \mathrm{E}-01$

$1.14 \mathrm{E}+00$

$2.48 \mathrm{E}+00$

5.64E-01

$1.69 \mathrm{E}+00$

$1.71 \mathrm{E}+00$

$-1.74 \mathrm{E}+00$

$-8.00 \mathrm{E}-01$

$-1.30 E+00$

2.82E-01

7.66E-01

$1.67 \mathrm{E}+00$

4.99E-01

$-7.19 \mathrm{E}-01$

$1.10 \mathrm{E}-01$

2.83E-01

$-2.12 \mathrm{E}-02$

1.13E-01

$-1.06 \mathrm{E}-02$

$-3.31 \mathrm{E}-02$

1.15E-01

8.85E-02

$0.00 \mathrm{E}+00$

3.18E-02

2.12E-01

$-7.64 \mathrm{E}-02$

7.38E-02

$3.55 \mathrm{E}+00$

2.91E-01

$2.19 \mathrm{E}+00$

$5.11 \mathrm{E}+00$

$1.58 \mathrm{E}+00$

$1.13 \mathrm{E}+00$

$3.50 \mathrm{E}+00$

$-1.50 \mathrm{E}+00$

$-5.49 \mathrm{E}-01$

3.27E-02

$2.52 \mathrm{E}+00$

$4.00 \mathrm{E}+00$

$-1.23 \mathrm{E}+02$

$7.30 \mathrm{E}+01$

$3.02 \mathrm{E}+01$

$3.16 \mathrm{E}+01$
pCi/L 1.61E+01 EPIA-013

$\mathrm{pCi} / \mathrm{L} \quad 1.59 \mathrm{E}+01$ EPIA-013

$\mathrm{pCi} / \mathrm{L} \quad 1.61 \mathrm{E}-01$ EPIA-011

$\mathrm{pCi} / \mathrm{L}$ 1.68E-01 EPIA-011

$\mathrm{pCi} / \mathrm{L}$ 3.83E+00 EPIA-013

$\mathrm{pCi} / \mathrm{L} \quad 3.97 \mathrm{E}+00$ EPIA-013

$\mathrm{pCi} / \mathrm{L} \quad 9.60 \mathrm{E}+00$ EPIA-013

$\mathrm{pCi} / \mathrm{L} \quad 8.67 \mathrm{E}+00$ EPIA-013

$\mathrm{pCi} / \mathrm{L}$ 4.56E+00 EPIA-013

$\mathrm{pCi} / \mathrm{L} \quad 4.97 \mathrm{E}+00$ EPIA-013

$\mathrm{pCi} / \mathrm{L} \quad 2.27 \mathrm{E}+01$ EPIA-013

$\mathrm{pCi} / \mathrm{L}$ 2.32E+01 EPIA-013

$\mathrm{pCi} / \mathrm{L} 3.23 \mathrm{E}+00$ EPIA -013

$\mathrm{pCi} / \mathrm{L} \quad 3.16 \mathrm{E}+00$ EPIA-013

$\mathrm{pCi} / \mathrm{L} \quad 3.86 \mathrm{E}+00$ EPIA-013

$\mathrm{pCi} / \mathrm{L} \quad 3.94 \mathrm{E}+00$ EPIA-013

$\mathrm{pCi} / \mathrm{L} \quad 3.08 \mathrm{E}+00$ EPIA-013

$\mathrm{pCi} / \mathrm{L} \quad 2.96 \mathrm{E}+00$ EPIA-013

$\mathrm{pCi} / \mathrm{L} \quad 3.98 \mathrm{E}+00$ EPIA-013

$\mathrm{pCi} / \mathrm{L} \quad 3.67 \mathrm{E}+00$ EPIA-013

pCi/L 4.02E+00 EPIA-013

$\mathrm{pCi} / \mathrm{L} \quad 4.03 \mathrm{E}+00$ EPIA-013

$\mathrm{pCi} / 2.33 \mathrm{E}-01$ EPIA-011

$\mathrm{pCi} / \mathrm{L}$ 3.20E-01 EPIA-011

$\mathrm{pCi} / \mathrm{L} \quad 1.62 \mathrm{E}-01$ EPIA-011

$\mathrm{pCi} / \mathrm{L}$ 1.69E-01 EPIA-011

$\mathrm{pCi} / \mathrm{L}$ 9.12E-02 EPIA-011

$\mathrm{pCi} / \mathrm{L}$ 9.53E-02 EPIA-011

$\mathrm{pCi} / \mathrm{L} \quad 9.35 \mathrm{E}+00$ EPIA-013

$\mathrm{PCi} / \mathrm{L}$ 9.78E+00 EPIA-013

$\mathrm{pCi} / \mathrm{L}$ 1.02E+01 EPIA-013

$\mathrm{pCi} / \mathrm{L} \quad 1.15 \mathrm{E}+01$ EPIA-013

$\mathrm{pCi} / \mathrm{L} \quad 1.32 \mathrm{E}+01$ EPIA-013

$\mathrm{pCi} / \mathrm{L} \quad 1.32 \mathrm{E}+01$ EPIA-013

$\mathrm{pCi} / \mathrm{L} \quad 1.23 \mathrm{E}+00$ EPIA-001

$\mathrm{pCi} / \mathrm{L} \quad 1.16 \mathrm{E}+00$ EPIA-006

$\mathrm{pCi} / \mathrm{L} \quad 6.80 \mathrm{E}+00$ EPIA-013

$\mathrm{pCi} / 5.45 \mathrm{E}+00$ EPIA-013

$\mathrm{pCi} / \mathrm{L} \quad 3.61 \mathrm{E}+00$ EPIA-013

$\mathrm{pCi} / \mathrm{L} \quad 3.63 \mathrm{E}+00$ EPIA-013

$\mathrm{pCi} / \mathrm{L}$ 9.80E-02 EPIA-032

$\mathrm{pCi} / \mathrm{L} \quad 2.32 \mathrm{E}+01$ EPIA-013

$\mathrm{pCi} / \mathrm{L} \quad 2.34 \mathrm{E}+01$ EPIA-013

$\mathrm{pCi} / \mathrm{L} 2.53 \mathrm{E}+02$ EPIA-022

$\mathrm{pCi} / \mathrm{L} \quad 2.05 \mathrm{E}+00$ EPIA-001

$\mathrm{pCi} / \mathrm{L} \quad 4.96 \mathrm{E}+01$ EPIA-013

$\mathrm{pCi} / \mathrm{L} \quad 4.80 \mathrm{E}+01$ EPIA-013

Data Summary Report for the Annual Fourmile Branch and

F- and H-Area Seeplines, Appendix IX Metals and Radionuclides, 1998

(WSRC-TR-98-00260) 
SURVEY ID: FSP 03203 (cont.)

Constituent

Radionuclides

Promethium-144

Promethium-144

Promethium-146

Promethium-146

Radium-226

Radium-228

Ruthenium-106

Ruthenium-106

Sodium-22

Sodium-22

Tin-113

Tin-113

Tritium

Uranium-233/234

Uranium-233/234

Uranium-235

Uranium-235

Uranium-238

Uranium-238

Yttrium-88

Yttrium-88

Zinc-65

Zinc-65

Zirconium-95

Zirconium-95

SURVEY ID: FSP 03203D

Sample type: Split

Constituent

Specified Analyses

Chloride

Cyanide

Hardness as $\mathrm{CACO} 3$

Hardness as CACO 3

Nitrate as nitrogen

Nitrate-nitrite as nitrogen

Metals (total recoverable)

Aluminum
Antimony
Arsenic
Barium
Beryllium
Cadmium
Calcium
Chromium
Cobalt
Copper
Iron

Sample ID: 114021

RQ AQ B Result
$-1.58 \mathrm{E}-01$
$-1.35 \mathrm{E}+00$
$-5.05 \mathrm{E}-01$
$9.72 \mathrm{E}-01$
6.67E-01
1.05E-01
$9.02 \mathrm{E}+00$
$3.44 \mathrm{E}+00$
$6.74 \mathrm{E}-03$
$1.28 \mathrm{E}+00$
2.92E-01
$1.65 \mathrm{E}+00$
$8.82 \mathrm{E}+01$
$2.67 \mathrm{E}-01$
2.38E-01
5.25E-02
$1.09 \mathrm{E}-03$
4.61E-01
1.09E-03
9.57E-01
7.71E-01
$-3.40 \mathrm{E}+00$
$3.36 \mathrm{E}+00$
$2.26 \mathrm{E}+00$
$-4.65 \mathrm{E}-01$

Sample ID: 114022
Unit ssMDL Method

pCi/L 3.41E+00 EPIA-013 $\mathrm{pCi} / \mathrm{L} \quad 3.10 \mathrm{E}+00$ EPIA-013 $\mathrm{pCi} / \mathrm{L} \quad 4.57 \mathrm{E}+00$ EPIA-013 $\mathrm{pCi} / \mathrm{L} \quad 4.51 \mathrm{E}+00$ EPIA-013 $\mathrm{pCi} / \mathrm{L}$ 4.86E-01 EPIA-008 $\mathrm{pCi} / \mathrm{L} \quad 1.02 \mathrm{E}+00$ EPIA-009 pCi/L 3.29E+01 EPIA-013 $\mathrm{pCi} / \mathrm{L} \quad 3.02 \mathrm{E}+01$ EPIA-013 $\mathrm{pCi} / \mathrm{L} \quad 3.63 \mathrm{E}+00$ EPIA-013 $\mathrm{pCi} / \mathrm{L} \quad 4.11 \mathrm{E}+00$ EPIA-013 $\mathrm{pCi} / \mathrm{L} \quad 4.52 \mathrm{E}+00$ EPIA-013 $\mathrm{pCi} / \mathrm{L} \quad 4.67 \mathrm{E}+00$ EPIA-013 pCi/mL6.12E-01 EPA906.0 $\mathrm{pCi} / \mathrm{L}$ 8.91E-02 EPIA-01 1 $\mathrm{pCi} / \mathrm{L}$ 1.43E-01 EPIA-011 $\mathrm{pCi} / \mathrm{L}$ 1.57E-01 EPIA-011 $\mathrm{pCi} / \mathrm{L}$ 2.06E-01 EPIA-011 $\mathrm{pCi} / \mathrm{L}$ 1.85E-01 EPIA-011 $\mathrm{pCi} / \mathrm{L}$ 2.05E-01 EPIA-011 $\mathrm{pCi} / \mathrm{L} \quad 4.72 \mathrm{E}+00$ EPIA-013 $\mathrm{pCi} / \mathrm{L} \quad 4.87 \mathrm{E}+00$ EPIA-013 $\mathrm{pCi} / \mathrm{L} \quad 6.55 \mathrm{E}+00$ EPIA-013 $\mathrm{pCi} / \mathrm{L} \quad 8.02 \mathrm{E}+00$ EPIA-013 $\mathrm{pCi} / \mathrm{L} \quad 7.28 \mathrm{E}+00$ EPIA-013 $\mathrm{pCi} / \mathrm{L} \quad 6.35 \mathrm{E}+00$ EPIA-013
RQ AQ B Result

$\begin{array}{lll} & & 2100 \\ \mathrm{U} & & 15.2 \\ & & 12000 \\ & & 11500 \\ \mathrm{~J} & \mathrm{Q} & 1760 \\ & & 1500\end{array}$

$\begin{array}{lll} & & 785 \\ \mathrm{U} & & 27 \\ \mathrm{U} & & 40 \\ & \mathrm{~V} & 104 \\ \mathrm{~J} & \mathrm{E} & 0.21 \\ & & 7.1 \\ & & 824 \\ & & 0.93 \\ & & 156 \\ & & 15 \\ & & 623\end{array}$

Unit ssMDL Method

$\begin{array}{lll}\mu \mathrm{g} / \mathrm{L} & 21 & \text { EPA9056 } \\ \mu \mathrm{g} / \mathrm{L} & 1.52 & \text { EPA9010A } \\ \mu \mathrm{g} / \mathrm{L} & 900 & \mathrm{EPA130.2} \\ \mu \mathrm{g} / \mathrm{L} & 900 & \mathrm{EPA130.2} \\ \mu \mathrm{g} / \mathrm{L} & 20 & \mathrm{EPA353.2} \\ \mu \mathrm{g} / \mathrm{L} & 20 & \mathrm{EPA353.2}\end{array}$

$\begin{array}{lll}\mu \mathrm{g} / \mathrm{L} & 14.6 & \text { EPA6010 } \\ \mu \mathrm{g} / \mathrm{L} & 2.7 & \text { EPA6010 } \\ \mu \mathrm{g} / \mathrm{L} & 4 & \text { EPA6010 } \\ \mu \mathrm{g} / \mathrm{L} & 0.18 & \text { EPA6010 } \\ \mu \mathrm{g} / \mathrm{L} & 0.16 & \text { EPA6010 } \\ \mu \mathrm{g} / \mathrm{L} & 0.47 & \text { EPA6010 } \\ \mu \mathrm{g} / \mathrm{L} & 47.1 & \text { EPA6010 } \\ \mu \mathrm{g} / \mathrm{L} & 0.7 & \text { EPA6010 } \\ \mu \mathrm{g} / \mathrm{L} & 0.45 & \text { EPA6010 } \\ \mu \mathrm{g} / \mathrm{L} & 1.5 & \text { EPA6010 } \\ \mu \mathrm{g} / \mathrm{L} & 7.4 & \text { EPA6010 }\end{array}$

Data Summary Report for the Annual Fourmile Branch and

F- and H-Area Seeplines, Appendix IX Metals and Radionuclides, 1998

(WSRC-TR-98-00260) 
SURVEY ID: FSP 03203D (cont.)

Constituent

Metals (total recoverable)

Lead

Magnesium

Manganese

Mercury

Nickel

Potassium

Selenium

Silver

Sodium

Thallium

Tin

Vanadium

Zinc

Radionuclides

Actinium-228
Antimony-124
Antimony-125
Barium-133
Cerium-144
Cesium-134
Cesium-137
Cobalt-57
Cobalt-58
Cobalt-60
Europium-152
Europium-154
Europium-155
Gross alpha
Iodine-129
Iodine-129
Lead-212
Manganese-54
Nickel-63
Nickel-63
Nonvolatile beta
Potassium-40
Promethium-144
Promethium-146
Radium-228
Radium-228
Ruthenium-106
Sodium-22
Strontium-90
Strontium-90
Tin-113
Tritium
Yttrium-88
Zinc-65
Zirconium-95

Sample ID: 114022
RQ AQ B Result

$\begin{array}{llllll} & & 89.5 & \mu g / \mathrm{L} & 4.7 & \text { EPA6010 } \\ & \mathrm{V} & 422 & \mu \mathrm{g} / \mathrm{L} & 7.4 & \text { EPA6010 } \\ & & 454 & \mu \mathrm{g} / \mathrm{L} & 0.78 & \text { EPA6010 } \\ \mathrm{U} & & 0.7 & \mu \mathrm{g} / \mathrm{L} & 0.07 & \text { EPA7470 } \\ & & 92.6 & \mu \mathrm{L} / \mathrm{L} & 2.6 & \text { EPA6010 } \\ \mathrm{J} & \mathrm{E} & 141 & \mu \mathrm{g} / \mathrm{L} & 18.7 & \text { EPA6010 } \\ \mathrm{U} & & 66 & \mu \mathrm{g} / \mathrm{L} & 6.6 & \text { EPA6010 } \\ \mathrm{U} & & 5 & \mu \mathrm{g} / \mathrm{L} & 0.5 & \text { EPA6010 } \\ & \mathrm{V} & 2620 & \mu \mathrm{g} / \mathrm{L} & 28.5 & \text { EPA6010 } \\ \mathrm{U} & & 55 & \mu \mathrm{g} / \mathrm{L} & 5.5 & \text { EPA6010 } \\ \mathrm{U} & & 70 & \mu \mathrm{g} / \mathrm{L} & 7 & \text { EPA6010 } \\ \mathrm{U} & & 6.9 & \mu \mathrm{L} / \mathrm{L} & 0.69 & \text { EPA6010 } \\ \mathrm{J} & \mathrm{E} & 35.8 & \mu \mathrm{g} / \mathrm{L} & 5.3 & \text { EPA6010 }\end{array}$

Unit ssMDL Method

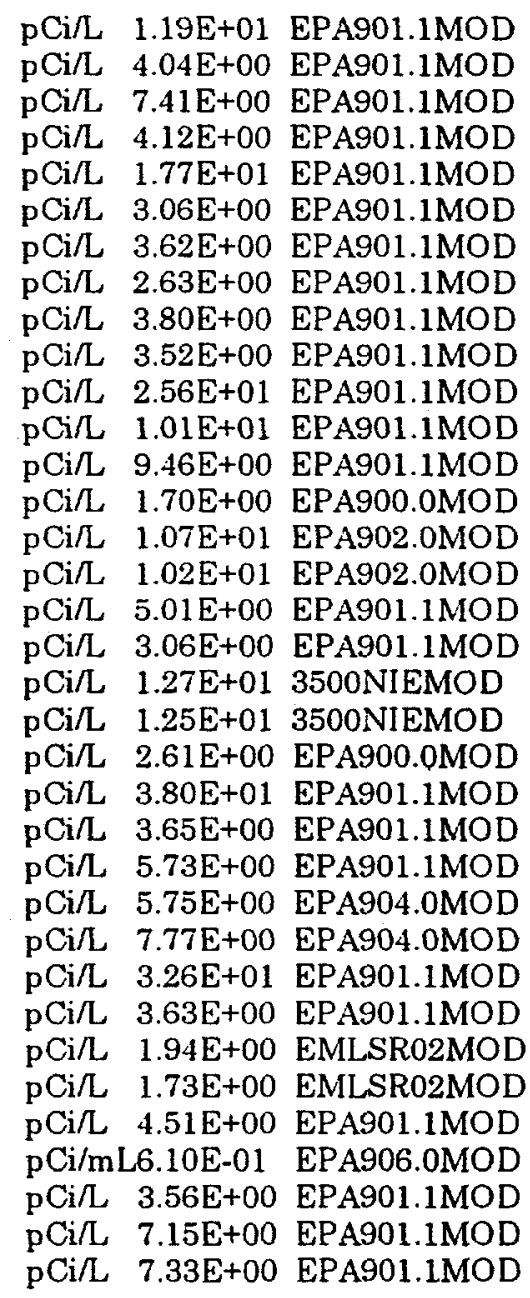


Survey location: 50607E 73609N (SRS coordinates)

Ground elevation above MSL: . ft

Sample type: Normal

Sample matrix: Water

Constituent

RQ AQ B Result

Unit ssMDL Method

Specified Analyses

Chloride

Cyanide

Hardness as $\mathrm{CACO} 3$

Nitrate as nitrogen

Nitrate-nitrite as nitrogen

Metals (total recoverable)

$\begin{array}{cll} & \mathrm{V} & 3560 \\ \mathrm{U} & & 10 \\ & 5000 \\ \mathrm{~V} & 440 \\ \mathrm{~V} & 500\end{array}$

553

10

5

91.7

Barium

Beryllium

Cadmium

Calcium

Chromium

Cobalt

Copper

Iron

Lead

Magnesium

Manganese

Mercury

Nickel

Potassium

Selenium

Silver

Sodium

Thallium

Tin

Vanadium

Zinc

$\begin{array}{lll}\text { U } & & 553 \\ U & & 5 \\ & & 91.7 \\ U & & 5 \\ U & & 5 \\ & V & 355 \\ J & E & 1.07 \\ J & E & 3.74 \\ U & & 5 \\ & V & 3910 \\ J & E & 2.52 \\ & V & 586 \\ & & 220 \\ U & & 0.2 \\ U & & 5 \\ J & E & 37.8 \\ U & & 5 \\ U & V & 1.09 \\ & & 2720 \\ U & & 10 \\ U & & 10 \\ J & E & 1.55 \\ & & 18.2\end{array}$

Radionuclides

Actinium-228

Antimony-124

Antimony-125

Barium-133

Cerium-144

Cesium-134

Cesium-137

Cobalt-57

Cobalt-58

Cobalt-60

Europium-152

Europium-154

Europium-155

Gross alpha

Lead-212

$\begin{array}{ll}\text { UI } & 6.59 \mathrm{E}+00 \\ \text { UI } & -4.65 \mathrm{E}-01 \\ \text { UI } & 3.04 \mathrm{E}+00 \\ \text { UI } & -9.69 \mathrm{E}-02 \\ \text { UI } & 9.46 \mathrm{E}+00 \\ \text { UI } & -1.94 \mathrm{E}-01 \\ \text { UI } & -8.00 \mathrm{E}-01 \\ \text { UI } & 7.42 \mathrm{E}-02 \\ \text { UI } & 1.08 \mathrm{E}+00 \\ \text { UI } & 6.24 \mathrm{E}-01 \\ \text { UI } & -5.41 \mathrm{E}+00 \\ \text { UI } & -1.06 \mathrm{E}+00 \\ \text { UI } & 1.71 \mathrm{E}+00 \\ & 3.92 \mathrm{E}+00 \\ & 6.97 \mathrm{E}+00\end{array}$

$\begin{array}{lll}\mu \mathrm{g} / \mathrm{L} & 7 & \mathrm{EPA300.0} \\ \mu \mathrm{g} / \mathrm{L} & 3.34 & \mathrm{EPA335.3} \\ \mu \mathrm{g} / \mathrm{L} & 1000 . & \text { EPA130.2 } \\ \mu \mathrm{g} / \mathrm{L} & 6 & \text { EPA300.0 } \\ \mu \mathrm{g} / \mathrm{L} & 7 & \text { EPA353.1 }\end{array}$

$\begin{array}{lll}\mu \mathrm{g} / \mathrm{L} & 37.6 & \text { EPA6010A } \\ \mu \mathrm{g} / \mathrm{L} & 1.64 & \text { EPA6010A } \\ \mu \mathrm{g} / \mathrm{L} & 2.98 & \text { EPA6010A } \\ \mu \mathrm{g} / \mathrm{L} & 0.332 & \text { EPA6010A } \\ \mu \mathrm{g} / \mathrm{L} & 0.223 & \text { EPA6010A } \\ \mu \mathrm{g} / \mathrm{L} & 0.208 & \text { EPA6010A } \\ \mu \mathrm{g} / \mathrm{L} & 15.4 & \text { EPA6010A } \\ \mu \mathrm{g} / \mathrm{L} & 0.729 & \text { EPA6010A } \\ \mu \mathrm{g} / \mathrm{L} & 0.671 & \text { EPA6010A } \\ \mu \mathrm{g} / \mathrm{L} & 1.32 & \text { EPA6010A } \\ \mu \mathrm{g} / \mathrm{L} & 8.63 & \text { EPA6010A } \\ \mu \mathrm{g} / \mathrm{L} & 0.678 & \text { EPA6010A } \\ \mu \mathrm{g} / \mathrm{L} & 3.33 & \text { EPA6010A } \\ \mu \mathrm{g} / \mathrm{L} & 0.903 & \text { EPA6010A } \\ \mu \mathrm{g} / \mathrm{L} & 0.104 & \text { EPA7470 } \\ \mu \mathrm{g} / \mathrm{L} & 2.27 & \text { EPA6010A } \\ \mu \mathrm{g} / \mathrm{L} & 5.87 & \text { EPA6010A } \\ \mu \mathrm{g} / \mathrm{L} & 1.4 & \text { EPA6010A } \\ \mu \mathrm{g} / \mathrm{L} & 0.62 & \text { EPA6010A } \\ \mu \mathrm{g} / \mathrm{L} & 29.1 & \text { EPA6010A } \\ \mu \mathrm{g} / \mathrm{L} & 2.63 & \text { EPA6010A } \\ \mu \mathrm{g} / \mathrm{L} & 2.94 & \text { EPA6010A } \\ \mu \mathrm{g} / \mathrm{L} & 0.427 & \text { EPA6010A } \\ \mu \mathrm{g} / \mathrm{L} & 0.966 & \text { EPA6010A }\end{array}$

$\mathrm{pCi} / \mathrm{L} \quad 1.43 \mathrm{E}+01$ EPIA-013

$\mathrm{pCi} / \mathrm{L} \quad 3.72 \mathrm{E}+00$ EPIA-013

$\mathrm{pCi} / \mathrm{L} \quad 9.89 \mathrm{E}+00$ EPIA-013

$\mathrm{pCi} / \mathrm{L}$ 4.32E+00 EPIA-013

$\mathrm{pCi} / \mathrm{L} \quad 2.31 \mathrm{E}+01$ EPIA-013

$\mathrm{pCi} / \mathrm{L} \quad 3.28 \mathrm{E}+00$ EPIA-013

$\mathrm{pCi} / \mathrm{L} \quad 3.59 \mathrm{E}+00$ EPIA-013

$\mathrm{pCi} / \mathrm{L} \quad 2.92 \mathrm{E}+00$ EPIA-013

$\mathrm{pCi} / \mathrm{L}$ 4.01E+00 EPIA-013

$\mathrm{pCi} / \mathrm{L} \quad 3.51 \mathrm{E}+00$ EPIA-013

$\mathrm{pCi} / \mathrm{L} \quad 8.45 \mathrm{E}+00$ EPIA-013

$\mathrm{pCi} / \mathrm{L} \quad 1.13 \mathrm{E}+01$ EPIA-013

$\mathrm{pCi} / \mathrm{L} \quad 1.30 \mathrm{E}+01$ EPIA-013

$\mathrm{pCi} / \mathrm{L}$ 7.35E-01 EPIA-001

$\mathrm{pCi} / \mathrm{L} \quad 5.31 \mathrm{E}+00$ EPIA-013 
SURVEY ID: FSP 04703 (cont.)

Constituent

Radionuclides

$\begin{array}{lll}\text { Manganese-54 } & \text { UI } & 9.39 \mathrm{E}-01 \\ \text { Neptunium-239 } & \text { UI } & -7.51 \mathrm{E}+00 \\ \text { Nonvolatile beta } & & 3.25 \mathrm{E}+01 \\ \text { Potassium-40 } & \text { UI } & 2.93 \mathrm{E}+01 \\ \text { Promethium-144 } & \text { UI } & -3.19 \mathrm{E}-01 \\ \text { Promethium-146 } & \text { UI } & -8.42 \mathrm{E}-01 \\ \text { Ruthenium-106 } & \text { UI } & 1.56 \mathrm{E}+00 \\ \text { Sodium-22 } & \text { UI } & -3.79 \mathrm{E}-01 \\ \text { Tin-113 } & \text { UI } & -1.68 \mathrm{E}+00 \\ \text { Tritium } & & 2.31 \mathrm{E}+01 \\ \text { Yttrium-88 } & \text { UI } & 4.73 \mathrm{E}-01 \\ \text { Zinc-65 } & \text { UI } & -2.68 \mathrm{E}+00 \\ \text { Zirconium-95 } & \text { UI } & 9.74 \mathrm{E}-01\end{array}$

SURVEY ID: FSP 20403
Unit ssMDL Method

$\mathrm{pCi} / \mathrm{L} \quad 4.03 \mathrm{E}+00$ EPIA-013

$\mathrm{pCi} / \mathrm{L} \quad 2.15 \mathrm{E}+01$ EPIA-013

$\mathrm{pCi} / \mathrm{L} \quad 1.97 \mathrm{E}+00$ EPIA-001

$\mathrm{PCi} / \mathrm{L} \quad 4.92 \mathrm{E}+01$ EPIA-013

$\mathrm{pCi} / \mathrm{L} \quad 3.56 \mathrm{E}+00$ EPIA-013

$\mathrm{pCi} / \mathrm{L} \quad 3.99 \mathrm{E}+00$ EPIA-013

$\mathrm{pCi} / \mathrm{L} \quad 3.35 \mathrm{E}+01$ EPIA-013

$\mathrm{pCi} / \mathrm{L} \quad 4.04 \mathrm{E}+00$ EPIA-013

$\mathrm{pCi} / \mathrm{L} \quad 4.29 \mathrm{E}+00$ EPIA-013

$\mathrm{pCi} / \mathrm{mL6.08E-01} \mathrm{EPA906.0}$

$\mathrm{pCi} / \mathrm{L} \quad 3.84 \mathrm{E}+00$ EPIA-013

$\mathrm{PCi} / \mathrm{L} \quad 7.51 \mathrm{E}+00$ EPIA-013

$\mathrm{pCi} / \mathrm{L}$ 6.76E+00 EPIA-013

Survey location: 48801E $73281 \mathrm{~N}$ (SRS coordinates)

Ground elevation above MSL: . $\mathrm{ft}$

Sample type: Normal

Sample matrix: Water

Constituent

Specified Analyses

Chloride

Cyanide

Hardness as $\mathrm{CACO} 3$

Nitrate as nitrogen

Nitrate-nitrite as nitrogen

Metals (total recoverable)

Aluminum

Antimony

Arsenic

Barium

Beryllium

Cadmium

Calcium

Chromium

Cobalt

Copper

Iron

Lead

Magnesium

Manganese

Mercury

Nickel

Potassium

Selenium

Silver

Sodium

Thallium
RQ AQ B Result

$\begin{array}{ll}\text { V } & 1610 \\ & 10 \\ & 26500 \\ \mathrm{~V} & 34200 \\ \mathrm{~V} & 35800\end{array}$

$\begin{array}{ll}\mu \mathrm{g} / \mathrm{L} & 7 \\ \mu \mathrm{g} / \mathrm{L} & 3.34\end{array}$

$\mu \mathrm{g} / \mathrm{L} \quad 1000$

$\mu \mathrm{g} / \mathrm{L} \quad 600$

$\mu \mathrm{g} / \mathrm{L} \quad 175$

$\mu \mathrm{g} \Omega \quad 75.2$

$\mu \mathrm{g} / \mathrm{L} \quad 3.28$

$\mu \mathrm{g} / \mathrm{L} \quad 5.96$

$\mu \mathrm{g} / \mathrm{L} \quad 0.664$

$\mu \mathrm{g} / \mathrm{L} \quad 0.446$

$\mu \mathrm{g} / \mathrm{L} \quad 0.416$

$\mu \mathrm{g} / \mathrm{L} \quad 30.8$

$\mu \mathrm{g} / \mathrm{L} \quad 1.46$

$\mu \mathrm{g} / \mathrm{L} \quad 1.34$

$\mu \mathrm{g} / \mathrm{L} \quad 2.64$

$\mu \mathrm{g} / \mathrm{L} \quad 17.3$

$\mu \mathrm{g} / \mathrm{L} \quad 1.36$

$\mu \mathrm{g} / \mathrm{L} \quad 6.66$

$\mu \mathrm{g} / \quad 1.81$

$\mu \mathrm{g} / \mathrm{L} \quad 0.104$

$\mu \mathrm{g} / \mathrm{L} \quad 4.54$

$\mu \mathrm{g} / \mathrm{L} \quad 11.7$

$\mu g / L \quad 2.8$

$\mu \mathrm{g} / \mathrm{L} \quad 1.24$

$\mu \mathrm{g} / \mathrm{L} \quad 58.2$

$\mu \mathrm{g} / \mathrm{L} \quad 5.26$
EPA300.0

EPA335.3

EPA130.2

EPA300.0

EPA353.1

EPA6010A EPA6010A EPA6010A EPA6010A EPA6010A EPA6010A EPA6010A EPA6010A EPA6010A EPA6010A EPA6010A EPA6010A EPA6010A EPA6010A EPA7470

EPA6010A EPA6010A EPA6010A EPA6010:A EPA6010A EPA6010A 
SURVEY ID: FSP 20403 (cont.)

Constituent

Metals (lotal recoverable)

Tin

Vanadium

Zinc

$\begin{array}{ll}\mathrm{U} & 20 \\ \mathrm{U} & 10 \\ & 25.1\end{array}$

Radionuclides

Actinium-228

Americium-241

Antimony-124

Antimony-125

Barium-133

Cerium-144

Cesium-134

Cesium-137

Cobalt-57

Cobalt-58

Cobalt-60

Curium-242

Curium-243/244

Curium-245/246

Europium-152

Europium-154

Europium-155

Gross alpha

lodine-129

lodine-129

Lead-212

Manganese-54

Neptunium-237

Neptunium-237

Neptunium-239

Nickel-63

Nonvolatile beta

Potassium-40

Promethium-144

Promethium-146

Radium-226

Radium-228

Ruthenium-106

Sodium-22

Tin-113

Tritium

Uranium-233/234

Uranium-235

Uranium-238

Yttrium-88

Zinc-65

Zirconium-95
Sample ID: 114018

RQ AQ B Result

Unit ssMDL Method

$\mu \mathrm{g} / \mathrm{L} \quad 5.88$

$\mu \mathrm{g} / \mathrm{L} \quad 0.854$

$\mu \mathrm{g} / \mathrm{L} \quad 1.93$

EPA6010A

EPA6010A

EPA6010A

$\mathrm{pCi} / \mathrm{L} \quad 1.67 \mathrm{E}+01$ EPIA-013

$\mathrm{pCi} / \mathrm{L}$ 1.83E-01 EPIA-011

$\mathrm{pCi} / \mathrm{L}$ 4.07E+00 EPIA-013

$\mathrm{pCi} / \mathrm{L} \quad 8.68 \mathrm{E}+00$ EPIA-013

$\mathrm{pCi} / \mathrm{L} \quad 4.27 \mathrm{E}+00$ EPIA-013

$\mathrm{pCi} / \mathrm{L}$ 2.28E+01 EPIA-013

pCi/L 3.21E+00 EPIA-013

$\mathrm{pCi} / \mathrm{L} \quad 3.22 \mathrm{E}+00$ EPIA-013

$\mathrm{pCi} / \mathrm{L} \quad 3.07 \mathrm{E}+00$ EPIA-013

$\mathrm{pCi} / \mathrm{L} \quad 3.61 \mathrm{E}+00$ EPIA-013

$\mathrm{pCi} / \mathrm{L} \quad 4.55 \mathrm{E}+00$ EPIA-013

$\mathrm{pCi} / \mathrm{L} \quad 1.51 \mathrm{E}-01$ EPIA-011

$\mathrm{pCi} / \mathrm{L}$ 1.85E-01 EPIA-011

$\mathrm{pCi} / \mathrm{L} \quad 1.04 \mathrm{E}-01$ EPIA-011

$\mathrm{pCi} / \mathrm{L} \quad 8.99 \mathrm{E}+00$ EPIA-013

$\mathrm{pCi} / \mathrm{L} \quad 7.75 \mathrm{E}+00$ EPIA-013

$\mathrm{pCi} / \mathrm{L} \quad 1.28 \mathrm{E}+01$ EPIA-013

pCi/L 1.60E+00 EPIA-001

$\mathrm{pCi} / \mathrm{L} \quad 1.91 \mathrm{E}+00$ EPIA-006

$\mathrm{pCi} / \mathrm{L}$ 8.79E-01 EPIA-006

pCi/L 6.27E+00 EPIA-013

pCi/L 3.33E+00 EPIA-013

pCi/L 8.80E-02 EPIA-032

pCi/L 8.60E-02 EPIA-032

$\mathrm{pCi} / \mathrm{L} \quad 2.25 \mathrm{E}+01$ EPIA-013

$\mathrm{pCi} / \mathrm{L} \quad 2.20 \mathrm{E}+02$ EPIA-022

$\mathrm{pCi} / \mathrm{L} \quad 2.21 \mathrm{E}+00$ EPIA-001

$\mathrm{pCi} / \mathrm{L} \quad 4.17 \mathrm{E}+01$ EPIA-013

pCi/L 3.59E+00 EPIA-013

$\mathrm{pCi} / \mathrm{L} \quad 4.06 \mathrm{E}+00$ EPIA-013

$\mathrm{pCi} / \mathrm{L} \quad 1.77 \mathrm{E}-01$ EPIA-008

pCi/L 1.01E+00 EPIA-009

$\mathrm{pCi} / \mathrm{L} \quad 3.01 \mathrm{E}+01$ EPIA-013

$\mathrm{pCi} / \mathrm{L} \quad 2.77 \mathrm{E}+00$ EPIA-013

$\mathrm{pCi} / \mathrm{L} \quad 4.19 \mathrm{E}+00$ EPIA-013

$\mathrm{pCi} / \mathrm{mL} 2.92 \mathrm{E}+00$ EPA906.0

pCi/L 1.83E-01 EPIA-011

$\mathrm{pCi} / \mathrm{L}$ 1.56E-01 EPIA-011

pCi/L 1.55E-01 EPIA-011

$\mathrm{pCi} / \mathrm{L}$ 4.53E+00 EPIA-013

$\mathrm{pCi} / \mathrm{L} \quad 6.39 \mathrm{E}+00$ EPIA-013

$\mathrm{pCi} / \mathrm{L} \quad 5.80 \mathrm{E}+00$ EPIA-013

Data Summary Report for the Annual Fourmile Branch and

F- and H-Area Seeplines, Appendix IX Metals and Radionuclides, 1998

(WSRC-TR-98-00260) 
Survey location: 46865E 73160N (SRS coordinates)

Ground elevation above MSL: . ft

Sample type: Normal

Sample matrix: Water

\section{Constituent}

Specified Analyses
RQ AQ B Result

Metals (lolal recoverable)
Unit ssMDL Method

\begin{tabular}{|c|c|c|c|c|c|}
\hline Chloride & $\mathrm{V}$ & 2020 & $\mu \mathrm{g} / \mathrm{L}$ & 7 & EPA300.0 \\
\hline Chloride & $\mathrm{V}$ & 1900 & $\mu \mathrm{g} / \mathrm{L}$ & 7 & EPA300.0 \\
\hline Cyanide & U & 10 & $\mu g / L$ & 3.34 & EPA335.3 \\
\hline Hardness as $\mathrm{CACO} 3$ & & 12500 & $\mu \mathrm{g} / \mathrm{L}$ & 1000 & EPA 130.2 \\
\hline Nitrate as nitrogen & $\mathrm{V}$ & 206 & $\mu \mathrm{g} / \mathrm{L}$ & 6 & EРА 300.0 \\
\hline Nitrate as nitrogen & $\mathrm{V}$ & 208 & $\mu \mathrm{g} / \mathrm{L}$ & 6 & EPA300.0 \\
\hline Nitrate-nitrite as nitrogen & $\mathrm{V}$ & 280 & $\mu \mathrm{g} / \mathrm{L}$ & 7 & EPA353.1 \\
\hline
\end{tabular}

\begin{tabular}{|c|c|c|c|c|c|c|}
\hline Aluminum & & & 391 & $\mu g / L$ & 37.6 & EPA6010A \\
\hline Antimony & $\mathrm{U}$ & & 10 & $\mu \mathrm{g} / \mathrm{L}$ & 1.64 & EPA6010A \\
\hline Arsenic & $\mathrm{U}$ & & 5 & $\mu \mathrm{g} / \mathrm{L}$ & 2.98 & EPA6010A \\
\hline Barium & & & 30.4 & $\mu \mathrm{g} / \mathrm{L}$ & 0.332 & EPA6010A \\
\hline Beryllium & $\mathrm{U}$ & & 5 & $\mu \mathrm{g} / \mathrm{L}$ & 0.223 & EPA6010A \\
\hline Cadmium & $\mathrm{U}$ & & 5 & $\mu \mathrm{g} / \mathrm{L}$ & 0.208 & EPA6010A \\
\hline Calcium & & V & 742 & $\mu \mathrm{g} / \mathrm{L}$ & 15.4 & EPA6010A \\
\hline Chromium & $\mathrm{U}$ & & 5 & $\mu g / L$ & 0.729 & EPA6010A \\
\hline Cobalt & $J$ & $E$ & 0.996 & $\mu g / L$ & 0.671 & EPA6010A \\
\hline Copper & $\mathrm{U}$ & & 5 & $\mu \mathrm{g} / \mathrm{L}$ & 1.32 & EPA6010A \\
\hline Iron & & $\mathrm{V}$ & 1730 & $\mu \mathrm{g} / \mathrm{L}$ & 8.63 & EPA6010A \\
\hline Lead & $\mathrm{U}$ & & 5 & $\mu \mathrm{g} / \mathrm{L}$ & 0.678 & EPA6010A \\
\hline Magnesium & & $\mathrm{V}$ & 420 & $\mu \mathrm{g} / \mathrm{L}$ & 3.33 & EPA6010A \\
\hline Manganese & & & 65.1 & $\mu \mathrm{g} / \mathrm{L}$ & 0.903 & EPA6010A \\
\hline Mercury & $\mathrm{U}$ & & 0.2 & $\mu \mathrm{g} / \mathrm{L}$ & 0.104 & EPA7470 \\
\hline Nickel & U & & 5 & $\mu \mathrm{g} / \mathrm{L}$ & 2.27 & EPA6010A \\
\hline Potassium & & & 114 & $\mu \mathrm{g} / \mathrm{L}$ & 5.87 & EPA6010A \\
\hline Selenium & $U$ & & 5 & $\mu \mathrm{g} / \mathrm{L}$ & 1.4 & EPA6010A \\
\hline Silver & $U$ & V & 1.41 & $\mu \mathrm{g} / \mathrm{L}$ & 0.62 & EPA6010A \\
\hline Sodium & & & 1900 & $\mu \mathrm{g} / \mathrm{L}$ & 29.1 & EPA6010A \\
\hline Thallium & $U$ & & 10 & $\mu \mathrm{g} / \mathrm{L}$ & 2.63 & EPA6010A \\
\hline Tin & $\mathrm{U}$ & & 10 & $\mu \mathrm{g} / \mathrm{L}$ & 2.94 & EPA6010A \\
\hline Vanadium & $J$ & $\mathrm{E}$ & 0.977 & $\mu \mathrm{g} / \mathrm{L}$ & 0.427 & EPA6010A \\
\hline Zine & & & 12.1 & $\mu g / L$ & 0.966 & EPA6010A \\
\hline \multicolumn{7}{|l|}{ Radionuclides } \\
\hline Actinium-228 & UI & & $7.43 \mathrm{E}-01$ & $\mathrm{pCi} / \mathrm{L}$ & $1.14 E+01$ & EPIA-013 \\
\hline Antimony-124 & UI & & $-2.08 \mathrm{E}+00$ & $\mathrm{pCi} / \mathrm{L}$ & $3.42 \mathrm{E}+00$ & EPIA-013 \\
\hline Antimony-125 & UI & & $-2.54 \mathrm{E}+00$ & $\mathrm{pCi} / \mathrm{L}$ & $8.09 \mathrm{E}+00$ & EPIA-013 \\
\hline Barium-133 & UI & & $-1.76 E+00$ & $\mathrm{pCi} / \mathrm{L}$ & $3.38 \mathrm{E}+00$ & EPIA-013 \\
\hline Cerium-144 & UI & & $-7.56 \mathrm{E}-01$ & $\mathrm{pCi} / \mathrm{L}$ & $2.03 E+01$ & EPIA-013 \\
\hline Cesium-134 & UI & & $1.67 \mathrm{E}+00$ & $\mathrm{pCi} / \mathrm{L}$ & $3.10 \mathrm{E}+00$ & EPIA-013 \\
\hline Cesium-137 & UI & & $1.96 \mathrm{E}+00$ & $\mathrm{pCi} / \mathrm{L}$ & $2.91 E+00$ & EPIA-013 \\
\hline Cobalt-57 & UI & & $1.62 \mathrm{E}-01$ & $\mathrm{pCi} / \mathrm{L}$ & $2.64 \mathrm{E}+00$ & EPIA-013 \\
\hline Cobalt-58 & UI & & $9.43 \mathrm{E}-01$ & $\mathrm{pCi} / \mathrm{L}$ & $3.38 \mathrm{E}+00$ & EPIA-013 \\
\hline Cobalt -60 & UI & & $3.60 \mathrm{E}-02$ & $\mathrm{pCi} / \mathrm{L}$ & $2.66 \mathrm{E}+00$ & EPIA-013 \\
\hline Europium-152 & UI & & $-1.57 E+00$ & $\mathrm{pCi} / \mathrm{L}$ & $7.93 \mathrm{E}+00$ & EPIA-013 \\
\hline Europium-154 & UI & & $-2.06 \mathrm{E}+00$ & $\mathrm{pCi} / \mathrm{L}$ & $7.30 \mathrm{E}+00$ & EPIA-013 \\
\hline Europium-155 & UI & & $-1.48 \mathrm{E}+00$ & $\mathrm{pCi} / \mathrm{L}$ & $1.10 \mathrm{E}+01$ & EPIA-013 \\
\hline
\end{tabular}

Data Summary Report for the Annual Fourmile Branch and

F- and H-Area Seeplines, Appendix IX Metals and Radionuclides, 1998

(WSRC-TR-98-00260) 
SURVEY ID: FSP 29003 (cont.)

Constituent

Radionuclides

Gross alpha

Lead-212

Manganese-54

Neptunium-239

Nonvolatile beta

Potassium -40

Promethium-144

Promethium-146

Ruthenium-106

Sodium-22

Tin-113

Tritium

Yttrium-88

Zinc-65

Zirconium-95

SURVEY ID: FSP 29003A

Sample type: Duplicate

Constituent

Specified Analyses
Sample ID: 114016

RQ AQ B Result

$4.24 \mathrm{E}+00$
$9.58 \mathrm{E}-03$
$1.45 \mathrm{E}+00$
$4.84 \mathrm{E}+00$
$7.61 \mathrm{E}+00$
$2.40 \mathrm{E}+01$
$-8.35 \mathrm{E}-01$
$-6.16 \mathrm{E}-01$
$-1.21 \mathrm{E}+00$
$-7.35 \mathrm{E}-01$
$1.56 \mathrm{E}+00$
$5.48 \mathrm{E}+01$
$7.67 \mathrm{E}-01$
$-2.98 \mathrm{E}+00$
$1.33 \mathrm{E}+00$

$4.24 \mathrm{E}+00$

UI

UI

UI

UI

UI

UI

UI

UI

UI

UI

UI

UI

$1.33 \mathrm{E}+00$
Unit ssMDL Method

$\mathrm{pCi} / \mathrm{L} \quad 1.24 \mathrm{E}+00$ EPIA-001

$\mathrm{pCi} / \mathrm{L} \quad 5.49 \mathrm{E}+00$ EPIA-013

$\mathrm{pCi} / \mathrm{L} \quad 2.14 \mathrm{E}+00$ EPIA-013

$\mathrm{pCi} / \mathrm{L} \quad 1.99 \mathrm{E}+01$ EPIA-013

$\mathrm{pCi} / \mathrm{L} \quad 2.16 \mathrm{E}+00$ EPIA-001

$\mathrm{pCi} / \mathrm{L} \quad 2.34 \mathrm{E}+01$ EPIA-013

pCi/ 2.69E +00 EPIA-013

$\mathrm{pCi} / \mathrm{L} \quad 3.43 \mathrm{E}+00$ EPIA -013

$\mathrm{pCi} / \mathrm{L} \quad 2.51 \mathrm{E}+01$ EPIA-013

$\mathrm{pCi} / \mathrm{L} \quad 2.62 \mathrm{E}+00$ EPIA-013

$\mathrm{pCi} / \mathrm{L} \quad 3.52 \mathrm{E}+00$ EPIA-013

pCi/mL6.35E-01 EPA906.0

$\mathrm{pCi} / \mathrm{L} \quad 3.95 \mathrm{E}+00$ EPIA-013

$\mathrm{pCi} / \mathrm{L} \quad 5.67 \mathrm{E}+00$ EPIA-013

$\mathrm{pCi} / \mathrm{L}$ 6.20E+00 EPIA-013

Sample ID: 114017

Associated sample: 114016

RQ AQ B Result

Unit ssMDL Method

$\begin{array}{lllll}\mathrm{U} & 1840 & \mu \mathrm{g} / \mathrm{L} & 7 & \text { EPA300.0 } \\ & 10 & \mu \mathrm{g} / \mathrm{L} & 3.34 & \text { EPA335.3 } \\ & 6700 & \mu \mathrm{g} / \mathrm{L} & 1000 & \text { EPA130.2 } \\ \mathrm{V} & 266 & \mu \mathrm{g} / \mathrm{L} & 6 & \text { EPA300.0 } \\ \mathrm{V} & 400 & \mu \mathrm{g} / \mathrm{L} & 7 & \text { EPA353.1 }\end{array}$

Metals (total recoverable)

Aluminum
Antimony
Arsenic
Barium
Beryllium
Cadmium
Calcium
Chromium
Cobalt
Copper
Iron
Lead
Magnesium
Manganese
Mercury
Nickel
Potassium
Selenium
Silver
Sodium
Thallium

Data Summary Report for the Annual Fourmile Branch and F- and H-Area Seeplines, Appendix IX Metals and Radionuclides, 1998

(WSRC-TR-98-00260) 
SURVEY ID: HSP 00803 (cont.)

Constituent

Metals (total recoverable)
Sample ID: 114006

RQ AQ B Result

Unit ssMDL Method

\begin{tabular}{|c|c|c|c|c|}
\hline Aluminum & $J$ & I & $\mathbf{L}$ & 3490 \\
\hline Antimony & $\mathrm{U}$ & & & 10 \\
\hline Arsenic & $\mathbf{U}$ & & & 5 \\
\hline Barium & & & & 14.1 \\
\hline Beryllium & $\mathbf{U}$ & & & 5 \\
\hline Cadmium & $\mathrm{U}$ & & & 5 \\
\hline Calcium & & V & & 849 \\
\hline Chromium & $\mathbf{J}$ & $\mathrm{E}$ & & 1.9 \\
\hline Cobalt & $\mathrm{U}$ & & & 5 \\
\hline Copper & $\mathrm{U}$ & & & 5 \\
\hline Iron & & & & 1630 \\
\hline Lead & $J$ & $\mathrm{E}$ & & 1.09 \\
\hline Magnesium & & V & & 814 \\
\hline Manganese & & & & 71.3 \\
\hline Mercury & $\mathrm{U}$ & & & 0.2 \\
\hline Nickel & $\mathrm{U}$ & & & 5 \\
\hline Potassium & & & & 169 \\
\hline Selenium & $\mathrm{U}$ & & & 5 \\
\hline Silver & $U$ & & & 5 \\
\hline Sodium & & V & & 13200 \\
\hline Thallium & $\mathrm{U}$ & & & 10 \\
\hline Tin & $\mathrm{U}$ & & & 10 \\
\hline Vanadium & $\mathrm{J}$ & $\mathrm{E}$ & & 4.59 \\
\hline Zinc & $\mathrm{U}$ & V & & 3.53 \\
\hline
\end{tabular}

Radionuclides

Actinium-228

Americium-241

Antimony-124

Antimony-125

Barium-133

Cerium-144

Cesium-134

Cesium-137

Cobalt-57

Cobalt-58

Cobalt-60

Curium-242

Curium-243/244

Curium-245/246

Europium-152

Europium-154

Europium-155

Gross alpha

Lead-212

Manganese-54

Neptunium-237

Neptunium-239

Nonvolatile beta

Potassium-40

Promethium-144

Promethium -146

Radium-226
$6.85 \mathrm{E}+00$
4.34E-02
$1.04 \mathrm{E}+00$
9.35E-01
$2.21 \mathrm{E}-01$
4.20E-02
$-3.67 \mathrm{E}-01$
$-2.21 \mathrm{E}-01$
$-5.95 \mathrm{E}-01$
2.61 E-01
$3.95 \mathrm{E}+00$
$-6.46 \mathrm{E}-03$
$3.54 \mathrm{E}-02$
$0.00 \mathrm{E}+00$
$-3.38 \mathrm{E}+00$
$-2.08 \mathrm{E}+00$
$3.36 \mathrm{E}+00$
$2.14 \mathrm{E}+01$
$5.21 \mathrm{E}+00$
$3.84 \mathrm{E}-01$
1.21E-01
$2.84 \mathrm{E}+00$
$3.77 \mathrm{E}+01$
5.77E-01
$-8.83 \mathrm{E}-01$
$-1.68 \mathrm{E}+00$
6.80E-01

EPA6010A EPA6010A EPA6010A EPA6010A EPA6010A EPA6010A EPA6010A EPA6010A EPA6010A EPA6010A EPA6010A EPA6010A EPA6010A EPA6010A EPA7470 EPA6010A EPA6010A EPA6010A EPA6010A EPA6010A EPA6010A EPA6010A EPA6010A EPA6010A
$\mathrm{pCi} / \mathrm{L} \quad 1.43 \mathrm{E}+01$ EPIA-013 $\mathrm{pCi} / \mathrm{L}$ 1.20E-01 EPIA-011 $\mathrm{pCi} / \mathrm{L} \quad 4.80 \mathrm{E}+00$ EPIA-013 $\mathrm{pCi} / \mathrm{L} \quad 1.05 \mathrm{E}+01$ EPIA-013 $\mathrm{pCi} / \mathrm{L}$ 4.78E+00 EPIA-013 $\mathrm{pCi} / \mathrm{L} \quad 2.11 \mathrm{E}+01$ EPIA-013 $\mathrm{pCi} / \mathrm{L} \quad 4.18 \mathrm{E}+00$ EPIA-013 $\mathrm{pCi} / \mathrm{L}$ 4.06E+00 EPIA-013 $\mathrm{pCi} / \mathrm{L} \quad 2.61 \mathrm{E}+00$ EPIA-013 $\mathrm{pCi} / \mathrm{L} \quad 4.10 \mathrm{E}+00$ EPIA-013 $\mathrm{pCi} / \mathrm{L}, 4.90 \mathrm{E}+00$ EPIA-013 $\mathrm{pCi} / \mathrm{L} \quad 1.09 \mathrm{E}-01$ EPIA-011 $\mathrm{pCi} / \mathrm{L}$ 1.32E-01 EPIA-011 $\mathrm{pCi} / \mathrm{L} \quad 3.06 \mathrm{E}-02$ EPIA-011 $\mathrm{pCi} / \mathrm{L} \quad 9.80 \mathrm{E}+00$ EPIA-013 $\mathrm{pCi} / \mathrm{L} \quad 1.23 \mathrm{E}+01$ EPIA-013 $\mathrm{pCi} / \mathrm{L} \quad 1.14 \mathrm{E}+01$ EPIA-013 pCi/L 4.69E+00 EPIA-001 $\mathrm{pCi} / \mathrm{L} \quad 6.23 \mathrm{E}+00$ EPIA-013 $\mathrm{pCi} / \mathrm{L} \quad 3.88 \mathrm{E}+00$ EPIA-013 $\mathrm{pCi} / \mathrm{L}, 7.30 \mathrm{E}-02$ EPIA-032 $\mathrm{pCi} / \mathrm{L} \quad 1.87 \mathrm{E}+01$ EPIA-013 $\mathrm{pCi} / \mathrm{L} \quad 4.81 \mathrm{E}+00$ EPIA-001 $\mathrm{pCi} / \mathrm{L}$ 4.42E+01 EPIA-013 $\mathrm{pCi} / \mathrm{L} \quad 3.64 \mathrm{E}+00$ EPIA-013 pCi/L 4.69E+00 EPIA-013 $\mathrm{pCi} / \mathrm{L}$ 5.01E-01 EPIA-008 
SURVEY ID: HSP 00803 (cont.)

Constituent
Radionuclides
Ruthenium-106
Sodium-22
Tin-113
Tritium
Uranium-233/234
Uranium-235
Uranium-238
Yttrium-88
Zinc-65
Zirconium-95

SURVEY ID: HSP 00803A

Sample type: Duplicate

Constituent

Specified Analyses

Chloride

Cyanide

Cyanide

Hardness as $\mathrm{CACO} 3$

Hardness as $\mathrm{CACO} 3$

Nitrate as nitrogen

Nitrate-nitrite as nitrogen

Metals (total recoverable)

Aluminum
Antimony
Arsenic
Barium
Beryllium
Cadmium
Calcium
Chromium
Cobalt
Copper
Iron
Lead
Magnesium
Manganese
Mercury
Nickel
Potassium
Selenium
Silver
Sodium
Thallium
Tin
Vanadium
Zinc

Sample ID: 114006

RQ AQ B Result Unit ssMDL Method

$\begin{array}{ll}\text { UI } & -1.35 \mathrm{E}+01 \\ \text { UI } & -7.17 \mathrm{E}-01 \\ \text { UI } & 2.76 \mathrm{E}+00 \\ & 8.90 \mathrm{E}+01 \\ & 2.18 \mathrm{E}-01 \\ \text { UI } & 1.85 \mathrm{E}-02 \\ & 1.70 \mathrm{E}-01 \\ \text { UI } & 2.48 \mathrm{E}-01 \\ \text { UI } & -1.49 \mathrm{E}+00 \\ \text { UI } & -8.69 \mathrm{E}-01\end{array}$

$\mathrm{pCi} / \mathrm{L} \quad 3.50 \mathrm{E}+01$ EPIA-013

$\mathrm{pCi} / \mathrm{L} \quad 4.42 \mathrm{E}+00$ EPIA-013

$\mathrm{pCi} / \mathrm{L} \quad 5.30 \mathrm{E}+00$ EPIA-013

pCi/mL6.06E-01 EPA906.0

$\mathrm{pCi} / 2.28 \mathrm{E}-02$ EPIA-011

$\mathrm{pCi} / \mathrm{L}$ 1.28E-01 EPIA-011

$\mathrm{pCi} / \mathrm{L}$ 7.28E-02 EPIA-011

$\mathrm{pCi} / \mathrm{L} \quad 5.91 \mathrm{E}+00$ EPIA-013

$\mathrm{pCi} / \mathrm{L} \quad 7.85 \mathrm{E}+00$ EPIA-013

$\mathrm{pCi} / \mathrm{L} \quad 7.82 \mathrm{E}+00$ EPIA-013
Sample ID: 114007

Associated sample: 114006
RQ AQ B Result Unit ssMDL Method
EPA300.0

EPA335.3

EPA335.3

EPA130.2

EPA130.2

EPA300.0

EPA353.1

\begin{tabular}{|c|c|c|c|c|c|}
\hline$J$ & L & 3400 & $\mu g / L$ & 37.6 & EPA6010A \\
\hline $\mathbf{U}$ & & 10 & $\mu \mathrm{g} / \mathrm{L}$ & 1.64 & EPA6010A \\
\hline \multirow[t]{2}{*}{ U } & & 5 & $\mu g / L$ & 2.98 & EPA6010A \\
\hline & & 13 & $\mu \mathrm{g} / \mathrm{L}$ & 0.332 & EPA6010A \\
\hline $\mathrm{U}$ & & 5 & $\mu \mathrm{g} / \mathrm{L}$ & 0.223 & EPA6010A \\
\hline \multirow[t]{2}{*}{$\mathrm{U}$} & & 5 & $\mu \mathrm{g} / \mathrm{L}$ & 0.208 & EPA6010A \\
\hline & V & 849 & $\mu \mathrm{g} / \mathrm{L}$ & 15.4 & EPA6010A \\
\hline$J$ & $\mathrm{E}$ & 1.52 & $\mu g / L$ & 0.729 & EPA6010A \\
\hline U & & 5 & $\mu g / L$ & 0.671 & EPA6010A \\
\hline \multirow[t]{2}{*}{$\mathrm{U}$} & & 5 & $\mu \mathrm{g} / \mathrm{L}$ & 1.32 & EPA6010A \\
\hline & & 1420 & $\mu \mathrm{g} / \mathrm{L}$ & 8.63 & EPA6010A \\
\hline \multirow[t]{3}{*}{$\mathrm{U}$} & & 5 & $\mu g / L$ & 0.678 & EPA6010A \\
\hline & V & 805 & $\mu \mathrm{g} / \mathrm{L}$ & 3.33 & EPA6010A \\
\hline & & 70.5 & $\mu \mathrm{g} / \mathrm{L}$ & 0.903 & EPA6010A \\
\hline$U$ & & 0.2 & $\mu \mathrm{g} / \mathrm{L}$ & 0.104 & EPA7470 \\
\hline \multirow[t]{2}{*}{$\mathrm{U}$} & & 5 & $\mu \mathrm{g} / \mathrm{L}$ & 2.27 & EPA6010A \\
\hline & & 151 & $\mu \mathrm{g} / \mathrm{L}$ & 5.87 & EPA6010A \\
\hline $\mathrm{U}$ & & 5 & $\mu \mathrm{g} / \mathrm{L}$ & 1.4 & EPA6010A \\
\hline U & & 5 & $\mu g / L$ & 0.62 & EPA6010A \\
\hline & $\mathrm{V}$ & 13300 & $\mu \mathrm{g} / \mathrm{L}$ & 29.1 & EPA6010A \\
\hline $\mathrm{U}$ & & 10 & $\mu \mathrm{g} / \mathrm{L}$ & 2.63 & EPA6010A \\
\hline $\mathrm{U}$ & & 10 & $\mu \mathrm{g} / \mathrm{L}$ & 2.94 & EPA6010A \\
\hline $\mathrm{J}$ & $\mathrm{E}$ & 4.22 & $\mu \mathrm{g} / \mathrm{L}$ & 0.427 & EPA6010A \\
\hline$U$ & $\mathrm{~V}$ & 2.01 & $\mu \mathrm{g} / \mathrm{L}$ & 0.966 & EPA6010A \\
\hline
\end{tabular}


SURVEY ID: HSP 00803A (cont.)

\section{Constituent}

Radionuclides

$\begin{array}{lll}\text { Actinium-228 } & \text { UI } & 2.37 \mathrm{E}-01 \\ \text { Antimony-124 } & \text { UI } & -1.58 \mathrm{E}+00 \\ \text { Antimony-125 } & \text { UI } & 5.09 \mathrm{E}+00 \\ \text { Barium-133 } & \text { UI } & -3.47 \mathrm{E}+00 \\ \text { Cerium-144 } & \text { UI } & -4.93 \mathrm{E}-01 \\ \text { Cesium-134 } & \text { UI } & -4.78 \mathrm{E}-01 \\ \text { Cesium-137 } & \text { UI } & 5.25 \mathrm{E}-01 \\ \text { Cobalt-57 } & \text { UI } & -1.73 \mathrm{E}+00 \\ \text { Cobalt-58 } & \text { UI } & 6.14 \mathrm{E}-02 \\ \text { Cobalt-60 } & \text { UI } & -1.96 \mathrm{E}+00 \\ \text { Europium-152 } & \text { UI } & 8.02 \mathrm{E}-01 \\ \text { Europium-154 } & \text { UI } & 1.58 \mathrm{E}+00 \\ \text { Europium-155 } & \text { UI } & 2.36 \mathrm{E}-02 \\ \text { Gross alpha } & & 6.64 \mathrm{E}+00 \\ \text { Lead-212 } & \text { R } & 1.48 \mathrm{E}+01 \\ \text { Manganese-54 } & \text { UI } & -3.08 \mathrm{E}-01 \\ \text { Neptunium-239 } & \text { UI } & -2.05 \mathrm{E}+00 \\ \text { Nonvolatile beta } & & 6.45 \mathrm{E}+00 \\ \text { Potassium-40 } & \text { UI } & 2.49 \mathrm{E}+01 \\ \text { Promethium-144 } & \text { UI } & -1.65 \mathrm{E}+00 \\ \text { Promethium-146 } & \text { UI } & 3.99 \mathrm{E}-02 \\ \text { Ruthenium-106 } & \text { UI } & 8.75 \mathrm{E}+00 \\ \text { Sodium-22 } & \text { UI } & 5.80 \mathrm{E}-01 \\ \text { Tin-113 } & \text { UI } & -4.21 \mathrm{E}+00 \\ \text { Tritium } & & 9.36 \mathrm{E}+01 \\ \text { Yttrium-88 } & \text { UI } & 1.99 \mathrm{E}+00 \\ \text { Zinc-65 } & \text { UI } & -1.14 \mathrm{E}+00 \\ \text { Zirconium-95 } & \text { UI } & -7.48 \mathrm{E}-01\end{array}$

SURVEY ID: HSP 02903
Sample ID: 114007

RQ AQ B Result

Unit ssMDL Method
$\mathrm{pCi} / \mathrm{L} \quad 2.05 \mathrm{E}+01$ EPIA-013 $\mathrm{pCi} / \mathrm{L} \quad 5.27 \mathrm{E}+00$ EPIA-013 $\mathrm{pCi} / \mathrm{L}$ 1.25E+01 EPIA-013 $\mathrm{pCi} / \mathrm{L} \quad 5.19 \mathrm{E}+00$ EPIA-013 $\mathrm{pCi} / \mathrm{L} \cdot 2.53 \mathrm{E}+01$ EPIA-013 $\mathrm{PCi} / \mathrm{L}$ 4.41E+00 EPIA-013 $\mathrm{pCi} / \mathrm{L}$ 4.75E+00 EPIA-013 pCi/ 2.98E+00 EPIA-013 $\mathrm{pCi} / \mathrm{L}$ 4.64E+00 EPIA-013 $\mathrm{pCi} / \mathrm{L}$ 4.56E+00 EPIA-013 $\mathrm{pCi} / \mathrm{L} \quad 1.23 \mathrm{E}+01$ EPIA-013 $\mathrm{pCi} / \mathrm{L}$ 1.39E+01 EPIA-013 $\mathrm{pCi} / \mathrm{L} \quad 1.37 \mathrm{E}+01$ EPIA-013 $\mathrm{pCi} / \mathrm{L}$ 5.60E-01 EPIA-001 $\mathrm{pCi} / \mathrm{L} \quad 9.00 \mathrm{E}+00$ EPIA-013 $\mathrm{pCi} / \mathrm{L} \quad 4.35 \mathrm{E}+00$ EPIA-013 pCi/L 2.36E+01 EPIA-013 $\mathrm{pCi} / \mathrm{L}$ 8.36E-01 EPIA-001 $\mathrm{pCi} / \mathrm{L} \quad 4.87 \mathrm{E}+01$ EPIA-013 $\mathrm{pCi} / \mathrm{L} \quad 4.34 \mathrm{E}+00$ EPIA-013 $\mathrm{pCi} / \mathrm{L} \quad 5.51 \mathrm{E}+00$ EPIA-013 $\mathrm{pCi} / 2 \quad 3.97 \mathrm{E}+01$ EPIA-013 $\mathrm{pCi} / \mathrm{L} \quad 4.99 \mathrm{E}+00$ EPIA-013 $\mathrm{pCi} / \mathrm{L} \quad 5.47 \mathrm{E}+00$ EPIA-013 $\mathrm{pCi} / \mathrm{mL} 5.97 \mathrm{E}-01 \quad$ EPA906.0 $\mathrm{pCi} / \mathrm{L} \quad 5.86 \mathrm{E}+00$ EPIA-013 pCi/ 9.94E+00 EPIA-013 $\mathrm{pCi} / \mathrm{L}$ 8.49E+00 EPIA-013

Survey location: $56257 \mathrm{E} 71278 \mathrm{~N}$ (SRS coordinates)

Ground elevation above MSL: . $\mathrm{ft}$

Sample type: Normal

Sample matrix: Water

\section{Constituent}

Specified Analyses
RQ AQ B Result

\begin{tabular}{|c|c|c|c|}
\hline \multirow{4}{*}{\multicolumn{2}{|c|}{ UJ }} & & 1380 \\
\hline & & $\mathbf{L}$ & 10 \\
\hline & & & 8000 \\
\hline & & & 9600 \\
\hline \multirow{2}{*}{\multicolumn{2}{|c|}{ V }} & & 994 \\
\hline & & & 1010 \\
\hline
\end{tabular}

$\begin{array}{lll} & \mathrm{V} & 10000 \\ \mathrm{U} & & 10 \\ \mathrm{U} & & 5 \\ & & 216 \\ \mathrm{~J} & \mathrm{E} & 1.78\end{array}$

Unit ssMDL Method

$\begin{array}{lll}\mu \mathrm{g} / \mathrm{L} & 7 & \mathrm{EPA300.0} \\ \mu \mathrm{g} / \mathrm{L} & 3.34 & \mathrm{EPA335.3} \\ \mu \mathrm{g} / \mathrm{L} & 1000 & \mathrm{EPA130.2} \\ \mu \mathrm{g} / \mathrm{L} & 1000 & \mathrm{EPA130.2} \\ \mu \mathrm{g} / \mathrm{L} & 6 & \mathrm{EPA300.0} \\ \mu \mathrm{g} / \mathrm{L} & 7 & \mathrm{EPA353.1}\end{array}$

$\begin{array}{lll}\mu \mathrm{g} / \mathrm{L} & 37.6 & \text { EPA6010A } \\ \mu \mathrm{g} / \mathrm{L} & 1.64 & \text { EPA6010A } \\ \mu \mathrm{g} / \mathrm{L} & 2.98 & \text { EPA6010A } \\ \mu \mathrm{g} / \mathrm{L} & 0.332 & \text { EPA6010A } \\ \mu \mathrm{g} / \mathrm{L} & 0.223 & \text { EPA6010A }\end{array}$


SURVEY ID: HSP 02903 (cont.)

Constituent

Metals (total recoverable)

Cadmium
Calcium
Chromium
Cobalt
Copper
Iron
Lead
Magnesium
Manganese
Mercury
Nickel
Potassium
Selenium
Silver
Sodium
Thallium
Tin
Vanadium
Zinc

Radionuclides

Actinium-228

Actinium-228

Americium-241

Antimony-124

Antimony-124

Antimony-125

Antimony-125

Barium-133

Barium-133

Cerium-144

Cerium-144

Cesium-134

Cesium-134

Cesium-137

Cesium-137

Cobalt-57

Cobalt -57

Cobalt-58

Cobalt-58

Cobalt -60

Cobalt-60

Curium-242

Curium-243/244

Curium-245/246

Europium-152

Europium-152

Europium-154

Europium-154

Europium-155

Europium-155

Gross alpha

Iodine-129
Sample ID: 114014

RQ AQ B Result

Unit ssMDL Method

$\begin{array}{llll}J & E & & 2.13 \\ & & 2230 \\ J & E & 4.69 \\ & & 20.7 \\ J & E & 2.75 \\ & & 2580 \\ & V & 18.7 \\ & & 1100 \\ & V & 1140 \\ U & & 0.2 \\ & & 17.8 \\ & V & 457 \\ U & & 5 \\ U & V & 3.25 \\ & V & 4490 \\ U & & 10 \\ U & & 10 \\ & & 9.07 \\ & V & 27.8\end{array}$

$\begin{array}{lll}\mu \mathrm{g} / \mathrm{L} & 0.208 & \text { EPA6010A } \\ \mu \mathrm{g} / \mathrm{L} & 15.4 & \text { EPA6010A } \\ \mu \mathrm{g} / \mathrm{L} & 0.729 & \text { EPA6010A } \\ \mu \mathrm{g} / \mathrm{L} & 0.671 & \text { EPA6010A } \\ \mu \mathrm{g} / \mathrm{L} & 1.32 & \text { EPA6010A } \\ \mu \mathrm{g} / \mathrm{L} & 8.63 & \text { EPA6010A } \\ \mu \mathrm{g} / \mathrm{L} & 0.678 & \text { EPA6010A } \\ \mu \mathrm{g} / \mathrm{L} & 3.33 & \text { EPA6010A } \\ \mu \mathrm{g} / \mathrm{L} & 0.903 & \text { EPA6010A } \\ \mu \mathrm{g} / \mathrm{L} & 0.104 & \text { EPA7470 } \\ \mu \mathrm{g} / \mathrm{L} & 2.27 & \text { EPA6010A } \\ \mu \mathrm{g} / \mathrm{L} & 5.87 & \text { EPA6010A } \\ \mu \mathrm{g} / \mathrm{L} & 1.4 & \text { EPA6010A } \\ \mu \mathrm{g} / \mathrm{L} & 0.62 & \text { EPA6010A } \\ \mu \mathrm{g} / \mathrm{L} & 29.1 & \text { EPA6010A } \\ \mu \mathrm{g} / \mathrm{L} & 2.63 & \text { EPA6010A } \\ \mu \mathrm{g} / \mathrm{L} & 2.94 & \text { EPA6010A } \\ \mu \mathrm{g} / \mathrm{L} & 0.427 & \text { EPA6010A } \\ \mu \mathrm{g} / \mathrm{L} & 0.966 & \text { EPA6010A }\end{array}$

$\mathrm{pCi} / \mathrm{L} \quad 1.94 \mathrm{E}+01$ EPIA-013

$\mathrm{pCi} / \mathrm{L} \quad 2.22 \mathrm{E}+01$ EPIA-013

$\mathrm{pCi} / \mathrm{L} \quad 6.54 \mathrm{E}-02$ EPIA-011

$\mathrm{pCi} / \mathrm{L} \quad 5.07 \mathrm{E}+00$ EPIA-013

$\mathrm{pCi} / \mathrm{L} \quad 5.90 \mathrm{E}+00$ EPIA-013

$\mathrm{pCi} / \mathrm{L} \quad 1.13 \mathrm{E}+01$ EPIA-013

$\mathrm{pCi} / \mathrm{L} 1.31 \mathrm{E}+01$ EPIA-013

$\mathrm{pCi} / \mathrm{L} \quad 5.55 \mathrm{E}+00$ EPIA-013

$\mathrm{pCi} / \mathrm{L} \quad 5.62 \mathrm{E}+00$ EPIA-013

$\mathrm{pCi} / \mathrm{L} \quad 2.91 \mathrm{E}+01$ EPIA-013

$\mathrm{pCi} / \mathrm{L} \quad 2.66 \mathrm{E}+01$ EPIA-013

$\mathrm{pCi} / \mathrm{L} \quad 4.15 \mathrm{E}+00$ EPIA-013

pCi/L 4.66E+00 EPIA-013

$\mathrm{pCi} / \mathrm{L} \quad 4.70 \mathrm{E}+00$ EPIA-013

$\mathrm{pCi} / \mathrm{L} \quad 5.26 \mathrm{E}+00$ EPIA-013

pCi $/ 2$ 3.44E +00 EPIA-013

pCi/L 3.29E+00 EPIA-013

$\mathrm{pCi} / \mathrm{L}$ 4.94E+00 EPIA-013

$\mathrm{pCi} / \mathrm{L} \quad 5.47 \mathrm{E}+00$ EPIA-013

pCi/ $5.35 \mathrm{E}+00 \cdot$ EPIA-013

$\mathrm{pCi} / \mathrm{L}$ 4.65E+00 EPIA-013

$\mathrm{pCi} / \mathrm{L} \quad 3.79 \mathrm{E}-02$ EPIA-011

рCiл 6.56E-02 EPIA-011

pCi/L 3.11E-02 EPIA-011

$\mathrm{pCi} / \mathrm{L} \quad 1.23 \mathrm{E}+01$ EPIA-013

$\mathrm{pCi} / \mathrm{L} \quad 1.28 \mathrm{E}+01$ EPIA-013

pCi/L 1.21E+01 EPIA-013

$\mathrm{pCi} / \mathrm{L}$ 1.32E+01 EPIA-013

$\mathrm{pCi} / \mathrm{L}$ 1.50E+01 EPIA-013.

$\mathrm{pCi} / \mathrm{L} \quad 1.45 \mathrm{E}+01$ EPIA-013

$\mathrm{pCi} / \mathrm{L}$ 5.62E-01 EPIA-001

$\mathrm{pCi} /$ 9.10E-01 EPIA-006

Data Summary Report for the Annual Fourmile Branch and 
SURVEY ID: HSP 02903 (cont.)

Constituent

Radionuclides

$\begin{array}{lll}\text { Iodine-129 } & \text { UIJ C } & 1.54 \mathrm{E}+00 \\ \text { Lead-212 } & \text { UI } & 5.42 \mathrm{E}+00 \\ \text { Lead-212 } & \text { UI } & 3.75 \mathrm{E}+00 \\ \text { Manganese-54 } & \text { UI } & -5.93 \mathrm{E}-01 \\ \text { Manganese-54 } & \text { UI } & 2.44 \mathrm{E}-01 \\ \text { Neptunium-237 } & \text { UI } & 3.22 \mathrm{E}-01 \\ \text { Neptunium-239 } & \text { UI } & -6.40 \mathrm{E}+00 \\ \text { Neptunium-239 } & \text { UI } & -1.71 \mathrm{E}+01 \\ \text { Nickel-63 } & \text { UI } & 4.07 \mathrm{E}+01 \\ \text { Nickel-63 } & & 1.96 \mathrm{E}+02 \\ \text { Nonvolatile beta } & \text { UI } & 3.32 \mathrm{E}+02 \\ \text { Potassium-40 } & \text { UI } & 4.66 \mathrm{E}+01 \\ \text { Potassium-40 } & \text { UI } & 4.53 \mathrm{E}+01 \\ \text { Promethium-144 } & \text { UI } & 1.03 \mathrm{E}+00 \\ \text { Promethium-144 } & \text { UI } & 2.07 \mathrm{E}+00 \\ \text { Promethium-146 } & \text { UI } & 4.30 \mathrm{E}-01 \\ \text { Promethium-146 } & & -1.73 \mathrm{E}+00 \\ \text { Radium-226 } & & 7.91 \mathrm{E}+00 \\ \text { Radium-226 } & \text { UI } & 7.29 \mathrm{E}+00 \\ \text { Radium-228 } & \text { UI } & -2.50 \mathrm{E}-02 \\ \text { Radium-228 } & \text { UI } & -1.52 \mathrm{E}+01 \\ \text { Ruthenium-106 } & \text { UI } & 7.08 \mathrm{E}+00 \\ \text { Ruthenium-106 } & \text { UI } & -8.02 \mathrm{E}-01 \\ \text { Sodium-22 } & \text { UI } & -9.55 \mathrm{E}-01 \\ \text { Sodium-22 } & \text { UI } & -2.99 \mathrm{E}+00 \\ \text { Tin-113 } & \text { UI } & 2.06 \mathrm{E}+00 \\ \text { Tin-113 } & & 2.66 \mathrm{E}+01 \\ \text { Tritium } & & 5.34 \mathrm{E}-01 \\ \text { Uranium-233/234 } & \text { UI } & 1.97 \mathrm{E}-01 \\ \text { Uranium-235 } & \text { UI } & 4.01 \mathrm{E}-02 \\ \text { Uranium-238 } & \text { UI } & -1.71 \mathrm{E}+00 \\ \text { Yttrium-88 } & \text { UI } & 3.17 \mathrm{E}-01 \\ \text { Yttrium-88 } & \text { UI } & -2.10 \mathrm{E}+00 \\ \text { Zinc-65 } & \text { UI } & -3.92 \mathrm{E}+00 \\ \text { Zinc-65 } & \text { UI } & 3.43 \mathrm{E}+00 \\ \text { Zirconium-95 } & -3.87 \mathrm{E}+00 \\ \text { Zirconium-95 } & & \end{array}$

Unit ssMDL Method

$\mathrm{pCi} / \mathrm{L} \quad 7.59 \mathrm{E}-01$ EPIA-006 pCi/L 9.10E+00 EPIA-013 $\mathrm{pCi} / \mathrm{L} \quad$ 8.71E+00 EPIA-013 $\mathrm{pCi} / \mathrm{L} \quad 4.80 \mathrm{E}+00$ EPIA-013 $\mathrm{pCi} / \mathrm{L} \quad 5.47 \mathrm{E}+00$ EPIA-013 pCi/L 1.28E-01 EPIA-032 $\mathrm{pCi} / \mathrm{L} 2.66 \mathrm{E}+01$ EPIA-013 $\mathrm{pCi} / \mathrm{L} \quad 2.33 \mathrm{E}+01$ EPIA-013 $\mathrm{pCi} / \mathrm{L} \quad 2.49 \mathrm{E}+02$ EPIA-022 $\mathrm{pCi} / \mathrm{L} \quad 2.55 \mathrm{E}+02$ EPIA-022 $\mathrm{pCi} / \mathrm{L}$ 9.36E-01 EPIA-001 $\mathrm{pCi} / \mathrm{L} \quad 4.64 \mathrm{E}+01$ EPIA.013 pCi/L 6.88E+01 EPIA-013 $\mathrm{pCi} / \mathrm{L} \quad 4.75 \mathrm{E}+00$ EPIA-013 $\mathrm{pCi} / \mathrm{L} \quad 4.93 \mathrm{E}+00$ EPIA-013 $\mathrm{pCi} / \mathrm{L} \quad 5.63 \mathrm{E}+00$ EPIA-013 pCi $/ 2$ 5.67E+00 EPIA-013 $\mathrm{pCi} / \mathrm{L}$ 7.07E-01 EPIA-008 pCi/L 5.48E-01 EPIA-008 $\mathrm{pCi} / \mathrm{L}$ 7.11E-01 EPIA-009 $\mathrm{pCi} / \mathrm{L} \quad 7.83 \mathrm{E}-01$ EPIA-009 $\mathrm{pCi} / \mathrm{L} \quad 3.66 \mathrm{E}+01$ EPIA-013 pCi/L 4.53E+01 EPIA-013 $\mathrm{pCi} / \mathrm{L}$ 4.32E+00 EPIA-013 $\mathrm{pCi} / \mathrm{L} \quad 4.75 \mathrm{E}+00$ EPIA-013 $\mathrm{pCi} / \mathrm{L} \quad 5.17 \mathrm{E}+00$ EPIA-013 $\mathrm{pCi} / \mathrm{L} \quad 6.61 \mathrm{E}+00$ EPIA-013 $\mathrm{pCi} / \mathrm{mL} 5.88 \mathrm{E}-01 \quad$ EPA906.0 $\mathrm{pCi} / \mathrm{L} \quad 2.37 \mathrm{E}-01$ EPIA-011 $\mathrm{pCi} / \mathrm{L}$ 2.18E-01 EPIA-011 $\mathrm{pCi} / \mathrm{L} \quad 2.18 \mathrm{E}-01$ EPIA-011 $\mathrm{pCi} / \mathrm{L} \quad 4.74 \mathrm{E}+00$ EPIA-013 $\mathrm{pCi} / \mathrm{L} \quad 6.60 \mathrm{E}+00$ EPIA-013 $\mathrm{pCi} / \mathrm{L} \quad 1.10 \mathrm{E}+01$ EPIA-013 $\mathrm{pCi} / \mathrm{L} \quad 1.11 \mathrm{E}+01$ EPIA-013 $\mathrm{pCi} / \mathrm{L}$ 8.73E+00 EPIA-013 $\mathrm{pCi} / \mathrm{L} \quad 9.79 \mathrm{E}+00$ EPIA-013

SURVEY ID: HSP 04303

Sample ID: 114015

Survey location: 55722E 71644N (SRS coordinates)

Ground elevation above MSL: . $\mathrm{ft}$

Sample type: Normal

Constituent

Specified Analyses

Chloride

Cyanide

Hardness as $\mathrm{CACO} 3$

Nitrate as nitrogen
Sample matrix: Water

RQ AQ B Result Unit ssMDL Method

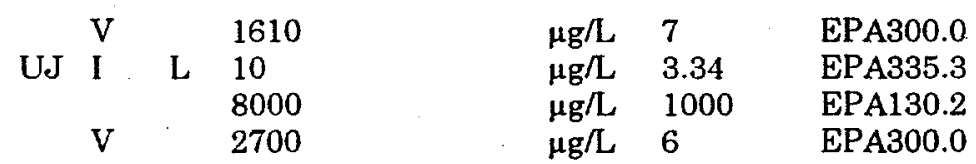


SURVEY ID: HSP 04303 (cont.)

\section{Constituent}

Specified Analyses

Nitrate-nitrite as nitrogen

Metals (total recoverable)

Aluminum
Antimony
Arsenic
Barium
Beryllium
Cadmium
Calcium
Chromium
Cobalt
Copper
Iron
Lead
Magnesium
Manganese
Mercury
Nickel
Potassium
Selenium
Silver
Sodium
Thallium
Tin
Vanadium
Zinc

Radionuclides

Actinium-228

Antimony-124

Antimony-125

Barium-133

Cerium-144

Cesium-134

Cesium-137

Cobalt -57

Cobalt-58

Cobalt-60

Europium-152

Europium-154

Europium-155

Gross alpha

Iodine-129

Lead-212

Manganese-54

Neptunium-239

Nickel-63

Nonvolatile beta

Potassium -40

Promethium-144

Promethium-146
Sample ID: 114015

RQ AQ B Result

Unit ssMDL Method

2480

$\mu \mathrm{g} / \mathrm{L} \quad 7$

EPA353.1

$\begin{array}{lll}\mu \mathrm{g} / \mathrm{L} & 37.6 & \text { EPA6010A } \\ \mu \mathrm{g} / \mathrm{L} & 1.64 & \text { EPA6010A } \\ \mu \mathrm{g} / \mathrm{L} & 2.98 & \text { EPA6010A } \\ \mu \mathrm{g} / \mathrm{L} & 0.332 & \text { EPA6010A } \\ \mu \mathrm{g} / \mathrm{L} & 0.223 & \text { EPA6010A } \\ \mu \mathrm{g} / \mathrm{L} & 0.208 & \text { EPA6010A } \\ \mu \mathrm{g} / \mathrm{L} & 15.4 & \text { EPA6010A } \\ \mu \mathrm{g} / \mathrm{L} & 0.729 & \text { EPA6010A } \\ \mu \mathrm{g} / \mathrm{L} & 0.671 & \text { EPA6010A } \\ \mu \mathrm{g} / \mathrm{L} & 1.32 & \text { EPA6010A } \\ \mu \mathrm{g} / \mathrm{L} & 8.63 & \text { EPA6010A } \\ \mu \mathrm{g} / \mathrm{L} & 0.678 & \text { EPA6010A } \\ \mu \mathrm{g} / \mathrm{L} & 3.33 & \text { EPA6010A } \\ \mu \mathrm{g} / \mathrm{L} & 0.903 & \text { EPA6010A } \\ \mu \mathrm{g} / \mathrm{L} & 0.104 & \text { EPA7470 } \\ \mu \mathrm{g} / \mathrm{L} & 2.27 & \text { EPA6010A } \\ \mu \mathrm{g} / \mathrm{L} & 5.87 & \text { EPA6010A } \\ \mu \mathrm{g} / \mathrm{L} & 1.4 & \text { EPA6010A } \\ \mu \mathrm{g} / \mathrm{L} & 0.62 & \text { EPA6010A } \\ \mu \mathrm{g} / \mathrm{L} & 29.1 & \text { EPA6010A } \\ \mu \mathrm{g} / \mathrm{L} & 2.63 & \text { EPA6010A } \\ \mu \mathrm{g} / \mathrm{L} & 2.94 & \text { EPA6010A } \\ \mu \mathrm{g} / \mathrm{L} & 0.427 & \text { EPA6010A } \\ \mu \mathrm{g} / \mathrm{L} & 0.966 & \text { EPA6010A } \\ & & \end{array}$

$\mathrm{pCi} / \mathrm{L} \quad 1.77 \mathrm{E}+01$ EPIA-013

$\mathrm{pCi} / \mathrm{L} 4.95 \mathrm{E}+00$ EPIA-013

$\mathrm{pCi} / \mathrm{L} \quad 1.02 \mathrm{E}+01$ EPIA-013

$\mathrm{pCi} / 2 \quad 4.79 \mathrm{E}+00$ EPIA-013

$\mathrm{pCi} / \mathrm{L} \quad 2.22 \mathrm{E}+01$ EPIA-013

$\mathrm{pCi} / \mathrm{L} \quad 3.91 \mathrm{E}+00$ EPIA-013

$\mathrm{pCi} / \mathrm{L} \quad 4.07 \mathrm{E}+00$ EPIA-013

$\mathrm{pCi} / \mathrm{L} \quad 2.65 \mathrm{E}+00$ EPIA-013

$\mathrm{pCi} / \mathrm{L} \quad 3.90 \mathrm{E}+00$ EPIA-013

pCi/L 4.32E+00 EPIA-013

pCi/L 1.07E+01 EPIA-013

$\mathrm{pCi} / \mathrm{L} \quad 1.22 \mathrm{E}+01$ EPIA-013

$\mathrm{pCi} / \mathrm{L}$ 1.12E+01 EPIA-013

pCi/L 8.11E-01 EPIA-001

pCi/L 6.30E-01 EPIA-006

pCi/L 7.89E+00 EPIA-013

$\mathrm{pCi} / \mathrm{L}$ 4.03E+00 EPIA-013

$\mathrm{pCi} / \mathrm{L} \quad 1.97 \mathrm{E}+01$ EPIA-013

$\mathrm{pCi} / \mathrm{L} 2.33 \mathrm{E}+02$ EPIA-022

$\mathrm{pCi} / \mathrm{L} \quad 1.25 \mathrm{E}+00$ EPIA-001

$\mathrm{pCi} / \mathrm{L}$ 5.90E+01 EPIA-013

$\mathrm{pCi} / \mathrm{L} \quad 4.28 \mathrm{E}+00$ EPIA-013

$\mathrm{pCi} / \mathrm{L} \quad 4.98 \mathrm{E}+00$ EPIA-013

Data Summary Report for the Annual Fourmile Branch and

F- and H-Area Seeplines, Appendix IX Metals and Radionuclides, 1998

(WSRC-TR-98-00260) 
SURVEY ID: HSP 04303 (cont.)

Constituent

Radionuclides

Radium-228

Ruthenium-106

Sodium-22

Tin-113.

Tritium

Yttrium-88

Zinc-65

Zirconium-95
Sample ID: 114015

RQ AQ B Result Unit ssMDL Method
SURVEY ID: HSP 06003

Survey location: 55190E 71629N (SRS coordinates)

Ground elevation above MSL: . ft

Sample type: Normal

Constituent

Specified Analyses

Chloride

Chloride

Cyanide

Hardness as $\mathrm{CACO} 3$

Nitrate as nitrogen

Nitrate as nitrogen

Nitrate-nitrite as nitrogen

Metals (total recoverable)

Aluminum

Antimony

Arsenic

Barium

Beryllium

Cadmium

Calcium

Chromium

Cobalt

Copper

Iron

Lead

Magnesium

Manganese

Mercury

Nickel

Potassium

Selenium

Silver

Sodium

Thallium

Tin

Vanadium

Zinc

$\begin{array}{ll}\text { UI } & 2.34 \mathrm{E}-01 \\ \text { UI } & -5.92 \mathrm{E}+00 \\ \text { UI } & -4.21 \mathrm{E}-01 \\ \text { UI } & -1.26 \mathrm{E}+00 \\ & 1.72 \mathrm{E}+03 \\ \text { UI } & -1.77 \mathrm{E}+00 \\ \text { UI } & -1.97 \mathrm{E}+00 \\ \text { UI } & -9.78 \mathrm{E}-01\end{array}$

Sample ID: 114012
$\mathrm{pCi} / \mathrm{L} \quad 6.74 \mathrm{E}-01 \quad$ EPIA-009

$\mathrm{pCi} / \mathrm{L} \quad 3.54 \mathrm{E}+01$ EPIA-013

$\mathrm{pCi} / \mathrm{L} \quad 4.37 \mathrm{E}+00$ EPIA-013

pCi/L 4.77E+00 EPIA-013

pCi/mL3.07E+00 EPA906.0

pCi/L 5.16E+00 EPIA-013

$\mathrm{pCi} / \mathrm{L} \quad 8.81 \mathrm{E}+00$ EPIA-013

$\mathrm{pCi} / \mathrm{L} \quad 7.88 \mathrm{E}+00$ EPIA-013
Sample matrix: Water

RQ AQ B Result

Unit ssMDL Method

$\begin{array}{lll}\mu \mathrm{g} / \mathrm{L} & 7 & \text { EPA300.0 } \\ \mu \mathrm{g} / \mathrm{L} & 7 & \text { EPA300.0 } \\ \mu \mathrm{g} / \mathrm{L} & 3.34 & \text { EPA335.3 } \\ \mu \mathrm{g} / \mathrm{L} & 1000 & \text { EPA130.2 } \\ \mu \mathrm{g} / \mathrm{L} & 6 & \text { EPA300.0 } \\ \mu \mathrm{g} / \mathrm{L} & 6 & \text { EPA300.0 } \\ \mu \mathrm{g} / \mathrm{L} & 7 & \text { EPA353.1 }\end{array}$

$\mu \mathrm{g} / \mathrm{L} \quad 37.6$

EPA6010A

$\mu \mathrm{g} / \mathrm{L} \quad 1.64 \quad$ EPA6010A

$\mu \mathrm{g} / \mathrm{L} \quad 2.98 \quad$ EPA6010A

$\mu \mathrm{g} / \mathrm{L} \quad 0.332 \quad$ EPA6010A

$\mu \mathrm{g} / \mathrm{L} \quad 0.223 \quad$ EPA6010A

$\mu \mathrm{g} / \mathrm{L} \quad 0.208 \quad$ EPA6010A

$\mu \mathrm{g} / \mathrm{L} \quad 15.4 \quad$ EPA6010A

$\mu \mathrm{g} / \mathrm{L} \quad 0.729 \quad$ EPA6010A

$\mu \mathrm{g} / \mathrm{L} \quad 0.671 \quad$ EPA6010A

$\mu \mathrm{g} / \mathrm{L} \quad 1.32 \quad$ EPA6010A

$\mu \mathrm{g} / \mathrm{L} \quad 8.63 \quad$ EPA6010A

$\mu \mathrm{g} / \quad 0.678 \quad$ EPA6010A

$\mu \mathrm{g} / \mathrm{L} \quad 3.33 \quad$ EPA6010A

$\mu \mathrm{g} / \mathrm{L} \quad 0.903 \quad$ EPA6010A

$\mu \mathrm{g} / \mathrm{L} \quad 0.104 \quad \mathrm{EPA7470}$

$\mu \mathrm{g} / \mathrm{L} \quad 2.27 \quad$ EPA6010A

$\mu \mathrm{g} / \mathrm{L} \quad \mathbf{5 . 8 7} \quad$ EPA6010A

$\mu \mathrm{g} / \mathrm{L} \quad 1.4 \quad$ EPA6010A

$\mu \mathrm{g} / \mathrm{L} \quad 0.62 \quad$ EPA6010A

$\mu \mathrm{g} / \mathrm{L} \quad 29.1 \quad$ EPA6010A

$\mu \mathrm{g} / \mathrm{L} \quad 2.63 \quad$ EPA6010A

$\mu \mathrm{g} / \mathrm{L} \quad 2.94 \quad$ EPA6010A

$\mu \mathrm{g} / \mathrm{L} \quad 0.427 \quad$ EPA6010A

$\mu \mathrm{g} / \mathrm{L} \quad 0.966 \quad$ EPA6010A 
SURVEY ID: HSP 06003 (cont.)

Constituent

Radionuclides

\begin{tabular}{lr} 
Actinium-228 & UI \\
Antimony-124 & UI \\
Antimony-125 & UI \\
Barium-133 & UI \\
Cerium-144 & UI \\
Cesium-134 & UI \\
Cesium-137 & UI \\
Cobalt-57 & UI \\
Cobalt-58 & UI \\
Cobalt-60 & UI \\
Europium-152 & UI \\
Europium-154 & UI \\
Europium-155 & UI \\
Gross alpha & \\
Lead-212 & UI \\
Manganese-54 & UI \\
Neptunium-239 & UI \\
Nonvolatile beta & \\
Potassium-40 & UI \\
Promethium-144 & UI \\
Promethium-146 & UI \\
Ruthenium-106 & UI \\
Sodium-22 & UI \\
Tin-113 & UI \\
Tritium & \\
Yttrium-88 & UI \\
Zinc-65 & UI \\
Zirconium-95 & UI \\
\hline
\end{tabular}

SURVEY ID: HSP 06003D

Sample type: Split

Constituent

Specified Analyses

Chloride

Cyanide

Cyanide

Hardness as $\mathrm{CACO} 3$

Nitrate as nitrogen

Nitrate-nitrite as nitrogen

Metals (total recoverable)

Aluminum

Antimony

Arsenic

Barium

Beryllium

Cadmium

Calcium
Sample ID: 114012

RQ AQ B Result

Unit ssMDL Method
$\mathrm{pCi} / \mathrm{L} \quad 2.45 \mathrm{E}+01$ EPIA-013 $\mathrm{pCi} / \mathrm{L}$ 6.15E+00 EPIA-013 $\mathrm{pCi} / \mathrm{L} \quad 1.38 \mathrm{E}+01$ EPIA-013

$\mathrm{pCi} / \mathrm{L}$ 6.42E+00 EPIA-013 $\mathrm{pCi} / \mathrm{L} \quad 2.97 \mathrm{E}+01$ EPIA-013 $\mathrm{pCi} / \mathrm{L}$ 5.02E+00 EPIA-013 $\mathrm{pCi} / \mathrm{L} \quad 6.20 \mathrm{E}+00$ EPIA-013 $\mathrm{pCi} / \mathrm{L} \quad 3.41 \mathrm{E}+00$ EPIA-013 $\mathrm{pCi} / \mathrm{L}$ 6.17E+00 EPIA-013 $\mathrm{pCi} / \mathrm{L}$ 6.24E+00 EPIA-013 $\mathrm{pCi} / \mathrm{L} \quad 1.47 \mathrm{E}+01$ EPIA-013 $\mathrm{pCi} / \mathrm{L} \quad 1.65 \mathrm{E}+01$ EPIA-013 $\mathrm{pCi} / \mathrm{L} \quad 1.49 \mathrm{E}+01$ EPIA-013 $\mathrm{pCi} / \mathrm{L} \quad 1.71 \mathrm{E}+00$ EPIA-001 $\mathrm{pCi} / \mathrm{L}$ 9.59E+00 EPIA-013 $\mathrm{pCi} / \mathrm{L} \quad 5.83 \mathrm{E}+00$ EPIA-013 $\mathrm{pCi} / \mathrm{L} \quad 2.67 \mathrm{E}+01$ EPIA-013 $\mathrm{pCi} / \mathrm{L} \quad 2.13 \mathrm{E}+00$ EPIA-001 $\mathrm{pCi} / \mathrm{L} \quad 8.45 \mathrm{E}+01$ EPIA-013 $\mathrm{pCi} / \mathrm{L} \quad 5.34 \mathrm{E}+00$ EPIA-013 pCi/L 6.19E+00 EPIA-013 $\mathrm{pCi} / \mathrm{L} \quad 5.02 \mathrm{E}+01$ EPIA-013 $\mathrm{pCi} / \mathrm{L} \quad 5.92 \mathrm{E}+00$ EPIA-013 $\mathrm{pCi} / \mathrm{L} \quad 6.34 \mathrm{E}+00$ EPIA-013 $\mathrm{pCi} / \mathrm{mL} 1.05 \mathrm{E}+00$ EPA906.0 $\mathrm{pCi} / \mathrm{L} \quad 7.29 \mathrm{E}+00$ EPIA-013 $\mathrm{pCi} / \mathrm{L} \quad 1.15 \mathrm{E}+01$ EPIA-013 $\mathrm{pCi} / \mathrm{L} \quad 9.59 \mathrm{E}+00$ EPIA-013

Sample ID: 114013

Associated sample: 114012

RQ AQ B Result

$\begin{array}{lll} & & 2570 \\ U & & 30.4 \\ U & & 30.4 \\ & & 11000 \\ J & Q & 143 \\ J & E & 31\end{array}$

$\begin{array}{lll} & & 8200 \\ \mathrm{U} & & 27 \\ \mathrm{U} & & 40 \\ & \mathrm{~V} & 20.6 \\ \mathrm{U} & & 1.6 \\ \mathrm{U} & & 4.7 \\ & & 958\end{array}$

Unit ssMDL Method

$\mu \mathrm{g} / \mathrm{L} \quad 21$

EPA9056

$\mu \mathrm{g} / \mathrm{L} \quad 3.04$

$\mu \mathrm{g} / \mathrm{L} \quad 3.04$

$\mu \mathrm{g} / \mathrm{L} \quad 900$

$\mu_{\mathrm{g}} / \mathrm{L} \quad 2$

$\mu \mathrm{g} / \mathrm{L} \quad 4$

EPA9010A

EPA9010A

EPA130.2

EPA353.2

EPA353.2

$\begin{array}{lll}\mu \mathrm{g} / \mathrm{L} & 14.6 & \text { EPA6010 } \\ \mu \mathrm{g} / \mathrm{L} & 2.7 & \text { EPA6010 } \\ \mu \mathrm{g} / \mathrm{L} & 4 & \text { EPA6010 } \\ \mu \mathrm{g} / \mathrm{L} & 0.18 & \text { EPA6010 } \\ \mu \mathrm{g} / \mathrm{L} & 0.16 & \text { EPA6010 } \\ \mu \mathrm{g} / \mathrm{L} & 0.47 & \text { EPA6010 } \\ \mu \mathrm{g} / \mathrm{L} & 47.1 & \text { EPA6010 }\end{array}$


SURVEY ID: HSP 06003D (cont.)

Constituent

Metals (total recoverable)

Chromium

Cobalt

Copper

Iron

Lead

Magnesium

Manganese

Mercury

Mercury

Nickel

Potassium

Selenium

Silver

Sodium

Thallium

Tin

Vanadium

Zinc

\section{Radionuclides}

Actinium-228

Actinium-228

Antimony-124

Antimony-124

Antimony-125

Antimony-125

Barium-133

Barium-133

Cerium-144

Cerium-144

Cesium-134

Cesium-134

Cesium-137

Cesium-137

Cobalt-57

Cobalt-57

Cobalt-58

Cobalt-58

Cobalt-60

Cobalt-60

Europium-152

Europium-152

Europium-154

Europium-154

Europium-155

Europium-155

Gross alpha

Gross alpha

Lead-212

Lead-212

Manganese-54

Manganese-54

Nonvolatile beta
Sample ID: 114013

RQ AQ B Result

Unit ssMDL Method

$\begin{array}{lll}\mu \mathrm{g} / \mathrm{L} & 0.7 & \text { EPA6010 } \\ \mu \mathrm{g} / \mathrm{L} & 0.45 & \text { EPA6010 } \\ \mu \mathrm{g} / \mathrm{L} & 1.5 & \text { EPA6010 } \\ \mu \mathrm{g} / \mathrm{L} & 7.4 & \text { EPA6010 } \\ \mu \mathrm{g} / \mathrm{L} & 4.7 & \text { EPA6010 } \\ \mu \mathrm{g} / \mathrm{L} & 7.4 & \text { EPA6010 } \\ \mu \mathrm{g} / \mathrm{L} & 0.78 & \text { EPA6010 } \\ \mu \mathrm{g} / \mathrm{L} & 0.07 & \text { EPA7470 } \\ \mu \mathrm{g} / \mathrm{L} & 0.07 & \text { EPA7470 } \\ \mu \mathrm{g} / \mathrm{L} & 2.6 & \text { EPA6010 } \\ \mu \mathrm{g} / \mathrm{L} & 18.7 & \text { EPA6010 } \\ \mu \mathrm{g} / \mathrm{L} & 6.6 & \text { EPA6010 } \\ \mu \mathrm{g} / \mathrm{L} & 0.5 & \text { EPA6010 } \\ \mu \mathrm{g} / \mathrm{L} & 28.5 & \text { EPA6010 } \\ \mu \mathrm{g} / \mathrm{L} & 5.5 & \text { EPA6010 } \\ \mu \mathrm{g} / \mathrm{L} & 7 & \text { EPA6010 } \\ \mu \mathrm{g} / \mathrm{L} & 0.69 & \text { EPA6010 } \\ \mu \mathrm{g} / \mathrm{L} & 5.3 & \text { EPA6010 }\end{array}$

$\mathrm{pCi} / \mathrm{L} \quad 1.57 \mathrm{E}+01$ EPA901.1MOD

$\mathrm{pCi} / \mathrm{L} \quad 1.51 \mathrm{E}+01$ EPA901.1MOD

$\mathrm{pCi} / \mathrm{L}$ 5.40E+00 EPA901.1MOD

$\mathrm{pCi} / \mathrm{L}$ 5.10E+00 EPA901.1MOD

$\mathrm{pCi} / \mathrm{L}$ 8.43E+00 EPA901.1MOD

$\mathrm{pCi} / \mathrm{L}$ 9.14E+00 EPA901.1MOD

$\mathrm{pCi} / \mathrm{L} \quad 3.94 \mathrm{E}+00$ EPA901.1MOD

$\mathrm{pCi} / \mathrm{L}$ 4.00E+00 EPA901.1MOD

$\mathrm{pCi} / \mathrm{L}$ 1.68E+01 EPA901.1MOD

$\mathrm{pCi} / \mathrm{L}$ 1.72E+01 EPA901.1MOD

$\mathrm{pCi} / \mathrm{L} \quad 3.94 \mathrm{E}+00$ EPA901.1MOD

$\mathrm{pCi} / \mathrm{L}$ 3.73E+00 EPA901.1MOD

$\mathrm{pCi} / \mathrm{L}$ 4.08E+00 EPA901.1MOD

$\mathrm{pCi} / \mathrm{L}$ 4.06E+00 EPA901.1MOD

$\mathrm{pCi} / \mathrm{L}$ 2.14E+00 EPA901.1MOD

$\mathrm{pCi} / \mathrm{L}$ 2.03E+00 EPA901.1MOD

$\mathrm{pCi} / \mathrm{L}$ 4.63E+00 EPA901.1MOD

$\mathrm{pCi} / \mathrm{L} \quad 5.01 \mathrm{E}+00$ EPA901.1MOD

$\mathrm{pCi} / \mathrm{L}$ 3.45E+00 EPA901.1MOD

$\mathrm{pCi} / \mathrm{L}$ 4.03E+00 EPA901.1MOD

$\mathrm{pCi} / \mathrm{L}$ 2.15E+01 EPA901.1MOD

pCi/L 3.56E+01 EPA901.1MOD

$\mathrm{pCi} / \mathrm{L} \quad 1.40 \mathrm{E}+01$ EPA901.1MOD

$\mathrm{pCi} / \mathrm{L}$ 1.21E+01 EPA901.1MOD

$\mathrm{pCi} / \mathrm{L}$ 5.71E+00 EPA901.1MOD

$\mathrm{pCi} / \mathrm{L}$ 5.79E+00 EPA901.1MOD

$\mathrm{pCi} / \mathrm{L} \quad$ 1.33E+00 EPA900.0MOD

$\mathrm{pCi} / \mathrm{L} \quad 1.51 \mathrm{E}+00$ EPA900.0MOD

$\mathrm{pCi} / \mathrm{L}$ 5.11E+00 EPA901.1MOD

$\mathrm{pCi} / \mathrm{L}$ 4.72E+00 EPA901.1MOD

$\mathrm{pCi} / \mathrm{L}$ 4.41E+00 EPA901.1MOD

$\mathrm{pCi} / \mathrm{L}$ 4.08E+00 EPA901.1MOD

$\mathrm{pCi} / \mathrm{L} \quad 1.88 \mathrm{E}+00$ EPA900.0MOD

Data Summary Report for the Annual Fourmile Branch and

F- and H-Area Seeplines, Appendix IX Metals and Radionuclides, 1998

(WSRC-TR-98-00260) 
SURVEY ID: HSP 06003D (cont.)

Constituent

Radionuclides

Nonvolatile beta

Potassium -40

Potassium -40

Promethium-144

Promethium-144

Promethium-146

Promethium-146

Ruthenium-106

Ruthenium-106

Sodium-22

Sodium-22

Tin-113

Tin-113

Tritium

Tritium

Yttrium-88

Yttrium-88

Zinc-65

Zinc-65

Zirconium-95

Zirconium-95
Sample ID: 114013

RQ AQ B Result

Unit ssMDL Method

$\mathrm{pCi} / \mathrm{L} \quad$ 1.92E+00 EPA900.0MOD $\mathrm{pCi} / \mathrm{L} \quad 3.94 \mathrm{E}+01$ EPA901.1MOD $\mathrm{pCi} / \mathrm{L} \quad 3.44 \mathrm{E}+01$ EPA901.1MOD $\mathrm{pCi} / \mathrm{L} \quad 3.83 \mathrm{E}+00$ EPA901.1MOD pCi/L 4.17E+00 EPA901.1MOD $\mathrm{pCi} / \mathrm{L}$ 6.28E+00 EPA901.1MOD $\mathrm{pCi} / \mathrm{L} \quad 6.50 \mathrm{E}+00$ EPA901.1MOD $\mathrm{pCi} / \mathrm{L} \quad 3.49 \mathrm{E}+01$ EPA901.1MOD $\mathrm{pCi} / \mathrm{L} \quad 3.29 \mathrm{E}+01$ EPA901.1MOD $\mathrm{pCi} / \mathrm{L}$ 5.08E+00 EPA901.1MOD $\mathrm{pCi} / \mathrm{L}$ 4.38E+00 EPA901.1MOD $\mathrm{pCi} / \mathrm{L}$ 4.55E+00 EPA901.1MOD $\mathrm{pCi} / \mathrm{L}$ 4.90E+00 EPA901.1MOD pCi/mL5.80E-01 EPA906.0MOD $\mathrm{pCi} / \mathrm{mL} 6.80 \mathrm{E}-01$ EPA906.0MOD $\mathrm{pCi} / \mathrm{L}$ 4.75E+00 EPA901.1MOD $\mathrm{pCi} / \mathrm{L}$ 4.72E+00 EPA901.1MOD $\mathrm{pCi} / \mathrm{L}$ 7.45E+00 EPA901.1MOD $\mathrm{pCi} / \mathrm{L} \quad 8.18 \mathrm{E}+00$ EPA901.1MOD $\mathrm{pCi} / \mathrm{L}$ 1.01E+01 EPA901.1MOD $\mathrm{pCi} / \mathrm{L}$ 8.72E +00 EPA901.1MOD

SURVEY ID: HSP 09203

Sample ID: 114011

Survey location: $54129 \mathrm{E} 72672 \mathrm{~N}$ (SRS coordinates)

Ground elevation above MSL: . ft

Sample type: Normal

Sample matrix: Water

Constituent

RQ AQ B Result

Unit ssMDL Method

Specified Analyses

Chloride

Cyanide

Hardness as $\mathrm{CACO} 3$

Nitrate as nitrogen

Nitrate-nitrite as nitrogen

Nitrate-nitrite as nitrogen

$\begin{array}{clll} & \text { V } & & 1980 \\ \text { UJ I } & \text { L } & 10 \\ & & 8000 \\ & & 1190 \\ \text { V } & & 1180 \\ & & 1170\end{array}$

$\begin{array}{ll}\mu \mathrm{g} / \mathrm{L} & 7 \\ \mu \mathrm{g} / \mathrm{L} & 3.34 \\ \mu \mathrm{g} / \mathrm{L} & 1000 \\ \mu \mathrm{g} / \mathrm{L} & 6 \\ \mu \mathrm{g} / \mathrm{L} & 7 \\ \mu \mathrm{g} / \mathrm{L} & 7\end{array}$

EPA300.0

EPA335.3

EPA130.2

EPA300.0

EPA353.1

EPA353.1

Metals (total recoverable)

Aluminum
Antimony
Arsenic
Barium
Beryllium
Cadmium
Calcium
Chromium
Cobalt
Copper
Iron
Lead

$\begin{array}{lll} & \mathrm{V} & 3330 \\ \mathrm{U} & & 10 \\ \mathrm{U} & & 5 \\ & & 51.1 \\ \mathrm{U} & & 5 \\ \mathrm{U} & & 5 \\ & & 584 \\ \mathrm{~J} & \mathrm{E} & 1.92 \\ \mathrm{U} & & 5 \\ \mathrm{U} & & 5 \\ & & 1330 \\ \mathrm{U} & \mathrm{V} & 3.18\end{array}$

$\begin{array}{lll}\mu \mathrm{g} / \mathrm{L} & 37.6 & \text { EPA6010A } \\ \mu \mathrm{g} / \mathrm{L} & 1.64 & \text { EPA6010A } \\ \mu \mathrm{g} / \mathrm{L} & 2.98 & \text { EPA6010A } \\ \mu \mathrm{g} / \mathrm{L} & 0.332 & \text { EPA6010A } \\ \mu \mathrm{g} / \mathrm{L} & 0.223 & \text { EPA6010A } \\ \mu \mathrm{g} / \mathrm{L} & 0.208 & \text { EPA6010A } \\ \mu \mathrm{g} / \mathrm{L} & 15.4 & \text { EPA6010A } \\ \mu \mathrm{g} / \mathrm{L} & 0.729 & \text { EPA6010A } \\ \mu \mathrm{g} / \mathrm{L} & 0.671 & \text { EPA6010A } \\ \mu \mathrm{g} / \mathrm{L} & 1.32 & \text { EPA6010A } \\ \mu \mathrm{g} / \mathrm{L} & 8.63 & \text { EPA6010A } \\ \mu \mathrm{g} / \mathrm{L} & 0.678 & \text { EPA6010A }\end{array}$

Data Summary Report for the Annual Fourmile Branch and F- and H-Area Seeplines, Appendix IX Metals and Radionuclides, 1998 (WSRC-TR-98-00260) 
SURVEY ID: HSP 09203 (cont.)

Constituent

Metals (tolal recoverable)

Magnesium

Manganese

Mercury

Nickel

Potassium

Selenium

Silver

Sodium

Thallium

Tin

Vanadium

Zinc

\section{Radionuclides}

Actinium-228

Americium-241

Antimony-124

Antimony-125

Barium-133

Cerium-144

Cesium-134

Cesium-137

Cobalt-57

Cobalt-58

Cobalt- 60

Curium-242

Curium-243/244

Curium-245/246

Europium-152

Europium-154

Europium-155

Gross alpha

Lead-212

Manganese-54

Neptunium-237

Neptunium-239

Nonvolatile beta

Potassium-40

Promethium-144

Promethium-146

Radium-226

Ruthenium-106

Sodium-22

Tin-113

Tritium

Uranium-233/234

Uranium -235

Uranium-238

Yttrium-88

Zinc-65

Zirconium-95
Sample ID: 114011

RQ AQ B Result

Unit ssMDL Method

$\mu \mathrm{g} / \mathrm{L} \quad 3.33$

EPA6010A

$\mu \mathrm{g} / \mathrm{L} \quad 0.903 \quad$ EPA6010A

$\mu \mathrm{g} / \mathrm{L} \quad 0.104 \quad$ EPA7470

$\mu \mathrm{g} / \mathrm{L} \quad 2.27 \quad$ EPA6010A

$\mu \mathrm{g} / \mathrm{L} \quad 5.87 \quad$ EPA6010A

$\mu \mathrm{g} / \mathrm{L} \quad 1.4 \quad$ EPA6010A

$\mu \mathrm{g} / \mathrm{L} \quad 0.62 \quad$ EPA6010A

$\mu \mathrm{g} / \mathrm{L} \quad 29.1 \quad$ EPA6010A

$\mu \mathrm{g} / \mathrm{L} \quad 2.63 \quad$ EPA6010A

$\mu \mathrm{g} / \mathrm{L} \quad 2.94 \quad$ EPA6010A

$\mu \mathrm{g} / \mathrm{L} \quad 0.427 \quad$ EPA6010A

$\mu \mathrm{g} / \mathrm{L} \quad 0.966 \quad$ EPA6010A
UI

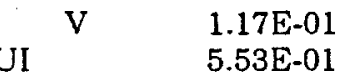

UI $3.40 \mathrm{E}+00$

UI

UI

UI

UI

UI

UI

UI

UI

UI

UI

UI

UI

UI

UI

UI

U1

UI

UI

UI

UI

UI

UI

UI

UI

UI

UI

UI
4.55E-01

$1.38 \mathrm{E}+01$

$-1.75 \mathrm{E}-01$

$-4.69 \mathrm{E}-01$

2.20E-01

$-5.77 \mathrm{E}-01$

$3.74 \mathrm{E}+00$

1.25E-02

7.23E-02

3.11E-02

$2.11 \mathrm{E}+00$

9.95E-01

7.18E-01

$2.50 \mathrm{E}+01$

$8.42 \mathrm{E}+00$

$-8.15 \mathrm{E}-02$

6.50E-04

$-4.62 \mathrm{E}+00$

$1.62 \mathrm{E}+01$

$1.56 \mathrm{E}+01$

$-5.82 \mathrm{E}-02$

4.12E-01

$1.26 \mathrm{E}+00$

$-3.35 \mathrm{E}+00$

3.69E-01

$3.95 \mathrm{E}+00$

$1.66 \mathrm{E}+02$

3.47E-01

6.97E-02

2.08E-01

$2.07 \mathrm{E}+00$

$-1.11 \mathrm{E}+00$

$8.68 \mathrm{E}+00$
$\mathrm{pCi} / \mathrm{L} \quad 2.12 \mathrm{E}+01$ EPIA-013

$\mathrm{pCi} / \mathrm{L}$ 9.05E-02 EPIA-011

$\mathrm{pCi} / \mathrm{L} \quad 5.68 \mathrm{E}+00$ EPIA-013

$\mathrm{pCi} / \mathrm{L} \quad 1.27 \mathrm{E}+01$ EPIA-013

$\mathrm{pCi} / \mathrm{L} \quad 5.52 \mathrm{E}+00$ EPIA-013

$\mathrm{pCi} / \mathrm{L} \quad 2.69 \mathrm{E}+01$ EPIA-013

$\mathrm{pCi} / \mathrm{L} \quad 4.82 \mathrm{E}+00$ EPIA-013

$\mathrm{pCi} / \mathrm{L} \quad 5.13 \mathrm{E}+00$ EPIA-013

$\mathrm{pCi} / \mathrm{L} \quad 3.33 \mathrm{E}+00$ EPIA-013

$\mathrm{pCi} / \mathrm{L} \quad 5.11 \mathrm{E}+00$ EPIA -013

$\mathrm{pCi} / \mathrm{L} \quad 5.64 \mathrm{E}+00$ EPIA-013

$\mathrm{pCi} / \mathrm{L}$ 9.71E-02 EPIA-011

pCi/L 1.51E-01 EPIA-011

$\mathrm{pCi} / \mathrm{L}$ 3.11E-02 EPIA-011

$\mathrm{pCi} / \mathrm{L}$ 1.33E+01 EPIA-013

$\mathrm{pCi} / \mathrm{L} \quad 1.39 \mathrm{E}+01$ EPIA-013

$\mathrm{pCi} / \mathrm{L} \quad 1.43 \mathrm{E}+01$ EPIA-013

$\mathrm{pCi} / \mathrm{L} \quad 2.02 \mathrm{E}+00$ EPIA-001

pCi/L 8.66E+00 EPIA-013

pCi/L 4.65E+00 EPIA-013

$\mathrm{pCi} / \mathrm{L}$ 1.23E-01 EPIA-032

pCi/L 2.46E+01 EPIA-013

pCi/L 2.48E +00 EPIA-001

$\mathrm{pCi} / \mathrm{L} \quad 4.79 \mathrm{E}+01$ EPIA-013

$\mathrm{pCi} / \mathrm{L} \quad 4.54 \mathrm{E}+00$ EPIA-013

$\mathrm{pCi} / \mathrm{L} \quad 5.95 \mathrm{E}+00$ EPIA-013

$\mathrm{pCi} / \mathrm{L}$ 4.04E-01 EPIA-008

$\mathrm{pCi} / \mathrm{L}$ 4.30E+01 EPIA-013

pCi/L $4.97 \mathrm{E}+00$ EPIA-013

$\mathrm{pCi} / \mathrm{L} \quad 6.25 \mathrm{E}+00$ EPIA-013

$\mathrm{pCi} / \mathrm{mL8.47E-01} \mathrm{EPA906.0}$

$\mathrm{pCi} / \mathrm{L}$ 1.04E-01 EPIA-011

$\mathrm{pCi} / \mathrm{L}$ 1.05E-01 EPIA-011

$\mathrm{pCi} /$ 1.04E-01 EPIA-011

$\mathrm{pCi} / \mathrm{L} \quad 6.54 \mathrm{E}+00$ EPIA-013

pCi/L 1.03E+01 EPIA-013

pCi/L 9.83E+00 EPIA-013

Data Summary Report for the Annual Fourmile Branch and

F- and H-Area Seeplines, Appendix IX Metals and Radionuclides, 1998

(WSRC-TR-98-00260) 
Table D.10 Blank Results Sorted by Sample

SURVEY ID: FSP FB02C

Sample ID: 114009

Sample type: Field Blank

Constituent

Specified Analyses

Cyanide

Cyanide

Metals (total recoverable)

Aluminum

Antimony

Arsenic

Barium

Beryllium

Cadmium

Calcium

Chromium

Cobalt

Copper

Iron

Lead

Magnesium

Manganese

Mercury

Nickel

Potassium

Selenium

Silver

Sodium

Thallium

Tin

Vanadium

Zinc

Radionuclides

Actinium-228

Antimony-124

Antimony-125

Barium-133

Cerium-144

Cesium-134

Cesium-137

Cobalt-57

Cobalt-58

Cobalt-60

Europium-152

Europium-154

Europium-155

Gross alpha

Lead-212
RQ AQ B Result

$\begin{array}{llll}\text { UJ } & \text { I } & \text { L } & 10 \\ \text { UJ } & \text { I } & \text { L } & 10\end{array}$

$\begin{array}{lll}J & E & 42.4 \\ J & E & 1.89 \\ U & & 5 \\ U & & 5 \\ U & & 5 \\ U & & 5 \\ U & V & 16.6 \\ U & & 5 \\ U & & 5 \\ U & & 5 \\ U & & 50 \\ U & & 5 \\ U & & 10 \\ U & & 10 \\ U & & 0.2 \\ U & & 5 \\ U & V & 17.2 \\ U & & 5 \\ U & V & 2.58 \\ U & V & 41.4 \\ U & & 10 \\ U & & 10 \\ U & & 5 \\ U & V & 2.49\end{array}$

UI

UI

UI

UI

UI

UI

UI

UI

UI

UI

UI

UI

UI

UI

UI
Unit ssMDL Method

$\mu \mathrm{g} / \mathrm{L} \quad 3.34$

$\mu \mathrm{g} / \mathrm{L} \quad 3.34$

EPA335.3

EPA335.3

$\begin{array}{lll}\mu \mathrm{g} / \mathrm{L} & 37.6 & \text { EPA6010A } \\ \mu \mathrm{g} / \mathrm{L} & 1.64 & \text { EPA6010A } \\ \mu \mathrm{g} / \mathrm{L} & 2.98 & \text { EPA6010A } \\ \mu \mathrm{g} / \mathrm{L} & 0.332 & \text { EPA6010A } \\ \mu \mathrm{g} / \mathrm{L} & 0.223 & \text { EPA6010A } \\ \mu \mathrm{g} / \mathrm{L} & 0.208 & \text { EPA6010A } \\ \mu \mathrm{g} / \mathrm{L} & 15.4 & \text { EPA6010A } \\ \mu \mathrm{g} / \mathrm{L} & 0.729 & \text { EPA6010A } \\ \mu \mathrm{g} / \mathrm{L} & 0.671 & \text { EPA6010A } \\ \mu \mathrm{g} / \mathrm{L} & 1.32 & \text { EPA6010A } \\ \mu \mathrm{g} / \mathrm{L} & 8.63 & \text { EPA6010A } \\ \mu \mathrm{g} / \mathrm{L} & 0.678 & \text { EPA6010A } \\ \mu \mathrm{g} / \mathrm{L} & 3.33 & \text { EPA6010A } \\ \mu \mathrm{g} / \mathrm{L} & 0.903 & \text { EPA6010A } \\ \mu \mathrm{g} / \mathrm{L} & 0.104 & \text { EPA7470 } \\ \mu \mathrm{g} / \mathrm{L} & 2.27 & \text { EPA6010A } \\ \mu \mathrm{g} / \mathrm{L} & 5.87 & \text { EPA6010A } \\ \mu \mathrm{g} / \mathrm{L} & 1.4 & \text { EPA6010A } \\ \mu \mathrm{g} / \mathrm{L} & 0.62 & \text { EPA6010A } \\ \mu \mathrm{g} / \mathrm{L} & 29.1 & \text { EPA6010A } \\ \mu \mathrm{g} / \mathrm{L} & 2.63 & \text { EPA6010A } \\ \mu \mathrm{g} / \mathrm{L} & 2.94 & \text { EPA6010A } \\ \mu \mathrm{g} / \mathrm{L} & 0.427 & \text { EPA6010A } \\ \mu \mathrm{g} / \mathrm{L} & 0.966 & \text { EPA6010A } \\ & & \end{array}$

$\mathrm{pCi} / \mathrm{L} 1.94 \mathrm{E}+01$ EPIA-013

$\mathrm{pCi} / \mathrm{L} 5.42 \mathrm{E}+00$ EPIA-013

$\mathrm{pCi} / \mathrm{L} \quad 1.02 \mathrm{E}+01$ EPIA-013

$\mathrm{pCi} / \mathrm{L} \quad 5.20 \mathrm{E}+00$ EPIA-013

pCi/L 2.68E +01 EPIA-013

$\mathrm{pCi} / \mathrm{L} \quad 4.17 \mathrm{E}+00$ EPIA-013

$\mathrm{pCi} / \mathrm{L} \quad 3.92 \mathrm{E}+00$ EPIA-013

$\mathrm{pCi} / \mathrm{L} \quad 3.33 \mathrm{E}+00$ EPIA-013

pCi $\quad 5.50 \mathrm{E}+00$ EPIA-013

$\mathrm{pCi} / \mathrm{L} \quad 5.04 \mathrm{E}+00$ EPIA-013

$\mathrm{pCi} / \mathrm{L}$ 1.20E+01 EPIA-013

$\mathrm{pCi} / \mathrm{L} \quad 1.34 \mathrm{E}+01$ EPIA-013

$\mathrm{pCi} / \mathrm{L} \quad 1.44 \mathrm{E}+01$ EPIA-013

PCi/ 4.22E-01 EPIA-001

pCi/L $8.77 \mathrm{E}+00$ EPIA-013

Data Summary Report for the Annual Fourmile Branch and

F- and H-Area Seeplines, Appendix IX Metals and Radionuclides, 1998

(WSRC-TR-98-00260) 
SURVEY ID: FSP FB02C (cont.)

Constituent

Radionuclides

Manganese-54

Neptunium-239

Nonvolatile beta

Potassium-40

Promethium-144

Promethium-146

Ruthenium-106

Sodium-22

Tin-113

Yttrium-88

Zinc-65

Zirconium-95
Sample ID: 114009

RQ AQ B Result

$2.26 \mathrm{E}+00$

$-6.16 \mathrm{E}+00$

$-2.19 \mathrm{E}-01$

$1.18 \mathrm{E}+01$

$2.45 \mathrm{E}+00$

$-1.03 \mathrm{E}+00$

$3.22 \mathrm{E}+01$

$1.51 \mathrm{E}+00$

$4.48 \mathrm{E}+00$

$-2.96 \mathrm{E}+00$

8.16E-01

$5.53 \mathrm{E}+00$

Sample ID: 114008

RQ AQ B Result

UJ I L 10

$\mu \mathrm{g} / \mathrm{L} \quad 3.34$

EPA335.3

Metals (total recoverable)

Aluminum
Antimony
Arsenic
Barium
Beryllium
Cadmium
Calcium
Chromium
Cobalt
Copper
Iron
Lead
Magnesium
Manganese
Mercury
Nickel
Potassium
Selenium
Silver
Sodium
Thallium
Tin
Vanadium
Zinc

$\begin{array}{lll}J & E & 43.2 \\ J & E & 2.32 \\ J & E & 3.81 \\ J & E & 0.597 \\ U & & 5 \\ U & & 5 \\ U & V & 17.6 \\ U & & 5 \\ U & & 5 \\ U & & 5 \\ U & & 50 \\ U & V & 1.25 \\ U & & 10 \\ U & & 10 \\ U & & 0.2 \\ U & & 5 \\ U & V & 12.8 \\ U & & 5 \\ U & V & 2.55 \\ U & V & 37.8 \\ U & & 10 \\ U & & 10 \\ U & & 5 \\ U & V & 2.43\end{array}$

Unit ssMDL Method

$\mathrm{pCi} / \mathrm{L} \quad 4.87 \mathrm{E}+00$ EPIA-013

$\mathrm{pCi} / \mathrm{L} \quad 2.38 \mathrm{E}+01$ EPIA-013

$\mathrm{pCi} / \mathrm{L} \quad 1.09 \mathrm{E}+00$ EPIA-001

$\mathrm{pCi} / \mathrm{L}$ 4.09E+01 EPIA-013

$\mathrm{pCi} / \mathrm{L} \quad 4.69 \mathrm{E}+00$ EPIA-013

$\mathrm{pCi} / \mathrm{L} \quad 5.05 \mathrm{E}+00$ EPIA-013

$\mathrm{pCi} / \mathrm{L}$ 3.63E+01 EPIA-013

$\mathrm{pCi} / \mathrm{L} \quad 4.22 \mathrm{E}+00$ EPIA-013

$\mathrm{pCi} / \mathrm{L}$ 6.05E+00 EPIA-013

$\mathrm{pCi} / \mathrm{L} \quad 5.29 \mathrm{E}+00$ EPIA-013

$\mathrm{pCi} / \mathrm{L}$ 9.10E+00 EPIA-013

$\mathrm{pCi} / \mathrm{L} \quad 9.94 \mathrm{E}+00$ EPIA-013
Specified Analyses

Cyanide

10

43.2

$\mu \mathrm{g} / \mathrm{L} \quad 37.6 \quad$ EPA6010A

$\mu \mathrm{g} / \mathrm{L} \quad 1.64 \quad$ EPA6010A

$\mu \mathrm{g} / \mathrm{L} \quad 2.98 \quad$ EPA6010A

$\mu \mathrm{g} / \mathrm{L} \quad 0.332 \quad$ EPA6010A

$\mu \mathrm{g} / \mathrm{L} \quad 0.223 \quad$ EPA6010A

$\mu \mathrm{g} / \mathrm{L} \quad 0.208 \quad$ EPA6010A

$\mu \mathrm{g} / \mathrm{L} \quad 15.4 \quad$ EPA6010A

$\mu \mathrm{g} / \mathrm{L} \quad 0.729 \quad$ EPA6010A

$\mu g / L \quad 0.671 \quad$ EPA6010A

$\mu \mathrm{g} / \mathrm{L} \quad 1.32 \quad$ EPA6010A

$\mu \mathrm{g} / \mathrm{L} \quad 8.63 \quad$ EPA6010A

$\mu \mathrm{g} / \mathrm{L} \quad 0.678 \quad$ EPA6010A

$\mu \mathrm{g} / \mathrm{L} \quad 3.33 \quad$ EPA6010A

$\mu \mathrm{g} / \mathrm{L} \quad 0.903 \quad$ EPA6010A

$\mu \mathrm{g} / \mathrm{L} \quad 0.104 \quad$ EPA7470

$\mu \mathrm{g} / \mathrm{L} \quad 2.27 \quad$ EPA6010A

$\mu \mathrm{g} / \mathrm{L} \quad 5.87 \quad$ EPA6010A

$\mu g / \mathrm{L} \quad 1.4 \quad \mathrm{EPA6010A}$

$\mu \mathrm{g} / \mathrm{L} \quad 0.62 \quad$ EPA6010A

$\mu \mathrm{g} / \mathrm{L} \quad 29.1 \quad$ ЕРA6010A

$\mu \mathrm{g} / \mathrm{L} \quad 2.63 \quad$ EPA6010A

$\mu \mathrm{g} / \mathrm{L} \quad 2.94 \quad$ EPA6010A

$\mu g / \mathrm{L} \quad 0.427 \quad$ EPA6010A

$\mu \mathrm{g} / \mathrm{L} \quad 0.966 \quad$ EPA6010A 
SURVEY ID: HSP FB02C (cont.)

\section{Constituent}

Radionuclides

Actinium-228

Antimony-124

Antimony-125

Barium-133

Cerium-144

Cesium-134

Cesium-137

Cobalt- 57

Cobalt-58

Cobalt-60

Europium-152

Europium-154

Europium-155

Gross alpha

Lead-212

Manganese-54

Neptunium-239

Nonvolatile beta

Potassium -40

Promethium-144

Promethium-146

Ruthenium-106

Sodium-22

Tin-113

Yttrium-88

Zinc-65

Zirconium-95
Sample ID: 114008

RQ AQ B Result

Unit ssMDL Method

$2.67 \mathrm{E}+00$

$1.58 \mathrm{E}+00$

$-3.24 \mathrm{E}+00$

$-1.50 \mathrm{E}+00$

$2.23 \mathrm{E}+01$

$-6.04 \mathrm{E}-01$

$-8.34 \mathrm{E}-01$

7.11E-03

2.70E-01

$-2.80 \mathrm{E}-01$

$1.91 \mathrm{E}+00$

$-7.51 \mathrm{E}-01$

$-7.24 \mathrm{E}-01$

$-7.22 \mathrm{E}-02$

$5.83 \mathrm{E}+00$

$-1.69 \mathrm{E}+00$

$3.33 \mathrm{E}+00$

5.81E-01

$4.94 \mathrm{E}+01$

$1.48 \mathrm{E}+00$

$-4.82 \mathrm{E}-01$

$2.53 \mathrm{E}+00$

$-7.84 \mathrm{E}-01$

$8.46 \mathrm{E}-01$

$4.61 \mathrm{E}-01$

$-3.41 \mathrm{E}-01$

$1.72 \mathrm{E}+00$
$\mathrm{pCi} / \mathrm{L} \quad 1.88 \mathrm{E}+01$ EPIA-013

$\mathrm{pCi} / 2 \quad 5.44 \mathrm{E}+00$ EPIA-013

$\mathrm{pCi} / \mathrm{L} \quad 1.06 \mathrm{E}+01$ EPIA-013

pCi/L 5.34E+00 EPIA-013

$\mathrm{pCi} / \mathrm{L} \quad 2.86 \mathrm{E}+01$ EPIA-013

$\mathrm{pCi} / \mathrm{L} \quad 4.13 \mathrm{E}+00$ EPIA-013

pCi/L 4.03E+00 EPIA-013

pCi/L 3.59E+00 EPIA-013

$\mathrm{pCi} / \mathrm{L} \quad 4.94 \mathrm{E}+00$ EPIA-013

pCi/L 4.87E+00 EPIA-013

$\mathrm{pCi} / \mathrm{L} \quad 1.22 \mathrm{E}+01$ EPIA-013

$\mathrm{pCi} / \mathrm{L} \quad 1.17 \mathrm{E}+01$ EPIA-013

$\mathrm{pCi} / \mathrm{L} \quad 1.42 \mathrm{E}+01$ EPIA-013

pCi/L 5.37E-01 EPIA-001

pCi/L 8.97E+00 EPIA-013

$\mathrm{pCi} / \mathrm{L} \quad 4.29 \mathrm{E}+00$ EPIA-013

pCi/L 2.69E+01 EPIA-013

$\mathrm{pCi} / \mathrm{L}$ 1.10E +00 EPIA-001

$\mathrm{pCi} / \mathrm{L}$ 6.52E+01 EPIA-013

pCi/L 4.46E+00 EPIA-013

$\mathrm{pCi} / \mathrm{L}$ 5.15E+00 EPIA-013

$\mathrm{pCi} / \mathrm{L} \quad 3.77 \mathrm{E}+01$ EPIA-013

$\mathrm{pCi} / \mathrm{L} \quad 4.21 \mathrm{E}+00$ EPIA-013

pCi/L $\quad 5.49 \mathrm{E}+00$ EPIA-013

$\mathrm{pCi} / \mathrm{L} \quad 6.02 \mathrm{E}+00$ EPIA-013

$\mathrm{pCi} / \mathrm{L} \quad 9.31 \mathrm{E}+00$ EPIA-013

pCi/L 8.60E+00 EPIA-013 


\section{D.4 Results Sorted by Analyte}

Table D.11 Sample Results Sorted by Analyte

ANALYTE: Actinium-228

Analytical Group: Radionuclides

\begin{tabular}{|c|c|c|c|c|c|c|c|c|}
\hline Survey $\mathbf{W}$ & Sample ID & $\mathbf{R Q}$ & $\mathbf{B}$ & Result & Unit & ssMDL & Method & $\mathbf{A Q}$ \\
\hline BG 00103 & 114003 & UI & & $1.15 \mathrm{E}+01$ & $\mathrm{pCi} / \mathrm{L}$ & $1.84 \mathrm{E}+01$ & EPIA-013 & \\
\hline BG 00203 & 114004 & UI & & $1.56 \mathrm{E}+01$ & $\mathrm{pCi} / \mathrm{L}$ & $2.05 E+01$ & EPIA-013 & \\
\hline BG 00303 & 114005 & UI & & $4.72 \mathrm{E}+00$ & $\mathrm{pCi} / \mathrm{L}$ & $1.94 \mathrm{E}+01$ & EPLA-013 & \\
\hline BG 00403 & 114010 & UI & & $5.62 \mathrm{E}+00$ & $\mathrm{pCi} / \mathrm{L}$ & $3.05 E+01$ & EPIA-013 & \\
\hline FMC001F03 & 114002 & $\mathrm{UI}$ & & $7.86 \mathrm{E}+00$ & $\mathrm{pCi} / \mathrm{L}$ & $1.80 \mathrm{E}+01$ & EPIA-013 & \\
\hline FMC001HO3 & 114000 & $\mathbf{R}$ & & $2.44 \mathrm{E}+01$ & $\mathrm{pCi} / \mathrm{L}$ & $2.04 \mathrm{E}+01$ & EPIA-013 & 4 \\
\hline FMC002HO3 & 114001 & UI & & $2.49 \mathrm{E}+01$ & $\mathrm{pCi} / \mathrm{L}$ & $2.57 \mathrm{E}+01$ & EPLA-013 & \\
\hline FSP 01203 & 114019 & UI & & $5.14 \mathrm{E}+00$ & $\mathrm{pCi} / \mathrm{L}$ & $1.49 \mathrm{E}+01$ & EPIA-013 & \\
\hline FSP 03203 & 114021 & UI & & $7.86 \mathrm{E}+00$ & $\mathrm{pCi} / \mathrm{L}$ & $1.61 \mathrm{E}+01$ & EPLA-013 & \\
\hline FSP 03203 & 114021 & $\mathbf{R}$ & & $2.66 \mathrm{E}+01$ & $\mathrm{pCi} / \mathrm{L}$ & $1.59 \mathrm{E}+01$ & EPIA-013 & 4 \\
\hline FSP 03203D & 114022 & UI & & $-1.10 \mathrm{E}+00$ & $\mathrm{pCi} / \mathrm{L}$ & $1.19 E+01$ & EPA901.1MOD & \\
\hline FSP 04703 & 114020 & UI & & $6.59 \mathrm{E}+00$ & $\mathrm{pCi} / \mathrm{L}$ & $1.43 \mathrm{E}+01$ & EPIA-013 & \\
\hline FSP 20403 & 114018 & UI & & $1.46 \mathrm{E}+01$ & $\mathrm{pCi} / \mathrm{L}$ & $1.67 \mathrm{E}+01$ & EPIA-013 & \\
\hline FSP 29003 & 114016 & UI & & $7.43 \mathrm{E}-01$ & $\mathrm{pCi} / \mathrm{L}$ & $1.14 \mathrm{E}+01$ & EPIA-013 & \\
\hline FSP 29003A & 114017 & UI & & $8.20 \mathrm{E}+00$ & $\mathrm{pCi} / \mathrm{L}$ & $1.51 \mathrm{E}+01$ & EPLA-013 & \\
\hline HSP 00803 & 114006 & UI & & $6.85 \mathrm{E}+00$ & $\mathrm{pCi} / \mathrm{L}$ & $1.43 \mathrm{E}+01$ & EPIA-013 & \\
\hline HSP 00803A & 114007 & UI & & $2.37 \mathrm{E}-01$ & $\mathrm{pCi} / \mathrm{L}$ & $2.05 E+01$ & EPLA-013 & \\
\hline HSP 02903 & 114014 & UI & & $1.23 \mathrm{E}+01$ & $\mathrm{pCi} / \mathrm{L}$ & $1.94 \mathrm{E}+01$ & EPIA-013 & \\
\hline HSP 02903 & 114014 & UI & & $1.28 \mathrm{E}+00$ & $\mathrm{pCi} / \mathrm{L}$ & $2.22 \mathrm{E}+01$ & EPLA-013 & \\
\hline HSP 04303 & 114015 & UI & & $9.18 \mathrm{E}+00$ & $\mathrm{pCi} / \mathrm{L}$ & $1.77 \mathrm{E}+01$ & EPIA-013 & \\
\hline HSP 06003 & 114012 & UI & & $9.35 \mathrm{E}+00$ & $\mathrm{pCi} / \mathrm{L}$ & $2.45 \mathrm{E}+01$ & EPLA-013 & \\
\hline HSP 06003D & 114013 & UI & & $3.20 \mathrm{E}+00$ & $\mathrm{pCi} / \mathrm{L}$ & $1.57 \mathrm{E}+01$ & EPA901.1MOD & \\
\hline HSP $06003 D$ & 114013 & UI & & $-2.45 E+00$ & $\mathrm{pCi} / \mathrm{L}$ & $1.51 \mathrm{E}+01$ & EPA901.1MOD & \\
\hline HSP 09203 & 114011 & UI & & $1.79 \mathrm{E}+01$ & $\mathrm{pCi} / \mathrm{L}$ & $2.12 \mathrm{E}+01$ & EPIA-013 & \\
\hline
\end{tabular}

ANALYTE: Aluminum

Analytical Group: Metals (total recoverable)

\begin{tabular}{|c|c|c|c|c|c|c|c|c|}
\hline Survey m & Sample ID & $\mathbf{R Q}$ & $\mathbf{B}$ & Result & Unit & s\$MDL & Method & $\mathbf{A Q}$ \\
\hline BG 00103 & 114003 & $\mathbf{J}$ & $\mathbf{L}$ & 209 & $\mu g / L$ & 37.6 & EPA6010A & I \\
\hline $\mathrm{BG} 00203$ & 114004 & $\mathbf{J}$ & $\bar{L}$ & 258 & $\mu \mathrm{g} / \mathrm{L}$ & 37.6 & EPA6010A & I \\
\hline BG 00303 & 114005 & $J$ & $\mathbf{L}$ & 174 & $\mu \mathrm{g} / \mathrm{L}$ & 37.6 & EPA6010A & I \\
\hline BG 00403 & 114010 & & & 453 & $\mu g / L$ & 37.6 & EPA6010A & V \\
\hline FMC001F03 & 114002 & & & 194 & $\mu \mathrm{g} / \mathrm{L}$ & 37.6 & EPA6010A & \\
\hline FMC001H03 & 114000 & & & 187 & $\mu \mathrm{g} / \mathrm{L}$ & 37.6 & EPA6010A & \\
\hline FMC002H03 & 114001 & & & 145 & $\mu \mathrm{g} / \mathrm{L}$ & 37.6 & EPA6010A & \\
\hline FSP 01203 & 114019 & & & 672 & $\mu \mathrm{g} / \mathrm{L}$ & 37.6 & EPA6010A & \\
\hline FSP 03203 & 114021 & & & 611 & $\mu g / L$ & 37.6 & EPA6010A & \\
\hline FSP 03203D & 114022 & & & 785 & $\mu \mathrm{g} / \mathrm{L}$ & 14.6 & EPA6010 & \\
\hline FSP 04703 & 114020 & & & 553 & $\mu \mathrm{g} / \mathrm{L}$ & 37.6 & EPA6010A & \\
\hline FSP 20403 & 114018 & & & 8590 & $\mu \mathrm{g} / \mathrm{L}$ & 75.2 & EPA6010A & \\
\hline FSP 29003 & 114016 & & & 391 & $\mu \mathrm{g} / \mathrm{L}$ & 37.6 & EPA6010A & \\
\hline FSP 29003A & 114017 & & & 380 & $\mu \mathrm{g} / \mathrm{L}$ & 37.6 & EPA6010A & \\
\hline HSP 00803 & 114006 & $\mathbf{J}$ & $\mathbf{L}$ & 3490 & $\mu \mathrm{g} / \mathrm{L}$ & 37.6 & EPA6010A & I \\
\hline HSP 00803A & 114007 & $\mathbf{J}$ & $\mathbf{L}$ & 3400 & $\mu g / L$ & 37.6 & EPA6010A & I \\
\hline HSP 02903 & 114014 & & & 10000 & $\mu \mathrm{g} / \mathrm{L}$ & 37.6 & EPA6010A & $\mathbf{V}$ \\
\hline HSP 04303 & 114015 & & & 469 & $\mu g / L$ & 37.6 & EPA6010A & V \\
\hline HSP 06003 & 114012 & & & 13100 & $\mu \mathrm{g} / \mathrm{L}$ & 37.6 & EPA6010A & V \\
\hline
\end{tabular}

Data Summary Report for the Annual Fourmile Branch and

F- and H-Area Seeplines, Appendix IX Metals and Radionuclides, 1998

(WSRC-TR-98-00260) 
ANALYTE: Aluminum (cont.)

\begin{tabular}{|c|c|}
\hline Survey ID & Sample ID \\
\hline HSP 06003D & 114013 \\
\hline HSP 09203 & 114011 \\
\hline
\end{tabular}

$\begin{array}{rrrl}\text { Result } & \text { Unit } & \text { ssMLL } & \text { Method } \\ 8200 & \mu \mathrm{g} / \mathrm{L} & 14.6 & \text { EPA6010 } \\ 3330 & \mu \mathrm{g} / \mathrm{L} & 37.6 & \text { EPA6010A }\end{array}$

$\begin{array}{rlrl}\text { Result } & \text { Unit } & \text { ssMDL } & \text { Method } \\ & & & \\ 7.81 \mathrm{E}-01 & \mathrm{pCi} / \mathrm{L} & 1.33 \mathrm{E}-01 & \text { EPIA-011 } \\ 6.55 \mathrm{E}-02 & \mathrm{pCi} / \mathrm{L} & 1.61 \mathrm{E}-01 & \mathrm{EPIA}-011 \\ 1.01 \mathrm{E}-01 & \mathrm{pCi} / \mathrm{L} & 1.68 \mathrm{E}-01 & \mathrm{EPIA-011} \\ 3.55 \mathrm{E}-01 & \mathrm{pCi} / \mathrm{L} & 1.83 \mathrm{E}-01 & \mathrm{EPIA-011} \\ 4.34 \mathrm{E}-02 & \mathrm{pCi} / \mathrm{L} & 1.20 \mathrm{E}-01 & \text { EPIA-011 } \\ 4.46 \mathrm{E}-02 & \mathrm{pCi} / \mathrm{L} & 6.54 \mathrm{E}-02 & \text { EPIA-011 } \\ 1.17 \mathrm{E}-01 & \mathrm{pCi} / \mathrm{L} & 9.05 \mathrm{E}-02 & \text { EPIA-011 }\end{array}$

\begin{tabular}{|c|c|c|}
\hline Survey ID & Sample D & $\mathbf{R Q}$ \\
\hline BG 00203 & 114004 & \\
\hline FSP 03203 & 114021 & UI \\
\hline FSP 03203 & 114021 & UI \\
\hline FSP 20403 & 114018 & \\
\hline HSP 00803 & 114006 & UI \\
\hline HSP 02903 & 114014 & UI \\
\hline HSP 09203 & 114011 & \\
\hline
\end{tabular}

ANACY'TE: Antimony

Analytical Group: Metals (total recoverable)

$\begin{array}{llrrrrrl}\text { Survey I } & \text { Sample D } & \text { RQ } & \text { B } & \text { Result } & \text { Unit } & \text { ssMmL } & \text { Method } \\ & & & 10 & \mu \mathrm{g} / \mathrm{L} & 1.64 & \text { EPA6010A } \\ \text { BG 00103 } & 114003 & \mathrm{U} & 10 & \mu \mathrm{g} / \mathrm{L} & 1.64 & \text { EPA6010A } \\ \text { BG 00203 } & 114004 & \mathrm{U} & 10 & \mu \mathrm{g} / \mathrm{L} & 1.64 & \text { EPA6010A } \\ \text { BG 00303 } & 114005 & \mathrm{U} & 10 & \mu \mathrm{g} / \mathrm{L} & 1.64 & \text { EPA6010A } \\ \text { BG 00403 } & 114010 & \mathrm{U} & 10 & \mu \mathrm{g} / \mathrm{L} & 1.64 & \text { EPA6010A } \\ \text { FMC001F03 } & 114002 & \mathrm{U} & 10 & \mu \mathrm{g} / \mathrm{L} & 1.64 & \text { EPA6010A } \\ \text { FMC001H03 } & 114000 & \mathrm{U} & 10 & \mu \mathrm{g} / \mathrm{L} & 1.64 & \text { EPA6010A } \\ \text { FMC002H03 } & 114001 & \mathrm{U} & 10 & \mu \mathrm{g} / \mathrm{L} & 1.64 & \text { EPA6010A } \\ \text { FSP 01203 } & 114019 & \mathrm{U} & 10 & \mu \mathrm{g} / \mathrm{L} & 1.64 & \text { EPA6010A } \\ \text { FSP 03203 } & 114021 & \mathrm{U} & 27 & \mu \mathrm{g} / \mathrm{L} & 2.7 & \text { EPA6010 } \\ \text { FSP 03203D } & 114022 & \mathrm{U} & 10 & \mu \mathrm{g} / \mathrm{L} & 1.64 & \text { EPA6010A } \\ \text { FSP 04703 } & 114020 & \mathrm{U} & 20 & \mu \mathrm{g} / \mathrm{L} & 3.28 & \text { EPA6010A } \\ \text { FSP 20403 } & 114018 & \mathrm{U} & 10 & \mu \mathrm{g} / \mathrm{L} & 1.64 & \text { EPA6010A } \\ \text { FSP 29003 } & 114016 & \mathrm{U} & 10 & \mu \mathrm{g} / \mathrm{L} & 1.64 & \text { EPA6010A } \\ \text { FSP 29003A } & 114017 & \mathrm{U} & 10 & \mu \mathrm{g} / \mathrm{L} & 1.64 & \text { EPA6010A } \\ \text { HSP 00803 } & 114006 & \mathrm{U} & 10 & \mu \mathrm{g} / \mathrm{L} & 1.64 & \text { EPA6010A } \\ \text { HSP 00803A } & 114007 & \mathrm{U} & 10 & \mu \mathrm{g} / \mathrm{L} & 1.64 & \text { EPA6010A } \\ \text { HSP 02903 } & 114014 & \mathrm{U} & 10 & \mu \mathrm{g} / \mathrm{L} & 1.64 & \text { EPA6010A } \\ \text { HSP 04303 } & 114015 & \mathrm{U} & 10 & \mu \mathrm{g} / \mathrm{L} & 1.64 & \text { EPA6010A } \\ \text { HSP 06003 } & 114012 & \mathrm{U} & 27 & \mu \mathrm{g} / \mathrm{L} & 2.7 & \text { EPA6010 } \\ \text { HSP 06003D } & 114013 & \mathrm{U} & 10 & \mu \mathrm{g} / \mathrm{L} & 1.64 & \text { EPA6010A } \\ \text { HSP 09203 } & 114011 & \mathrm{U} & & & & \end{array}$

ANALYTE: Antimony-124

Analytical Group: Radionuclides

\begin{tabular}{|c|c|c|c|c|c|c|c|}
\hline Survey ID & Sample ID & $\mathbf{R Q}$ & $\mathbf{B}$ & Result & Unit & ssMDL & Method \\
\hline BG 00103 & 114003 & UI & & $-3.38 \mathrm{E}-01$ & $\mathrm{pCi} / \mathrm{L}$ & $5.18 \mathrm{E}+00$ & EPIA-013 \\
\hline BG 00203 & 114004 & UI & & $6.98 \mathrm{E}-01$ & $\mathrm{pCi} / \mathrm{L}$ & $5.50 \mathrm{E}+00$ & EPIA-013 \\
\hline BG 00303 & 114005 & UI & & $-8.55 \mathrm{E}-01$ & $\mathrm{pCi} / \mathrm{L}$ & $5.17 \mathrm{E}+00$ & EPIA-013 \\
\hline BG 00403 & 114010 & UI & & $-2.10 \mathrm{E}+00$ & $\mathrm{pCi} / \mathrm{L}$ & $7.68 \mathrm{E}+00$ & EPIA-013 \\
\hline
\end{tabular}

Data Summary Report for the Annual Fourmile Branch and

F- and H-Area Seeplines, Appendix IX Metals and Radionuclides, 1998

(WSRC-TR-98-00260) 
ANALYTE: Antimony-124 (cont.)

\begin{tabular}{|c|c|c|c|c|c|c|c|}
\hline Survey ID & Sample ID & $\mathbf{R Q}$ & $\mathbf{B}$ & Result & Unit & ssMDL & Method \\
\hline FMC001F03 & 114002 & $\mathrm{UI}$ & & $1.99 \mathrm{E}-01$ & $\mathrm{pCi} / \mathrm{L}$ & $4.70 \mathrm{E}+00$ & EPIA-013 \\
\hline EMC001H03 & 114000 & UI & & $5.72 \mathrm{E}-01$ & $\mathrm{pCi} / \mathrm{L}$ & $5.18 \mathrm{E}+00$ & EPIA-013 \\
\hline FMC002HO3 & 114001 & UI & & $1.77 \mathrm{E}-01$ & $\mathrm{pCi} / \mathrm{L}$ & $6.11 \mathrm{E}+00$ & EPIA-013 \\
\hline ESP 01203 & 114019 & UI & & $-6.74 \mathrm{E}-01$ & $\mathrm{pCi} / \mathrm{L}$ & $3.68 \mathrm{E}+00$ & EPIA-013 \\
\hline FSP 03203 & 114021 & UI & & $-9.26 \mathrm{E}-01$ & $\mathrm{pCi} / \mathrm{L}$ & $3.83 E+00$ & EPIA-013 \\
\hline FSP 03203 & 114021 & UI & & $1.14 \mathrm{E}+00$ & $\mathrm{pCi} / \mathrm{L}$ & $3.97 E+00$ & EPIA-013 \\
\hline FSP 03203D & 114022 & UI & & $-2.61 \mathrm{E}+00$ & $\mathrm{pCi} / \mathrm{L}$ & $4.04 E+00$ & EPA901.1MOD \\
\hline FSP 04703 & 114020 & UI & & $-4.65 \mathrm{E}-01$ & $\mathrm{pCi} / \mathrm{L}$ & $3.72 \mathrm{E}+00$ & EPIA-013 \\
\hline FSP 20403 & 114018 & UI & & $1.23 \mathrm{E}+00$ & $\mathrm{pCi} / \mathrm{L}$ & $4.07 \mathrm{E}+00$ & EPIA-013 \\
\hline FSP 29003 & 114016 & UI & & $-2.08 \mathrm{E}+00$ & $\mathrm{pCi} / \mathrm{L}$ & $3.42 \mathrm{E}+00$ & EPIA-013 \\
\hline FSP 29003A & 114017 & UI & & 3.36E-01 & $\mathrm{pCi} / \mathrm{L}$ & $3.93 E+00$ & EPIA-013 \\
\hline HSP 00803 & 114006 & UI & & $1.04 \mathrm{E}+00$ & $\mathrm{pCi} / \mathrm{L}$ & $4.80 \mathrm{E}+00$ & EPIA-013 \\
\hline HSP 00803A & 114007 & UI & & $-1.58 \mathrm{E}+00$ & $\mathrm{pCi} / \mathrm{L}$ & $5.27 \mathrm{E}+00$ & EPIA-013 \\
\hline HSP 02903 & 114014 & UI & & 7.08E-01 & $\mathrm{pCi} / \mathrm{L}$ & $5.07 \mathrm{E}+00$ & EPIA-013 \\
\hline HSP 02903 & 114014 & UI & & $1.80 \mathrm{E}+00$ & $\mathrm{pCi} /$ & $5.90 \mathrm{E}+00$ & EPIA-013 \\
\hline HSP 04303 & 114015 & UI & & $2.82 \mathrm{E}+00$ & $\mathrm{pCi} / \mathrm{L}$ & $4.95 E+00$ & EPIA-013 \\
\hline HSP 06003 & 114012 & UI & & $1.90 \mathrm{E}-01$ & $\mathrm{pCi} / \mathrm{L}$ & $6.15 \mathrm{E}+00$ & EPIA-013 \\
\hline HSP 06003D & 114013 & UI & & $6.40 \mathrm{E}-01$ & $\mathrm{pCi} / \mathrm{L}$ & $5.40 \mathrm{E}+00$ & EPA901.1MOD \\
\hline HSP 06003D & 114013 & UI & & $1.80 \mathrm{E}-01$ & $\mathrm{pCi} / \mathrm{L}$ & $5.10 \mathrm{E}+00$ & EPA901.1MOD \\
\hline HSP 09203 & 114011 & UI & & $5.53 \mathrm{E}-01$ & $\mathrm{pCi} / \mathrm{L}$ & $5.68 \mathrm{E}+00$ & EPIA-013 \\
\hline
\end{tabular}

ANALYTE: Antimony-125

Analytical Group: Radionuclides

\begin{tabular}{|c|c|c|c|c|c|c|c|}
\hline Survey ID & Sample ID & $\mathbf{R Q}$ & $\mathbf{B}$ & Result & Unit & ssMDL & Method \\
\hline BG 00103 & 114003 & UI & & $6.49 E+00$ & $\mathrm{pCi} / \mathrm{L}$ & $1.21 \mathrm{E}+01$ & EPIA-013 \\
\hline BG 00203 & 114004 & UI & & $4.30 \mathrm{E}-01$ & $\mathrm{pCi} / \mathrm{L}$ & $1.26 \mathrm{E}+01$ & EPIA-013 \\
\hline BG 00303 & 114005 & UI & & $1.70 \mathrm{E}+00$ & $\mathrm{pCi} / \mathrm{L}$ & $1.07 \mathrm{E}+01$ & EPIA-013 \\
\hline BG 00403 & 114010 & UI & & $-1.32 \mathrm{E}+00$ & $\mathrm{pCi} / \mathrm{L}$ & $1.69 \mathrm{E}+01$ & EPIA-013 \\
\hline FMC001F03 & 114002 & UI & & $-1.76 \mathrm{E}+00$ & $\mathrm{pCi} / \mathrm{L}$ & $1.10 \mathrm{E}+01$ & EPIA-013 \\
\hline FMC001H03 & 114000 & UI & & $1.74 \mathrm{E}-01$ & $\mathrm{pCi} / \mathrm{L}$ & $1.20 \mathrm{E}+01$ & EPIA-013 \\
\hline $\mathrm{FMC002 \textrm {H } 0 3}$ & 114001 & UI & & $4.37 \mathrm{E}+00$ & $\mathrm{pCi} / \mathrm{L}$ & $1.42 \mathrm{E}+01$ & EPIA-013 \\
\hline FSP 01203 & 114019 & UI & & $-2.14 \mathrm{E}+00$ & $\mathrm{pCi} / \mathrm{L}$ & $8.22 \mathrm{E}+00$ & EPIA-013 \\
\hline FSP 03203 & 114021 & UI & & $2.48 \mathrm{E}+00$ & $\mathrm{pCi} / \mathrm{L}$ & $9.60 \mathrm{E}+00$ & EPIA-013 \\
\hline FSP 03203 & 114021 & UI & & 5.64E-01 & $\mathrm{pCi} / \mathrm{L}$ & $8.67 E+00$ & EPIA-013 \\
\hline FSP 03203D & 114022 & UI & & $-2.34 \mathrm{E}+00$ & $\mathrm{pCi} / \mathrm{L}$ & $7.41 E+00$ & EPA901.1MOD \\
\hline FSP 04703 & 114020 & UI & & $3.04 \mathrm{E}+00$ & $\mathrm{pCi} / \mathrm{L}$ & $9.89 \mathrm{E}+00$ & EPIA-013 \\
\hline FSP 20403 & 114018 & UI & & $-2.22 \mathrm{E}+00$ & $\mathrm{pCi} / \mathrm{L}$ & $8.68 \mathrm{E}+00$ & EPIA-013 \\
\hline FSP 29003 & 114016 & UI & & $-2.54 \mathrm{E}+00$ & $\mathrm{pCi} / \mathrm{L}$ & $8.09 \mathrm{E}+00$ & EPIA-013 \\
\hline FSP 29003A & 114017 & UI & & $-3.20 \mathrm{E}+00$ & $\mathrm{pCi} / \mathrm{L}$ & $7.88 \mathrm{E}+00$ & EPIA-013 \\
\hline HSP 00803 & 114006 & UI & & $9.35 \mathrm{E}-01$ & $\mathrm{pCi} / \mathrm{L}$ & $1.05 E+01$ & EPIA-013 \\
\hline HSP 00803A & 114007 & UI & & $5.09 \mathrm{E}+00$ & $\mathrm{pCi} / \mathrm{L}$ & $1.25 E+01$ & EPIA-013 \\
\hline HSP 02903 & 114014 & UI & & $-1.70 \mathrm{E}+00$ & $\mathrm{pCi} / \mathrm{L}$ & $1.13 \mathrm{E}+01$ & EPIA-013 \\
\hline HSP 02903 & 114014 & UI & & $1.34 \mathrm{E}+00$ & $\mathrm{pCi} / \mathrm{L}$ & $1.31 \mathrm{E}+01$ & EPIA-013 \\
\hline HSP 04303 & 114015 & UI & & $-2.33 E+00$ & $\mathrm{pCi} / \mathrm{L}$ & $1.02 \mathrm{E}+01$ & EPIA-013 \\
\hline HSP 06003 & 114012 & UI & & $2.07 \mathrm{E}+00$ & $\mathrm{pCi} / \mathrm{L}$ & $1.38 \mathrm{E}+01$ & EPIA-013 \\
\hline HSP $06003 \mathrm{D}$ & 114013 & $\mathrm{UI}$ & & $-7.40 \mathrm{E}-01$ & $\mathrm{pCi} / \mathrm{L}$ & $8.43 E+00$ & EPA901.1MOD \\
\hline HSP 06003D & 114013 & UI & & $-6.40 \mathrm{E}-01$ & $\mathrm{pCi} / \mathrm{L}$ & $9.14 \mathrm{E}+00$ & EPA901.1MOD \\
\hline HSP 09203 & 114011 & UI & & $3.40 \mathrm{E}+00$ & $\mathrm{pCi} / \mathrm{L}$ & $1.27 \mathrm{E}+01$ & EPIA-013 \\
\hline
\end{tabular}


ANALYTE: Arsenic

Analytical Group: Metals (total recoverable)

$\begin{array}{llrrrrrr}\text { Survey ID } & \text { Sample ID } & \text { RQ } & \text { B } & \text { Result } & \text { Unit } & \text { ssMDL } & \text { Method } \\ \text { BG 00103 } & 114003 & \mathrm{U} & 5 & \mu \mathrm{g} / \mathrm{L} & 2.98 & \text { EPA6010A } \\ \text { BG 00203 } & 114004 & \mathrm{U} & 5 & \mu \mathrm{g} / \mathrm{L} & 2.98 & \text { EPA6010A } \\ \text { BG 00303 } & 114005 & \mathrm{U} & 5 & \mu \mathrm{g} / \mathrm{L} & 2.98 & \text { EPA6010A } \\ \text { BG 00403 } & 114010 & \mathrm{U} & 5 & \mu \mathrm{g} / \mathrm{L} & 2.98 & \text { EPA6010A } \\ \text { FMC001F03 } & 114002 & \mathrm{U} & 5 & \mu \mathrm{g} / \mathrm{L} & 2.98 & \text { EPA6010A } \\ \text { FMC001H03 } & 114000 & \mathrm{U} & 5 & \mu \mathrm{g} / \mathrm{L} & 2.98 & \text { EPA6010A } \\ \text { FMC002H03 } & 114001 & \mathrm{U} & 5 & \mu \mathrm{g} / \mathrm{L} & 2.98 & \text { EPA6010A } \\ \text { FSP 01203 } & 114019 & \mathrm{U} & 5 & \mu \mathrm{g} / \mathrm{L} & 2.98 & \text { EPA6010A } \\ \text { FSP 03203 } & 114021 & \mathrm{U} & 5 & \mu \mathrm{g} / \mathrm{L} & 2.98 & \text { EPA6010A } \\ \text { FSP 03203D } & 114022 & \mathrm{U} & 40 & \mu \mathrm{g} / \mathrm{L} & 4 & \text { EPA6010 } \\ \text { FSP 04703 } & 114020 & \mathrm{U} & 5 & \mu \mathrm{g} / \mathrm{L} & 2.98 & \text { EPA6010A } \\ \text { FSP 20403 } & 114018 & \mathrm{U} & 10 & \mu \mathrm{g} / \mathrm{L} & 5.96 & \text { EPA6010A } \\ \text { FSP 29003 } & 114016 & \mathrm{U} & 5 & \mu \mathrm{g} / \mathrm{L} & 2.98 & \text { EPA6010A } \\ \text { FSP 29003A } & 114017 & \mathrm{U} & 5 & \mu \mathrm{g} / \mathrm{L} & 2.98 & \text { EPA6010A } \\ \text { HSP 00803 } & 114006 & \mathrm{U} & 5 & \mu \mathrm{g} / \mathrm{L} & 2.98 & \text { EPA6010A } \\ \text { HSP 00803A } & 114007 & \mathrm{U} & 5 & \mu \mathrm{g} / \mathrm{L} & 2.98 & \text { EPA6010A } \\ \text { HSP 02903 } & 114014 & \mathrm{U} & 5 & \mu \mathrm{g} / \mathrm{L} & 2.98 & \text { EPA6010A } \\ \text { HSP 04303 } & 114015 & \mathrm{U} & 5 & \mu \mathrm{g} / \mathrm{L} & 2.98 & \text { EPA6010A } \\ \text { HSP 06003 } & 114012 & \mathrm{U} & 5 & \mu \mathrm{g} / \mathrm{L} & 2.98 & \text { EPA6010A } \\ \text { HSP 06003D } & 114013 & \mathrm{U} & 40 & \mu \mathrm{g} / \mathrm{L} & 4 & \text { EPA6010 } \\ \text { HSP 09203 } & 114011 & \mathrm{U} & 5 & \mu \mathrm{g} / \mathrm{L} & 2.98 & \text { EPA6010A }\end{array}$

ANALYTE: Barium

Analytical Group: Metals (Lotal recoverable)

$\begin{array}{ll}\text { Survey ID } & \text { Sample ID RQ } \\ & \text { B } \\ \text { BG 00103 } & 114003 \\ \text { BG 00203 } & 114004 \\ \text { BG 00303 } & 114005 \\ \text { BG 00403 } & 114010 \\ \text { FMC001F03 } & 114002 \\ \text { FMC001 H03 } & 114000 \\ \text { FMC002H03 } & 114001 \\ \text { FSP 01203 } & 114019 \\ \text { FSP 03203 } & 114021 \\ \text { FSP 03203D } & 114022 \\ \text { FSP 04703 } & 114020 \\ \text { FSP 20403 } & 114018 \\ \text { FSP 29003 } & 114016 \\ \text { FSP 29003A } & 114017 \\ \text { HSP 00803 } & 114006 \\ \text { HSP 00803A } & 114007 \\ \text { HSP 02903 } & 114014 \\ \text { HSP 04303 } & 114015 \\ \text { HSP 06003 } & 114012 \\ \text { HSP 06003D } & 114013 \\ \text { HSP 09203 } & 114011\end{array}$

$\begin{array}{rlrl}\text { Result } & \text { Unit } & \text { ssMDL } & \text { Method } \\ 11.8 & \mu \mathrm{g} / \mathrm{L} & 0.332 & \text { EPA6010A } \\ 13.2 & \mu \mathrm{g} / \mathrm{L} & 0.332 & \text { EPA6010A } \\ 19.4 & \mu \mathrm{g} / \mathrm{L} & 0.332 & \text { EPA6010A } \\ 24 & \mu \mathrm{g} / \mathrm{L} & 0.332 & \text { EPA6010A } \\ 22.1 & \mu \mathrm{g} / \mathrm{L} & 0.332 & \text { EPA6010A } \\ 19.3 & \mu \mathrm{g} / \mathrm{L} & 0.332 & \text { EPA6010A } \\ 18 & \mu \mathrm{g} / \mathrm{L} & 0.332 & \text { EPA6010A } \\ 86.6 & \mu \mathrm{g} / \mathrm{L} & 0.332 & \text { EPA6010A } \\ 90 & \mu \mathrm{g} / \mathrm{L} & 0.332 & \text { EPA6010A } \\ 104 & \mu \mathrm{g} / \mathrm{L} & 0.18 & \text { EPA6010 } \\ 91.7 & \mu \mathrm{g} / \mathrm{L} & 0.332 & \text { EPA6010A } \\ 199 & \mu \mathrm{g} / \mathrm{L} & 0.664 & \text { EPA6010A } \\ 30.4 & \mu \mathrm{g} / \mathrm{L} & 0.332 & \text { EPA6010A } \\ 29.7 & \mu \mathrm{g} / \mathrm{L} & 0.332 & \text { EPA6010A } \\ 14.1 & \mu \mathrm{g} / \mathrm{L} & 0.332 & \text { EPA6010A } \\ 13 & \mu \mathrm{g} / \mathrm{L} & 0.332 & \text { EPA6010A } \\ 216 & \mu \mathrm{g} / \mathrm{L} & 0.332 & \text { EPA6010A } \\ 18.7 & \mu \mathrm{g} / \mathrm{L} & 0.332 & \text { EPA6010A } \\ 52 & \mu \mathrm{g} / \mathrm{L} & 0.332 & \text { EPA6010A } \\ 20.6 & \mu \mathrm{g} / \mathrm{L} & 0.18 & \text { EPA6010 } \\ 51.1 & \mu \mathrm{g} / \mathrm{L} & 0.332 & \text { EPA6010A }\end{array}$


ANALYTE: Barium-133

Analytical Group: Radionuclides

\begin{tabular}{|c|c|c|c|c|c|c|c|}
\hline Survey ID & Sample ID & $\mathbf{R Q}$ & $\mathbf{B}$ & Result & Unit & ssMDL & Method \\
\hline BG 00103 & 114003 & UI & & 4.28E-01 & $\mathrm{pCi} / \mathrm{L}$ & $5.45 \mathrm{E}+00$ & EPIA-013 \\
\hline BG 00203 & 114004 & UI & & $-2.63 \mathrm{E}+00$ & $\mathrm{pCi} / \mathrm{L}$ & $5.11 \mathrm{E}+00$ & EPIA-013 \\
\hline BG 00303 & 114005 & UI & & $5.21 \mathrm{E}-01$ & $\mathrm{pCi} / \mathrm{L}$ & $5.37 \mathrm{E}+00$ & EPIA-013 \\
\hline BG 00403 & 114010 & UI & & $-5.61 E+00$ & $\mathrm{pCi} / \mathrm{L}$ & $7.20 \mathrm{E}+00$ & EPIA-013 \\
\hline FMC001F03 & 114002 & UI & & $2.20 \mathrm{E}+00$ & $\mathrm{pCi} / \mathrm{L}$ & $5.51 \mathrm{E}+00$ & EPIA-013 \\
\hline FMC001H03 & 114000 & UI & & $1.11 \mathrm{E}+00$ & $\mathrm{pCi} / \mathrm{L}$ & $5.69 \mathrm{E}+00$ & EPIA-013 \\
\hline FMC002H03 & 114001 & UI & & $-3.12 E+00$ & $\mathrm{pCi} / \mathrm{L}$ & $6.15 E+00$ & EPIA-013 \\
\hline FSP 01203 & 114019 & UI & & $-7.72 \mathrm{E}-01$ & $\mathrm{pCi} / \mathrm{L}$ & $3.75 E+00$ & EPIA-013 \\
\hline FSP 03203 & 114021 & UI & & $1.69 \mathrm{E}+00$ & $\mathrm{pCi} / \mathrm{L}$ & $4.56 \mathrm{E}+00$ & EPIA-013 \\
\hline FSP 03203 & 114021 & UI & & $1.71 E+00$ & $\mathrm{pCi} / \mathrm{L}$ & $4.97 \mathrm{E}+00$ & EPIA-013 \\
\hline FSP 03203D & 114022 & UI & & $7.70 \mathrm{E}-01$ & $\mathrm{pCi} / \mathrm{L}$ & $4.12 \mathrm{E}+00$ & EPA901.1MOD \\
\hline FSP 04703 & 114020 & UI & & $-9.69 \mathrm{E}-02$ & $\mathrm{pCi} / \mathrm{L}$ & $4.32 \mathrm{E}+00$ & EPIA-013 \\
\hline FSP 20403 & 114018 & UI & & $1.99 E+00$ & $\mathrm{pCi} / \mathrm{L}$ & $4.27 \mathrm{E}+00$ & EPIA-013 \\
\hline FSP 29003 & 114016 & UI & & $-1.76 \mathrm{E}+00$ & $\mathrm{pCi} / \mathrm{L}$ & $3.38 \mathrm{E}+00$ & EPIA-013 \\
\hline FSP 29003A & 114017 & $\mathrm{R}$ & & $8.98 E+00$ & $\mathrm{pCi} / \mathrm{L}$ & $3.94 \mathrm{E}+00$ & EPIA-013 \\
\hline HSP 00803 & 114006 & UI & & 2.21E-01 & $\mathrm{pCi} / \mathrm{L}$ & $4.78 \mathrm{E}+00$ & EPIA-013 \\
\hline HSP 00803A & 114007 & UI & & $-3.47 \mathrm{E}+00$ & $\mathrm{pCi} / \mathrm{L}$ & $5.19 \mathrm{E}+00$ & EPIA-013 \\
\hline HSP 02903 & 114014 & UI & & $2.17 \mathrm{E}+00$ & $\mathrm{pCi} / \mathrm{L}$ & $5.55 \mathrm{E}+00$ & EPIA-013 \\
\hline HSP 02903 & 114014 & UI & & $-2.50 E+00$ & $\mathrm{pCi} / \mathrm{L}$ & $5.62 \mathrm{E}+00$ & EPIA-013 \\
\hline HSP 04303 & 114015 & UI & & $6.41 \mathrm{E}-01$ & $\mathrm{pCi} / \mathrm{L}$ & $4.79 \bar{E}+00$ & EPIA-013 \\
\hline HSP 06003 & 114012 & UI & & $-3.27 \mathrm{E}+00$ & $\mathrm{pCi} / \mathrm{L}$ & $6.42 \mathrm{E}+00$ & EPIA-013 \\
\hline HSP 06003D & 114013 & UI & & $2.50 \mathrm{E}-01$ & $\mathrm{pCi} / \mathrm{L}$ & $3.94 \mathrm{E}+00$ & EPA901.1MOD \\
\hline HSP 06003D & 114013 & UI & & $-5.00 \mathrm{E}-02$ & $\mathrm{pCi} / \mathrm{L}$ & $4.00 \mathrm{E}+00$ & EPA901.1MOD \\
\hline HSP 09203 & 114011 & UI & & $4.55 \mathrm{E}-01$ & $\mathrm{pCi} / \mathrm{L}$ & $5.52 \mathrm{E}+00$ & EPIA-013 \\
\hline
\end{tabular}

ANALYTE: Beryllium

Analytical Group: Metals (total recoverable)

\begin{tabular}{|c|c|c|}
\hline Survey ID & Sample ID & $R Q$ \\
\hline BG 00103 & 114003 & $\mathrm{U}$ \\
\hline BG 00203 & 114004 & $\mathrm{U}$ \\
\hline BG 00303 & 114005 & U \\
\hline BG 00403 & 114010 & $\mathrm{U}$ \\
\hline FMIC001F03 & 114002 & $\mathrm{U}$ \\
\hline FMCOO1HO3 & 114000 & $\mathrm{U}$ \\
\hline FMC002H03 & 114001 & $\mathrm{U}$ \\
\hline FSP 01203 & 114019 & $\mathrm{U}$ \\
\hline FSP 03203 & 114021 & $\mathrm{U}$ \\
\hline FSP 03203D & 114022 & $J$ \\
\hline FSP 04703 & 114020 & $\mathrm{U}$ \\
\hline FSP 20403 & 114018 & $\mathrm{~J}$ \\
\hline FSP 29003 & 114016 & $\mathrm{U}$ \\
\hline FSP 29003A & 114017 & $\mathrm{U}$ \\
\hline HSP 00803 & 114006 & $\mathrm{U}$ \\
\hline HSP 00803A & 114007 & $\mathrm{U}$ \\
\hline HSP 02903 & 114014 & $\mathrm{~J}$ \\
\hline HSP 04303 & 114015 & $\mathrm{U}$ \\
\hline HSP 06003 & 114012 & $\mathrm{U}$ \\
\hline HSP 06003D & 114013 & $\mathrm{U}$ \\
\hline HSP 09203 & 114011 & $U$ \\
\hline
\end{tabular}

$\begin{array}{rlrl}\text { Result } & \text { Unit } & \text { ssMDL } & \text { Method } \\ 5 & \mu \mathrm{g} / \mathrm{L} & 0.223 & \text { EPA6010A } \\ 5 & \mu \mathrm{g} / \mathrm{L} & 0.223 & \text { EPA6010A } \\ 5 & \mu \mathrm{g} / \mathrm{L} & 0.223 & \text { EPA6010A } \\ 5 & \mu \mathrm{g} / \mathrm{L} & 0.223 & \text { EPA6010A } \\ 5 & \mu \mathrm{g} / \mathrm{L} & 0.223 & \text { EPA6010A } \\ 5 & \mu \mathrm{g} / \mathrm{L} & 0.223 & \text { EPA6010A } \\ 5 & \mu \mathrm{g} / \mathrm{L} & 0.223 & \text { EPA6010A } \\ 5 & \mu \mathrm{g} / \mathrm{L} & 0.223 & \text { EPA6010A } \\ 5 & \mu \mathrm{g} / \mathrm{L} & 0.223 & \text { EPA6010A } \\ 0.21 & \mu \mathrm{g} / \mathrm{L} & 0.16 & \text { EPA6010 } \\ 5 & \mu \mathrm{g} / \mathrm{L} & 0.223 & \text { EPA6010A } \\ 0.737 & \mu \mathrm{g} / \mathrm{L} & 0.446 & \text { EPA6010A } \\ 5 & \mu \mathrm{g} / \mathrm{L} & 0.223 & \text { EPA6010A } \\ 5 & \mu \mathrm{g} / \mathrm{L} & 0.223 & \text { EPA6010A } \\ 5 & \mu \mathrm{g} / \mathrm{L} & 0.223 & \text { EPA6010A } \\ 5 & \mu \mathrm{g} / \mathrm{L} & 0.223 & \text { EPA6010A } \\ 1.78 & \mu \mathrm{g} / \mathrm{L} & 0.223 & \text { EPA6010A } \\ 5 & \mu \mathrm{g} / \mathrm{L} & 0.223 & \text { EPA6010A } \\ 5 & \mu \mathrm{g} / \mathrm{L} & 0.223 & \text { EPA6010A } \\ 1.6 & \mu \mathrm{g} / \mathrm{L} & 0.16 & \text { EPA6010 } \\ 5 & \mu \mathrm{g} / \mathrm{L} & 0.223 & \text { EPA6010A }\end{array}$


ANALYTE: Cadmium

Analytical Group: Melals (total recoverable)

$\begin{array}{llrrrrrr}\text { Survey ID } & \text { Sample ID } & \text { RQ } & \text { B } & \text { Result } & \text { Unit } & \text { ssMDL } & \text { Method } \\ \text { BG 00103 } & 114003 & U & 5 & \mu g / L & 0.208 & \text { EPA6010A } \\ \text { BG 00203 } & 114004 & U & 5 & \mu g / L & 0.208 & \text { EPA6010A } \\ \text { BG 00303 } & 114005 & U & 5 & \mu \mathrm{g} / \mathrm{L} & 0.208 & \text { EPA6010A } \\ \text { BG 00403 } & 114010 & U & 5 & \mu \mathrm{g} / \mathrm{L} & 0.208 & \text { EPA6010A } \\ \text { FMC001F03 } & 114002 & \mathrm{U} & 5 & \mu \mathrm{g} / \mathrm{L} & 0.208 & \text { EPA6010A } \\ \text { FMC001H03 } & 114000 & \mathrm{U} & 5 & \mu \mathrm{g} / \mathrm{L} & 0.208 & \text { EPA6010A } \\ \text { FMC002H03 } & 114001 & \mathrm{U} & 5 & \mu \mathrm{g} / \mathrm{L} & 0.208 & \text { EPA6010A } \\ \text { FSP 01203 } & 114019 & \mathrm{U} & 5 & \mu \mathrm{g} / \mathrm{L} & 0.208 & \text { EPA6010A } \\ \text { FSP 03203 } & 114021 & \mathrm{~J} & 0.678 & \mu \mathrm{g} / \mathrm{L} & 0.208 & \text { EPA6010A } \\ \text { FSP 03203D } & 114022 & & 7.1 & \mu \mathrm{g} / \mathrm{L} & 0.47 & \text { EPA6010 } \\ \text { FSP 04703 } & 114020 & \mathrm{U} & 5 & \mu \mathrm{g} / \mathrm{L} & 0.208 & \text { EPA6010A } \\ \text { FSP 20403 } & 114018 & \mathrm{~J} & 3.13 & \mu \mathrm{g} / \mathrm{L} & 0.416 & \text { EPA6010A } \\ \text { FSP 29003 } & 114016 & \mathrm{U} & 5 & \mu \mathrm{g} / \mathrm{L} & 0.208 & \text { EPA6010A } \\ \text { FSP 29003A } & 114017 & \mathrm{U} & 5 & \mu \mathrm{g} / \mathrm{L} & 0.208 & \text { EPA6010A } \\ \text { HSP 00803 } & 114006 & \mathrm{U} & 5 & \mu \mathrm{g} / \mathrm{L} & 0.208 & \text { EPA6010A } \\ \text { HSP 00803A } & 114007 & \mathrm{U} & 5 & \mu \mathrm{g} / \mathrm{L} & 0.208 & \text { EPA6010A } \\ \text { HSP 02903 } & 114014 & \mathrm{~J} & 2.13 & \mu \mathrm{g} / \mathrm{L} & 0.208 & \text { EPA6010A } \\ \text { HSP 04303 } & 114015 & \mathrm{U} & 5 & \mu \mathrm{g} / \mathrm{L} & 0.208 & \text { EPA6010A } \\ \text { HSP 06003 } & 114012 & \mathrm{U} & 5 & \mu \mathrm{g} / \mathrm{L} & 0.208 & \text { EPA6010A } \\ \text { HSP 06003D } & 114013 & \mathrm{U} & 4.7 & \mu \mathrm{g} / \mathrm{L} & 0.47 & \text { EPA6010 } \\ \text { HSP 09203 } & 114011 & \mathrm{U} & 5 & \mu \mathrm{g} / \mathrm{L} & 0.208 & \text { EPA6010A }\end{array}$

ANALYTE: Calcium

Analytical Group: Metals (total recoverable)

$\begin{array}{ll}\text { Survey ID } & \text { Sample ID RQ } \\ \text { BG 00103 } & 114003 \\ \text { BG 00203 } & 114004 \\ \text { BG 00303 } & 114005 \\ \text { BG 00403 } & 114010 \\ \text { FMC001F03 } & 114002 \\ \text { FMC001H03 } & 114000 \\ \text { FMC002H03 } & 114001 \\ \text { FSP 01203 } & 114019 \\ \text { FSP 03203 } & 114021 \\ \text { FSP 03203D } & 114022 \\ \text { FSP 04703 } & 114020 \\ \text { FSP 20403 } & 114018 \\ \text { FSP 29003 } & 114016 \\ \text { FSP 29003A } & 114017 \\ \text { HSP 00803 } & 114006 \\ \text { HSP 00803A } & 114007 \\ \text { HSP 02903 } & 114014 \\ \text { HSP 04303 } & 114015 \\ \text { HSP 06003 } & 114012 \\ \text { HSP 06003D } & 114013 \\ \text { HSP 09203 } & 114011 \\ \end{array}$

$\begin{array}{rlrl}\text { Result } & \text { Unit } & \text { ssMDL } & \text { Method } \\ 514 & \mu \mathrm{g} / \mathrm{L} & 15.4 & \text { EPA6010A } \\ 410 & \mu \mathrm{g} / \mathrm{L} & 15.4 & \text { EPA6010A } \\ 954 & \mu \mathrm{g} / \mathrm{L} & 15.4 & \text { EPA6010A } \\ 1020 & \mu \mathrm{g} / \mathrm{L} & 15.4 & \text { EPA6010A } \\ 2180 & \mu \mathrm{g} / \mathrm{L} & 15.4 & \text { EPA6010A } \\ 1380 & \mu \mathrm{g} / \mathrm{L} & 15.4 & \text { EPA6010A } \\ 2010 & \mu \mathrm{g} / \mathrm{L} & 15.4 & \text { EPA6010A } \\ 1440 & \mu \mathrm{g} / \mathrm{L} & 15.4 & \text { EPA6010A } \\ 669 & \mu \mathrm{g} / \mathrm{L} & 15.4 & \text { EPA6010A } \\ 824 & \mu \mathrm{g} / \mathrm{L} & 47.1 & \text { EPA6010 } \\ 355 & \mu \mathrm{g} / \mathrm{L} & 15.4 & \text { EPA6010A } \\ 4620 & \mu \mathrm{g} / \mathrm{L} & 30.8 & \text { EPA6010A } \\ 742 & \mu \mathrm{g} / \mathrm{L} & 15.4 & \text { EPA6010A } \\ 658 & \mu \mathrm{g} / \mathrm{L} & 15.4 & \text { EPA6010A } \\ 849 & \mu \mathrm{g} / \mathrm{L} & 15.4 & \text { EPA6010A } \\ 849 & \mu \mathrm{g} / \mathrm{L} & 15.4 & \text { EPA6010A } \\ 2230 & \mu \mathrm{g} / \mathrm{L} & 15.4 & \text { EPA6010A } \\ 1080 & \mu \mathrm{g} / \mathrm{L} & 15.4 & \text { EPA6010A } \\ 697 & \mu \mathrm{g} / \mathrm{L} & 15.4 & \text { EPA6010A } \\ 958 & \mu \mathrm{g} / \mathrm{L} & 47.1 & \text { EPA6010 } \\ 584 & \mu \mathrm{g} / \mathrm{L} & 15.4 & \text { EPA6010A }\end{array}$


ANALYTE: Cerium-144

Analytical Group: Radionuclides

\begin{tabular}{|c|c|c|c|c|c|c|c|}
\hline Survey ID & Sample ID & $\mathbf{R Q}$ & $\mathbf{B}$ & Result & Unit & ssMDL & Method \\
\hline BG 00103 & 114003 & UI & & $2.94 \mathrm{E}-01$ & $\mathrm{pCi} / \mathrm{L}$ & $2.43 E+01$ & EPIA-013 \\
\hline BG 00203 & 114004 & UI & & $1.58 \mathrm{E}+01$ & $\mathrm{pCi} / \mathrm{L}$ & $2.57 \mathrm{E}+01$ & EPIA-013 \\
\hline BG 00303 & 114005 & UI & & $-2.16 \mathrm{E}+00$ & $\mathrm{pCi} / \mathrm{L}$ & $2.54 \mathrm{E}+01$ & EPIA-013 \\
\hline BG 00403 & 114010 & UI & & $-2.12 \mathrm{E}+00$ & $\mathrm{pCi} / \mathrm{L}$ & $3.65 E+01$ & EPIA-013 \\
\hline FMC001F03 & 114002 & UI & & $-7.98 \mathrm{E}+00$ & $\mathrm{pCi} / \mathrm{L}$ & $2.72 \mathrm{E}+01$ & EPIA-013 \\
\hline FMC001H03 & 114000 & UI & & $-1.27 \mathrm{E}+01$ & $\mathrm{pCi} / \mathrm{L}$ & $2.64 \mathrm{E}+01$ & EPIA-013 \\
\hline FMC002H03 & 114001 & UI & & $1.31 \mathrm{E}+01$ & $\mathrm{pCi} / \mathrm{L}$ & $2.88 \mathrm{E}+01$ & EPIA-013 \\
\hline FSP 01203 & 114019 & UI & & $3.02 E+00$ & $\mathrm{pCi} / \mathrm{L}$ & $2.08 \mathrm{E}+01$ & EPIA-013 \\
\hline FSP 03203 & 114021 & UI & & $-1.74 \mathrm{E}+00$ & $\mathrm{pCi} / \mathrm{L}$ & $2.27 \mathrm{E}+01$ & EPIA-013 \\
\hline FSP 03203 & 114021 & UI & & $-8.00 \mathrm{E}-01$ & $\mathrm{pCi} / \mathrm{L}$ & $2.32 \mathrm{E}+01$ & EPIA-013 \\
\hline FSP 03203D & 114022 & UI & & $-1.31 E+00$ & $\mathrm{pCi} / 2$ & $1.77 \mathrm{E}+01$ & EPA901.1MOD \\
\hline FSP 04703 & 114020 & UI & & $9.46 \mathrm{E}+00$ & $\mathrm{pCi} / \mathrm{L}$ & $2.31 E+01$ & EPIA-013 \\
\hline FSP 20403 & 114018 & UI & & $4.58 \mathrm{E}+00$ & $\mathrm{pCi} / \mathrm{L}$ & $2.28 \mathrm{E}+01$ & EPIA-013 \\
\hline FSP 29003 & 114016 & UI & & $-7.56 \mathrm{E}-01$ & $\mathrm{pCi} / \mathrm{L}$ & $2.03 E+01$ & EPIA-013 \\
\hline FSP 29003A & 114017 & UI & & $1.18 \mathrm{E}+01$ & $\mathrm{pCi} / \mathrm{L}$ & $2.34 E+01$ & EPIA-013 \\
\hline HSP 00803 & 114006 & UI & & $4.20 \mathrm{E}-02$ & $\mathrm{pCi} / \mathrm{L}$ & $2.11 \mathrm{E}+01$ & EPIA-013 \\
\hline HSP 00803A & 114007 & UI & & $-4.93 \mathrm{E}-01$ & $\mathrm{pCi} / \mathrm{L}$ & $2.53 \mathrm{E}+01$ & EPIA-013 \\
\hline HSP 02903 & 114014 & UI & & $7.11 \mathrm{E}+00$ & $\mathrm{pCi} / \mathrm{L}$ & $2.91 \mathrm{E}+01$ & EPIA-013 \\
\hline HSP 02903 & 114014 & UI & & $2.32 \mathrm{E}+00$ & $\mathrm{pCi} / \mathrm{L}$ & $2.66 \mathrm{E}+01$ & EPIA-013 \\
\hline HSP 04303 & 114015 & UI & & $7.75 \mathrm{E}+00$ & $\mathrm{pCi} / \mathrm{L}$ & $2.22 \mathrm{E}+01$ & EPIA-013 \\
\hline HSP 06003 & 114012 & UI & & $7.33 \mathrm{E}+00$ & $\mathrm{pCi} / \mathrm{L}$ & $2.97 \mathrm{E}+01$ & EPIA-013 \\
\hline HSP $06003 \mathrm{D}$ & 114013 & UI & & $7.80 \mathrm{E}-01$ & $\mathrm{pCi} / \mathrm{L}$ & $1.68 \mathrm{E}+01$ & EPA901.1MOD \\
\hline HSP 06003D & 114013 & UI & & $3.10 \mathrm{E}-01$ & $\mathrm{pCi} / \mathrm{L}$ & $1.72 \mathrm{E}+01$ & EPA901.1MOD \\
\hline HSP 09203 & 114011 & UI & & $1.38 \mathrm{E}+01$ & $\mathrm{pCi} / \mathrm{L}$ & $2.69 \mathrm{E}+01$ & EPIA-013 \\
\hline
\end{tabular}

ANALYTE: Cesium-134

Analytical Group: Radionuclides

\begin{tabular}{|c|c|c|c|c|c|c|c|}
\hline Survey ID & Sample ID & $\mathbf{R Q}$ & $\mathbf{B}$ & Result & Unit & ssMDL & Method \\
\hline BG 00103 & 114003 & UI & & $-1.67 \mathrm{E}+00$ & $\mathrm{pCi} / \mathrm{L}$ & $4.55 \mathrm{E}+00$ & EPIA-013 \\
\hline BG 00203 & 114004 & UI & & $-1.30 \mathrm{E}-01$ & $\mathrm{pCi} / \mathrm{L}$ & $4.37 \mathrm{E}+00$ & EPIA-013 \\
\hline BG 00303 & 114005 & UI & & $9.79 \mathrm{E}-01$ & $\mathrm{pCi} / \mathrm{L}$ & $4.46 \mathrm{E}+00$ & EPIA-013 \\
\hline BG 00403 & 114010 & UI & & $-2.02 \mathrm{E}+00$ & $\mathrm{pCi} / \mathrm{L}$ & $6.48 \mathrm{E}+00$ & EPIA-013 \\
\hline FMC001F03 & 114002 & UI & & $-1.78 \mathrm{E}+00$ & $\mathrm{pCi} / \mathrm{L}$ & $3.63 E+00$ & EPIA-013 \\
\hline FMCOO1H03 & 114000 & UI & & $-1.92 \mathrm{E}+00$ & $\mathrm{pCi} / \mathrm{L}$ & $4.18 \mathrm{E}+00$ & EPIA-013 \\
\hline FMC002H03 & 114001 & UI & $\cdot \cdot$ & $-2.58 \mathrm{E}+00$ & $\mathrm{pCi} / \mathrm{L}$ & $5.00 \mathrm{E}+00$ & EPIA-013 \\
\hline FSP 01203 & 114019 & UI & & $5.71 \mathrm{E}-01$ & $\mathrm{pCi} / \mathrm{L}$ & $3.36 \mathrm{E}+00$ & EPIA-013 \\
\hline ESP 03203 & 114021 & UI & & $-1.30 \mathrm{E}+00$ & $\mathrm{pCi} / \mathrm{L}$ & $3.23 \mathrm{E}+00$ & EPIA-013 \\
\hline ESP 03203 & 114021 & UI & & 2.82E-01 & $\mathrm{pCi} / \mathrm{L}$ & $3.16 E+00$ & EPIA-013 \\
\hline FSP 03203D & 114022 & UI & & $-2.22 \mathrm{E}+00$ & $\mathrm{pCi} / \mathrm{L}$ & $3.06 \mathrm{E}+00$ & EPA901.1MOD \\
\hline FSP 04703 & 114020 & UI & & $-1.94 \mathrm{E}-01$ & $\mathrm{p} \mathrm{Ci} / \mathrm{L}$ & $3.28 \mathrm{E}+00$ & EPIA-013 \\
\hline FSP 20403 & 114018 & UI & & $-1.05 \mathrm{E}+00$ & $\mathrm{pCi} / \mathrm{L}$ & $3.21 \mathrm{E}+00$ & EPIA-013 \\
\hline FSP 29003 & 114016 & UI & & $1.67 \mathrm{E}+00$ & $\mathrm{pCi} / \mathrm{L}$ & $3.10 \mathrm{E}+00$ & EPIA-013 \\
\hline FSP 29003A & 114017 & UI & & $-6.55 \mathrm{E}-01$ & $\mathrm{pCi} / \mathrm{L}$ & $3.21 \mathrm{E}+00$ & EPIA-013 \\
\hline HSP 00803 & 114006 & UI & & $-3.67 \mathrm{E}-01$ & $\mathrm{p} \mathrm{Ci} / \mathrm{L}$ & $4.18 E+00$ & EPIA-013 \\
\hline HSP 00803A & 114007 & UI & & $-4.78 \mathrm{E}-01$ & $\mathrm{pCi} / \mathrm{L}$ & $4.41 \mathrm{E}+00$ & EPIA-013 \\
\hline HSP 02903 & 114014 & UI & & $-2.07 E+00$ & $\mathrm{pCi} / \mathrm{L}$ & $4.15 E+00$ & EPIA-013 \\
\hline HSP 02903 & 114014 & UI & & $-6.23 \mathrm{E}-02$ & $\mathrm{pCi} / \mathrm{L}$ & $4.66 \mathrm{E}+00$ & EPIA-013 \\
\hline HSP 04303 & 114015 & UI & & $2.43 \mathrm{E}+00$ & $\mathrm{pCi} / \mathrm{L}$ & $3.91 \mathrm{E}+00$ & EPIA-013 \\
\hline HSP 06003 & 114012 & UI & & $-1.89 E+00$ & $\mathrm{pCi} / \mathrm{L}$ & $5.02 E+00$ & EPIA-013 \\
\hline HSP 06003D & 114013 & UI & & $-1.13 E+00$ & $\mathrm{pCi} / \mathrm{L}$ & $3.94 \mathrm{E}+00$ & EPA901.1MOD \\
\hline HSP 06003D & 114013 & UI & & $9.40 \mathrm{E}-01$ & $\mathrm{pCi} / \mathrm{L}$ & $3.73 \mathrm{E}+00$ & EPA901.1MOD \\
\hline HSP 09203 & 114011 & $\mathrm{UI}$ & & $-1.75 \mathrm{E}-01$ & $\mathrm{pCi} / \mathrm{L}$ & $4.82 E+00$ & EPIA-013 \\
\hline
\end{tabular}


ANALYTE: Cesium-137

Analytical Group: Radionuclides

\begin{tabular}{|c|c|c|c|c|c|c|c|}
\hline Survey ID & Sample ID & $\mathbf{R Q}$ & $\mathbf{B}$ & Result & Unit & ssMDL & Method \\
\hline BG 00103 & 114003 & UI & & $-2.51 E+00$ & $\mathrm{pCi} / L$ & $4.08 \mathrm{E}+00$ & EPIA-013 \\
\hline BG 00203 & 114004 & UI & & $1.13 \mathrm{E}-04$ & $\mathrm{pCi} / \mathrm{L}$ & $4.94 \mathrm{E}+00$ & EPIA-013 \\
\hline BG 00303 & 114005 & UI & & $-7.11 \mathrm{E}-01$ & $\mathrm{pCi} / \mathrm{L}$ & $4.12 \mathrm{E}+00$ & EPIA-013 \\
\hline BG 00403 & 114010 & UI & & $2.21 \mathrm{E}+00$ & $\mathrm{pCi} / \mathrm{L}$ & $7.34 \mathrm{E}+00$ & EPIA-013 \\
\hline FMC001F03 & 114002 & UI & & $1.58 \mathrm{E}+00$ & $\mathrm{pCi} / \mathrm{L}$ & $4.35 \mathrm{E}+00$ & EPIA-013 \\
\hline FMC001H03 & 114000 & UI & & $3.88 \mathrm{E}+00$ & $\mathrm{pCi} / \mathrm{L}$ & $5.51 \mathrm{E}+00$ & EPIA-013 \\
\hline FMCO02H03 & 114001 & UI & & $4.96 \mathrm{E}+00$ & $\mathrm{pCi} / \mathrm{L}$ & $5.49 \mathrm{E}+00$ & EPIA-013 \\
\hline FSP 01203 & 114019 & UI & & $2.35 \mathrm{E}-01$ & $\mathrm{pCi} / \mathrm{L}$ & $3.43 E+00$ & EPIA-013 \\
\hline FSP 03203 & 114021 & UI & & $7.66 \mathrm{E}-01$ & $\mathrm{pCi} / \mathrm{L}$ & $3.86 \mathrm{E}+00$ & EPIA-013 \\
\hline FSP 03203 & 114021 & UI & & $1.67 \mathrm{E}+00$ & $\mathrm{pCi} / \mathrm{L}$ & $3.94 \mathrm{E}+00$ & EPIA-013 \\
\hline ESP 03203D & 114022 & UI & & $1.04 \mathrm{E}+00$ & $\mathrm{pCi} / \mathrm{L}$ & $3.62 \mathrm{E}+00$ & EPA901.1MOD \\
\hline FSP 04703 & 114020 & UI & & $-8.00 \mathrm{E}-01$ & $\mathrm{pCi} / \mathrm{L}$ & $3.59 \mathrm{E}+00$ & EPIA-013 \\
\hline ESP 20403 & 114018 & UI & & $-6.00 \mathrm{E}-01$ & $\mathrm{pCi} / \mathrm{L}$ & $3.22 \mathrm{E}+00$ & EPIA-013 \\
\hline FSP 29003 & 114016 & UI & & $1.96 \mathrm{E}+00$ & $\mathrm{pCi} / \mathrm{L}$ & $2.91 E+00$ & EPIA-013 \\
\hline FSP 29003A & 114017 & UI & & $-1.91 \mathrm{E}-01$ & $\mathrm{pCi} / \mathrm{L}$ & $3.25 E+00$ & EPIA-013 \\
\hline HSP 00803 & 114006 & UI & & $-2.21 \mathrm{E}-01$ & $\mathrm{pCi} / \mathrm{L}$ & $4.06 \mathrm{E}+00$ & EPIA-013 \\
\hline HSP 00803A & 114007 & UI & & $5.25 \mathrm{E} \cdot 01$ & $\mathrm{pCi} / \mathrm{L}$ & $4.75 \mathrm{E}+00$ & EPIA-013 \\
\hline HSP 02903 & 114014 & UI & & $-6.96 \mathrm{E}-01$ & $\mathrm{pCi} / \mathrm{L}$ & $4.70 \mathrm{E}+00$ & EPIA-013 \\
\hline HSP 02903 & 114014 & UI & & $3.57 \mathrm{E}-02$ & $\mathrm{pCi} / \mathrm{L}$ & $5.26 \mathrm{E}+00$ & EPIA-013 \\
\hline HSP 04303 & 114015 & UI & & $3.13 \mathrm{E}-01$ & $\mathrm{pCi} / \mathrm{L}$ & $4.07 \mathrm{E}+00$ & EPIA-013 \\
\hline HSP 06003 & 114012 & UI & & $2.33 E+00$ & $\mathrm{pCi} / \mathrm{L}$ & $6.20 \mathrm{E}+00$ & EPIA-013 \\
\hline HSP 06003D & 114013 & UI & & $1.88 \mathrm{E}+00$ & $\mathrm{pCi} / \mathrm{L}$ & $4.08 E+00$ & EPA901.1MOD \\
\hline HSP 06003D & 114013 & UI & & $-5.60 \mathrm{E}-01$ & $\mathrm{pCi} / \mathrm{L}$ & $4.06 \mathrm{E}+00$ & EPA901.1MOD \\
\hline HSP 09203 & 114011 & UI & & $-4.69 \mathrm{E}-01$ & $\mathrm{pCi} / \mathrm{L}$ & $5.13 \mathrm{E}+00$ & EPIA-013 \\
\hline
\end{tabular}

ANALYTE: Chloride

Analytical Group: Specified Analyses

$\begin{array}{ll}\text { Survey ID } & \text { Sample ID RQ } \\ & \text { B } \\ \text { BG 00103 } & 114003 \\ \text { BG 00103 } & 114003 \\ \text { BG 00203 } & 114004 \\ \text { BG 00303 } & 114005 \\ \text { BG 00403 } & 114010 \\ \text { FMC001F03 } & 114002 \\ \text { FMC001H03 } & 114000 \\ \text { FMC001H03 } & 114000 \\ \text { FMC002H03 } & 114001 \\ \text { FSP 01203 } & 114019 \\ \text { FSP 03203 } & 114021 \\ \text { FSP 03203D } & 114022 \\ \text { FSP 04703 } & 114020 \\ \text { FSP 20403 } & 114018 \\ \text { FSP 29003 } & 114016 \\ \text { FSP 29003 } & 114016 \\ \text { FSP 29003A } & 114017 \\ \text { HSP 00803 } & 114006 \\ \text { HSP 00803A } & 114007 \\ \text { HSP 02903 } & 114014 \\ \text { HSP 04303 } & 114015 \\ \text { HSP 06003 } & 114012 \\ \text { HSP 06003 } & 114012\end{array}$

$\begin{array}{llrl}\text { Result } & \text { Unit } & \text { ssMDL } & \text { Method } \\ & & 7 & \text { EPA300.0 } \\ 1460 & \mu \mathrm{g} / \mathrm{L} & 7 & \text { EPA300.0 } \\ 1610 & \mu \mathrm{g} / \mathrm{L} & 7 & \text { EPA300.0 } \\ 1690 & \mu \mathrm{g} / \mathrm{L} & 7 & \text { EPA300.0 } \\ 2380 & \mu \mathrm{g} / \mathrm{L} & 7 & \text { EPA300.0 } \\ 2150 & \mu \mathrm{g} / \mathrm{L} & 35 & \text { EPA300.0 } \\ 4090 & \mu \mathrm{g} / \mathrm{L} & 35 & \text { EPA300.0 } \\ 2110 & \mu \mathrm{g} / \mathrm{L} & 35 & \text { EPA300.0 } \\ 2090 & \mu \mathrm{g} / \mathrm{L} & 35 & \text { EPA300.0 } \\ 3660 & \mu \mathrm{g} / \mathrm{L} & 7 & \text { EPA300.0 } \\ 2380 & \mu \mathrm{g} / \mathrm{L} & 7 & \text { EPA300.0 } \\ 1810 & \mu \mathrm{g} / \mathrm{L} & 21 & \text { EPA9056 } \\ 2100 & \mu \mathrm{g} / \mathrm{L} & 7 & \text { EPA300.0 } \\ 3560 & \mu \mathrm{g} / \mathrm{L} & 7 & \text { EPA300.0 } \\ 1610 & \mu \mathrm{g} / \mathrm{L} & 7 & \text { EPA300.0 } \\ 2020 & \mu \mathrm{g} / \mathrm{L} & 7 & \text { EPA300.0 } \\ 1900 & \mu \mathrm{g} / \mathrm{L} & 7 & \text { EPA300.0 } \\ 1840 & \mu \mathrm{g} / \mathrm{L} & 7 & \text { EPA300.0 } \\ 2040 & \mu \mathrm{g} / \mathrm{L} & 7 & \text { EPA300.0 } \\ 2110 & \mu \mathrm{g} / \mathrm{L} & 7 & \text { EPA300.0 } \\ 1380 & \mu \mathrm{g} / \mathrm{L} & 7 & \text { EPA300.0 } \\ 1610 & \mu \mathrm{g} / \mathrm{L} & 7 & \text { EPA300.0 } \\ 2030 & \mu \mathrm{g} / \mathrm{L} & 7 & \text { EPA300.0 } \\ 1920 & \mu \mathrm{g} / \mathrm{L} & & \end{array}$

$\mathbf{A Q}$

V 
ANALYTE: Chloride (cont.)

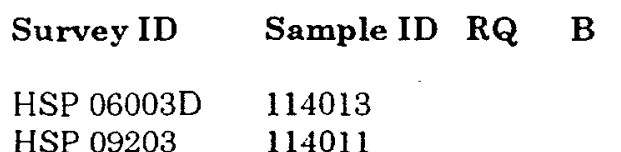

$\begin{array}{rlrl}\text { Result } & \text { Unit } & \text { ssMDL } & \text { Method } \\ 2570 & \mu \mathrm{g} / \mathrm{L} & 21 & \text { EPA9056 } \\ 1980 & \mu \mathrm{g} / \mathrm{L} & 7 & \text { EPA300.0 }\end{array}$

$\begin{array}{lll}\text { Survey ID } & \text { Sample ID } & \text { RQ } \\ \text { BG 00103 } & 114003 & \mathrm{U} \\ \text { BG 00203 } & 114004 & \mathrm{U} \\ \text { BG 00303 } & 114005 & \mathrm{U} \\ \text { BG 00403 } & 114010 & \mathrm{U} \\ \text { FMC001F03 } & 114002 & \mathrm{U} \\ \text { FMC001H03 } & 114000 & \mathrm{U} \\ \text { FMC002H03 } & 114001 & \mathrm{U} \\ \text { FSP 01203 } & 114019 & \mathrm{U} \\ \text { FSP 03203 } & 114021 & \mathrm{U} \\ \text { FSP 03203D } & 114022 & \\ \text { FSP 04703 } & 114020 & \mathrm{~J} \\ \text { FSP 20403 } & 114018 & \mathrm{U} \\ \text { FSP 29003 } & 114016 & \mathrm{U} \\ \text { FSP 29003A } & 114017 & \mathrm{U} \\ \text { HSP 00803 } & 114006 & \mathrm{~J} \\ \text { HSP 00803A } & 114007 & \mathrm{~J} \\ \text { HSP 02903 } & 114014 & \mathrm{~J} \\ \text { HSP 04303 } & 114015 & \mathrm{U} \\ \text { HSP 06003 } & 114012 & \\ \text { HSP 06003D } & 114013 & \mathrm{~J} \\ \text { HSP 09203 } & 114011 & \mathrm{~J}\end{array}$

$U$
$U$
$U$
$U$
$U$
$U$
$U$
$U$
$J$
$U$
$U$
$U$
$J$
$J$
$J$
$U$
$J$
$J$

ANALYTE: Cobalt

Analytical Group: Metals (total recoverable)

\begin{tabular}{|c|c|c|}
\hline Survey ID & Sample ID & $\mathbf{R Q}$ \\
\hline BG 00103 & 114003 & $\mathrm{U}$ \\
\hline BG 00203 & 114004 & $U$ \\
\hline BG 00303 & 114005 & $\mathbf{U}$ \\
\hline BG 00403 & 114010 & $\mathrm{U}$ \\
\hline $\mathrm{FMC001F03}$ & 114002 & $\mathrm{~J}$ \\
\hline FMCOOIHOS & 114000 & $J$ \\
\hline $\mathrm{FMCO02 \textrm {HO }}$ & 114001 & $\mathrm{U}$ \\
\hline FSP 01203 & 114019 & $J$ \\
\hline FSP 03203 & 114021 & $J$ \\
\hline FSP 03203D & 114022 & \\
\hline FSP 04703 & 114020 & $\mathrm{~J}$ \\
\hline FSP 20403 & 114018 & \\
\hline FSP 29003 & 114016 & $J$ \\
\hline FSP 29003A & 114017 & $J$ \\
\hline HSP 00803 & 114006 & $\mathrm{U}$ \\
\hline HSP 00803A & 114007 & $\mathrm{U}$ \\
\hline HSP 02903 & 114014 & \\
\hline HSP 04303 & 114015 & $\mathrm{U}$ \\
\hline
\end{tabular}

$\begin{array}{rlrl}\text { Result } & \text { Unit } & \text { ssMDL } & \text { Method } \\ & & & \\ 5 & \mu \mathrm{g} / \mathrm{L} & 0.671 & \text { EPA6010A } \\ 5 & \mu \mathrm{g} / \mathrm{L} & 0.671 & \text { EPA6010A } \\ 5 & \mu \mathrm{g} / \mathrm{L} & 0.671 & \text { EPA6010A } \\ 5 & \mu \mathrm{g} / \mathrm{L} & 0.671 & \text { EPA6010A } \\ 1.06 & \mu \mathrm{g} / \mathrm{L} & 0.671 & \text { EPA6010A } \\ 1.39 & \mu \mathrm{g} / \mathrm{L} & 0.671 & \text { EPA6010A } \\ 5 & \mu \mathrm{g} / \mathrm{L} & 0.671 & \text { EPA6010A } \\ 2.62 & \mu \mathrm{g} / \mathrm{L} & 0.671 & \text { EPA6010A } \\ 0.937 & \mu \mathrm{g} / \mathrm{L} & 0.671 & \text { EPA6010A } \\ 156 & \mu \mathrm{g} / \mathrm{L} & 0.45 & \text { EPA6010 } \\ 3.74 & \mu \mathrm{g} / \mathrm{L} & 0.671 & \text { EPA6010A } \\ 28.4 & \mu \mathrm{g} / \mathrm{L} & 1.34 & \text { EPA6010A } \\ 0.996 & \mu \mathrm{g} / \mathrm{L} & 0.671 & \text { EPA6010A } \\ 0.879 & \mu \mathrm{g} / \mathrm{L} & 0.671 & \text { EPA6010A } \\ 5 & \mu \mathrm{g} / \mathrm{L} & 0.671 & \text { EPA6010A } \\ 5 & \mu \mathrm{g} / \mathrm{L} & 0.671 & \text { EPA6010A } \\ 20.7 & \mu \mathrm{g} / \mathrm{L} & 0.671 & \text { EPA6010A } \\ 5 & \mu \mathrm{g} / \mathrm{L} & 0.671 & \text { EPA6010A }\end{array}$

$\mathbf{A Q}$

$\mathrm{E}$

E

$\mathrm{E}$

E

E

$\mathrm{E}$

Data Summary Report for the Annual Fourmile Branch and

F- and H-Area Seeplines, Appendix IX Metals and Radionuclides, 1998

(WSRC-TR-98-00260) 
ANALYTE: Cobalt (cont.)

$\begin{array}{llr}\text { Survey ID } & \text { Sample ID } & \text { RQ } \\ & & \\ \text { HSP 06003 } & 114012 & \mathrm{~J} \\ \text { HSP 06003D } & 114013 & \\ \text { HSP 09203 } & 114011 & \mathrm{U}\end{array}$

$\begin{array}{rlrl}\text { Result } & \text { Unit } & \text { ssMDL } & \text { Method } \\ 0.741 & \mu \mathrm{g} / \mathrm{L} & 0.671 & \text { EPA6010A } \\ 144 & \mu \mathrm{g} / \mathrm{L} & 0.45 & \text { EPA6010 } \\ 5 & \mu \mathrm{g} / \mathrm{L} & 0.671 & \text { EPA6010A }\end{array}$

AQ

$\mathrm{E}$<smiles>C1=CCCC=CC1</smiles>

Result Unit ssMDL Method AQ

$\begin{array}{rlll}1.26 \mathrm{E}+00 & \mathrm{pCi} / \mathrm{L} & 3.39 \mathrm{E}+00 & \text { EPIA-013 } \\ 2.75 \mathrm{E}-01 & \mathrm{pCi} / \mathrm{L} & 3.39 \mathrm{E}+00 & \text { EPIA-013 } \\ -6.67 \mathrm{E}-01 & \mathrm{pCi} / \mathrm{L} & 3.14 \mathrm{E}+00 & \text { EPIA-013 } \\ 1.80 \mathrm{E}+00 & \mathrm{pCi} / \mathrm{L} & 4.86 \mathrm{E}+00 & \text { EPIA-013 } \\ -1.17 \mathrm{E}-01 & \mathrm{pCi} / \mathrm{L} & 3.53 \mathrm{E}+00 & \text { EPIA-013 } \\ 4.88 \mathrm{E}-02 & \mathrm{pCi} / \mathrm{L} & 3.46 \mathrm{E}+00 & \text { EPIA-013 } \\ 6.51 \mathrm{E}-02 & \mathrm{pCi} / \mathrm{L} & 3.54 \mathrm{E}+00 & \text { EPIA-013 } \\ 1.12 \mathrm{E}+00 & \mathrm{pCi} / \mathrm{L} & 2.69 \mathrm{E}+00 & \text { EPIA-013 } \\ 4.99 \mathrm{E}-01 & \mathrm{pCi} / \mathrm{L} & 3.08 \mathrm{E}+00 & \text { EPIA-013 } \\ -7.19 \mathrm{E}-01 & \mathrm{pCi} / \mathrm{L} & 2.96 \mathrm{E}+00 & \text { EPIA-013 } \\ 1.80 \mathrm{E}-01 & \mathrm{pCi} / \mathrm{L} & 2.63 \mathrm{E}+00 & \text { EPA901.1MOD } \\ 7.42 \mathrm{E}-02 & \mathrm{pCi} / \mathrm{L} & 2.92 \mathrm{E}+00 & \text { EPIA-013 } \\ 1.22 \mathrm{E}+00 & \mathrm{pCi} / \mathrm{L} & 3.07 \mathrm{E}+00 & \text { EPIA-013 } \\ 1.62 \mathrm{E}-01 & \mathrm{pCi} / \mathrm{L} & 2.64 \mathrm{E}+00 & \text { EPIA-013 } \\ -5.77 \mathrm{E}-01 & \mathrm{pCi} / \mathrm{L} & 2.91 \mathrm{E}+00 & \text { EPIA-013 } \\ -5.95 \mathrm{E}-01 & \mathrm{pCi} / \mathrm{L} & 2.61 \mathrm{E}+00 & \text { EPIA-013 } \\ -1.73 \mathrm{E}+00 & \mathrm{pCi} / \mathrm{L} & 2.98 \mathrm{E}+00 & \text { EPIA-013 } \\ -6.84 \mathrm{E}-01 & \mathrm{pCi} / \mathrm{L} & 3.44 \mathrm{E}+00 & \text { EPIA-013 } \\ -5.86 \mathrm{E}-01 & \mathrm{pCi} / \mathrm{L} & 3.29 \mathrm{E}+00 & \text { EPIA-013 } \\ -1.34 \mathrm{E}-01 & \mathrm{pCi} / \mathrm{L} & 2.65 \mathrm{E}+00 & \text { EPIA-013 } \\ -8.42 \mathrm{E}-01 & \mathrm{pCi} / \mathrm{L} & 3.41 \mathrm{E}+00 & \text { EPIA-013 } \\ 7.60 \mathrm{E}-01 & \mathrm{pCi} / \mathrm{L} & 2.14 \mathrm{E}+00 & \text { EPA901.1MOD } \\ 1.10 \mathrm{E}-01 & \mathrm{pCi} / \mathrm{L} & 2.03 \mathrm{E}+00 & \text { EPA901.1MOD } \\ 2.20 \mathrm{E}-01 & \mathrm{pCi} / \mathrm{L} & 3.33 \mathrm{E}+00 & \text { EPIA-013 }\end{array}$

ANALYTE: Cobalt-57

Analytical Group: Radionuclides

$\begin{array}{lll}\text { Survey ID } & \text { Sample ID } & \text { RQ } \\ \text { BG 00103 } & 114003 & \text { UI } \\ \text { BG 00203 } & 114004 & \text { UI } \\ \text { BG 00303 } & 114005 & \text { UI } \\ \text { BG 00403 } & 114010 & \text { UI } \\ \text { FMC001F03 } & 114002 & \text { UI } \\ \text { FMC001H03 } & 114000 & \text { UI } \\ \text { FMC002H03 } & 114001 & \text { UI } \\ \text { FSP 01203 } & 114019 & \text { UI } \\ \text { FSP 03203 } & 114021 & \text { UI } \\ \text { FSP 03203 } & 114021 & \text { UI } \\ \text { FSP 03203D } & 114022 & \text { UI } \\ \text { FSP 04703 } & 114020 & \text { UI } \\ \text { FSP 20403 } & 114018 & \text { UI } \\ \text { FSP 29003 } & 114016 & \text { UI } \\ \text { FSP 29003A } & 114017 & \text { UI } \\ \text { HSP 00803 } & 114006 & \text { UI } \\ \text { HSP 00803A } & 114007 & \text { UI } \\ \text { HSP 02903 } & 114014 & \text { UI } \\ \text { HSP 02903 } & 114014 & \text { UI } \\ \text { HSP 04303 } & 114015 & \text { UI } \\ \text { HSP 06003 } & 114012 & \text { UI } \\ \text { HSP 06003D } & 114013 & \text { UI } \\ \text { HSP 06003D } & 114013 & \text { UI } \\ \text { HSP 09203 } & 114011 & \text { UI }\end{array}$

ANALYTE: Cobalt-58

Analytical Group: Radionuclides

\begin{tabular}{|c|c|c|}
\hline Survey ID & Sample ID & $\mathbf{R Q}$ \\
\hline BG 00103 & 114003 & Ul \\
\hline BG 00203 & 114004 & UI \\
\hline BG 00303 & 114005 & UI \\
\hline BG 00403 & 114010 & Ul \\
\hline FMC001F03 & 114002 & UI \\
\hline FMCOOLHO3 & 114000 & UI \\
\hline FMC002Ho3 & 114001 & UI \\
\hline FSP 01203 & 114019 & UI \\
\hline FSP 03203 & 114021 & UI \\
\hline FSP 03203 & 114021 & UI \\
\hline FSP 03203D & 114022 & UI \\
\hline FSP 04703 & 114020 & UI \\
\hline FSP 20403 & 114018 & UI \\
\hline FSP 29003 & 114016 & UI \\
\hline FSP 29003A & 114017 & UI \\
\hline
\end{tabular}

$\mathbf{A Q}$

$\begin{array}{rlll}1.66 \mathrm{E}+00 & \mathrm{pCi} / \mathrm{L} & 4.73 \mathrm{E}+00 & \mathrm{EPIA-013} \\ -1.90 \mathrm{E}+00 & \mathrm{pCi} / \mathrm{L} & 4.84 \mathrm{E}+00 & \mathrm{EPIA-013} \\ -2.17 \mathrm{E}+00 & \mathrm{pCi} / \mathrm{L} & 4.57 \mathrm{E}+00 & \mathrm{EPIA-013} \\ -1.53 \mathrm{E}+00 & \mathrm{pCi} / \mathrm{L} & 6.84 \mathrm{E}+00 & \mathrm{EPIA-013} \\ -5.42 \mathrm{E}-01 & \mathrm{pCi} / \mathrm{L} & 4.34 \mathrm{E}+00 & \mathrm{EPIA-013} \\ -2.11 \mathrm{E}-01 & \mathrm{pCi} / \mathrm{L} & 4.72 \mathrm{E}+00 & \mathrm{EPIA}-013 \\ 1.05 \mathrm{E}+00 & \mathrm{pCi} / \mathrm{L} & 5.41 \mathrm{E}+00 & \mathrm{EPIA-013} \\ -2.04 \mathrm{E}-01 & \mathrm{pCi} / \mathrm{L} & 3.12 \mathrm{E}+00 & \mathrm{EPIA-013} \\ 1.10 \mathrm{E}-01 & \mathrm{pCi} / \mathrm{L} & 3.98 \mathrm{E}+00 & \mathrm{EPIA-013} \\ 2.83 \mathrm{E}-01 & \mathrm{pCi} / \mathrm{L} & 3.67 \mathrm{E}+00 & \mathrm{EPIA-013} \\ -1.70 \mathrm{E}-01 & \mathrm{pCi} / \mathrm{L} & 3.80 \mathrm{E}+00 & \mathrm{EPA901.1MOD} \\ 1.08 \mathrm{E}+00 & \mathrm{pCi} / \mathrm{L} & 4.01 \mathrm{E}+00 & \mathrm{EPIA-013} \\ 8.87 \mathrm{E}-02 & \mathrm{pCi} / \mathrm{L} & 3.61 \mathrm{E}+00 & \mathrm{EPIA-013} \\ 9.43 \mathrm{E}-01 & \mathrm{pCi} / \mathrm{L} & 3.38 \mathrm{E}+00 & \mathrm{EPIA-013} \\ -1.58 \mathrm{E}+00 & \mathrm{pCi} / \mathrm{L} & 3.17 \mathrm{E}+00 & \mathrm{EPIA-013}\end{array}$

Data Summary Report for the Annual Fourmile Branch and F- and H-Area Seeplines, Appendix IX Metals and Radionuclides, 1998 
ANALYTE: Cobalt-58 (cont.)

$\begin{array}{lll}\text { Survey ID } & \text { Sample ID } & \text { RQ } \\ \text { HSP 00803 } & 114006 & \text { UI } \\ \text { HSP 00803A } & 114007 & \text { UI } \\ \text { HSP 02903 } & 114014 & \text { UI } \\ \text { HSP 02903 } & 114014 & \text { UI } \\ \text { HSP 04303 } & 114015 & \text { UI } \\ \text { HSP 06003 } & 114012 & \text { UI } \\ \text { HSP 06003D } & 114013 & \text { UI } \\ \text { HSP 06003D } & 114013 & \text { UI } \\ \text { HSP 09203 } & 114011 & \text { UI }\end{array}$

$\begin{array}{rlrl}\text { Result } & \text { Unit } & \text { ssMDL } & \text { Method } \\ & & & \\ 2.61 \mathrm{E}-01 & \mathrm{pCi} / \mathrm{L} & 4.10 \mathrm{E}+00 & \text { EPIA-013 } \\ 6.14 \mathrm{E}-02 & \mathrm{pCi} / \mathrm{L} & 4.64 \mathrm{E}+00 & \text { EPIA-013 } \\ 1.75 \mathrm{E}+00 & \mathrm{pCi} / \mathrm{L} & 4.94 \mathrm{E}+00 & \mathrm{EPIA}-013 \\ -1.50 \mathrm{E}+00 & \mathrm{pCi} / \mathrm{L} & 5.47 \mathrm{E}+00 & \mathrm{EPIA}-013 \\ -6.19 \mathrm{E}-01 & \mathrm{pCi} / \mathrm{L} & 3.90 \mathrm{E}+00 & \mathrm{EPIA}-013 \\ 3.38 \mathrm{E}-01 & \mathrm{pCi} / \mathrm{L} & 6.17 \mathrm{E}+00 & \mathrm{EPIA-013} \\ -1.03 \mathrm{E}+00 & \mathrm{pCi} / \mathrm{L} & 4.63 \mathrm{E}+00 & \mathrm{EPA901.1MOD} \\ -2.50 \mathrm{E}-01 & \mathrm{pCi} / \mathrm{L} & 5.01 \mathrm{E}+00 & \text { EPA901.1MOD } \\ -5.77 \mathrm{E}-01 & \mathrm{pCi} / \mathrm{L} & 5.11 \mathrm{E}+00 & \text { EPIA-013 }\end{array}$

$\mathbf{A Q}$

ANALYTE: Cobalt-60

Analytical Group: Radionuclides

\begin{tabular}{|c|c|c|c|c|c|c|c|}
\hline Survey ID & Sample ID & $\mathbf{R Q}$ & $\mathbf{B}$ & Result & Unit & ssMDL & Method \\
\hline BG 00103 & 114003 & UI & & $1.38 \mathrm{E}+00$ & $\mathrm{pCi} / \mathrm{L}$ & $4.80 \mathrm{E}+00$ & EPIA-013 \\
\hline BG 00203 & 114004 & UI & & $-2.45 \mathrm{E}+00$ & $\mathrm{pCi} / \mathrm{L}$ & $4.60 \mathrm{E}+00$ & EPIA-013 \\
\hline BG 00303 & 114005 & UI & & 1.54E-0I & $\mathrm{pCi} / \mathrm{L}$ & $4.82 \mathrm{E}+00$ & EPIA-013 \\
\hline BG 00403 & 114010 & UI & & $-3.89 \mathrm{E}-01$ & $\mathrm{pCi} / \mathrm{L}$ & $7.11 \mathrm{E}+00$ & EPIA-013 \\
\hline FMC001F03 & 114002 & UI & & $-2.36 E+00$ & $\mathrm{pCi} / \mathrm{L}$ & $4.36 \mathrm{E}+00$ & EPIA-013 \\
\hline FMC001H03 & 114000 & UI & & $-4.68 \mathrm{E}-01$ & $\mathrm{pCi} / \mathrm{L}$ & $5.37 \mathrm{E}+00$ & EPIA-013 \\
\hline EMC0O2H03 & 114001 & UI & & $2.80 \mathrm{E}+00$ & $\mathrm{pCi} / \mathrm{L}$ & $6.95 E+00$ & EPIA-013 \\
\hline FSP 01203 & 114019 & UI & & $8.02 \mathrm{E}-02$ & $\mathrm{pCi} / \mathrm{L}$ & $3.73 E+00$ & EPIA-013 \\
\hline FSP 03203 & 114021 & UI & & $-2.12 \mathrm{E}-02$ & $\mathrm{pCi} / \mathrm{L}$ & $4.02 \mathrm{E}+00$ & EPIA-013 \\
\hline FSP 03203 & 114021 & UI & & $1.13 \mathrm{E}-01$ & $\mathrm{pCi} / \mathrm{L}$ & $4.03 E+00$ & EPIA-013 \\
\hline FSP 03203D & 114022 & UI & & $7.10 \mathrm{E}-01$ & $\mathrm{pCi} / \mathrm{L}$ & $3.52 \mathrm{E}+00$ & EPA901.1MOD \\
\hline FSP 04703 & 114020 & UI & & $6.24 \mathrm{E}-01$ & $\mathrm{pCi} / \mathrm{L}$ & $3.51 \mathrm{E}+00$ & EPIA-013 \\
\hline FSP 20403 & 114018 & UI & & $1.41 E+00$ & $\mathrm{pCi} / \mathrm{L}$ & $4.55 \mathrm{E}+00$ & EPIA-013 \\
\hline FSP 29003 & 114016 & UI & & $3.60 \mathrm{E}-02$ & $\mathrm{pCi} / \mathrm{L}$ & $2.66 \mathrm{E}+00$ & EPIA-013 \\
\hline FSP 29003A & 114017 & UI & & $-2.75 \mathrm{E}-01$ & $\mathrm{pCi} / \mathrm{L}$ & $3.35 \mathrm{E}+00$ & EPIA-013 \\
\hline HSP 00803 & 114006 & UI & & $3.95 \mathrm{E}+00$ & $\mathrm{pCi} / \mathrm{L}$ & $4.90 \mathrm{E}+00$ & EPIA-013 \\
\hline HSP 00803A & 114007 & UI & & $-1.96 \mathrm{E}+00$ & $\mathrm{pCi} / \mathrm{L}$ & $4.56 \mathrm{E}+00$ & EPIA-013 \\
\hline HSP 02903 & 114014 & & & $3.83 \mathrm{E}+01$ & $\mathrm{pCi} / \mathrm{L}$ & $5.35 \mathrm{E}+00$ & EPIA-013 \\
\hline HSP 02903 & 114014 & & & $3.64 \mathrm{E}+01$ & $\mathrm{pCi} / \mathrm{L}$ & $4.65 E+00$ & EPIA-013 \\
\hline HSP 04303 & 114015 & UI & & $3.88 \mathrm{E}-02$ & $\mathrm{pCi} / \mathrm{L}$ & $4.32 \mathrm{E}+00$ & EPIA-013 \\
\hline HSP 06003 & 114012 & UI & & $2.09 E+00$ & $\mathrm{pCi} / \mathrm{L}$ & $6.24 E+00$ & EPIA-013 \\
\hline HSP 06003D & 114013 & UI & & $-1.03 \mathrm{E}+00$ & $\mathrm{pCi} / \mathrm{L}$ & $3.45 \mathrm{E}+00$ & EPA901.1MOD \\
\hline HSP $06003 \mathrm{D}$ & 114013 & UI & & $-2.20 \mathrm{E}-01$ & $\mathrm{pCi} / \mathrm{L}$ & $4.03 \mathrm{E}+00$ & EPA901.1MOD \\
\hline HSP 09203 & 114011 & UI & & $3.74 \mathrm{E}+00$ & $\mathrm{pCi} / \mathrm{L}$ & $5.64 \mathrm{E}+00$ & EPIA-013 \\
\hline
\end{tabular}

ANALYTE: Copper

Analytical Group: Metals (lolal recoverable)

\begin{tabular}{|c|c|c|c|c|c|c|c|}
\hline Survey ID & Sample ID & $\mathbf{R Q} \quad \mathbf{B}$ & Result & Unit & ssMDL & Method & $\mathbf{A Q}$ \\
\hline BG 00103 & 114003 & $\mathrm{U}$ & 5 & $\mu_{\mathrm{g}} / \mathrm{L}$ & 1.32 & EPA6010A & \\
\hline BG 00203 & 114004 & $\mathrm{U}$ & 5 & $\mu \mathrm{g} / \mathrm{L}$ & 1.32 & EPA6010A & \\
\hline BG 00303 & 114005 & $\mathrm{U}$ & 5 & $\mu \mathrm{g} / \mathrm{L}$ & 1.32 & EPA6010A & \\
\hline BG 00403 & 114010 & $\mathrm{U}$ & 5 & $\mu \mathrm{g} / \mathrm{L}$ & 1.32 & EPA6010A & \\
\hline FMC001F03 & 114002 & $\mathrm{~J}$ & 1.54 & $\mu \mathrm{g} / \mathrm{L}$ & 1.32 & EPA6010A & $\mathrm{E}$ \\
\hline FMC001H03 & 114000 & $J$ & 4.34 & $\mu \mathrm{g} / \mathrm{L}$ & 1.32 & EPA6010A & $\mathrm{E}$ \\
\hline FMC002H03 & 114001 & $J$ & 4.82 & $\mu_{\mathrm{g}} / \mathrm{L}$ & 1.32 & EPA6010A & $\mathrm{E}$ \\
\hline FSP 01203 & 114019 & $U$ & 5 & $\mu \mathrm{g} / \mathrm{L}$ & 1.32 & EPA6010A & \\
\hline FSP 03203 & 114021 & $\mathrm{U}$ & 5 & $\mu \mathrm{g} / \mathrm{L}$ & 1.32 & EPA6010A & \\
\hline
\end{tabular}


ANALYTE: Copper (cont.)

\begin{tabular}{|c|c|c|c|c|c|c|c|}
\hline Survey ID & Sample ID & $\mathbf{R Q}$ & B & Result & Unit & ssMDL & Method \\
\hline FSP 03203D & 114022 & & & 15 & $\mu \mathrm{g} / \mathrm{L}$ & 1.5 & EPA6010 \\
\hline FSP 04703 & 114020 & $\mathrm{U}$ & & 5 & $\mu \mathrm{g} / \mathrm{L}$ & 1.32 & EPA6010A \\
\hline FSP 20403 & 114018 & $\mathrm{U}$ & & 10 & $\mu \mathrm{g} / \mathrm{L}$ & 2.64 & EPA6010A \\
\hline FSP 29003 & 114016 & $\mathrm{U}$ & & 5 & $\mu \mathrm{g} / \mathrm{L}$ & 1.32 & EPA6010A \\
\hline FSP 29003A & 114017 & $\mathrm{U}$ & & 5 & $\mu \mathrm{g} / \mathrm{L}$ & 1.32 & EPA6010A \\
\hline HSP 00803 & 114006 & $\mathrm{U}$ & & 5 & $\mu \mathrm{g} / \mathrm{L}$ & 1.32 & EPA6010A \\
\hline HSP 00803A & 114007 & $\mathrm{U}$ & & 5 & $\mu g / L$ & 1.32 & EPA6010A \\
\hline HSP 02903 & 114014 & $J$ & & 2.75 & $\mu \mathrm{g} / \mathrm{L}$ & 1.32 & EPA6010A \\
\hline HSP 04303 & 114015 & $\mathrm{U}$ & & 5 & $\mu g / L$ & 1.32 & EPA6010A \\
\hline HSP 06003 & 114012 & $\mathrm{U}$ & & 5 & $\mu \mathrm{g} / \mathrm{L}$ & 1.32 & EPA6010A \\
\hline HSP $06003 \mathrm{D}$ & 114013 & & & 17.3 & $\mu \mathrm{g} / \mathrm{L}$ & 1.5 & EPA6010 \\
\hline HSP 09203 & 114011 & $\mathrm{U}$ & & 5 & $\mu \mathrm{g} / \mathrm{L}$ & 1.32 & EPA6010A \\
\hline
\end{tabular}

AQ

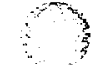

E

$\begin{array}{rlrl}\text { Result } & \text { Unit } & \text { ssMDL } & \text { Method } \\ & & & \\ 9.27 \mathrm{E}-03 & \mathrm{pCi} / \mathrm{L} & 1.18 \mathrm{E}-01 & \text { EPIA-011 } \\ -1.06 \mathrm{E}-02 & \mathrm{pCi} / \mathrm{L} & 2.33 \mathrm{E}-01 & \text { EPIA-011 } \\ -3.31 \mathrm{E}-02 & \mathrm{pCi} / \mathrm{L} & 3.20 \mathrm{E}-01 & \text { EPIA-011 } \\ 1.00 \mathrm{E}-01 & \mathrm{pCi} / \mathrm{L} & 1.51 \mathrm{E}-01 & \text { EPIA-011 } \\ -6.46 \mathrm{E}-03 & \mathrm{pCi} / \mathrm{L} & 1.09 \mathrm{E}-01 & \text { EPIA-011 } \\ 0.00 \mathrm{E}+00 & \mathrm{pCi} / \mathrm{L} & 3.79 \mathrm{E}-02 & \text { EPIA-011 } \\ 1.25 \mathrm{E}-02 & \mathrm{pCi} / \mathrm{L} & 9.71 \mathrm{E}-02 & \text { EPIA-011 }\end{array}$

AQ

$\begin{array}{lll}\text { Survey ID } & \text { Sample ID } & \text { RQ } \\ \text { BG 00203 } & 114004 & \text { UI } \\ \text { FSP 03203 } & 114021 & \text { UI } \\ \text { FSP 03203 } & 114021 & \text { UI } \\ \text { FSP 20403 } & 114018 & \text { UI } \\ \text { HSP 00803 } & 114006 & \text { UI } \\ \text { HSP 02903 } & 114014 & \text { UI } \\ \text { HSP 09203 } & 114011 & \text { UI }\end{array}$

ANALYTE: Curium-243/244

Analytical Group: Radionuclides

$\begin{array}{llll}\text { Survey ID } & \text { Sample ID } & \text { RQ } & \text { B } \\ \text { BG 00203 } & 114004 & & \\ \text { FSP 03203 } & 114021 & \text { UI } & \\ \text { FSP 03203 } & 114021 & \text { UI } & \\ \text { FSP 20403 } & 114018 & & \\ \text { HSP 00803 } & 114006 & \text { UI } \\ \text { HSP 02903 } & 114014 & \text { UI } & \\ \text { HSP 09203 } & 114011 & \text { UI } & \end{array}$

ANALYTE: Curium-245/246

Analytical Group: Radionuclides

$\begin{array}{llll}\text { Survey ID } & \text { Sample ID } & \text { RQ } & \text { B } \\ & & & \\ \text { BG 00203 } & 114004 & \text { UI } & \\ \text { FSP 03203 } & 114021 & \text { UI } & \\ \text { FSP 03203 } & 114021 & \text { UI } & \\ \text { FSP 20403 } & 114018 & \text { UI } & \\ \text { HSP 00803 } & 114006 & \text { UI } & \\ \text { HSP 02903 } & 114014 & \text { UI } & \\ \text { HSP 09203 } & 114011 & \text { UI } & \end{array}$

$\begin{array}{cccl}\text { Result } & \text { Unit } & \text { ssMDL } & \text { Method } \\ & & & \\ 1.53 \mathrm{E}-01 & \mathrm{pCi} / \mathrm{L} & 1.47 \mathrm{E}-01 & \text { EPIA-011 } \\ 1.15 \mathrm{E}-01 & \mathrm{pCi} / \mathrm{L} & 1.62 \mathrm{E}-01 & \text { EPIA-011 } \\ 8.85 \mathrm{E}-02 & \mathrm{pCi} / \mathrm{L} & 1.69 \mathrm{E}-01 & \text { EPIA-011 } \\ 3.07 \mathrm{E}-01 & \mathrm{pCi} / \mathrm{L} & 1.85 \mathrm{E}-01 & \text { EPIA-011 } \\ 3.54 \mathrm{E}-02 & \mathrm{pCi} / \mathrm{L} & 1.32 \mathrm{E}-01 & \text { EPIA-011 } \\ 3.64 \mathrm{E}-02 & \mathrm{pCi} / \mathrm{L} & 6.56 \mathrm{E}-02 & \text { EPIA-011 } \\ 7.23 \mathrm{E}-02 & \mathrm{pCi} / \mathrm{L} & 1.51 \mathrm{E}-01 & \text { EPIA-011 }\end{array}$

$\begin{array}{rlrl}\text { Result } & \text { Unit } & \text { ssMDL } & \text { Method } \\ & & & \\ 4.57 \mathrm{E}-02 & \mathrm{pCi} / \mathrm{L} & 4.57 \mathrm{E}-02 & \text { EPIA-011 } \\ 0.00 \mathrm{E}+00 & \mathrm{pCi} / \mathrm{L} & 9.12 \mathrm{E}-02 & \text { EPIA-011 } \\ 3.18 \mathrm{E}-02 & \mathrm{pCi} / \mathrm{L} & 9.53 \mathrm{E}-02 & \text { EPIA-011 } \\ 0.00 \mathrm{E}+00 & \mathrm{pCi} / \mathrm{L} & 1.04 \mathrm{E}-01 & \text { EPIA-011 } \\ 0.00 \mathrm{E}+00 & \mathrm{pCi} / \mathrm{L} & 3.06 \mathrm{E}-02 & \text { EPIA-011 } \\ 2.07 \mathrm{E}-02 & \mathrm{pCi} / \mathrm{L} & 3.11 \mathrm{E}-02 & \text { EPIA-011 } \\ 3.11 \mathrm{E}-02 & \mathrm{pCi} / \mathrm{L} & 3.11 \mathrm{E}-02 & \text { EPIA-011 }\end{array}$

AQ

AQ

Data Summary Report for the Annual Fourmile Branch and

F- and H-Area Seeplines, Appendix IX Metals and Radionuclides, 1998

(WSRC-TR-98-00260) 
ANALYTE: Cyanide

Analytical Group: Specified Analyses

$\begin{array}{llrl}\text { Survey ID } & \text { Sample ID } & \text { RQ } & \text { B } \\ \text { BG 00103 } & 114003 & \text { UJ } & \text { L } \\ \text { BG 00203 } & 114004 & \text { UJ } & \text { L } \\ \text { BG 00303 } & 114005 & \text { UJ } & \text { L } \\ \text { BG 00403 } & 114010 & \text { UJ } & \text { L } \\ \text { FMC001F03 } & 114002 & \text { UJ } & \text { L } \\ \text { FMC001H03 } & 114000 & \text { UJ } & \text { L } \\ \text { FMC002H03 } & 114001 & \text { UJ } & \text { L } \\ \text { FSP 01203 } & 114019 & \text { U } & \\ \text { FSP 03203 } & 114021 & \text { U } & \\ \text { FSP 03203D } & 114022 & \text { U } & \\ \text { FSP 04703 } & 114020 & \text { U } & \\ \text { FSP 20403 } & 114018 & \text { U } & \\ \text { FSP 29003 } & 114016 & \text { U } & \\ \text { FSP 29003A } & 114017 & \text { U } & \\ \text { HSP 00803 } & 114006 & \text { UJ } & \text { L } \\ \text { HSP 00803A } & 114007 & \text { UJ } & \text { L } \\ \text { HSP 00803A } & 114007 & \text { UJ } & \text { L } \\ \text { HSP 02903 } & 114014 & \text { UJ } & \text { L } \\ \text { HSP 04303 } & 114015 & \text { UJ } & \text { L } \\ \text { HSP 06003 } & 114012 & \text { UJ } & \text { L } \\ \text { HSP 06003D } & 114013 & \text { U } & \text {. } \\ \text { HSP 06003D } & 114013 & \text { U } & \\ \text { HSP 09203 } & 114011 & \text { UJ } & \text { L }\end{array}$

$\begin{array}{rr}\text { Result } & \text { Unit } \\ 10 & \mu \mathrm{g} / \mathrm{L} \\ 10 & \mu \mathrm{g} / \mathrm{L} \\ 10 & \mu \mathrm{g} / \mathrm{L} \\ 10 & \mu \mathrm{g} / \mathrm{L} \\ 10 & \mu \mathrm{g} / \mathrm{L} \\ 10 & \mu \mathrm{g} / \mathrm{L} \\ 10 & \mu \mathrm{g} / \mathrm{L} \\ 10 & \mu \mathrm{g} / \mathrm{L} \\ 10 & \mu \mathrm{g} / \mathrm{L} \\ 15.2 & \mu \mathrm{g} / \mathrm{L} \\ 10 & \mu \mathrm{g} / \mathrm{L} \\ 10 & \mu \mathrm{g} / \mathrm{L} \\ 10 & \mu \mathrm{g} / \mathrm{L} \\ 10 & \mu \mathrm{g} / \mathrm{L} \\ 10 & \mu \mathrm{g} / \mathrm{L} \\ 10 & \mu \mathrm{g} / \mathrm{L} \\ 10 & \mu \mathrm{g} / \mathrm{L} \\ 10 & \mu \mathrm{g} / \mathrm{L} \\ 10 & \mu \mathrm{g} / \mathrm{L} \\ 10 & \mu \mathrm{g} / \mathrm{L} \\ 30.4 & \mu \mathrm{g} / \mathrm{L} \\ 30.4 & \mu \mathrm{g} / \mathrm{L} \\ 10 & \mu \mathrm{g} / \mathrm{L}\end{array}$

ssMDL

3.34
3.34
3.34
3.34
3.34
3.34
3.34
3.34
3.34
1.52
3.34
3.34
3.34
3.34
3.34
3.34
3.34
3.34
3.34
3.34
3.04
3.04
3.34

ANALYTE: Europium-152

Analytical Group: Radionuclides

\begin{tabular}{|c|c|c|}
\hline Survey ID & Sample ID & $\mathbf{R Q}$ \\
\hline BG 00103 & 114003 & UI \\
\hline BG 00203 & 114004 & UI \\
\hline BG 00303 & 114005 & UI \\
\hline BG 00403 & 114010 & UI \\
\hline FMC001F03 & 114002 & UI \\
\hline FMC001H03 & 114000 & UI \\
\hline FMC002H03 & 114001 & UI \\
\hline FSP 01203 & 114019 & UI \\
\hline FSP 03203 & 114021 & UI \\
\hline FSP 03203 & 114021 & UI \\
\hline FSP 03203D & 114022 & UI \\
\hline FSP 04703 & 114020 & UI \\
\hline FSP 20403 & 114018 & UI \\
\hline FSP 29003 & 114016 & UI \\
\hline FSP 29003A & 114017 & UI \\
\hline HSP 00803 & 114006 & UI \\
\hline HSP 00803A & 114007 & UI \\
\hline HSP 02903 & 114014 & $\mathrm{UI}$ \\
\hline HSP 02903 & 114014 & UI \\
\hline HSP 04303 & 114015 & UI \\
\hline HSP 06003 & 114012 & UI \\
\hline HSP $06003 D$ & 114013 & UI \\
\hline HSP $06003 \mathrm{D}$ & 114013 & UI \\
\hline HSP 09203 & 114011 & Ul \\
\hline
\end{tabular}

\begin{tabular}{|c|c|c|c|}
\hline Regult & Unit & ssMDL & Method \\
\hline $4.25 \mathrm{E}-02$ & $\mathrm{pCi} / \mathrm{L}$ & $1.23 \mathrm{E}+01$ & EPIA-013 \\
\hline$-2.52 \mathrm{E}+00$ & $\mathrm{pCi} / \mathrm{L}$ & $1.27 \mathrm{E}+01$ & EPIA-013 \\
\hline$-4.96 \mathrm{E}+00$ & $\mathrm{pCi} / \mathrm{L}$ & $1.13 E+01$ & EPIA-013 \\
\hline $2.67 \mathrm{E}+00$ & $\mathrm{pCi} / \mathrm{L}$ & $1.83 E+01$ & EPIA-013 \\
\hline$-3.12 E+00$ & $\mathrm{pCi} / \mathrm{L}$ & $1.22 \mathrm{E}+01$ & EPIA-013 \\
\hline $6.04 \mathrm{E}-01$ & $\mathrm{pCi} / \mathrm{L}$ & $1.28 \mathrm{E}+01$ & EPIA-013 \\
\hline$-8.63 E+00$ & $\mathrm{pCi} / \mathrm{L}$ & $1.33 \mathrm{E}+01$ & EPIA-013 \\
\hline$-1.80 \mathrm{E}+00$ & $\mathrm{pCi} / \mathrm{L}$ & $8.19 E+00$ & EPIA-013 \\
\hline $2.12 \mathrm{E}-01$ & $\mathrm{pCi} / \mathrm{L}$ & $9.35 \mathrm{E}+00$ & EPIA-013 \\
\hline$-7.64 \mathrm{E}-02$ & $\mathrm{pCi} / \mathrm{L}$ & $9.78 \mathrm{E}+00$ & EPIA-013 \\
\hline $2.34 \mathrm{E}+00$ & $\mathrm{pCi} / \mathrm{L}$ & $2.56 \mathrm{E}+01$ & EPA901.1MOD \\
\hline$-5.41 E+00$ & $\mathrm{pCi} / \mathrm{L}$ & $8.45 E+00$ & EPIA-013 \\
\hline$-1.84 \mathrm{E}+00$ & $\mathrm{pCi} / \mathrm{L}$ & $8.99 E+00$ & EPIA-013 \\
\hline$-1.57 E+00$ & $\mathrm{pCi} / \mathrm{L}$ & $7.93 E+00$ & EPIA-013 \\
\hline$-2.37 \mathrm{E}+00$ & $\mathrm{pCi} / \mathrm{L}$ & $9.43 E+00$ & EPIA-013 \\
\hline$-3.38 E+00$ & $\mathrm{pCi} / \mathrm{L}$ & $9.80 \mathrm{E}+00$ & EPIA-013 \\
\hline $8.02 \mathrm{E}-01$ & $\mathrm{pCi} / \mathrm{L}$ & $1.23 E+01$ & EPIA-013 \\
\hline$-1.42 \mathrm{E}+00$ & $\mathrm{p} \mathrm{Ci} / \mathrm{L}$ & $1.23 E+01$ & EPIA-013 \\
\hline $2.04 \mathrm{E}-01$ & $\mathrm{pCi} / \mathrm{L}$ & $1.28 \mathrm{E}+01$ & EPIA-013 \\
\hline $1.85 \mathrm{E}-01$ & $\mathrm{pCi} / \mathrm{L}$ & $1.07 \mathrm{E}+01$ & EPIA-013 \\
\hline $1.84 \mathrm{E}+00$ & $\mathrm{pCi} / \mathrm{L}$ & $1.47 \mathrm{E}+01$ & EPIA-013 \\
\hline$-6.01 E+00$ & $\mathrm{pCi} / \mathrm{L}$ & $2.15 E+01$ & EPA901.1MOD \\
\hline $2.21 \mathrm{E}+01$ & $\mathrm{p} C i / L$ & $3.56 E+01$ & EPA901.1MOD \\
\hline $2.11 \mathrm{E}+00$ & $\mathrm{pCi} /$ & $1.33 \mathrm{E}+01$ & EPIA-013 \\
\hline
\end{tabular}


ANALYTE: Europium-154

Analytical Group: Radionuclides

\begin{tabular}{|c|c|c|c|c|c|c|c|}
\hline Survey ID & Sample ID & $\mathbf{R Q}$ & B & Result & Unit & ssMDL & Method \\
\hline BG 00103 & 114003 & UI & & $-2.72 \mathrm{E}-01$ & $\mathrm{pCi} / \mathrm{L}$ & $1.12 E+01$ & EPIA-013 \\
\hline BG 00203 & 114004 & UI & & $2.61 \mathrm{E}+00$ & $\mathrm{pCi} / \mathrm{L}$ & $1.46 \mathrm{E}+01$ & EPIA-013 \\
\hline BG 00303 & 114005 & UI & & $6.64 \mathrm{E}+00$ & $\mathrm{pCi} / \mathrm{L}$ & $1.48 \mathrm{E}+01$ & EPIA-013 \\
\hline BG 00403 & 114010 & UI & & $4.23 E+00$ & $\mathrm{pCi} / \mathrm{L}$ & $1.94 \mathrm{E}+01$ & EPIA-013 \\
\hline FMC001F03 & 114002 & Ul & & $5.35 \mathrm{E}+00$ & $\mathrm{pCi} / \mathrm{L}$ & $1.37 \mathrm{E}+01$ & EPIA-013 \\
\hline FMC001H03 & 114000 & $\mathrm{UI}$ & & $1.19 \mathrm{E}+00$ & $\mathrm{pCi} / \mathrm{L}$ & $1.56 \mathrm{E}+01$ & EPIA-013 \\
\hline FMCOO2H03 & 114001 & $\mathrm{UI}$ & & $-4.42 \mathrm{E}+00$ & $\mathrm{pCi} / \mathrm{h}$ & $1.58 E+01$ & EPIA-013 \\
\hline FSP 01203 & 114019 & UI & & $-9.53 \mathrm{E}-01$ & $\mathrm{pCi} / \mathrm{L}$ & $9.65 E+00$ & EPIA-013 \\
\hline FSP 03203 & 114021 & UI & & $7.38 \mathrm{E}-02$ & $\mathrm{pCi} / \mathrm{L}$ & $1.02 \mathrm{E}+01$ & EPIA-013 \\
\hline FSP 03203 & 114021 & UI & & $3.55 \mathrm{E}+00$ & $\mathrm{pCi} / \mathrm{L}$ & $1.15 \mathrm{E}+01$ & EPIA-013 \\
\hline FSP 03203D & 114022 & UI & & $-3.30 E+00$ & $\mathrm{pCi} / \mathrm{L}$ & $1.01 E+01$ & EPA901.1MOD \\
\hline FSP 04703 & 114020 & UI & & $-1.06 E+00$ & $\mathrm{pCi} / \mathrm{L}$ & $1.13 E+01$ & EPIA-013 \\
\hline FSP 20403 & 114018 & UI & & $-4.38 \mathrm{E}+00$ & $\mathrm{pCi} / \mathrm{L}$ & $7.75 E+00$ & EPIA-013 \\
\hline FSP 29003 & 114016 & UI & & $-2.06 \mathrm{E}+00$ & $\mathrm{pCi} / \mathrm{L}$ & $7.30 \mathrm{E}+00$ & EPIA-013 \\
\hline FSP 29003A & 114017 & UI & & $-3.31 \mathrm{E}-01$ & $\mathrm{pCi} / \mathrm{L}$ & $1.01 E+01$ & EPIA-013 \\
\hline HSP 00803 & 114006 & UI & & $-2.08 \mathrm{E}+00$ & $\mathrm{pCi} / \mathrm{L}$ & $1.23 E+01$ & EPIA-013 \\
\hline HSP 00803A & 114007 & UI & & $1.58 \mathrm{E}+00$ & $\mathrm{pCi} / \mathrm{L}$ & $1.39 E+01$ & EPIA-013 \\
\hline HSP 02903 & 114014 & UI & & $-5.01 E+00$ & $\mathrm{pCi} / \mathrm{L}$ & $1.21 \mathrm{E}+01$ & EPIA-013 \\
\hline HSP 02903 & 114014 & UI & & $-2.64 \mathrm{E}+00$ & $\mathrm{pCi} / \mathrm{L}$ & $1.32 \mathrm{E}+01$ & EPIA-013 \\
\hline HSP 04303 & 114015 & UI & & $-1.21 \mathrm{E}+00$ & $\mathrm{pCi} / \mathrm{L}$ & $1.22 \mathrm{E}+01$ & EPIA-013 \\
\hline HSP 06003 & 114012 & UI & & $-5.42 \mathrm{E}+00$ & $\mathrm{pCi} / \mathrm{L}$ & $1.65 \mathrm{E}+01$ & EPIA-013 \\
\hline HSP 06003D & 114013 & UI & & $2.29 \mathrm{E}+00$ & $\mathrm{pCi} / \mathrm{L}$ & $1.40 \mathrm{E}+01$ & EPA901.1MOD \\
\hline HSP 06003D & 114013 & UI & & $-1.55 \mathrm{E}+00$ & $\mathrm{pCi} / \mathrm{L}$ & $1.21 E+01$ & EPA901.1MOD \\
\hline HSP 09203 & 114011 & UI & & $9.95 \mathrm{E}-01$ & $\mathrm{pCi} / \mathrm{L}$ & $1.39 E+01$ & EPIA-013 \\
\hline
\end{tabular}

ANALYTE: Europium-155

Analytical Group: Radionuclides

$\begin{array}{llrl}\text { Survey ID } & \text { Sample ID } & \text { RQ } & \text { B } \\ \text { BG 00103 } & 114003 & \text { UI } \\ \text { BG 00203 } & 114004 & \text { UI } \\ \text { BG 00303 } & 114005 & \text { UI } \\ \text { BG 00403 } & 114010 & \text { UI } \\ \text { FMC001F03 } & 114002 & \text { UI } \\ \text { FMC001H03 } & 114000 & \text { UI } \\ \text { FMC002H03 } & 114001 & \text { UI } \\ \text { FSP 01203 } & 114019 & \text { UI } \\ \text { FSP 03203 } & 114021 & \text { UI } \\ \text { FSP 03203 } & 114021 & \text { UI } \\ \text { FSP 03203D } & 114022 & \text { UI } \\ \text { FSP 04703 } & 114020 & \text { UI } \\ \text { FSP 20403 } & 114018 & \text { UI } \\ \text { FSP 29003 } & 114016 & \text { UI } \\ \text { FSP 29003A } & 114017 & \text { UI } \\ \text { HSP 00803 } & 114006 & \text { UI } \\ \text { HSP 00803A } & 114007 & \text { UI } \\ \text { HSP 02903 } & 114014 & \text { UI } \\ \text { HSP 02903 } & 114014 & \text { UI } \\ \text { HSP 04303 } & 114015 & \text { UI } \\ \text { HSP 06003 } & 114012 & \text { UI } \\ \text { HSP 06003D } & 114013 & \text { UI }\end{array}$

\begin{tabular}{|c|c|c|c|}
\hline Result & Unit & ssMDL & Method \\
\hline $4.17 E+00$ & $\mathrm{pCi} / \mathrm{L}$ & $1.34 \mathrm{E}+01$ & EPIA-013 \\
\hline $5.32 \mathrm{E}-01$ & $\mathrm{pCi} / \mathrm{L}$ & $1.38 \mathrm{E}+01$ & EPIA-013 \\
\hline $2.28 \mathrm{E}+00$ & $\mathrm{pCi} / \mathrm{L}$ & $1.32 \mathrm{E}+01$ & EPIA-013 \\
\hline $1.77 \mathrm{E}-01$ & $\mathrm{pCi} / \mathrm{L}$ & $1.99 E+01$ & EPIA-013 \\
\hline $6.14 \mathrm{E}+00$ & $\mathrm{pCi} / \mathrm{L}$ & $1.48 \mathrm{E}+0 \mathrm{l}$ & EPIA-013 \\
\hline $5.95 E+00$ & $\mathrm{pCi} / \mathrm{L}$ & $1.53 \mathrm{E}+01$ & EPIA-013 \\
\hline $9.63 \mathrm{E}+00$ & $\mathrm{pCi} / \mathrm{L}$ & $1.58 \mathrm{E}+01$ & EPIA-013 \\
\hline$-1.57 E+00$ & $\mathrm{pCi} / \mathrm{L}$ & $1.17 \mathrm{E}+01$ & EPIA-013 \\
\hline $2.91 E-01$ & $\mathrm{pCi} / \mathrm{L}$ & $1.32 \mathrm{E}+01$ & EPIA-013 \\
\hline $2.19 \mathrm{E}+00$ & $\mathrm{pCi} / \mathrm{L}$ & $1.32 \mathrm{E}+01$ & EPIA-013 \\
\hline $3.17 \mathrm{E}+00$ & $\mathrm{pCi} / \mathrm{L}$ & $9.46 \mathrm{E}+00$ & EPA901.1MOD \\
\hline $1.71 \mathrm{E}+00$ & $\mathrm{p} \mathrm{Ci} / \mathrm{L}$ & $1.30 \mathrm{E}+01$ & EPIA-013 \\
\hline $7.17 \mathrm{E}-01$ & $\mathrm{pCi} / \mathrm{L}$ & $1.28 \mathrm{E}+01$ & EPIA-013 \\
\hline$-1.48 \mathrm{E}+00$ & $\mathrm{pCi} / \mathrm{L}$ & $1.10 \mathrm{E}+01$ & EPIA-013 \\
\hline$-3.06 E+00$ & $\mathrm{pCi} / \mathrm{L}$ & $1.21 \mathrm{E}+01$ & EPIA-013 \\
\hline $3.36 E+00$ & $\mathrm{pCi} / \mathrm{L}$ & $1.14 \mathrm{E}+01$ & EPIA-013 \\
\hline $2.36 \mathrm{E}-02$ & $\mathrm{pCi} / \mathrm{L}$ & $1.37 \mathrm{E}+01$ & EPIA-013 \\
\hline $5.90 \mathrm{E}+00$ & $\mathrm{pCi} / \mathrm{L}$ & $1.50 \mathrm{E}+01$ & EPIA-013 \\
\hline $3.53 E+00$ & $\mathrm{pCi} / \mathrm{L}$ & $1.45 \mathrm{E}+01$ & EPIA-013 \\
\hline$-4.01 \mathrm{E}-01$ & $\mathrm{p} \mathrm{Ci} / \mathrm{L}$ & $1.12 \mathrm{E}+01$ & EPIA-013 \\
\hline $1.56 \mathrm{E}+00$ & $\mathrm{pCi} / \mathrm{L}$ & $1.49 \mathrm{E}+01$ & EPIA-013 \\
\hline $7.10 \mathrm{E}-01$ & $\mathrm{pCi} / \mathrm{L}$ & $5.71 \mathrm{E}+00$ & EPA901.1MOD \\
\hline
\end{tabular}


ANALYTE: Europium-155 (cont.)

$\begin{array}{llclrlll}\text { Survey ID } & \text { Sample ID } & \text { RQ } & \text { B } & \text { Result } & \text { Unit } & \text { ssMDL } & \text { Method } \\ \text { HSP 06003D } & 114013 & \text { UI } & & 1.64 E+00 & \mathrm{pCi} / \mathrm{L} & 5.79 E+00 & \text { EPA901.1MOD } \\ \text { HSP 09203 } & 114011 & \text { UI } & 7.18 \mathrm{E}-01 & \mathrm{pCi} / \mathrm{L} & 1.43 \mathrm{E}+01 & \text { EPIA-013 }\end{array}$

ANALYTE: Gross alpha

Analytical Group: Radionuclides

\begin{tabular}{|c|c|c|c|c|c|}
\hline Survey ID & Sample ID RQ B & Result & Unit & ssMDL & Method \\
\hline BG 00103 & 114003 & $4.61 E+00$ & $\mathrm{pCi} / \mathrm{L}$ & $6.41 \mathrm{E}-01$ & EPIA-001 \\
\hline BG 00203 & 114004 & $3.13 \mathrm{E}+01$ & $\mathrm{pCi} / \mathrm{L}$ & $2.45 \mathrm{E}+00$ & EPIA-001 \\
\hline BG 00303 & 114005 & $8.28 \mathrm{E}-01$ & $\mathrm{pCi} / \mathrm{L}$ & $4.18 \mathrm{E}-01$ & EPIA-001 \\
\hline BG 00403 & 114010 & $8.69 E-01$ & $\mathrm{pCi} / \mathrm{L}$ & $4.38 \mathrm{E}-01$ & EPIA-001 \\
\hline FMC001F03 & 114002 & $2.64 \mathrm{E}+00$ & $\mathrm{pCi} / \mathrm{L}$ & $5.09 \mathrm{E}-01$ & EPIA-001 \\
\hline FMC001H03 & 114000 & $1.19 \mathrm{E}+00$ & $\mathrm{pCi} / \mathrm{L}$ & $4.59 \mathrm{E}-01$ & EPIA-001 \\
\hline FMC002H03 & 114001 & $1.53 \mathrm{E}+00$ & $\mathrm{pCi} / \mathrm{L}$ & $8.14 \mathrm{E}-01$ & EPIA-001 \\
\hline FSP 01203 & 114019 & $3.39 E+00$ & $\mathrm{pCi} / \mathrm{L}$ & $3.24 \mathrm{E}-01$ & EPIA-001 \\
\hline FSP 03203 & 114021 & $5.11 \mathrm{E}+00$ & $\mathrm{pCi} / \mathrm{L}$ & $1.23 \mathrm{E}+00$ & EPIA-001 \\
\hline FSP 03203D & 114022 & $1.14 \mathrm{E}+01$ & $\mathrm{pCi} / \mathrm{L}$ & $1.70 \mathrm{E}+00$ & EPA900.0MOD \\
\hline FSP 04703 & 114020 & $3.92 E+00$ & $\mathrm{pCi} / \mathrm{L}$ & $7.35 \mathrm{E}-01$ & EPIA-001 \\
\hline FSP 20403 & 114018 & $4.82 \mathrm{E}+01$ & $\mathrm{pCi} / \mathrm{L}$ & $1.60 \mathrm{E}+00$ & EPIA-001 \\
\hline FSP 29003 & 114016 & $4.24 \mathrm{E}+00$ & $\mathrm{pCi} / \mathrm{L}$ & $1.24 E+00$ & EPIA-001 \\
\hline FSP 29003A & 114017 & $7.33 E+00$ & $\mathrm{pCi} / \mathrm{L}$ & $8.55 \mathrm{E}-01$ & EPIA-001 \\
\hline HSP 00803 & 114006 & $2.14 \mathrm{E}+01$ & $\mathrm{pCi} / \mathrm{L}$ & $4.69 \mathrm{E}+00$ & EPIA-001 \\
\hline HSP 00803A & 114007 & $6.64 \mathrm{E}+00$ & $\mathrm{pCi} / \mathrm{L}$ & $5.60 \mathrm{E}-01$ & EPIA-001 \\
\hline HSP 02903 & 114014 & $4.23 E+01$ & $\mathrm{pCi} / \mathrm{L}$ & $5.62 \mathrm{E}-01$ & EPIA-001 \\
\hline HSP 04303 & 114015 & $2.61 E+00$ & $\mathrm{pCi} / \mathrm{L}$ & $8.11 \mathrm{E}-01$ & EPIA-001 \\
\hline HSP 06003 & 114012 & $1.27 \mathrm{E}+01$ & $\mathrm{pCi} / \mathrm{L}$ & $1.71 E+00$ & EPIA-001 \\
\hline HSP 06003D & 114013 & $5.61 \mathrm{E}+00$ & $\mathrm{pCi} / \mathrm{L}$ & $1.33 \mathrm{E}+00$ & EPA900.0MOD \\
\hline HSP 06003D & 114013 & $7.93 \mathrm{E}+00$ & $\mathrm{pCi} / \mathrm{L}$ & $1.51 \mathrm{E}+00$ & EPA900.0MOD \\
\hline HSP 09203 & 114011 & $2.50 \mathrm{E}+01$ & $\mathrm{pCi} / \mathrm{L}$ & $2.02 \mathrm{E}+00$ & EPIA-001 \\
\hline
\end{tabular}

$\mathbf{A Q}$

ANALYTE: Hardness as $\mathrm{CACO} 3$

Analytical Group: Specified Analyses

$\begin{array}{ll}\text { Survey ID } & \text { Sample ID RQ } \\ & \text { B } \\ \text { BG 00103 } & 114003 \\ \text { BG 00203 } & 114004 \\ \text { BG 00303 } & 114005 \\ \text { BG 00403 } & 114010 \\ \text { FMC001F03 } & 114002 \\ \text { FMC001H03 } & 114000 \\ \text { FMC002H03 } & 114001 \\ \text { FSP 01203 } & 114019 \\ \text { FSP 03203 } & 114021 \\ \text { FSP 03203 } & 114021 \\ \text { FSP 03203D } & 114022 \\ \text { FSP 03203D } & 114022 \\ \text { FSP 04703 } & 114020 \\ \text { FSP 20403 } & 114018 \\ \text { FSP 29003 } & 114016 \\ \text { FSP 29003A } & 114017 \\ \text { HSP 00803 } & 114006 \\ \text { HSP 00803A } & 114007\end{array}$

$\begin{array}{rlrl}\text { Result } & \text { Unit } & \text { ssMDL } & \text { Method } \\ & & & \\ 11000 & \mu \mathrm{g} / \mathrm{L} & 1000 & \mathrm{EPA130.2} \\ 16000 & \mu \mathrm{g} / \mathrm{L} & 1000 & \mathrm{EPA130.2} \\ 11700 & \mu \mathrm{g} / \mathrm{L} & 1000 & \mathrm{EPA130.2} \\ 6000 & \mu \mathrm{g} / \mathrm{L} & 1000 & \mathrm{EPA130.2} \\ 13500 & \mu \mathrm{g} / \mathrm{L} & 1000 & \mathrm{EPA} 130.2 \\ 67000 & \mu \mathrm{g} / \mathrm{L} & 1000 & \mathrm{EPA} 130.2 \\ 10000 & \mu \mathrm{g} / \mathrm{L} & 1000 & \mathrm{EPA130.2} \\ 11500 & \mu \mathrm{g} / \mathrm{L} & 1000 & \mathrm{EPA130.2} \\ 4000 & \mu \mathrm{g} / \mathrm{L} & 1000 & \mathrm{EPA130.2} \\ 4000 & \mu \mathrm{g} / \mathrm{L} & 1000 & \mathrm{EPA130.2} \\ 12000 & \mu \mathrm{g} / \mathrm{L} & 900 & \mathrm{EPA} 130.2 \\ 11500 & \mu \mathrm{g} / \mathrm{L} & 900 & \mathrm{EPA} 130.2 \\ 5000 & \mu \mathrm{g} / \mathrm{L} & 1000 & \mathrm{EPA130.2} \\ 26500 & \mu \mathrm{g} / \mathrm{L} & 1000 & \mathrm{EPA130.2} \\ 12500 & \mu \mathrm{g} / \mathrm{L} & 1000 & \mathrm{EPA130.2} \\ 6700 & \mu \mathrm{g} / \mathrm{L} & 1000 & \mathrm{EPA130.2} \\ 14000 & \mu \mathrm{g} / \mathrm{L} & 1000 & \mathrm{EPA130.2} \\ 15000 & \mu \mathrm{g} / \mathrm{L} & 1000 & \mathrm{EPA} 130.2\end{array}$


ANALYTE: Hardness as $\mathrm{CACO} 3$ (cont.)

$\begin{array}{llrrrrr}\text { Survey ID } & \text { Sample ID RQ } & \text { B } & \text { Result } & \text { Unit } & \text { ssMDL } & \text { Method } \\ \text { HSP 00803A } & 114007 & & 17000 & \mu \mathrm{g} / \mathrm{L} & 1000 & \text { EPA130.2 } \\ \text { HSP 02903 } & 114014 & 8000 & \mu \mathrm{g} / \mathrm{L} & 1000 & \text { EPA130.2 } \\ \text { HSP 02903 } & 114014 & 9600 & \mu \mathrm{g} / \mathrm{L} & 1000 & \text { EPA130.2 } \\ \text { HSP 04303 } & 114015 & 8000 & \mu \mathrm{g} / \mathrm{L} & 1000 & \text { EPA130.2 } \\ \text { HSP 06003 } & 114012 & 4000 & \mu \mathrm{g} / \mathrm{L} & 1000 & \text { EPA130.2 } \\ \text { HSP 06003D } & 114013 & 11000 & \mu \mathrm{g} / \mathrm{L} & 900 & \text { EPA130.2 } \\ \text { HSP 09203 } & 114011 & 8000 & \mu \mathrm{g} / \mathrm{L} & 1000 & \text { EPA130.2 }\end{array}$

ANALYTE: Iodine-129

Analytical Group: Radionuclides

$\begin{array}{llllllll}\text { Survey ID } & \text { Sample ID } & \text { RQ } & \text { B } & \text { Result } & \text { Unit } & \text { ssMDL } & \text { Method } \\ & & & & & & \\ \text { FSP 03203 } & 114021 & & 1.58 \mathrm{E}+00 & \mathrm{pCi} / \mathrm{L} & 1.16 \mathrm{E}+00 & \text { EPIA-006 } \\ \text { FSP 03203D } & 114022 & \text { UI } & 4.20 \mathrm{E}+00 & \mathrm{pCi} / \mathrm{L} & 1.07 \mathrm{E}+01 & \text { EPA902.0MOD } \\ \text { FSP 03203D } & 114022 & \text { UI } & 2.52 \mathrm{E}+00 & \mathrm{pCi} / \mathrm{L} & 1.02 \mathrm{E}+01 & \mathrm{EPA902.0MOD} \\ \text { FSP 20403 } & 114018 & & 3.79 \mathrm{E}+00 & \mathrm{pCi} / \mathrm{L} & 1.91 \mathrm{E}+00 & \mathrm{EPIA}-006 \\ \text { FSP 20403 } & 114018 & & 2.68 \mathrm{E}+00 & \mathrm{pCi} / \mathrm{L} & 8.79 \mathrm{E}-01 & \mathrm{EPIA}-006 \\ \text { HSP 02903 } & 114014 & \mathrm{UIJ} & 1.31 \mathrm{E}+00 & \mathrm{pCi} / \mathrm{L} & 9.10 \mathrm{E}-01 & \mathrm{EPIA}-006 \\ \text { HSP 02903 } & 114014 & \mathrm{UIJ} & 1.54 \mathrm{E}+00 & \mathrm{pCi} / \mathrm{L} & 7.59 \mathrm{E}-01 & \mathrm{EPIA}-006 \\ \text { HSP 04303 } & 114015 & \mathrm{~J} & 8.71 \mathrm{E}+00 & \mathrm{pCi} / \mathrm{L} & 6.30 \mathrm{E}-01 & \mathrm{EPIA}-006\end{array}$

AQ

C

C

ANALYTE: Iron

Analytical Group: Metals (tolal recoverable)

$\begin{array}{ll}\text { Survey ID } & \text { Sample ID RQ } \\ \text { BG 00103 } & 114003 \\ \text { BG 00203 } & 114004 \\ \text { BG 00303 } & 114005 \\ \text { BG 00403 } & 114010 \\ \text { FMC001F03 } & 114002 \\ \text { FMC001H03 } & 114000 \\ \text { FMC002H03 } & 114001 \\ \text { FSP 01203 } & 114019 \\ \text { FSP 03203 } & 114021 \\ \text { FSP 03203D } & 114022 \\ \text { FSP 04703 } & 114020 \\ \text { FSP 20403 } & 114018 \\ \text { FSP 29003 } & 114016 \\ \text { FSP 29003A } & 114017 \\ \text { HSP 00803 } & 114006 \\ \text { HSP 00803A } & 114007 \\ \text { HSP 02903 } & 114014 \\ \text { HSP 04303 } & 114015 \\ \text { HSP 06003 } & 114012 \\ \text { HSP 06003D } & 114013 \\ \text { HSP 09203 } & 114011\end{array}$

$\begin{array}{rlrl}\text { Result } & \text { Unit } & \text { ssMDL } & \text { Method } \\ 83.8 & \mu \mathrm{g} / \mathrm{L} & 8.63 & \text { EPA6010A } \\ 2360 & \mu \mathrm{g} / \mathrm{L} & 8.63 & \text { EPA6010A } \\ 700 & \mu \mathrm{g} / \mathrm{L} & 8.63 & \text { EPA6010A } \\ 1310 & \mu \mathrm{g} / \mathrm{L} & 8.63 & \text { EPA6010A } \\ 1580 & \mu \mathrm{g} / \mathrm{L} & 8.63 & \text { EPA6010A } \\ 832 & \mu \mathrm{g} / \mathrm{L} & 8.63 & \text { EPA6010A } \\ 882 & \mu \mathrm{g} / \mathrm{L} & 8.63 & \text { EPA6010A } \\ 8430 & \mu \mathrm{g} / \mathrm{L} & 8.63 & \text { EPA6010A } \\ 217 & \mu \mathrm{g} / \mathrm{L} & 8.63 & \text { EPA6010A } \\ 623 & \mu \mathrm{g} / \mathrm{L} & 7.4 & \text { EPA6010 } \\ 3910 & \mu \mathrm{g} / \mathrm{L} & 8.63 & \text { EPA6010A } \\ 100 & \mu \mathrm{g} / \mathrm{L} & 17.3 & \text { EPA6010A } \\ 1730 & \mu \mathrm{g} / \mathrm{L} & 8.63 & \text { EPA6010A } \\ 1780 & \mu \mathrm{g} / \mathrm{L} & 8.63 & \text { EPA6010A } \\ 1630 & \mu \mathrm{g} / \mathrm{L} & 8.63 & \text { EPA6010A } \\ 1420 & \mu \mathrm{g} / \mathrm{L} & 8.63 & \text { EPA6010A } \\ 2580 & \mu \mathrm{g} / \mathrm{L} & 8.63 & \text { EPA6010A } \\ 429 & \mu \mathrm{g} / \mathrm{L} & 8.63 & \text { EPA6010A } \\ 6990 & \mu \mathrm{g} / \mathrm{L} & 8.63 & \text { EPA6010A } \\ 4560 & \mu \mathrm{g} / \mathrm{L} & 7.4 & \text { EPA6010 } \\ 1330 & \mu \mathrm{g} / \mathrm{L} & 8.63 & \text { EPA6010A }\end{array}$

$\mathbf{A Q}$

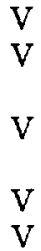


ANALYTE: Lead

Analytical Group: Metals (total recoverable)

$\begin{array}{lll}\text { Survey ID } & \text { Sample ID } & \text { RQ } \\ \text { BG 00103 } & 114003 & \\ \text { BG 00203 } & 114004 & \\ \text { BG 00303 } & 114005 & \\ \text { BG 00403 } & 114010 & \\ \text { FMC001F03 } & 114002 & \\ \text { FMC001H03 } & 114000 & \\ \text { FMC002H03 } & 114001 & \\ \text { FSP 01203 } & 114019 & \\ \text { FSP 03203 } & 114021 & \\ \text { FSP 03203D } & 114022 & \\ \text { FSP 04703 } & 114020 & \\ \text { FSP 20403 } & 114018 & \\ \text { FSP 29003 } & 114016 & \\ \text { FSP 29003A } & 114017 & \\ \text { HSP 00803 } & 114006 & \\ \text { HSP 00803A } & 114007 & \\ \text { HSP 02903 } & 114014 \\ \text { HSP 04303 } & 114015 & \\ \text { HSP 06003 } & 114012 & \\ \text { HSP 06003D } & 114013 & \\ \text { HSP 09203 } & 114011 & \end{array}$

$\begin{array}{rlrl}\text { Result } & \text { Unit } & \text { ssMDL } & \text { Method } \\ & & & \\ 5 & \mu \mathrm{g} / \mathrm{L} & 0.678 & \text { EPA6010A } \\ 5 & \mu \mathrm{g} / \mathrm{L} & 0.678 & \text { EPA6010A } \\ 5 & \mu \mathrm{g} / \mathrm{L} & 0.678 & \text { EPA6010A } \\ 0.734 & \mu \mathrm{g} / \mathrm{L} & 0.678 & \text { EPA6010A } \\ 5 & \mu \mathrm{g} / \mathrm{L} & 0.678 & \text { EPA6010A } \\ 5 & \mu \mathrm{g} / \mathrm{L} & 0.678 & \text { EPA6010A } \\ 5 & \mu \mathrm{g} / \mathrm{L} & 0.678 & \text { EPA6010A } \\ 5 & \mu \mathrm{g} / \mathrm{L} & 0.678 & \text { EPA6010A } \\ 5 & \mu \mathrm{g} / \mathrm{L} & 0.678 & \text { EPA6010A } \\ 89.5 & \mu \mathrm{g} / \mathrm{L} & 4.7 & \text { EPA6010 } \\ 2.52 & \mu \mathrm{g} / \mathrm{L} & 0.678 & \text { EPA6010A } \\ 10 & \mu \mathrm{g} / \mathrm{L} & 1.36 & \text { EPA6010A } \\ 5 & \mu \mathrm{g} / \mathrm{L} & 0.678 & \text { EPA6010A } \\ 5 & \mu \mathrm{g} / \mathrm{L} & 0.678 & \text { EPA6010A } \\ 1.09 & \mu \mathrm{g} / \mathrm{L} & 0.678 & \text { EPA6010A } \\ 5 & \mu \mathrm{g} / \mathrm{L} & 0.678 & \text { EPA6010A } \\ 18.7 & \mu \mathrm{g} / \mathrm{L} & 0.678 & \text { EPA6010A } \\ 5 & \mu \mathrm{g} / \mathrm{L} & 0.678 & \text { EPA6010A } \\ 6.81 & \mu \mathrm{g} / \mathrm{L} & 0.678 & \text { EPA6010A } \\ 5.3 & \mu \mathrm{g} / \mathrm{L} & 4.7 & \text { EPA6010 } \\ 3.18 & \mu \mathrm{g} / \mathrm{L} & 0.678 & \text { EPA6010A }\end{array}$

$\mathbf{A Q}$

V

$\mathrm{E}$

E

V

V

E

ANALYTE: Lead-212

Analytical Group: Radionuclides

\begin{tabular}{|c|c|c|}
\hline Survey ID & Sample ID & $\mathbf{R Q}$ \\
\hline BG 00103 & 114003 & UI \\
\hline BG 00203 & 114004 & UI \\
\hline BG 00303 & 114005 & $\mathrm{R}$ \\
\hline BC 00403 & 114010 & $\mathbf{R}$ \\
\hline FMC001F03 & 114002 & $\mathrm{R}$ \\
\hline FMCOO1H03 & 114000 & UI \\
\hline FMC002HO3 & 114001 & UI \\
\hline FSP 01203 & 114019 & UI \\
\hline FSP 03203 & 114021 & $\mathrm{Ul}$ \\
\hline FSP 03203 & 114021 & UI \\
\hline FSP 03203D & 114022 & UI \\
\hline FSP 04703 & 114020 & \\
\hline FSP 20403 & 114018 & UI \\
\hline FSP 29003 & 114016 & UI \\
\hline FSP 29003A & 114017 & UI \\
\hline HSP 00803 & 114006 & UI \\
\hline HSP 00803A & 114007 & $\mathrm{R}$ \\
\hline HSP 02903 & 114014 & UI \\
\hline HSP 02903 & 114014 & UI \\
\hline HSP 04303 & 114015 & UI \\
\hline HSP 06003 & 114012 & UI \\
\hline HSP 06003D & 114013 & UI \\
\hline HSP 06003D & 114013 & $\mathrm{R}$ \\
\hline HSP 09203 & 114011 & UI \\
\hline
\end{tabular}

$\begin{array}{ll}\text { Unit } & \text { ssMDL } \\ & \\ \mathrm{pCi} / \mathrm{L} & 6.43 \mathrm{E}+00 \\ \mathrm{pCi} / \mathrm{L} & 8.35 \mathrm{E}+00 \\ \mathrm{pCi} / \mathrm{L} & 8.76 \mathrm{E}+00 \\ \mathrm{pCi} / \mathrm{L} & 1.31 \mathrm{E}+01 \\ \mathrm{pCi} / \mathrm{L} & 8.73 \mathrm{E}+00 \\ \mathrm{pCi} / \mathrm{L} & 8.77 \mathrm{E}+00 \\ \mathrm{pCi} / \mathrm{L} & 8.14 \mathrm{E}+00 \\ \mathrm{pCi} / \mathrm{L} & 6.29 \mathrm{E}+00 \\ \mathrm{pCi} / \mathrm{L} & 6.80 \mathrm{E}+00 \\ \mathrm{pCi} / \mathrm{L} & 5.45 \mathrm{E}+00 \\ \mathrm{pCi} / \mathrm{L} & 5.01 \mathrm{E}+00 \\ \mathrm{pCi} / \mathrm{L} & 5.31 \mathrm{E}+00 \\ \mathrm{pCi} / \mathrm{L} & 6.27 \mathrm{E}+00 \\ \mathrm{pCi} / \mathrm{L} & 5.49 \mathrm{E}+00 \\ \mathrm{pCi} / \mathrm{L} & 6.74 \mathrm{E}+00 \\ \mathrm{pCi} / \mathrm{L} & 6.23 \mathrm{E}+00 \\ \mathrm{pCi} / \mathrm{L} & 9.00 \mathrm{E}+00 \\ \mathrm{pCi} / \mathrm{L} & 9.10 \mathrm{E}+00 \\ \mathrm{pCi} / \mathrm{L} & 8.71 \mathrm{E}+00 \\ \mathrm{pCi} / \mathrm{L} & 7.89 \mathrm{E}+00 \\ \mathrm{pCi} / \mathrm{L} & 9.59 \mathrm{E}+00 \\ \mathrm{pCi} / \mathrm{L} & 5.11 \mathrm{E}+00 \\ \mathrm{pCi} / \mathrm{L} & 4.72 \mathrm{E}+00 \\ \mathrm{pCi} / \mathrm{L} & 8.66 \mathrm{E}+00\end{array}$

Method
EPIA-013
EPIA-013
EPIA-013
EPIA-013
EPIA-013
EPIA-013
EPIA-013
EPIA-013
EPIA-013
EPIA-013
EPA901.1MOD
EPIA-013
EPIA-013
EPIA-013
EPIA-013
EPIA-013
EPIA-013
EPIA-013
EPIA-013
EPIA-013
EPIA-013
EPA901.1MOD
EPA901.1MOD
EPIA-013

$\mathbf{A Q}$

Data Summary Report for the Annual Fourmile Branch and

F- and H-Area Seeplines, Appendix IX Metals and Radionuclides, 1998

(WSRC-TR-98-00260) 
ANALYTE: Magnesium

Analytical Group: Metals (total recoverable)

$\begin{array}{ll}\text { Survey ID } & \text { Sample ID RQ } \\ & \text { B } \\ \text { BG 00103 } & 114003 \\ \text { BG 00203 } & 114004 \\ \text { BG 00303 } & 114005 \\ \text { BG 00403 } & 114010 \\ \text { FMC001F03 } & 114002 \\ \text { FMC001H03 } & 114000 \\ \text { FMC002H03 } & 114001 \\ \text { FSP 01203 } & 114019 \\ \text { FSP 03203 } & 114021 \\ \text { FSP 03203D } & 114022 \\ \text { FSP 04703 } & 114020 \\ \text { FSP 20403 } & 114018 \\ \text { FSP 29003 } & 114016 \\ \text { FSP 29003A } & 114017 \\ \text { HSP 00803 } & 114006 \\ \text { HSP 00803A } & 114007 \\ \text { HSP 02903 } & 114014 \\ \text { HSP 04303 } & 114015 \\ \text { HSP 06003 } & 114012 \\ \text { HSP 06003D } & 114013 \\ \text { HSP 09203 } & 114011\end{array}$

$\begin{array}{rlrl}\text { Result } & \text { Unit } & \text { ssMDL } & \text { Method } \\ & & & \\ 288 & \mu \mathrm{g} / \mathrm{L} & 3.33 & \text { EPA6010A } \\ 394 & \mu \mathrm{g} / \mathrm{L} & 3.33 & \text { EPA6010A } \\ 445 & \mu \mathrm{g} / \mathrm{L} & 3.33 & \text { EPA6010A } \\ 458 & \mu \mathrm{g} / \mathrm{L} & 3.33 & \text { EPA6010A } \\ 570 & \mu \mathrm{g} / \mathrm{L} & 3.33 & \text { EPA6010A } \\ 452 & \mu \mathrm{g} / \mathrm{L} & 3.33 & \text { EPA6010A } \\ 483 & \mu \mathrm{g} / \mathrm{L} & 3.33 & \text { EPA6010A } \\ 1090 & \mu \mathrm{g} / \mathrm{L} & 3.33 & \text { EPA6010A } \\ 348 & \mu \mathrm{g} / \mathrm{L} & 3.33 & \text { EPA6010A } \\ 422 & \mu \mathrm{g} / \mathrm{L} & 7.4 & \text { EPA6010 } \\ 586 & \mu \mathrm{g} / \mathrm{L} & 3.33 & \text { EPA6010A } \\ 2640 & \mu \mathrm{g} / \mathrm{L} & 6.66 & \text { EPA6010A } \\ 420 & \mu \mathrm{g} / \mathrm{L} & 3.33 & \text { EPA6010A } \\ 400 & \mu \mathrm{g} / & 3.33 & \text { EPA6010A } \\ 814 & \mu \mathrm{g} / \mathrm{L} & 3.33 & \text { EPA6010A } \\ 805 & \mu \mathrm{g} / \mathrm{L} & 3.33 & \text { EPA6010A } \\ 1100 & \mu \mathrm{g} / \mathrm{L} & 3.33 & \text { EPA6010A } \\ 778 & \mu \mathrm{g} / \mathrm{L} & 3.33 & \text { EPA6010A } \\ \mathbf{4 4 5} & \mu \mathrm{g} / \mathrm{L} & 3.33 & \text { EPA6010A } \\ 348 & \mu \mathrm{g} / \mathrm{L} & 7.4 & \text { EPA6010 } \\ \mathbf{7 7 3} & \mu \mathrm{g} / \mathrm{L} & 3.33 & \text { EPA6010A }\end{array}$

AQ

$\mathrm{V}$

$\mathrm{V}$

V

$\mathrm{V}$

$\mathrm{V}$

$\mathrm{V}$

$\mathrm{V}$

V

V

V

V

V

ANALYTE: Manganese

Analytical Group: Metals (lotal recoverable)

$\begin{array}{lll}\text { Survey ID } & \text { Sample ID RQ } & \text { B } \\ \text { BG 00103 } & 114003 \\ \text { BG 00203 } & 114004 \\ \text { BG 00303 } & 114005 \\ \text { BG 00403 } & 114010 \\ \text { FMC001F03 } & 114002 \\ \text { FMC001H03 } & 114000 \\ \text { FMC002H03 } & 114001 \\ \text { FSP 01203 } & 114019 \\ \text { FSP 03203 } & 114021 \\ \text { FSP 03203D } & 114022 \\ \text { FSP 04703 } & 114020 \\ \text { FSP 20403 } & 114018 \\ \text { FSP 29003 } & 114016 \\ \text { FSP 29003A } & 114017 \\ \text { HSP 00803 } & 114006 \\ \text { HSP 00803A } & 114007 \\ \text { HSP 02903 } & 114014 \\ \text { HSP 04303 } & 114015 \\ \text { HSP 06003 } & 114012 \\ \text { HSP 06003D } & 114013 \\ \text { HSP 09203 } & 114011\end{array}$

$\begin{array}{rlrl}\text { Result } & \text { Unit } & \text { ssMDL } & \text { Method } \\ 32.4 & \mu \mathrm{g} / \mathrm{L} & 0.903 & \text { EPA6010A } \\ 19.8 & \mu \mathrm{g} / \mathrm{L} & 0.903 & \text { EPA6010A } \\ 97.2 & \mu \mathrm{g} / \mathrm{L} & 0.903 & \text { EPA6010A } \\ 76.8 & \mu \mathrm{g} / \mathrm{L} & 0.903 & \text { EPA6010A } \\ 147 & \mu \mathrm{g} / \mathrm{L} & 0.903 & \text { EPA6010A } \\ 80.6 & \mu \mathrm{g} / \mathrm{L} & 0.903 & \text { EPA6010A } \\ 31.9 & \mu \mathrm{g} / \mathrm{L} & 0.903 & \text { EPA6010A } \\ 1020 & \mu \mathrm{g} / \mathrm{L} & 0.903 & \text { EPA6010A } \\ 357 & \mu \mathrm{g} / \mathrm{L} & 0.903 & \text { EPA6010A } \\ 454 & \mu \mathrm{g} / \mathrm{L} & 0.78 & \text { EPA6010 } \\ 220 & \mu \mathrm{g} / \mathrm{L} & 0.903 & \text { EPA6010A } \\ 940 & \mu \mathrm{g} / \mathrm{L} & 1.81 & \text { EPA6010A } \\ 65.1 & \mu \mathrm{g} / \mathrm{L} & 0.903 & \text { EPA6010A } \\ 65.3 & \mu \mathrm{g} / \mathrm{L} & 0.903 & \text { EPA6010A } \\ 71.3 & \mu \mathrm{g} / \mathrm{L} & 0.903 & \text { EPA6010A } \\ 70.5 & \mu \mathrm{g} / \mathrm{L} & 0.903 & \text { EPA6010A } \\ 1140 & \mu \mathrm{g} / \mathrm{L} & 0.903 & \text { EPA6010A } \\ 19.4 & \mu \mathrm{g} / \mathrm{L} & 0.903 & \text { EPA6010A } \\ 195 & \mu \mathrm{g} / \mathrm{L} & 0.903 & \text { EPA6010A } \\ 114 & \mu \mathrm{g} / \mathrm{L} & 0.78 & \text { EPA6010 } \\ 111 & \mu \mathrm{g} / \mathrm{L} & 0.903 & \text { EPA6010A }\end{array}$


ANALYTE: Manganese-54

Analytical Group: Radionuclides

\begin{tabular}{|c|c|c|c|c|c|c|c|}
\hline Survey ID & Sample ID & $\mathbf{R Q}$ & B & Result & Unit & ssMDL & Method \\
\hline BG 00103 & 114003 & UI & & $5.04 \mathrm{E}-02$ & $\mathrm{pCi} / \mathrm{L}$ & $4.52 \mathrm{E}+00$ & EPIA-013 \\
\hline BG 00203 & 114004 & UI & & $1.34 \mathrm{E}-01$ & $\mathrm{pCi} / \mathrm{L}$ & $4.76 \mathrm{E}+00$ & EPIA-013 \\
\hline BG 00303 & 114005 & UI & & $1.17 \mathrm{E}+00$ & $\mathrm{pCi} / \mathrm{L}$ & $4.28 \mathrm{E}+00$ & EPIA-013 \\
\hline BG 00403 & 114010 & UI & & $-7.21 \mathrm{E}-01$ & $\mathrm{pCi} / \mathrm{L}$ & $6.65 \mathrm{E}+00$ & EPIA-013 \\
\hline FMC001F03 & 114002 & UI & & $-2.18 E+00$ & $\mathrm{pCi} / \mathrm{L}$ & $3.92 \mathrm{E}+00$ & EPIA-013 \\
\hline FMC001H03 & 114000 & UI & & $-7.88 \mathrm{E}-01$ & $\mathrm{pCi} / \mathrm{L}$ & $4.64 \mathrm{E}+00$ & EPIA-013 \\
\hline FMC002H03 & 114001 & UI & & $-3.00 \mathrm{E}+00$ & $\mathrm{pCi} / \mathrm{L}$ & $5.25 \mathrm{E}+00$ & EPIA-013 \\
\hline FSP 01203 & 114019 & UI & & $-4.59 \mathrm{E}-01$ & $\mathrm{pCi} / \mathrm{L}$ & $3.26 E+00$ & EPIA-013 \\
\hline FSP 03203 & 114021 & UI & & $-1.50 \mathrm{E}+00$ & $\mathrm{pCi} / \mathrm{L}$ & $3.61 \mathrm{E}+00$ & EPIA-013 \\
\hline FSP 03203 & 114021 & UI & & $-5.49 \mathrm{E}-01$ & $\mathrm{pCi} / \mathrm{L}$ & $3.63 E+00$ & EPIA-013 \\
\hline FSP 03203D & 114022 & UI & & $-1.48 \mathrm{E}+00$ & $\mathrm{pCi} / \mathrm{L}$ & $3.06 \mathrm{E}+00$ & EPA901.1MOD \\
\hline FSP 04703 & 114020 & UI & & $9.39 \mathrm{E}-01$ & $\mathrm{pCi} / \mathrm{L}$ & $4.03 E+00$ & EPIA-013 \\
\hline FSP 20403 & 114018 & UI & & $-2.46 \mathrm{E}-01$ & $\mathrm{pCi} / \mathrm{L}$ & $3.33 E+00$ & EPIA-013 \\
\hline FSP 29003 & 114016 & UI & & $1.45 \mathrm{E}+00$ & $\mathrm{pCi} / \mathrm{L}$ & $2.14 E+00$ & EPIA-013 \\
\hline FSP $29003 \mathrm{~A}$ & 114017 & UI & & $-1.16 E+00$ & $\mathrm{pCi} / \mathrm{L}$ & $3.06 E+00$ & EPIA-013 \\
\hline HSP 00803 & 114006 & UI & & $3.84 \mathrm{E}-01$ & $\mathrm{pCi} / \mathrm{L}$ & $3.88 E+00$ & EPIA-013 \\
\hline HSP 00803A & 114007 & UI & & $-3.08 \mathrm{E}-01$ & $\mathrm{pCi} / \mathrm{L}$ & $4.35 E+00$ & EPIA-013 \\
\hline HSP 02903 & 114014 & UI & & $-5.93 \mathrm{E}-01$ & $\mathrm{pCi} / \mathrm{L}$ & $4.80 \mathrm{E}+00$ & EPIA-013 \\
\hline HSP 02903 & 114014 & UI & & $2.44 \mathrm{E}-01$ & $\mathrm{pCi} / \mathrm{L}$ & $5.47 E+00$ & EPIA-013 \\
\hline HSP 04303 & 114015 & UI & & $-2.13 \mathrm{E}-01$ & $\mathrm{pCi} / \mathrm{L}$ & $4.03 E+00$ & EPIA-013 \\
\hline HSP 06003 & 114012 & UI & & $6.70 \mathrm{E}-01$ & $\mathrm{pCi} / \mathrm{L}$ & $5.83 E+00$ & EPIA-013 \\
\hline HSP 06003D & 114013 & UI & & $-3.60 \mathrm{E}-01$ & $\mathrm{pCi} / \mathrm{L}$ & $4.41 \mathrm{E}+00$ & EPA901.1MOD \\
\hline HSP $06003 \mathrm{D}$ & 114013 & UI & & $-1.80 \mathrm{E}-01$ & $\mathrm{pCi} / \mathrm{L}$ & $4.08 \mathrm{E}+00$ & EPA901.1MOD \\
\hline HSP 09203 & 114011 & UI & & $-8.15 \mathrm{E}-02$ & $\mathrm{pCi} / \mathrm{L}$ & $4.65 \mathrm{E}+00$ & EPIA-013 \\
\hline
\end{tabular}

AQ

ANALYTE: Mercury

Analytical Group: Metals (total recoverable)

$\begin{array}{llrrrrrr}\text { Survey ID } & \text { Sample ID RQ } & \text { B } & \text { Result } & \text { Unit } & \text { ssMDL } & \text { Method } \\ & & & 0.2 & \mu \mathrm{g} / \mathrm{L} & 0.104 & \text { EPA7470 } \\ \text { BG 00103 } & 114003 & U & 0.2 & \mu \mathrm{g} / \mathrm{L} & 0.104 & \text { EPA7470 } \\ \text { BG 00203 } & 114004 & \mathrm{U} & 0.2 & \mu \mathrm{g} / \mathrm{L} & 0.104 & \text { EPA7470 } \\ \text { BG 00303 } & 114005 & \mathrm{U} & 0.2 & \mu \mathrm{g} / \mathrm{L} & 0.104 & \text { EPA7470 } \\ \text { BG 00403 } & 114010 & \mathrm{U} & 0.2 & \mu \mathrm{g} / \mathrm{L} & 0.104 & \text { EPA7470 } \\ \text { FMC001F03 } & 114002 & \mathrm{U} & 0.2 & \mu \mathrm{g} / \mathrm{L} & 0.104 & \text { EPA7470 } \\ \text { FMC001H03 } & 114000 & \mathrm{U} & 0.2 & \mu \mathrm{g} / \mathrm{L} & 0.104 & \text { EPA7470 } \\ \text { FMC002H03 } & 114001 & \mathrm{U} & 0.2 & \mu \mathrm{g} / \mathrm{L} & 0.104 & \text { EPA7470 } \\ \text { FSP 01203 } & 114019 & \mathrm{U} & 0.2 & \mu \mathrm{g} / \mathrm{L} & 0.104 & \text { EPA7470 } \\ \text { FSP 03203 } & 114021 & \mathrm{U} & 0.7 & \mu \mathrm{g} / \mathrm{L} & 0.07 & \text { EPA7470 } \\ \text { FSP 03203D } & 114022 & \mathrm{U} & 0.2 & \mu \mathrm{g} / \mathrm{L} & 0.104 & \text { EPA7470 } \\ \text { FSP 04703 } & 114020 & \mathrm{U} & 0.2 & \mu \mathrm{g} / \mathrm{L} & 0.104 & \text { EPA7470 } \\ \text { FSP 20403 } & 114018 & \mathrm{U} & 0.2 & \mu \mathrm{g} / \mathrm{L} & 0.104 & \text { EPA7470 } \\ \text { FSP 29003 } & 114016 & \mathrm{U} & 0.2 & \mu \mathrm{g} / \mathrm{L} & 0.104 & \text { EPA7470 } \\ \text { FSP 29003A } & 114017 & \mathrm{U} & 0.2 & \mu \mathrm{g} / \mathrm{L} & 0.104 & \text { EPA7470 } \\ \text { HSP 00803 } & 114006 & \mathrm{U} & 0.2 & \mu \mathrm{g} / \mathrm{L} & 0.104 & \text { EPA7470 } \\ \text { HSP 00803A } & 114007 & \mathrm{U} & 0.2 & \mu \mathrm{g} / \mathrm{L} & 0.104 & \text { EPA7470 } \\ \text { HSP 02903 } & 114014 & \mathrm{U} & 0.2 & \mu \mathrm{g} / \mathrm{L} & 0.104 & \text { EPA7470 } \\ \text { HSP 04303 } & 114015 & \mathrm{U} & 0.111 & \mu \mathrm{g} / \mathrm{L} & 0.104 & \text { EPA7470 } \\ \text { HSP 06003 } & 114012 & \mathrm{U} & 0.7 & \mu \mathrm{g} / \mathrm{L} & 0.07 & \text { EPA7470 } \\ \text { HSP 06003D } & 114013 & \mathrm{U} & 0.7 & \mu \mathrm{g} / \mathrm{L} & 0.07 & \text { EPA7470 } \\ \text { HSP 06003D } & 114013 & \mathrm{U} & 0.2 & \mu \mathrm{g} / \mathrm{L} & 0.104 & \text { EPA7470 } \\ \text { HSP 09203 } & 114011 & \mathrm{U} & & & & \\ & & & & & \end{array}$

$\mathbf{A Q}$ 
ANALYTE: Neptunium-237

Analytical Group: Radionuclides

$\begin{array}{llllllll}\text { Survey ID } & \text { Sample ID } & \text { RQ } & \text { B } & \text { Result } & \text { Unit } & \text { ssMDL } & \text { Method } \\ \text { BG 00203 } & 114004 & \text { UI } & & -7.62 \mathrm{E}-03 & \mathrm{pCi} / \mathrm{L} & 1.49 \mathrm{E}-01 & \mathrm{EPIA}-032 \\ \text { FSP 03203 } & 114021 & \text { UI } & 3.27 \mathrm{E}-02 & \mathrm{pCi} / \mathrm{L} & 9.80 \mathrm{E}-02 & \mathrm{EPIA}-032 \\ \text { FSP 20403 } & 114018 & & & 1.46 \mathrm{E}-01 & \mathrm{pCi} / \mathrm{L} & 8.80 \mathrm{E}-02 & \mathrm{EPIA}-032 \\ \text { FSP 20403 } & 114018 & & & 9.39 \mathrm{E}-02 & \mathrm{pCi} / \mathrm{L} & 8.60 \mathrm{E}-02 & \mathrm{EPIA}-032 \\ \text { HSP 00803 } & 114006 & & & 1.21 \mathrm{E}-01 & \mathrm{pCi} / \mathrm{L} & 7.30 \mathrm{E}-02 & \mathrm{EPIA}-032 \\ \text { HSP 02903 } & 114014 & & 3.22 \mathrm{E}-01 & \mathrm{pCi} / \mathrm{L} & 1.28 \mathrm{E}-01 & \mathrm{EPIA}-032 \\ \text { HSP 09203 } & 114011 & \text { UI } & 6.50 \mathrm{E}-04 & \mathrm{pCi} / \mathrm{L} & 1.23 \mathrm{E}-01 & \mathrm{EPIA-032}\end{array}$

ANALYTE: Neptunium-239

Analytical Group: Radionuclides

\begin{tabular}{|c|c|c|c|c|c|c|c|}
\hline Survey ID & Sample ID & $\mathbf{R Q}$ & $\mathbf{B}$ & Result & Unit & ssMDL & Method \\
\hline BG 00103 & 114003 & UI & & $7.39 \mathrm{E}+00$ & $\mathrm{pCi} / \mathrm{L}$ & $2.44 \mathrm{E}+01$ & EPIA-013 \\
\hline $\mathrm{BG} \quad 00203$ & 114004 & UI & & $-6.40 \mathrm{E}+00$ & $\mathrm{pCi} / \mathrm{L}$ & $2.42 \mathrm{E}+01$ & EPIA-013 \\
\hline BG 00303 & 114005 & UI & & $-3.17 \mathrm{E}+00$ & $\mathrm{pCi} / \mathrm{L}$ & $2.30 \mathrm{E}+01$ & EPIA-013 \\
\hline BG 00403 & 114010 & UI & & $-1.89 \mathrm{E}+01$ & $\mathrm{pCi} / \mathrm{L}$ & $3.53 E+01$ & EPIA-013 \\
\hline FMC001F03 & 114002 & UI & & $-5.89 \mathrm{E}+00$ & $\mathrm{pCi} / \mathrm{L}$ & $2.50 \mathrm{E}+01$ & EPIA-013 \\
\hline FMC001H03 & 114000 & UI & & $-1.00 \mathrm{E}+00$ & $\mathrm{pCi} / \mathrm{L}$ & $2.56 \mathrm{E}+01$ & EPIA-013 \\
\hline FMC002H03 & 114001 & UI & & $2.37 \mathrm{E}+00$ & $\mathrm{pCi} / \mathrm{L}$ & $2.68 \mathrm{E}+01$ & EPIA-013 \\
\hline FSP 01203 & 114019 & UI & & $2.95 \mathrm{E}+00$ & $\mathrm{pCi} / \mathrm{L}$ & $1.95 \mathrm{E}+01$ & EPIA-013 \\
\hline FSP 03203 & 114021 & UI & & $2.52 \mathrm{E}+00$ & $\mathrm{pCi} / \mathrm{L}$ & $2.32 E+01$ & EPIA-013 \\
\hline FSP 03203 & 114021 & UI & & $4.00 \mathrm{E}+00$ & $\mathrm{pCi} / \mathrm{L}$ & $2.34 E+01$ & EPIA-013 \\
\hline FSP 04703 & 114020 & UI & & $-7.51 E+00$ & $\mathrm{pCi} / \mathrm{L}$ & $2.15 \mathrm{E}+01$ & EPIA-013 \\
\hline FSP 20403 & 114018 & UI & & $6.57 \mathrm{E}+00$ & $\mathrm{pCi} / \mathrm{L}$ & $2.25 \mathrm{E}+01$ & EPIA-013 \\
\hline FSP 29003 & 114016 & UI & & $4.84 E+00$ & $\mathrm{pCi} / \mathrm{L}$ & $1.99 \mathrm{E}+01$ & EPIA-013 \\
\hline FSP 29003A & 114017 & UI & & $-6.40 \mathrm{E}-01$ & $\mathrm{pCi} / \mathrm{L}$ & $2.22 \mathrm{E}+01$ & EPIA-013 \\
\hline HSP 00803 & 114006 & UI & & $2.84 E+00$ & $\mathrm{pCi} / \mathrm{L}$ & $1.87 \mathrm{E}+01$ & EPIA-013 \\
\hline HSP $00803 \mathrm{~A}$ & 114007 & UI & & $-2.05 E+00$ & $\mathrm{pCi} / \mathrm{L}$ & $2.36 \mathrm{E}+01$ & EPIA-013 \\
\hline HSP 02903 & 114014 & UI & & $-6.40 \mathrm{E}+00$ & $\mathrm{pCi} /$ & $2.66 \mathrm{E}+01$ & EPIA-013 \\
\hline HSP 02903 & 114014 & Ul & & $-1.71 \mathrm{E}+01$ & $\mathrm{pCi} / \mathrm{L}$ & $2.33 \mathrm{E}+01$ & EPIA-013 \\
\hline HSP 04303 & 114015 & UI & & $-1.33 E+01$ & $\mathrm{pCi} / \mathrm{L}$ & $1.97 \mathrm{E}+01$ & EPIA-013 \\
\hline HSP 06003 & 114012 & UI & & $-1.19 E+00$ & $\mathrm{pCi} / \mathrm{L}$ & $2.67 E+01$ & EPIA-013 \\
\hline HSP 09203 & 114011 & UI & & $-4.62 \mathrm{E}+00$ & $\mathrm{pCi} / \mathrm{L}$ & $2.46 \mathrm{E}+01$ & EPIA-013 \\
\hline
\end{tabular}

ANALYTE: Nickel

Analytical Group: Metals (tolal recoverable)

$\begin{array}{llrrrrrr}\text { Survey ID } & \text { Sample ID } & \text { RQ } & \text { B } & \text { Result } & \text { Unit } & \text { ssMDL } & \text { Method } \\ \text { BG 00103 } & 114003 & U & 5 & \mu g / L & 2.27 & \text { EPA6010A } \\ \text { BG 00203 } & 114004 & U & 5 & \mu g / L & 2.27 & \text { EPA6010A } \\ \text { BG 00303 } & 114005 & U & 5 & \mu g / L & 2.27 & \text { EPA6010A } \\ \text { BG 00403 } & 114010 & J & 3.36 & \mu g / L & 2.27 & \text { EPA6010A } \\ \text { FMC001F03 } & 114002 & U & 5 & \mu g / L & 2.27 & \text { EPA6010A } \\ \text { FMC001H03 } & 114000 & U & 5 & \mu g / L & 2.27 & \text { EPA6010A } \\ \text { FMC002H03 } & 114001 & U & 5 & \mu g / L & 2.27 & \text { EPA6010A } \\ \text { FSP 01203 } & 114019 & U & 5 & \mu g / L & 2.27 & \text { EPA6010A } \\ \text { FSP 03203 } & 114021 & U & 5 & \mu g / L & 2.27 & \text { EPA6010A } \\ \text { FSP 03203D } & 114022 & & 92.6 & \mu \mathrm{g} / \mathrm{L} & 2.6 & \text { EPA6010 } \\ \text { FSP 04703 } & 114020 & \mathrm{U} & 5 & \mu \mathrm{g} / \mathrm{L} & 2.27 & \text { EPA6010A } \\ \text { FSP 20403 } & 114018 & J & 9.42 & \mu \mathrm{g} / \mathrm{L} & 4.54 & \text { EPA6010A } \\ \text { FSP 29003 } & 114016 & \mathrm{U} & 5 & \mu \mathrm{g} / \mathrm{L} & 2.27 & \text { EPA6010A }\end{array}$

AQ 
ANALYTE: Nickel (cont.)

\begin{tabular}{|c|c|c|}
\hline Survey ID & Sample ID & $\mathbf{R Q}$ \\
\hline FSP $29003 \mathrm{~A}$ & 114017 & U \\
\hline HSP 00803 & 114006 & U \\
\hline HSP 00803A & 114007 & $U$ \\
\hline HSP 02903 & 114014 & \\
\hline HSP 04303 & 114015 & U \\
\hline HSP 06003 & 114012 & $J$ \\
\hline HSP 06003D & 114013 & \\
\hline HSP 09203 & 114011 & $\mathrm{~J}$ \\
\hline
\end{tabular}

\begin{tabular}{|c|c|c|c|}
\hline Result & Unit & ssMDL & Method \\
\hline 5 & $\mu g / L$ & 2.27 & EPA6010A \\
\hline 5 & $\mu \mathrm{g} / \mathrm{L}$ & 2.27 & EPA6010A \\
\hline 5 & $\mu \mathrm{g} / \mathrm{L}$ & 2.27 & EPA6010A \\
\hline 17.8 & $\mu \mathrm{g} / \mathrm{L}$ & 2.27 & EPA6010A \\
\hline 5 & $\mu \mathrm{g} / \mathrm{L}$ & 2.27 & EPA6010A \\
\hline 3.54 & $\mu g / L$ & 2.27 & EPA6010A \\
\hline 85.6 & $\mu \mathrm{g} / \mathrm{L}$ & 2.6 & EPA6010 \\
\hline & $\mu \mathrm{g} / \mathrm{L}$ & 2.27 & EPA6010A \\
\hline
\end{tabular}

AQ

E

E

ANALYTE: Nickel-63

Analytical Group: Radionuclides

\begin{tabular}{|c|c|c|}
\hline Survey ID & Sample ID & $\mathbf{R Q}$ \\
\hline FSP 03203 & 114021 & UI \\
\hline FSP 03203D & 114022 & UIJ \\
\hline FSP 03203D & 114022 & UIJ \\
\hline FSP 20403 & 114018 & UI \\
\hline HSP 02903 & 114014 & UI \\
\hline HSP 02903 & 114014 & UI \\
\hline HSP 04303 & 114015 & UI \\
\hline
\end{tabular}

$\begin{array}{rlrl}\text { Result } & \text { Unit } & \text { ssMDL } & \text { Method } \\ & & & \\ -1.23 \mathrm{E}+02 & \mathrm{pCi} / \mathrm{L} & 2.53 \mathrm{E}+02 & \text { EPIA-022 } \\ -3.04 \mathrm{E}+00 & \mathrm{pCi} / \mathrm{L} & 1.27 \mathrm{E}+01 & 3500 \mathrm{NIEMOD} \\ -5.28 \mathrm{E}+00 & \mathrm{pCi} / \mathrm{L} & 1.25 \mathrm{E}+01 & 3500 \mathrm{NIEMOD} \\ 6.53 \mathrm{E}+01 & \mathrm{pCi} / \mathrm{L} & 2.20 \mathrm{E}+02 & \text { EPIA-022 } \\ 4.07 \mathrm{E}+01 & \mathrm{pCi} / \mathrm{L} & 2.49 \mathrm{E}+02 & \text { EPIA-022 } \\ 1.96 \mathrm{E}+02 & \mathrm{pCi} / \mathrm{L} & 2.55 \mathrm{E}+02 & \text { EPIA-022 } \\ -2.82 \mathrm{E}+01 & \mathrm{pCi} / \mathrm{L} & 2.33 \mathrm{E}+02 & \text { EPIA-022 }\end{array}$

AQ

$\mathrm{C}$

$\mathrm{C}$

ANALYTE: Nitrate as nitrogen

Analytical Group: Specified Analyses

$\begin{array}{llll}\text { Survey ID } & \text { Sample ID } & \text { RQ } & \text { B } \\ \text { BG 00103 } & 114003 & & \\ \text { BG 00103 } & 114003 & & \\ \text { BG 00203 } & 114004 & & \\ \text { BG 00303 } & 114005 & & \\ \text { BG 00403 } & 114010 & & \text { L } \\ \text { FMC001F03 } & 114002 & \mathrm{~J} & \text { L } \\ \text { FMC001H03 } & 114000 & \mathrm{~J} & \text { L } \\ \text { FMC001H03 } & 114000 & \mathrm{~J} & \mathrm{~L} \\ \text { FMC002H03 } & 114001 & \mathrm{~J} & \mathrm{~L} \\ \text { FSP 01203 } & 114019 & & \\ \text { FSP 03203 } & 114021 & & \\ \text { FSP 03203D } & 114022 & \mathrm{~J} & \\ \text { FSP 04703 } & 114020 & & \\ \text { FSP 20403 } & 114018 & & \\ \text { FSP 29003 } & 114016 & & \\ \text { FSP 29003 } & 114016 & & \\ \text { FSP 29003A } & 114017 & & \\ \text { HSP 00803 } & 114006 & & \\ \text { HSP 00803A } & 114007 & & \\ \text { HSP 02903 } & 114014 & & \\ \text { HSP 04303 } & 114015 & & \\ \text { HSP 06003 } & 114012 & & \\ \text { HSP 06003 } & 114012 & & \\ \text { HSP 06003D } & 114013 & \mathrm{~J} & \\ \text { HSP 09203 } & 114011 & & \end{array}$

$\begin{array}{rlrl}\text { Result } & \text { Unit } & \text { ssMDL } & \text { Method } \\ & & 6 & \\ 302 & \mu \mathrm{g} / \mathrm{L} & 6 & \text { EPA300.0 } \\ 309 & \mu \mathrm{g} / \mathrm{L} & 6 & \text { EPA300.0 } \\ 102 & \mu \mathrm{g} / \mathrm{L} & 6 & \text { EPA300.0 } \\ 122 & \mu \mathrm{g} / \mathrm{L} & 6 & \text { EPA300.0 } \\ 126 & \mu \mathrm{g} / \mathrm{L} & 6 & \text { EPA300.0 } \\ 919 & \mu \mathrm{g} / \mathrm{L} & 6 & \text { EPA300.0 } \\ 807 & \mu \mathrm{g} / \mathrm{L} & 6 & \text { EPA300.0 } \\ 852 & \mu \mathrm{g} / \mathrm{L} & 6 & \text { EPA300.0 } \\ 163 & \mu \mathrm{g} / \mathrm{L} & 6 & \text { EPA300.0 } \\ 237 & \mu \mathrm{g} / \mathrm{L} & 6 & \text { EPA300.0 } \\ 1250 & \mu \mathrm{g} / \mathrm{L} & 6 & \text { EPA300.0 } \\ 1760 & \mu \mathrm{g} / \mathrm{L} & 20 & \text { EPA353.2 } \\ 440 & \mu \mathrm{g} / \mathrm{L} & 6 & \text { EPA300.0 } \\ 34200 & \mu \mathrm{g} / \mathrm{L} & 600 & \text { EPA300.0 } \\ 206 & \mu \mathrm{g} / \mathrm{L} & 6 & \text { EPA300.0 } \\ 208 & \mu \mathrm{g} / \mathrm{L} & 6 & \text { EPA300.0 } \\ 266 & \mu \mathrm{g} / \mathrm{L} & 6 & \text { EPA300.0 } \\ 2030 & \mu \mathrm{g} / \mathrm{L} & 6 & \text { EPA300.0 } \\ 2090 & \mu \mathrm{g} / \mathrm{L} & 6 & \text { EPA300.0 } \\ 994 & \mu \mathrm{g} / \mathrm{L} & 6 & \text { EPA300.0 } \\ 2700 & \mu \mathrm{g} / \mathrm{L} & 6 & \text { EPA300.0 } \\ 325 & \mu \mathrm{g} / \mathrm{L} & 6 & \text { EPA300.0 } \\ 301 & \mu \mathrm{g} / \mathrm{L} & 6 & \text { EPA300.0 } \\ 143 & \mu \mathrm{g} / \mathrm{L} & 2 & \text { EPA353.2 } \\ 1190 & \mu \mathrm{g} / \mathrm{L} & 6 & \text { EPA300.0 }\end{array}$

AQ

V
V
V
V
V
Q
Q
Q
Q
V
V
Q
V
V
V
V
V
V
V
V
V
V
V
Q
V

Data Summary Report for the Annual Fourmile Branch and

F- and H-Area Seeplines, Appendix IX Metals and Radionuclides, 1998

(WSRC-TR-98-00260) 
ANALYTE: Nitrate-nitrite as nitrogen

Analytical Group: Specified Analyses

\begin{tabular}{|c|c|c|}
\hline Survey ID & Sample ID & $\mathbf{R Q}$ \\
\hline BG 00103 & 114003 & \\
\hline $\mathrm{BG} \quad 00203$ & 114004 & \\
\hline BG 00303 & 114005 & \\
\hline BG 00403 & 114010 & \\
\hline FMC001F03 & 114002 & \\
\hline FMC001H03 & 114000 & \\
\hline EMC002H03 & 114001 & \\
\hline FSP 01203 & 114019 & \\
\hline FSP 03203 & 114021 & \\
\hline FSP 03203D & 114022 & \\
\hline FSP 04703 & 114020 & \\
\hline FSP 20403 & 114018 & \\
\hline FSP 29003 & 114016 & \\
\hline FSP 29003A & 114017 & \\
\hline HSP 00803 & 114006 & \\
\hline HSP $00803 \mathrm{~A}$ & 114007 & \\
\hline HSP 02903 & 114014 & \\
\hline HSP 04303 & 114015 & \\
\hline HSP 06003 & 114012 & \\
\hline HSP 06003D & 114013 & $\mathrm{~J}$ \\
\hline HSP 09203 & 114011 & \\
\hline HSP 09203 & 114011 & \\
\hline
\end{tabular}

$\begin{array}{rlrl}\text { Result } & \text { Unit } & \text { ssMDL } & \text { Method } \\ 320 & \mu \mathrm{g} / \mathrm{L} & 7 & \text { EPA353.1 } \\ 210 & \mu \mathrm{g} / \mathrm{L} & 7 & \text { EPA353.1 } \\ 90 & \mu \mathrm{g} / \mathrm{L} & 7 & \text { EPA353.1 } \\ 200 & \mu \mathrm{g} / \mathrm{L} & 7 & \text { EPA353.1 } \\ 1020 & \mu \mathrm{g} / \mathrm{L} & 7 & \text { EPA353.1 } \\ 80 & \mu \mathrm{g} / \mathrm{L} & 7 & \text { EPA353.1 } \\ 170 & \mu \mathrm{g} / \mathrm{L} & 7 & \text { EPA353.1 } \\ 11400 & \mu \mathrm{g} / \mathrm{L} & 35 & \text { EPA353.1 } \\ 1470 & \mu \mathrm{g} / \mathrm{L} & 7 & \text { EPA353.1 } \\ 1500 & \mu \mathrm{g} / \mathrm{L} & 20 & \text { EPA353.2 } \\ 500 & \mu \mathrm{g} / \mathrm{L} & 7 & \text { EPA353.1 } \\ 35800 & \mu \mathrm{g} / \mathrm{L} & 175 & \text { EPA353.1 } \\ 280 & \mu \mathrm{g} / \mathrm{L} & 7 & \text { EPA353.1 } \\ 400 & \mu \mathrm{g} / \mathrm{L} & 7 & \text { EPA353.1 } \\ 2430 & \mu \mathrm{g} / \mathrm{L} & 7 & \text { EPA353.1 } \\ 2790 & \mu \mathrm{g} / \mathrm{L} & 7 & \text { EPA353.1 } \\ 1010 & \mu \mathrm{g} / \mathrm{L} & 7 & \text { EPA353.1 } \\ 2480 & \mu \mathrm{g} / \mathrm{L} & 7 & \text { EPA353.1 } \\ 560 & \mu \mathrm{g} / \mathrm{L} & 7 & \text { EPA353.1 } \\ 31 & \mu \mathrm{g} / \mathrm{L} & 4 & \text { EPA353.2 } \\ 1180 & \mu \mathrm{g} / \mathrm{L} & 7 & \text { EPA353.1 } \\ 1170 & \mu \mathrm{g} / \mathrm{L} & 7 & \text { EPA353.1 }\end{array}$

$\mathbf{A Q}$

V

V

V

$\mathrm{V}$

V

E

ANALYTE: Nonvolatile beta

Analytical Group: Radionuclides

\begin{tabular}{|c|c|c|}
\hline Survey ID & Sample ID & $\mathbf{R Q}$ \\
\hline BG 00103 & 114003 & \\
\hline BG 00203 & 114004 & \\
\hline $\mathrm{BG} \quad 00303$ & 114005 & UI \\
\hline $\mathrm{BG} \quad 00403$ & 114010 & \\
\hline FMC001F03 & 114002 & \\
\hline FMCOOLHO3 & 114000 & \\
\hline FMC002H03 & 114001 & \\
\hline FSP 01203 & 114019 & \\
\hline FSP 03203 & 114021 & \\
\hline FSP 03203D & 114022 & \\
\hline FSP 04703 & 114020 & \\
\hline FSP 20403 & 114018 & \\
\hline FSP 29003 & 114016 & \\
\hline FSP 29003A & 114017 & \\
\hline HSP 00803 & 114006 & \\
\hline HSP $00803 A$ & 114007 & \\
\hline HSP 02903 & 114014 & \\
\hline HSP 04303 & 114015 & \\
\hline HSP 06003 & 114012 & \\
\hline HSP 06003D & 114013 & $\mathrm{~J}$ \\
\hline HSP 06003D & 114013 & $J$ \\
\hline HSP 09203 & 114011 & \\
\hline
\end{tabular}

Result
$4.43 \mathrm{E}+00$
$1.79 \mathrm{E}+01$
$1.12 \mathrm{E}+00$
$1.01 \mathrm{E}+00$
$1.74 \mathrm{E}+01$
$3.58 \mathrm{E}+00$
$8.88 \mathrm{E}+00$
$2.94 \mathrm{E}+01$
$7.30 \mathrm{E}+01$
$7.95 \mathrm{E}+01$
$3.25 \mathrm{E}+01$
$4.82 \mathrm{E}+02$
$7.61 \mathrm{E}+00$
$8.59 \mathrm{E}+00$
$3.77 \mathrm{E}+01$
$6.45 \mathrm{E}+00$
$3.32 \mathrm{E}+02$
$2.33 \mathrm{E}+02$
$3.61 \mathrm{E}+01$
$2.67 \mathrm{E}+01$
$3.48 \mathrm{E}+01$
$1.62 \mathrm{E}+01$$$
\text { Uni }
$$$$
\text { ssMDI }
$$

$\mathrm{pCi} / \mathrm{L} \quad 1.13 \mathrm{E}+00$ $\mathrm{pCi} / \mathrm{L} \quad 2.88 \mathrm{E}+00$ $\mathrm{pCi} / \mathrm{L} \quad 1.13 \mathrm{E}+00$ $\mathrm{pCi} / \mathrm{L} \quad 9.40 \mathrm{E}-01$ $\mathrm{pCi} / \mathrm{L} \quad 1.20 \mathrm{E}+00$ $\mathrm{pCi} / \mathrm{L} \quad 1.06 \mathrm{E}+00$ $\mathrm{pCi} / \mathrm{L} \quad 1.40 \mathrm{E}+00$ $\mathrm{pCi} / \mathrm{L} \quad 2.03 \mathrm{E}+00$ $\mathrm{pCi} / \mathrm{L} \quad 2.05 \mathrm{E}+00$ $\mathrm{pCi} / \mathrm{L} \quad 2.61 \mathrm{E}+00$ $\mathrm{pCi} / \mathrm{L} \quad 1.97 \mathrm{E}+00$ p Ci/L $2.21 \mathrm{E}+00$ $\mathrm{pCi} / \mathrm{L} \quad 2.16 \mathrm{E}+00$ $\mathrm{pCi} / \mathrm{L} \quad 2.07 \mathrm{E}+00$ $\mathrm{pCi} / \mathrm{L} \quad 4.81 \mathrm{E}+00$ $\mathrm{pCi} / \mathrm{L} \quad 8.36 \mathrm{E}-01$ $\mathrm{pCi} / \mathrm{L} \quad 9.36 \mathrm{E}-01$ $\mathrm{pCi} / \mathrm{L} \quad 1.25 \mathrm{E}+00$ $\mathrm{pCi} / \mathrm{L} \quad 2.13 \mathrm{E}+00$ pCi/L $1.88 \mathrm{E}+00$ $\mathrm{pCi} / \quad 1.92 \mathrm{E}+00$ $\mathrm{pCi} / \mathrm{L} \quad 2.48 \mathrm{E}+00$
Method

EPIA-001

EPIA-001

EPIA-001

EPIA-001

EPIA-001

EPIA-001

EPIA-001

EPIA-001

EPIA-001

EPA900.0MOD

EPLA-001

EPIA-001

EPIA-001

EPIA-001

EPIA-001

EPIA-001

EPIA-001

EPIA-001

EPIA-001

EPA900.0MOD

EPA900.0MOD

EPIA-001
AQ

X

$\mathrm{X}$
$\mathrm{X}$

Data Summary Report for the Annual Fourmile Branch and

F- and H-Area Seeplines, Appendix IX Metals and Radionuclides, 1998

(WSRC-TR-98-00260) 
ANALYTE: Potassium

Analytical Group: Metals (total recoverable)

$\begin{array}{llcl}\text { Survey ID } & \text { Sample ID } & \text { RQ } & \text { B } \\ \text { BG 00103 } & 114003 & \mathrm{~J} \\ \text { BG 00203 } & 114004 & \mathrm{~J} & \\ \text { BG 00303 } & 114005 & \\ \text { BG 00403 } & 114010 & \\ \text { FMC001F03 } & 114002 & \\ \text { FMC001H03 } & 114000 & \\ \text { FMC002H03 } & 114001 & \\ \text { FSP 01203 } & 114019 & \\ \text { FSP 03203 } & 114021 & \\ \text { FSP 03203D } & 114022 & \mathrm{~J} \\ \text { FSP 04703 } & 114020 & \mathrm{~J} \\ \text { FSP 20403 } & 114018 & \\ \text { FSP 29003 } & 114016 & \\ \text { FSP 29003A } & 114017 & \\ \text { HSP 00803 } & 114006 & \\ \text { HSP 00803A } & 114007 & \\ \text { HSP 02903 } & 114014 & \\ \text { HSP 04303 } & 114015 & \\ \text { HSP 06003 } & 114012 & \\ \text { HSP 06003D } & 114013 & \\ \text { HSP 09203 } & 114011 & \end{array}$

$\begin{array}{rlrl}\text { Result } & \text { Unit } & \text { ssMDL } & \text { Method } \\ & & & \\ 95.3 & \mu \mathrm{g} / \mathrm{L} & 5.87 & \text { EPA6010A } \\ 69.9 & \mu \mathrm{g} / \mathrm{L} & 5.87 & \text { EPA6010A } \\ 146 & \mu \mathrm{g} / \mathrm{L} & 5.87 & \text { EPA6010A } \\ 273 & \mu \mathrm{g} / \mathrm{L} & 5.87 & \text { EPA6010A } \\ 409 & \mu \mathrm{g} / \mathrm{L} & 5.87 & \text { EPA6010A } \\ 297 & \mu \mathrm{g} / \mathrm{L} & 5.87 & \text { EPA6010A } \\ 316 & \mu \mathrm{g} / \mathrm{L} & 5.87 & \text { EPA6010A } \\ 880 & \mu \mathrm{g} / \mathrm{L} & 5.87 & \text { EPA6010A } \\ 128 & \mu \mathrm{g} / \mathrm{L} & 5.87 & \text { EPA6010A } \\ 141 & \mu \mathrm{g} / \mathrm{L} & 18.7 & \text { EPA6010 } \\ 37.8 & \mu \mathrm{g} / \mathrm{L} & 5.87 & \text { EPA6010A } \\ 405 & \mu \mathrm{g} / \mathrm{L} & 11.7 & \text { EPA6010A } \\ 114 & \mu \mathrm{g} / \mathrm{L} & 5.87 & \text { EPA6010A } \\ 131 & \mu \mathrm{g} / \mathrm{L} & 5.87 & \text { EPA6010A } \\ 169 & \mu \mathrm{g} / \mathrm{L} & 5.87 & \text { EPA6010A } \\ 151 & \mu \mathrm{g} / \mathrm{L} & 5.87 & \text { EPA6010A } \\ 457 & \mu \mathrm{g} / \mathrm{L} & 5.87 & \text { EPA6010A } \\ 766 & \mu \mathrm{g} / \mathrm{L} & 5.87 & \text { EPA6010A } \\ 347 & \mu \mathrm{g} / \mathrm{L} & 5.87 & \text { EPA6010A } \\ 296 & \mu \mathrm{g} / \mathrm{L} & 18.7 & \text { EPA6010 } \\ 164 & \mu \mathrm{g} / \mathrm{L} & 5.87 & \text { EPA6010A }\end{array}$

$\mathbf{A Q}$

$\mathrm{E}$

ANALYTE: Potassium-40

Analytical Group: Radionuclides

\begin{tabular}{|c|c|c|}
\hline Survey ID & Sample ID & $\mathbf{R Q}$ \\
\hline BG 00103 & 114003 & UI \\
\hline BG 00203 & 114004 & UI \\
\hline BG 00303 & 114005 & UI \\
\hline BG 00403 & 114010 & \\
\hline FMC001F03 & 114002 & UI \\
\hline FMCOO1H03 & 114000 & UI \\
\hline $\mathrm{FMC0O2H03}$ & 114001 & UI \\
\hline FSP 01203 & 114019 & \\
\hline FSP 03203 & 114021 & UI \\
\hline FSP 03203 & 114021 & UI \\
\hline FSP 03203D & 114022 & UI \\
\hline FSP 04703 & 114020 & UI \\
\hline FSP 20403 & 114018 & UI \\
\hline FSP 29003 & 114016 & UI \\
\hline FSP 29003A & 114017 & UI \\
\hline HSP 00803 & 114006 & UI \\
\hline HSP $00803 \mathrm{~A}$ & 114007 & UI \\
\hline HSP 02903 & 114014 & UI \\
\hline HSP 02903 & 114014 & UI \\
\hline HSP 04303 & 114015 & UI \\
\hline HSP 06003 & 114012 & UI \\
\hline HSP 06003D & 114013 & UI \\
\hline HSP 06003D & 114013 & $\mathrm{R}$ \\
\hline HSP 09203 & 114011 & UI \\
\hline
\end{tabular}

\begin{tabular}{|c|c|c|c|}
\hline Result & Unit & ssMDL & Method \\
\hline $8.24 E+00$ & $\mathrm{pCi} / \mathrm{L}$ & $4.21 \mathrm{E}+01$ & EPIA-013 \\
\hline 8.87E-01 & $\mathrm{pCi} / \mathrm{L}$ & $4.34 \mathrm{E}+01$ & EPIA-013 \\
\hline $4.91 E+01$ & $\mathrm{pCi} / \mathrm{L}$ & $6.86 \mathrm{E}+01$ & EPIA-013 \\
\hline $8.89 E+01$ & $\mathrm{pCi} / \mathrm{L}$ & $7.36 \mathrm{E}+01$ & EPIA-013 \\
\hline $2.81 \mathrm{E}+00$ & $\mathrm{pCi} / \mathrm{L}$ & $5.06 \mathrm{E}+01$ & EPIA-013 \\
\hline $6.80 \mathrm{E}+01$ & $\mathrm{pCi} / \mathrm{L}$ & $7.51 \mathrm{E}+01$ & EPIA-013 \\
\hline $6.57 \mathrm{E}+01$ & $\mathrm{pCi} / \mathrm{L}$ & $4.61 \mathrm{E}+01$ & EPIA-013 \\
\hline $6.47 \mathrm{E}+01$ & $\mathrm{pCi} / \mathrm{L}$ & $2.68 \mathrm{E}+01$ & EPIA-013 \\
\hline $3.02 E+01$ & $\mathrm{pCi} / \mathrm{L}$ & $4.96 E+01$ & EPIA-013 \\
\hline $3.16 E+01$ & $\mathrm{pCi} / \mathrm{L}$ & $4.80 E+01$ & EPIA-013 \\
\hline $9.69 E+00$ & $\mathrm{pCi} / \mathrm{L}$ & $3.80 \mathrm{E}+01$ & EPA901.1MOD \\
\hline $2.93 E+01$ & $\mathrm{pCi} / \mathrm{L}$ & $4.92 \mathrm{E}+01$ & EPIA-013 \\
\hline $1.58 \mathrm{E}+01$ & $\mathrm{pCi} / \mathrm{L}$ & $4.17 \mathrm{E}+01$ & EPIA-013 \\
\hline $2.40 \mathrm{E}+01$ & $\mathrm{pCi} / \mathrm{L}$ & $2.34 \mathrm{E}+01$ & EPIA-013 \\
\hline $3.00 E+01$ & $\mathrm{pCi} / \mathrm{L}$ & $4.94 \mathrm{E}+01$ & EPIA-013 \\
\hline $5.77 \mathrm{E}-01$ & $\mathrm{pCi} / \mathrm{L}$ & $4.42 \mathrm{E}+01$ & EPIA-013 \\
\hline $2.49 \mathrm{E}+01$ & $\mathrm{pCi} / \mathrm{L}$ & $4.87 \mathrm{E}+01$ & EPIA-013 \\
\hline $4.66 \mathrm{E}+01$ & $\mathrm{pCi} / \mathrm{L}$ & $4.64 E+01$ & EPIA-013 \\
\hline $4.53 \mathrm{E}+01$ & $\mathrm{pCi} / \mathrm{L}$ & $6.88 \mathrm{E}+01$ & EPIA-013 \\
\hline $2.74 \mathrm{E}+01$ & $\mathrm{pCi} / \mathrm{L}$ & $5.90 \mathrm{E}+01$ & EPIA-013 \\
\hline $8.29 E+01$ & $\mathrm{pCi} / \mathrm{L}$ & $8.45 E+01$ & EPIA-013 \\
\hline $1.63 E+01$ & $\mathrm{pCi} / \mathrm{L}$ & $3.94 \mathrm{E}+01$ & EPA901.1MOD \\
\hline $7.22 \mathrm{E}+00$ & $\mathrm{pCi} / \mathrm{L}$ & $3.44 E+01$ & EPA901.1MOD \\
\hline $1.56 \mathrm{E}+01$ & $\mathrm{pCi} / \mathrm{L}$ & $4.79 \mathrm{E}+01$ & EPIA-013 \\
\hline
\end{tabular}


ANALYTE: Promethium-144

Analytical Group: Radionuclides

$\begin{array}{llr}\text { Survey ID } & \text { Sample ID } & \text { RQ } \\ \text { BG 00103 } & 114003 & \text { UI } \\ \text { BG 00203 } & 114004 & \text { UI } \\ \text { BG 00303 } & 114005 & \text { UI } \\ \text { BG 00403 } & 114010 & \text { UI } \\ \text { FMC001F03 } & 114002 & \text { UI } \\ \text { FMC001H03 } & 114000 & \text { UI } \\ \text { FMC002H03 } & 114001 & \text { UI } \\ \text { FSP 01203 } & 114019 & \text { UI } \\ \text { FSP 03203 } & 114021 & \text { UI } \\ \text { FSP 03203 } & 114021 & \text { UI } \\ \text { FSP 03203D } & 114022 & \text { UI } \\ \text { FSP 04703 } & 114020 & \text { UI } \\ \text { FSP 20403 } & 114018 & \text { UI } \\ \text { FSP 29003 } & 114016 & \text { UI } \\ \text { FSP 29003A } & 114017 & \text { UI } \\ \text { HSP 00803 } & 114006 & \text { UI } \\ \text { HSP 00803A } & 114007 & \text { UI } \\ \text { HSP 02903 } & 114014 & \text { UI } \\ \text { HSP 02903 } & 114014 & \text { UI } \\ \text { HSP 04303 } & 114015 & \text { UI } \\ \text { HSP 06003 } & 114012 & \text { UI } \\ \text { HSP 06003D } & 114013 & \text { J } \\ \text { HSP 06003D } & 114013 & \text { UIJ } \\ \text { HSP 09203 } & 114011 & \text { UI }\end{array}$

$\begin{array}{rlr}\text { Result } & \text { Unit } & \text { ssMDL } \\ & & \\ -1.79 \mathrm{E}-01 & \mathrm{pCi} / \mathrm{L} & 4.22 \mathrm{E}+00 \\ -8.66 \mathrm{E}-02 & \mathrm{pCi} / \mathrm{L} & 4.60 \mathrm{E}+00 \\ 1.39 \mathrm{E}+00 & \mathrm{pCi} / \mathrm{L} & 4.38 \mathrm{E}+00 \\ 3.40 \mathrm{E}+00 & \mathrm{pCi} / \mathrm{L} & 7.06 \mathrm{E}+00 \\ 9.32 \mathrm{E}-01 & \mathrm{pCi} / \mathrm{L} & 4.29 \mathrm{E}+00 \\ -1.17 \mathrm{E}-01 & \mathrm{pCi} / \mathrm{L} & 4.51 \mathrm{E}+00 \\ -3.34 \mathrm{E}-01 & \mathrm{pCi} / \mathrm{L} & 5.39 \mathrm{E}+00 \\ 2.61 \mathrm{E}-01 & \mathrm{pCi} / \mathrm{L} & 2.85 \mathrm{E}+00 \\ -1.58 \mathrm{E}-01 & \mathrm{pCi} / \mathrm{L} & 3.41 \mathrm{E}+00 \\ -1.35 \mathrm{E}+00 & \mathrm{pCi} / \mathrm{L} & 3.10 \mathrm{E}+00 \\ 3.50 \mathrm{E}-01 & \mathrm{pCi} / \mathrm{L} & 3.65 \mathrm{E}+00 \\ -3.19 \mathrm{E}-01 & \mathrm{pCi} / \mathrm{L} & 3.56 \mathrm{E}+00 \\ 1.99 \mathrm{E}+00 & \mathrm{pCi} / \mathrm{L} & 3.59 \mathrm{E}+00 \\ -8.35 \mathrm{E}-01 & \mathrm{pCi} / \mathrm{L} & 2.69 \mathrm{E}+00 \\ 9.12 \mathrm{E}-01 & \mathrm{pCi} / \mathrm{L} & 3.52 \mathrm{E}+00 \\ -8.83 \mathrm{E}-01 & \mathrm{pCi} / \mathrm{L} & 3.64 \mathrm{E}+00 \\ -1.65 \mathrm{E}+00 & \mathrm{pCi} / \mathrm{L} & 4.34 \mathrm{E}+00 \\ 1.03 \mathrm{E}+00 & \mathrm{pCi} / \mathrm{L} & 4.75 \mathrm{E}+00 \\ 2.07 \mathrm{E}+00 & \mathrm{pCi} / \mathrm{L} & 4.93 \mathrm{E}+00 \\ 1.09 \mathrm{E}+00 & \mathrm{pCi} / \mathrm{L} & 4.28 \mathrm{E}+00 \\ -2.28 \mathrm{E}-01 & \mathrm{pCi} / \mathrm{L} & 5.34 \mathrm{E}+00 \\ 1.91 \mathrm{E}+01 & \mathrm{pCi} / \mathrm{L} & 3.83 \mathrm{E}+00 \\ 1.14 \mathrm{E}+00 & \mathrm{pCi} / \mathrm{L} & 4.17 \mathrm{E}+00 \\ -5.82 \mathrm{E}-02 & \mathrm{pCi} / \mathrm{L} & 4.54 \mathrm{E}+00\end{array}$

Method

$\mathbf{A Q}$

EPIA-013

EPIA-013

EPIA-013

EPIA-013

EPIA-013

EPIA-013

EPIA-013

EPIA-013

EPIA-013

EPIA-013

EPA901.1MOD

EPIA-013

EPIA-013

EPIA-013

EPIA-013

EPIA-013

EPIA-013

EPIA-013

EPIA-013

EPIA-013

EPIA-013

EPA901.1MOD

EPA901.1MOD

EPIA-013

ANALYTE: Promethium-146

Analytical Group: Radionuclides

\begin{tabular}{|c|c|c|}
\hline Survey ID & Sample ID & $\mathbf{R Q}$ \\
\hline BG 00103 & 114003 & UI \\
\hline BG 00203 & 114004 & UI \\
\hline BG 00303 & 114005 & UI \\
\hline BG 00403 & 114010 & UI \\
\hline FMC001F03 & 114002 & UI \\
\hline FMC001H03 & 114000 & UI \\
\hline FMCOO2H03 & 114001 & UI \\
\hline FSP 01203 & 114019 & Ul \\
\hline FSP 03203 & 114021 & Ul \\
\hline FSP 03203 & 114021 & UI \\
\hline FSP 03203D & 114022 & UI \\
\hline FSP 04703 & 114020 & UI \\
\hline FSP 20403 & 114018 & UI \\
\hline FSP 29003 & 114016 & Ul \\
\hline FSP 29003A & 114017 & UI \\
\hline HSP 00803 & 114006 & UI \\
\hline HSP 00803A & 114007 & UI \\
\hline HSP 02903 & 114014 & UI \\
\hline HSP 02903 & 114014 & UI \\
\hline HSP 04303 & 114015 & UI \\
\hline HSP 06003 & 114012 & UI \\
\hline HSP $06003 \mathrm{D}$ & 114013 & UI \\
\hline HSP 06003D & 114013 & UI \\
\hline HSP 09203 & 114011 & UI \\
\hline
\end{tabular}

\begin{tabular}{|c|c|c|c|}
\hline Result & Unit & ssMDL & Method \\
\hline $1.79 \mathrm{E}+00$ & $\mathrm{pCi} / \mathrm{L}$ & $6.01 \mathrm{E}+00$ & EPIA-013 \\
\hline$-7.85 \mathrm{E}-01$ & $\mathrm{pCi} / \mathrm{L}$ & $5.71 \mathrm{E}+00$ & EPIA-013 \\
\hline $1.56 \mathrm{E}+00$ & $\mathrm{pCi} / \mathrm{L}$ & $5.17 \mathrm{E}+00$ & EPIA-013 \\
\hline $1.20 \mathrm{E}+00$ & $\mathrm{pCi} / \mathrm{L}$ & $8.83 E+00$ & EPIA-013 \\
\hline $7.83 \mathrm{E}-01$ & $\mathrm{pCi} / \mathrm{L}$ & $5.49 \mathrm{E}+00$ & EPIA-013 \\
\hline$-1.82 \mathrm{E}+00$ & $\mathrm{pCi} / \mathrm{L}$ & $5.72 \mathrm{E}+00$ & EPIA-013 \\
\hline $1.41 E+00$ & $\mathrm{pCi} / \mathrm{L}$ & $6.64 \mathrm{E}+00$ & EPIA-013 \\
\hline $2.83 \mathrm{E}+00$ & $\mathrm{pCi} / \mathrm{L}$ & $4.24 \mathrm{E}+00$ & EPIA-013 \\
\hline$-5.05 \mathrm{E}-01$ & $\mathrm{pCi} / \mathrm{L}$ & $4.57 \mathrm{E}+00$ & EPIA-013 \\
\hline $9.72 \mathrm{E}-01$ & $\mathrm{pCi} / \mathrm{L}$ & $4.51 \mathrm{E}+00$ & EPIA-013 \\
\hline$-5.50 \mathrm{E}-01$ & $\mathrm{pCi} / \mathrm{L}$ & $5.73 \mathrm{E}+00$ & EPA901.1MOD \\
\hline$-8.42 \mathrm{E}-01$ & $\mathrm{pCi} /$ & $3.99 \mathrm{E}+00$ & EPIA-013 \\
\hline $3.61 \mathrm{E}-01$ & $\mathrm{pCi} / \mathrm{L}$ & $4.06 \mathrm{E}+00$ & EPIA-013 \\
\hline$-6.16 \mathrm{E}-01$ & $\mathrm{pCi} / \mathrm{L}$ & $3.43 \mathrm{E}+00$ & EPIA-013 \\
\hline $2.41 \mathrm{E}-01$ & $\mathrm{pCi} / \mathrm{L}$ & $4.56 \mathrm{E}+00$ & EPIA-013 \\
\hline$-1.68 \mathrm{E}+00$ & $\mathrm{pCi} / \mathrm{L}$ & $4.69 \mathrm{E}+00$ & EPIA-013 \\
\hline 3.99E-02 & $\mathrm{pCi} / \mathrm{L}$ & $5.51 \mathrm{E}+00$ & EPIA-013 \\
\hline 4.30E-01 & $\mathrm{pCi} / \mathrm{L}$ & $5.63 \mathrm{E}+00$ & EPIA-013 \\
\hline$-1.73 \mathrm{E}+00$ & $\mathrm{pCi} / \mathrm{L}$ & $5.67 \mathrm{E}+00$ & EPIA-013 \\
\hline$-4.72 \mathrm{E}-01$ & $\mathrm{pCi} / \mathrm{L}$ & $4.98 E+00$ & EPIA-013 \\
\hline$-7.81 \mathrm{E}-01$ & $\mathrm{pCi} / \mathrm{L}$ & $6.19 \mathrm{E}+00$ & EPIA-013 \\
\hline$-5.00 \mathrm{E}-01$ & $\mathrm{pCi} / \mathrm{L}$ & $6.28 \mathrm{E}+00$ & EPA901.1MOD \\
\hline$-2.13 \mathrm{E}+00$ & $\mathrm{pCi} / \mathrm{L}$ & $6.50 \mathrm{E}+00$ & EPA901.1MOD \\
\hline $4.12 \mathrm{E}-01$ & $\mathrm{pCi} / \mathrm{L}$ & $5.95 \mathrm{E}+00$ & EPIA-013 \\
\hline
\end{tabular}


ANALYTE: Radium-226

Analytical Group: Radionuclides

\begin{tabular}{|c|c|}
\hline Survey ID & Sample ID RQ \\
\hline BG 00203 & 114004 \\
\hline BG 00203 & 114004 \\
\hline FSP 03203 & 114021 \\
\hline FSP 20403 & 114018 \\
\hline HSP 00803 & 114006 \\
\hline HSP 02903 & 114014 \\
\hline HSP 02903 & 114014 \\
\hline HSP 09203 & 114011 \\
\hline
\end{tabular}

$\begin{array}{rlrl}\text { Result } & \text { Unit } & \text { ssMDL } & \text { Method } \\ & & & \\ 2.76 \mathrm{E}+00 & \mathrm{pCi} / \mathrm{L} & 4.52 \mathrm{E}-01 & \mathrm{EPIA-008} \\ 3.29 \mathrm{E}+00 & \mathrm{pCi} / \mathrm{L} & 6.13 \mathrm{E}-01 & \mathrm{EPIA-008} \\ 6.67 \mathrm{E}-01 & \mathrm{pCi} / \mathrm{L} & 4.86 \mathrm{E}-01 & \mathrm{EPIA}-008 \\ 1.48 \mathrm{E}+01 & \mathrm{pCi} / \mathrm{L} & 1.77 \mathrm{E}-01 & \mathrm{EPIA}-008 \\ 6.80 \mathrm{E}-01 & \mathrm{pCi} / \mathrm{L} & 5.01 \mathrm{E}-01 & \mathrm{EPIA-008} \\ 7.91 \mathrm{E}+00 & \mathrm{pCi} / \mathrm{L} & 7.07 \mathrm{E}-01 & \mathrm{EPIA-008} \\ 7.29 \mathrm{E}+00 & \mathrm{pCi} / \mathrm{L} & 5.48 \mathrm{E}-01 & \mathrm{EPIA-008} \\ 1.26 \mathrm{E}+00 & \mathrm{pCi} / \mathrm{L} & 4.04 \mathrm{E}-01 & \mathrm{EPIA-008}\end{array}$

AQ

ANALYTE: Radium-228

Analytical Group: Radionuclides

$\begin{array}{lll}\text { Survey ID } & \text { Sample ID } & \text { RQ } \\ \text { FSP 03203 } & 114021 & \text { UI } \\ \text { FSP 03203D } & 114022 & \\ \text { FSP 03203D } & 114022 & \\ \text { FSP 20403 } & 114018 & \\ \text { HSP 02903 } & 114014 & \text { UI } \\ \text { HSP 02903 } & 114014 & \text { UI } \\ \text { HSP 04303 } & 114015 & \text { UI }\end{array}$

$\begin{array}{rlrl}\text { Result } & \text { Unit } & \text { ssMDL } & \text { Method } \\ & & & \\ 1.05 \mathrm{E}-01 & \mathrm{pCi} / \mathrm{L} & 1.02 \mathrm{E}+00 & \mathrm{EPIA-009} \\ 3.07 \mathrm{E}+01 & \mathrm{pCi} / \mathrm{L} & 5.75 \mathrm{E}+00 & \mathrm{EPA904.0MOD} \\ 2.60 \mathrm{E}+01 & \mathrm{pCi} / \mathrm{L} & 7.77 \mathrm{E}+00 & \mathrm{EPA904.0 \textrm {MOD }} \\ 2.64 \mathrm{E}+00 & \mathrm{pCi} / \mathrm{L} & 1.01 \mathrm{E}+00 & \mathrm{EPIA}-009 \\ 4.50 \mathrm{E}-02 & \mathrm{pCi} / \mathrm{L} & 7.11 \mathrm{E}-01 & \mathrm{EPIA-009} \\ -2.06 \mathrm{E}-01 & \mathrm{pCi} / \mathrm{L} & 7.83 \mathrm{E}-01 & \mathrm{EPIA-009} \\ 2.34 \mathrm{E}-01 & \mathrm{pCi} / \mathrm{L} & 6.74 \mathrm{E}-01 & \mathrm{EPIA-009}\end{array}$

$\mathbf{A Q}$

ANALYTE: Ruthenium-106

Analytical Group: Radionuclides

\begin{tabular}{|c|c|c|c|c|c|c|c|}
\hline Survey ID & Sample ID & $\mathbf{R Q}$ & $\mathbf{B}$ & Result & Unit & ssMDL & Method \\
\hline BG 00103 & 114003 & UI & & $-1.24 \mathrm{E}+01$ & $\mathrm{pCi} / \mathrm{L}$ & $3.75 \mathrm{E}+01$ & EPIA-013 \\
\hline BG 00203 & 114004 & UI & & $2.19 \mathrm{E}+00$ & $\mathrm{pCi} / \mathrm{L}$ & $4.33 \mathrm{E}+01$ & EPIA-013 \\
\hline BG 00303 & 114005 & UI & & $9.22 \mathrm{E}+00$ & $\mathrm{pCi} / \mathrm{L}$ & $4.05 \mathrm{E}+01$ & EPIA-013 \\
\hline BG 00403 & 114010 & UI & & $2.00 \mathrm{E}+01$ & $\mathrm{pCi} / \mathrm{L}$ & $6.46 \mathrm{E}+01$ & EPIA-013 \\
\hline FMC001F03 & 114002 & UI & & $1.26 \mathrm{E}+01$ & $\mathrm{pCi} / \mathrm{L}$ & $4.05 E+01$ & EPIA-013 \\
\hline FMCOO1H03 & 114000 & UI & & $-7.76 \mathrm{E}+00$ & $\mathrm{pCi} / \mathrm{L}$ & $4.04 \mathrm{E}+01$ & EPIA-013 \\
\hline $\mathrm{FMCO02H03}$ & 114001 & UI & & $-2.05 \mathrm{E}+01$ & $\mathrm{pCi} / \mathrm{L}$ & $5.05 \mathrm{E}+01$ & EPIA-013 \\
\hline FSP 01203 & 114019 & UI & & $9.89 \mathrm{E}+00$ & $\mathrm{pCi} / \mathrm{L}$ & $3.33 E+01$ & EPIA-013 \\
\hline FSP 03203 & 114021 & UI & & $9.02 \mathrm{E}+00$ & $\mathrm{pCi} / \mathrm{L}$ & $3.29 \mathrm{E}+01$ & EPIA-013 \\
\hline FSP 03203 & 114021 & UI & & $3.44 \mathrm{E}+00$ & $\mathrm{pCi} / \mathrm{L}$ & $3.02 \mathrm{E}+01$ & EPIA-013 \\
\hline FSP 03203D & 114022 & UI & & $3.15 \mathrm{E}+00$ & $\mathrm{pCi} / \mathrm{L}$ & $3.26 \mathrm{E}+01$ & EPA901.1MOD \\
\hline FSP 04703 & 114020 & UI & & $1.56 \mathrm{E}+00$ & $\mathrm{pCi} / \mathrm{L}$ & $3.35 \mathrm{E}+01$ & EPIA-013 \\
\hline FSP 20403 & 114018 & UI & & $-2.65 \mathrm{E}+00$ & $\mathrm{pCi} / \mathrm{L}$ & $3.01 \mathrm{E}+01$ & EPIA-013 \\
\hline FSP 29003 & 114016 & UI & & $-1.21 \mathrm{E}+00$ & $\mathrm{pCi} / \mathrm{L}$ & $2.51 \mathrm{E}+01$ & EPIA-013 \\
\hline FSP 29003A & 114017 & UI & & $-7.79 \mathrm{E}+00$ & $\mathrm{pCi} / \mathrm{L}$ & $3.04 \mathrm{E}+01$ & EPIA-013 \\
\hline HSP 00803 & 114006 & UI & & $-1.35 \mathrm{E}+01$ & $\mathrm{pCi} / \mathrm{L}$ & $3.50 \mathrm{E}+01$ & EPIA-013 \\
\hline HSP 00803A & 114007 & UI & & $8.75 \mathrm{E}+00$ & $\mathrm{pCi} / \mathrm{L}$ & $3.97 E+01$ & EPIA-013 \\
\hline HSP 02903 & 114014 & UI & & $-1.52 \mathrm{E}+01$ & $\mathrm{pCi} / \mathrm{L}$ & $3.66 \mathrm{E}+01$ & EPIA-013 \\
\hline HSP 02903 & 114014 & UI & & $7.08 \mathrm{E}+00$ & $\mathrm{pCi} / \mathrm{L}$ & $4.53 \mathrm{E}+01$ & EPIA-013 \\
\hline HSP 04303 & 114015 & UI & & $-5.92 \mathrm{E}+00$ & $\mathrm{pCi} / \mathrm{L}$ & $3.54 \mathrm{E}+01$ & EPIA-013 \\
\hline HSP 06003 & 114012 & UI & & $5.64 \mathrm{E}+00$ & $\mathrm{pCi} / \mathrm{L}$ & $5.02 E+01$ & EPIA-013 \\
\hline HSP 06003D & 114013 & UI & & $-2.54 \mathrm{E}+00$ & $\mathrm{pCi} / \mathrm{L}$ & $3.49 E+01$ & EPA901.1MOD \\
\hline HSP 06003D & 114013 & $\mathrm{UI}$ & & $-7.29 \mathrm{E}+00$ & $\mathrm{pCi} / \mathrm{L}$ & $3.29 E+01$ & EPA901.1MOD \\
\hline HSP 09203 & 114011 & UI & & $-3.35 \mathrm{E}+00$ & $\mathrm{pCi} / \mathrm{L}$ & $4.30 \mathrm{E}+01$ & EPIA-013 \\
\hline
\end{tabular}

AQ

Data Summary Report for the Annual Fourmile Branch and

F- and H-Area Seeplines, Appendix IX Metals and Radionuclides, 1998

(WSRC-TR-98-00260) 
ANALYTE: Selenium

Analytical Group: Metals (total recoverable)

$\begin{array}{llrrrrrl}\text { Survey ID } & \text { Sample ID } & \text { RQ } & \text { B } & \text { Result } & \text { Unit } & \text { ssMDL } & \text { Method } \\ \text { BG 00103 } & 114003 & U & 5 & \mu \mathrm{g} / \mathrm{L} & 1.4 & \text { EPA6010A } \\ \text { BG 00203 } & 114004 & \mathrm{U} & 5 & \mu \mathrm{g} / \mathrm{L} & 1.4 & \text { EPA6010A } \\ \text { BG 00303 } & 114005 & \mathrm{U} & 5 & \mu \mathrm{g} / \mathrm{L} & 1.4 & \text { EPA6010A } \\ \text { BG 00403 } & 114010 & \mathrm{U} & 5 & \mu \mathrm{g} / \mathrm{L} & 1.4 & \text { EPA6010A } \\ \text { FMC001F03 } & 114002 & \mathrm{U} & 5 & \mu \mathrm{g} / \mathrm{L} & 1.4 & \text { EPA6010A } \\ \text { FMC001H03 } & 114000 & \mathrm{U} & 5 & \mu \mathrm{g} / \mathrm{L} & 1.4 & \text { EPA6010A } \\ \text { FMC002H03 } & 114001 & \mathrm{U} & 5 & \mu \mathrm{g} / \mathrm{L} & 1.4 & \text { EPA6010A } \\ \text { FSP 01203 } & 114019 & \mathrm{U} & 5 & \mu \mathrm{g} / \mathrm{L} & 1.4 & \text { EPA6010A } \\ \text { FSP 03203 } & 114021 & \mathrm{U} & 5 & \mu \mathrm{g} / \mathrm{L} & 1.4 & \text { EPA6010A } \\ \text { FSP 03203D } & 114022 & \mathrm{U} & 66 & \mu \mathrm{g} / \mathrm{L} & 6.6 & \text { EPA6010 } \\ \text { FSP 04703 } & 114020 & \mathrm{U} & 5 & \mu \mathrm{g} / \mathrm{L} & 1.4 & \text { EPA6010A } \\ \text { FSP 20403 } & 114018 & \mathrm{U} & 10 & \mu \mathrm{g} / \mathrm{L} & 2.8 & \text { EPA6010A } \\ \text { FSP 29003 } & 114016 & \mathrm{U} & 5 & \mu \mathrm{g} / \mathrm{L} & 1.4 & \text { EPA6010A } \\ \text { FSP 29003A } & 114017 & \mathrm{U} & 5 & \mu \mathrm{g} / \mathrm{L} & 1.4 & \text { EPA6010A } \\ \text { HSP 00803 } & 114006 & \mathrm{U} & 5 & \mu \mathrm{g} / \mathrm{L} & 1.4 & \text { EPA6010A } \\ \text { HSP 00803A } & 114007 & \mathrm{U} & 5 & \mu \mathrm{g} / \mathrm{L} & 1.4 & \text { EPA6010A } \\ \text { HSP 02903 } & 114014 & \mathrm{U} & 5 & \mu \mathrm{g} / \mathrm{L} & 1.4 & \text { EPA6010A } \\ \text { HSP 04303 } & 114015 & \mathrm{U} & 5 & \mu \mathrm{g} / \mathrm{L} & 1.4 & \text { EPA6010A } \\ \text { HSP 06003 } & 114012 & \mathrm{U} & 5 & \mu \mathrm{g} / \mathrm{L} & 1.4 & \text { EPA6010A } \\ \text { HSP 06003D } & 114013 & \mathrm{U} & 66 & \mu \mathrm{g} / \mathrm{L} & 6.6 & \text { EPA6010 } \\ \text { HSP 09203 } & 114011 & \mathrm{U} & 5 & \mu \mathrm{g} / \mathrm{L} & 1.4 & \text { EPA6010A }\end{array}$

ANALYTE: Silver

Analytical Group: Metals (total recoverable)

\begin{tabular}{|c|c|c|}
\hline Survey ID & Sample ID & $\mathbf{R Q}$ \\
\hline $\mathrm{BG} 00103$ & 114003 & $U$ \\
\hline BG 00203 & 114004 & U \\
\hline BG 00303 & 114005 & $\mathrm{U}$ \\
\hline BG 00403 & 114010 & $\mathrm{U}$ \\
\hline FMC001F03 & 114002 & U \\
\hline FMC0O1HO3 & 114000 & $\mathrm{U}$ \\
\hline FMC002 $\mathrm{HO}$ & 114001 & $\mathrm{U}$ \\
\hline FSP 01203 & 114019 & $\mathrm{U}$ \\
\hline FSP 03203 & 114021 & $\mathrm{U}$ \\
\hline FSP 03203D & 114022 & $\mathrm{U}$ \\
\hline ESP 04703 & 114020 & $\mathrm{U}$ \\
\hline FSP 20403 & 114018 & U \\
\hline FSP 29003 & 114016 & $\mathrm{U}$ \\
\hline FSP 29003A & 114017 & $\mathrm{U}$ \\
\hline HSP 00803 & 114006 & $\mathrm{U}$ \\
\hline HSP 00803A & 114007 & $\mathrm{U}$ \\
\hline HSP 02903 & 114014 & $\mathrm{U}$ \\
\hline HSP 04303 & 114015 & $\mathrm{U}$ \\
\hline HSP 06003 & 114012 & $\mathrm{U}$ \\
\hline HSP $06003 \mathrm{D}$ & 114013 & $\mathrm{U}$ \\
\hline HSP 09203 & 114011 & $\mathrm{U}$ \\
\hline
\end{tabular}

$\begin{array}{rlrl}\text { Result } & \text { Unit } & \text { ssMDL } & \text { Method } \\ 5 & \mu \mathrm{g} / \mathrm{L} & 0.62 & \text { EPA6010A } \\ 5 & \mu \mathrm{g} / \mathrm{L} & 0.62 & \text { EPA6010A } \\ 5 & \mu \mathrm{g} / \mathrm{L} & 0.62 & \text { EPA6010A } \\ 3.1 & \mu \mathrm{g} / \mathrm{L} & 0.62 & \text { EPA6010A } \\ 5 & \mu \mathrm{g} / \mathrm{L} & 0.62 & \text { EPA6010A } \\ 5 & \mu \mathrm{g} / \mathrm{L} & 0.62 & \text { EPA6010A } \\ 5 & \mu \mathrm{g} / \mathrm{L} & 0.62 & \text { EPA6010A } \\ 5 & \mu \mathrm{g} / \mathrm{L} & 0.62 & \text { EPA6010A } \\ 1.38 & \mu \mathrm{g} / \mathrm{L} & 0.62 & \text { EPA6010A } \\ 5 & \mu \mathrm{g} / \mathrm{L} & 0.5 & \text { EPA6010 } \\ 1.09 & \mu \mathrm{g} / \mathrm{L} & 0.62 & \text { EPA6010A } \\ 10 & \mu \mathrm{g} / \mathrm{L} & 1.24 & \text { EPA6010A } \\ 1.41 & \mu \mathrm{g} / \mathrm{L} & 0.62 & \text { EPA6010A } \\ 1.14 & \mu \mathrm{g} / \mathrm{L} & 0.62 & \text { EPA6010A } \\ 5 & \mu \mathrm{g} / \mathrm{L} & 0.62 & \text { EPA6010A } \\ 5 & \mu \mathrm{g} / \mathrm{L} & 0.62 & \text { EPA6010A } \\ 3.25 & \mu \mathrm{g} / \mathrm{L} & 0.62 & \text { EPA6010A } \\ 3.15 & \mu \mathrm{g} / \mathrm{L} & 0.62 & \text { EPA6010A } \\ 2.96 & \mu \mathrm{g} / \mathrm{L} & 0.62 & \text { EPA6010A } \\ 5 & \mu \mathrm{g} / \mathrm{L} & 0.5 & \text { EPA6010 } \\ 2.83 & \mu \mathrm{g} / \mathrm{L} & 0.62 & \text { EPA6010A }\end{array}$


ANALYTE: Sodium

Analytical Group: Metals (total recoverable)

$\begin{array}{ll}\text { Survey ID } & \text { Sample ID RQ } \\ & \\ \text { BG 00103 } & 114003 \\ \text { BG 00203 } & 114004 \\ \text { BG 00303 } & 114005 \\ \text { BG 00403 } & 114010 \\ \text { FMC001F03 } & 114002 \\ \text { FMC001H03 } & 114000 \\ \text { FMC002H03 } & 114001 \\ \text { FSP 01203 } & 114019 \\ \text { FSP 03203 } & 114021 \\ \text { FSP 03203D } & 114022 \\ \text { FSP 04703 } & 114020 \\ \text { FSP 20403 } & 114018 \\ \text { FSP 29003 } & 114016 \\ \text { FSP 29003A } & 114017 \\ \text { HSP 00803 } & 114006 \\ \text { HSP 00803A } & 114007 \\ \text { HSP 02903 } & 114014 \\ \text { HSP 04303 } & 114015 \\ \text { HSP 06003 } & 114012 \\ \text { HSP 06003D } & 114013 \\ \text { HSP 09203 } & 114011\end{array}$

$\begin{array}{rlrl}\text { Result } & \text { Unit } & \text { ssMDL } & \text { Method } \\ & & & \\ 932 & \mu \mathrm{g} / \mathrm{L} & 29.1 & \text { EPA6010A } \\ 927 & \mu \mathrm{g} / \mathrm{L} & 29.1 & \text { EPA6010A } \\ 1470 & \mu \mathrm{g} / \mathrm{L} & 29.1 & \text { EPA6010A } \\ 1650 & \mu \mathrm{g} / \mathrm{L} & 29.1 & \text { EPA6010A } \\ 4250 & \mu \mathrm{g} / \mathrm{L} & 29.1 & \text { EPA6010A } \\ 3630 & \mu \mathrm{g} / \mathrm{L} & 29.1 & \text { EPA6010A } \\ 3940 & \mu \mathrm{g} / \mathrm{L} & 29.1 & \text { EPA6010A } \\ 1480 & \mu \mathrm{g} / \mathrm{L} & 29.1 & \text { EPA6010A } \\ 2880 & \mu \mathrm{g} / \mathrm{L} & 29.1 & \text { EPA6010A } \\ 2620 & \mu \mathrm{g} / \mathrm{L} & 28.5 & \text { EPA6010 } \\ 2720 & \mu \mathrm{g} / \mathrm{L} & 29.1 & \text { EPA6010A } \\ 17600 & \mu \mathrm{g} / \mathrm{L} & 58.2 & \text { EPA6010A } \\ 1900 & \mu \mathrm{g} / \mathrm{L} & 29.1 & \text { EPA6010A } \\ 1860 & \mu \mathrm{g} / \mathrm{L} & 29.1 & \text { EPA6010A } \\ 13200 & \mu \mathrm{g} / \mathrm{L} & 29.1 & \text { EPA6010A } \\ 13300 & \mu \mathrm{g} / \mathrm{L} & 29.1 & \text { EPA6010A } \\ 4490 & \mu \mathrm{g} / \mathrm{L} & 29.1 & \text { EPA6010A } \\ 16100 & \mu \mathrm{g} / \mathrm{L} & 29.1 & \text { EPA6010A } \\ 25400 & \mu \mathrm{g} / \mathrm{L} & 29.1 & \text { EPA6010A } \\ 17000 & \mu \mathrm{g} / \mathrm{L} & 28.5 & \text { EPA6010 } \\ 3750 & \mu \mathrm{g} / \mathrm{L} & 29.1 & \text { EPA6010A }\end{array}$

ANALYTE: Sodium-22

Analytical Group: Radionuclides

\begin{tabular}{|c|c|c|c|c|c|c|c|}
\hline Survey ID & Sample ID & $\mathbf{R Q}$ & $\mathbf{B}$ & Result & Unit & ssMDL & Method \\
\hline BG 00103 & 114003 & UI & & $-9.05 E-02$ & $\mathrm{pCi} / \mathrm{L}$ & $4.03 E+00$ & EPIA-013 \\
\hline BG 00203 & 114004 & UI & & $9.42 \mathrm{E}-01$ & $\mathrm{pCi} / \mathrm{L}$ & $5.22 \mathrm{E}+00$ & EPIA-013 \\
\hline BG 00303 & 114005 & UI & & $2.38 \mathrm{E}+00$ & $\mathrm{pCi} / \mathrm{L}$ & $5.30 \mathrm{E}+00$ & EPIA-013 \\
\hline BG 00403 & 114010 & UI & & $1.96 \mathrm{E}+00$ & $\mathrm{pCi} / \mathrm{L}$ & $6.93 \mathrm{E}+00$ & EPIA-013 \\
\hline FMC001F03 & 114002 & U11 & & $1.91 \mathrm{E}+00$ & $\mathrm{pCi} / \mathrm{L}$ & $4.91 \mathrm{E}+00$ & EPIA-013 \\
\hline FMCOO1H03 & 114000 & $\mathrm{UI}$ & & 4.53E-01 & $\mathrm{pCi} / \mathrm{L}$ & $5.60 \mathrm{E}+00$ & EPIA-013 \\
\hline EMC002H03 & 114001 & UI & & $-1.57 \mathrm{E}+00$ & $\mathrm{pCi} / \mathrm{L}$ & $5.65 \mathrm{E}+00$ & EPIA-013 \\
\hline FSP 01203 & 114019 & UI & & $-3.28 \mathrm{E}-01$ & $\mathrm{pCi} / \mathrm{L}$ & $3.47 \mathrm{E}+00$ & EPIA-013 \\
\hline FSP 03203 & 114021 & UI & & $6.74 \mathrm{E}-03$ & $\mathrm{pCi} / \mathrm{L}$ & $3.63 E+00$ & EPIA-013 \\
\hline ESP 03203 & 114021 & UI & & $1.28 \mathrm{E}+00$ & $\mathrm{pCi} / \mathrm{L}$ & $4.11 \mathrm{E}+00$ & EPIA-013 \\
\hline FSP 03203D & 114022 & UI & & $-1.19 \mathrm{E}+00$ & $\mathrm{pCi} / \mathrm{L}$ & $3.63 E+00$ & EPA901.1MOD \\
\hline FSP 04703 & 114020 & $\mathrm{UI}$ & & $-3.79 \mathrm{E}-01$ & $\mathrm{pCi} / \mathrm{L}$ & $4.04 \mathrm{E}+00$ & EPIA-013 \\
\hline FSP 20403 & 114018 & UI & & $-1.57 E+00$ & $\mathrm{pCi} / \mathrm{L}$ & $2.77 \mathrm{E}+00$ & EPIA-013 \\
\hline FSP 29003 & 114016 & UI & & $-7.35 \mathrm{E}-01$ & $\mathrm{pCi} / \mathrm{L}$ & $2.62 \mathrm{E}+00$ & EPIA-013 \\
\hline FSP 29003A & 114017 & UI & & $-1.12 \mathrm{E}-01$ & $\mathrm{pCi} / \mathrm{L}$ & $3.62 \mathrm{E}+00$ & EPIA-013 \\
\hline HSP 00803 & 114006 & UI & & $-7.17 \mathrm{E}-01$ & $\mathrm{pCi} / \mathrm{L}$ & $4.42 \mathrm{E}+00$ & EPIA-013 \\
\hline HSP 00803A & 114007 & Ui & & $5.80 \mathrm{E}-01$ & $\mathrm{pCi} / \mathrm{L}$ & $4.99 \mathrm{E}+00$ & EPIA-013 \\
\hline HSP 02903 & 114014 & $\mathrm{UI}$ & & $-8.02 \mathrm{E}-01$ & $\mathrm{pCi} / \mathrm{L}$ & $4.32 \mathrm{E}+00$ & EPIA-013 \\
\hline HSP 02903 & 114014 & UI & & $-9.55 \mathrm{E}-01$ & $\mathrm{pCi} / \mathrm{L}$ & $4.75 \mathrm{E}+00$ & EPIA-013 \\
\hline HSP 04303 & 114015 & UI & & $-4.21 \mathrm{E}-01$ & $\mathrm{pCi} / \mathrm{L}$ & $4.37 \mathrm{E}+00$ & EPIA-013 \\
\hline HSP 06003 & 114012 & UI & & $-1.92 \mathrm{E}+00$ & $\mathrm{pCi} / \mathrm{L}$ & $5.92 \mathrm{E}+00$ & EPIA-013 \\
\hline HSP $06003 \mathrm{D}$ & 114013 & UI & & 8.60E-01 & $\mathrm{pCi} / \mathrm{L}$ & $5.08 \mathrm{E}+00$ & EPA901.1MOD \\
\hline HSP $06003 \mathrm{D}$ & 114013 & UI & & $-5.40 \mathrm{E}-01$ & $\mathrm{pCi} / \mathrm{L}$ & $4.38 E+00$ & EPA901.1MOD \\
\hline HSP 09203 & 114011 & UI & & $3.69 \mathrm{E}-01$ & $\mathrm{pCi} / \mathrm{L}$ & $4.97 \mathrm{E}+00$ & EPIA-013 \\
\hline
\end{tabular}


ANALYTE: Strontium -90

Analytical Group: Radionuclides

\begin{tabular}{|c|c|}
\hline Survey ID & Sample ID RQ \\
\hline FSP 03203D & 114022 \\
\hline FSP 03203D & 114022 \\
\hline
\end{tabular}

Result Unit ssMDL Method

FSP 03203D $\quad 114022$

$\begin{array}{llll}2.04 \mathrm{E}+01 & \mathrm{pCi} / \mathrm{L} & 1.94 \mathrm{E}+00 & \text { EMLSR02MOD } \\ 1.92 \mathrm{E}+01 & \mathrm{pCi} / \mathrm{L} & 1.73 \mathrm{E}+00 & \text { EMLSR02MOD }\end{array}$

ANALYTE: Thallium

Analytical Group: Metals (total recoverable)

\begin{tabular}{|c|c|c|c|c|c|c|}
\hline Survey ID & Sample ID & $\mathbf{R Q} \quad \mathbf{B}$ & Result & Unit & ssMDL & Method \\
\hline BG 00103 & 114003 & $\mathrm{U}$ & 10 & $\mu \mathrm{g} / \mathrm{L}$ & 2.63 & EPA6010A \\
\hline BG 00203 & 114004 & $\mathrm{U}$ & 10 & $\mu \mathrm{g} / \mathrm{L}$ & 2.63 & EPA6010A \\
\hline BG 00303 & 114005 & $\mathrm{U}$ & 10 & $\mu \mathrm{g} / \mathrm{L}$ & 2.63 & EPA6010A \\
\hline BG 00403 & 114010 & $\mathrm{U}$ & 10 & $\mu g / L$ & 2.63 & EPA6010A \\
\hline FMC001F03 & 114002 & $\mathrm{U}$ & 10 & $\mu g / L$ & 2.63 & EPA6010A \\
\hline FMC001H03 & 114000 & $\mathrm{U}$ & 10 & $\mu g / L$ & 2.63 & EPA6010A \\
\hline FMC002H03 & 114001 & $\mathrm{U}$ & 10 & $\mu g / L$ & 2.63 & EPA6010A \\
\hline FSP 01203 & 114019 & $\mathrm{U}$ & 10 & $\mu g / L$ & 2.63 & EPA6010A \\
\hline FSP 03203 & 114021 & $\mathrm{U}$ & 10 & $\mu \mathrm{g} / \mathrm{L}$ & 2.63 & EPA6010A \\
\hline FSP 03203D & 114022 & $U$ & 55 & $\mu g / L$ & 5.5 & EPA6010 \\
\hline FSP 04703 & 114020 & $\mathrm{U}$ & 10 & $\mu \mathrm{g} / \mathrm{L}$ & 2.63 & EPA6010A \\
\hline FSP 20403 & 114018 & $U$ & 20 & $\mu \mathrm{g} / \mathrm{L}$ & 5.26 & EPA6010A \\
\hline FSP 29003 & 114016 & $\mathrm{U}$ & 10 & $\mu g / L$ & 2.63 & EPA6010A \\
\hline FSP $29003 A$ & 114017 & $U$ & 10 & $\mu \mathrm{g} / \mathrm{L}$ & 2.63 & EPA6010A \\
\hline HSP 00803 & 114006 & $U$ & 10 & $\mu_{\mathrm{g}} / \mathrm{L}$ & 2.63 & EPA6010A \\
\hline HSP 00803A & 114007 & $\mathrm{U}$ & 10 & $\mu \mathrm{g} / \mathrm{L}$ & 2.63 & EPA6010A \\
\hline HSP 02903 & 114014 & $\mathrm{U}$ & 10 & $\mu \mathrm{g} / \mathrm{L}$ & 2.63 & EPA6010A \\
\hline HSP 04303 & 114015 & $U$ & 10 & $\mu \mathrm{g} / \mathrm{L}$ & 2.63 & EPA6010A \\
\hline HSP 06003 & 114012 & $U$ & 10 & $\mu \mathrm{g} / \mathrm{L}$ & 2.63 & EPA6010A \\
\hline HSP 06003D & 114013 & U & 55 & $\mu \mathrm{g} / \mathrm{L}$ & 5.5 & EPA6010 \\
\hline HSP 09203 & 114011 & $U$ & 10 & $\mu \mathrm{g} / \mathrm{L}$ & 2.63 & EPA6010A \\
\hline
\end{tabular}

ANALYTE: Tin

Analytical Group: Metals (total recoverable)

$\begin{array}{llllllll}\text { Survey ID } & \text { Sample ID } & \text { RQ } & \text { B } & \text { Result } & \text { Unit } & \text { ssMDL } & \text { Method } \\ \text { BG 00103 } & 114003 & U & 10 & \mu g / L & 2.94 & \text { EPA6010A } \\ \text { BG 00203 } & 114004 & U & 10 & \mu g / L & 2.94 & \text { EPA6010A } \\ \text { BG 00303 } & 114005 & U & 10 & \mu g / L & 2.94 & \text { EPA6010A } \\ \text { BG 00403 } & 114010 & U & 10 & \mu g / L & 2.94 & \text { EPA6010A } \\ \text { FMC001F03 } & 114002 & U & 10 & \mu \mathrm{g} / \mathrm{L} & 2.94 & \text { EPA6010A } \\ \text { FMC001H03 } & 114000 & \mathrm{U} & 10 & \mu \mathrm{g} / \mathrm{L} & 2.94 & \text { EPA6010A } \\ \text { FMC002H03 } & 114001 & \mathrm{U} & 10 & \mu \mathrm{g} / \mathrm{L} & 2.94 & \text { EPA6010A } \\ \text { FSP 01203 } & 114019 & \mathrm{U} & 10 & \mu \mathrm{g} / \mathrm{L} & 2.94 & \text { EPA6010A } \\ \text { FSP 03203 } & 114021 & \mathrm{U} & 10 & \mu \mathrm{g} / \mathrm{L} & 2.94 & \text { EPA6010A } \\ \text { FSP 03203D } & 114022 & \mathrm{U} & 70 & \mu \mathrm{g} / \mathrm{L} & 7 & \text { EPA6010 } \\ \text { FSP 04703 } & 114020 & \mathrm{U} & 10 & \mu \mathrm{g} / \mathrm{L} & 2.94 & \text { EPA6010A } \\ \text { FSP 20403 } & 114018 & \mathrm{U} & 20 & \mu \mathrm{g} / \mathrm{L} & 5.88 & \text { EPA6010A } \\ \text { FSP 29003 } & 114016 & \mathrm{U} & 10 & \mu \mathrm{g} / \mathrm{L} & 2.94 & \text { EPA6010A } \\ \text { FSP 29003A } & 114017 & \mathrm{U} & 10 & \mu \mathrm{g} / \mathrm{L} & 2.94 & \text { EPA6010A } \\ \text { HSP 00803 } & 114006 & \mathrm{U} & 10 & \mu \mathrm{g} / \mathrm{L} & 2.94 & \text { EPA6010A } \\ \text { HSP 00803A } & 114007 & \mathrm{U} & 10 & \mu \mathrm{g} / \mathrm{L} & 2.94 & \text { EPA6010A } \\ \text { HSP 02903 } & 114014 & \mathrm{U} & 10 & \mu \mathrm{g} / \mathrm{L} & 2.94 & \text { EPA6010A } \\ \text { HSP 04303 } & 114015 & \mathrm{U} & 10 & \mu \mathrm{g} / \mathrm{L} & 2.94 & \text { EPA6010A }\end{array}$

Data Summary Report for the Annual Fourmile Branch and F- and H-Area Seeplines, Appendix IX Metals and Radionuclides, 1998 (WSRC-TR-98-00260) 
ANALYTE: Tin (cont.)

$\begin{array}{llrrrrrl}\text { Survey ID } & \text { Sample ID } & \text { RQ } & \text { B } & \text { Result } & \text { Unit } & \text { ssMDL } & \text { Method } \\ \text { HSP 06003 } & 114012 & \mathrm{U} & 10 & \mu \mathrm{g} / \mathrm{L} & 2.94 & \text { EPA6010A } \\ \text { HSP 06003D } & 114013 & \mathrm{U} & 70 & \mu \mathrm{g} / \mathrm{L} & 7 & \text { EPA6010 } \\ \text { HSP 09203 } & 114011 & \mathrm{U} & 10 & \mu \mathrm{g} / \mathrm{L} & 2.94 & \text { EPA6010A }\end{array}$

ANALYTE: Tin-113

Analytical Group: Radionuclides

\begin{tabular}{|c|c|c|c|c|c|c|c|}
\hline Survey ID & Sample ID & $\mathbf{R Q}$ & $\mathbf{B}$ & Result & Unit & ssMDL & Method \\
\hline BG 00103 & 114003 & UI & & $1.32 E+00$ & $\mathrm{pCi} / \mathrm{L}$ & $5.70 \mathrm{E}+00$ & EPIA-013 \\
\hline BG 00203 & 114004 . & UI & & $3.04 E+00$ & $\mathrm{pCi} / \mathrm{L}$ & $6.23 E+00$ & EPIA-013 \\
\hline BG 00303 & 114005 & UI & & $3.15 E+00$ & $\mathrm{pCi} / \mathrm{L}$ & $5.40 \mathrm{E}+00$ & EPIA-013 \\
\hline BG 00403 & 114010 & UI & & $2.49 \mathrm{E}-01$ & $\mathrm{pCi} / \mathrm{L}$ & $8.32 \mathrm{E}+00$ & EPIA-013 \\
\hline FMC001F03 & 114002 & UI & & $-3.40 \mathrm{E}+00$ & $\mathrm{pCi} / \mathrm{L}$ & $5.28 \mathrm{E}+00$ & EPIA-013 \\
\hline FMC0O1H03 & 114000 & UI & & $-3.79 E-01$ & $\mathrm{pCi} / \mathrm{L}$ & $6.35 E+00$ & EPIA-013 \\
\hline FMCOO2HO3 & 114001 & UI & & $-2.44 E+00$ & $\mathrm{pCi} / \mathrm{L}$ & $6,58 \bar{E}+00$ & EPIA-013 \\
\hline FSP 01203 & 114019 & UI & & $1.81 \mathrm{E}+00$ & $\mathrm{pCi} / \mathrm{L}$ & $4.11 E+00$ & EPIA-013 \\
\hline FSP 03203 & 114021 & UI & & $2.92 \mathrm{E}-01$ & $\mathrm{pCi} / \mathrm{L}$ & $4.52 E+00$ & EPIA-013 \\
\hline FSP 03203 & 114021 & UI & & $1.65 \mathrm{E}+00$ & $\mathrm{pCi} / \mathrm{L}$ & $4.67 E+00$ & EPIA-013 \\
\hline FSP 03203D & 114022 & UI & & $1.89 \mathrm{E}+00$ & $\mathrm{pCi} / \mathrm{L}$ & $4.51 \mathrm{E}+00$ & EPA901.1MOD \\
\hline FSP 04703 & 114020 & UI & & $-1.68 E+00$ & $\mathrm{pCi} / 2$ & $4.29 E+00$ & EPIA-013 \\
\hline FSP 20403 & 114018 & UI & & $-1.02 \mathrm{E}-01$ & $\mathrm{pCi} / \mathrm{L}$ & $4.19 E+00$ & EPIA-013 \\
\hline FSP 29003 & 114016 & UI & & $1.56 \mathrm{E}+00$ & $\mathrm{pCi} / \mathrm{L}$ & $3.52 \mathrm{E}+00$ & EPIA-013 \\
\hline FSP 29003A & 114017 & UI & & $-1.22 \mathrm{E}+00$ & $\mathrm{pCi} / \mathrm{L}$ & $4.07 \mathrm{E}+00$ & EPIA-013 \\
\hline HSP 00803 & 114006 & UI & & $2.76 \mathrm{E}+00$ & $\mathrm{pCi} / \mathrm{L}$ & $5.30 E+00$ & EPIA-013 \\
\hline HSP 00803A & 114007 & UI & & $-4.21 E+00$ & $\mathrm{pCi} / \mathrm{L}$ & $5.47 E+00$ & EPIA-013 \\
\hline HSP 02903 & 114014 & UI & & $-2.99 E+00$ & $\mathrm{pCi} / \mathrm{L}$ & $5.17 E+00$ & EPIA-013 \\
\hline HSP 02903 & 114014 & UI & & $2.06 \mathrm{E}+00$ & $\mathrm{pCi} / \mathrm{L}$ & $6.61 E+00$ & EPIA-013 \\
\hline HSP 04303 & 114015 & UI & & $-1.26 \mathrm{E}+00$ & $\mathrm{pCi} / \mathrm{L}$ & $4.77 E+00$ & EPIA-013 \\
\hline HSP 06003 & 114012 & UI & & $-7.35 \mathrm{E}-01$ & $\mathrm{pCi} / \mathrm{L}$ & $6.34 E+00$ & EPIA-013 \\
\hline HSP 06003D & 114013 & UI & & $-1.03 \mathrm{E}+00$ & $\mathrm{pCi} / \mathrm{L}$ & $4.55 E+00$ & EPA901.1MOD \\
\hline HSP 06003D & 114013 & UI & & $1.69 \mathrm{E}+00$ & $\mathrm{pCi} / \mathrm{L}$ & $4.90 \mathrm{E}+00$ & EPA901.1MOD \\
\hline HSP 09203 & 114011 & UI & & $3.95 E+00$ & $\mathrm{pCi} / \mathrm{L}$ & $6.25 E+00$ & EPIA-013 \\
\hline
\end{tabular}

ANALYTE: Tritium

Analytical Group: Radionuclides

$\begin{array}{ll}\text { Survey ID } & \text { Sample ID RQ } \\ \text { BG } 00103 & 114003 \\ \text { BG 00203 } & 114004 \\ \text { BG 00303 } & 114005 \\ \text { BG 00403 } & 114010 \\ \text { FMC001F03 } & 114002 \\ \text { FMC001H03 } & 114000 \\ \text { FMC002H03 } & 114001 \\ \text { FSP 01203 } & 114019 \\ \text { FSP 03203 } & 114021 \\ \text { FSP 03203D } & 114022 \\ \text { FSP 04703 } & 114020 \\ \text { FSP 20403 } & 114018 \\ \text { FSP 29003 } & 114016 \\ \text { FSP 29003A } & 114017 \\ \text { HSP 00803 } & 114006\end{array}$

$\begin{array}{rlrl}\text { Result } & \text { Unit } & \text { ssMDL } & \text { Method } \\ & & & \\ 4.15 \mathrm{E}+00 & \mathrm{pCi} / \mathrm{mL} & 5.65 \mathrm{E}-01 & \text { EPA906.0 } \\ 7.34 \mathrm{E}-01 & \mathrm{pCi} / \mathrm{mL} & 6.40 \mathrm{E}-01 & \text { EPA906.0 } \\ 2.26 \mathrm{E}+00 & \mathrm{pCi} / \mathrm{mL} & 5.74 \mathrm{E}-01 & \text { EPA906.0 } \\ 1.32 \mathrm{E}+00 & \mathrm{pCi} / \mathrm{mL} & 6.20 \mathrm{E}-01 & \text { EPA906.0 } \\ 2.42 \mathrm{E}+02 & \mathrm{pCi} / \mathrm{mL} & 5.72 \mathrm{E}-01 & \text { EPA906.0 } \\ 6.66 \mathrm{E}+00 & \mathrm{pCi} / \mathrm{mL} & 5.72 \mathrm{E}-01 & \text { EPA906.0 } \\ 3.35 \mathrm{E}+01 & \mathrm{pCi} / \mathrm{mL} & 5.67 \mathrm{E}-01 & \text { EPA906.0 } \\ 4.49 \mathrm{E}+01 & \mathrm{pCi} / \mathrm{mL} & 6.00 \mathrm{E}-01 & \text { EPA906.0 } \\ 8.82 \mathrm{E}+01 & \mathrm{pCi} / \mathrm{mL} & 6.12 \mathrm{E}-01 & \text { EPA906.0 } \\ 1.04 \mathrm{E}+02 & \mathrm{pCi} / \mathrm{mL} & 6.10 \mathrm{E}-01 & \text { EPA906.0MOD } \\ 2.31 \mathrm{E}+01 & \mathrm{pCi} / \mathrm{mL} & 6.08 \mathrm{E}-01 & \text { EPA906.0 } \\ 1.62 \mathrm{E}+03 & \mathrm{pCi} / \mathrm{mL} & 2.92 \mathrm{E}+00 & \text { EPA906.0 } \\ 5.48 \mathrm{E}+01 & \mathrm{pCi} / \mathrm{mL} & 6.35 \mathrm{E}-01 & \text { EPA906.0 } \\ 5.26 \mathrm{E}+01 & \mathrm{pCi} / \mathrm{mL} & 6.35 \mathrm{E}-01 & \text { EPA906.0 } \\ 8.90 \mathrm{E}+01 & \mathrm{pCi} / \mathrm{mL} & 6.06 \mathrm{E}-01 & \text { EPA906.0 }\end{array}$


ANALYTE: Tritium (cont.)

\begin{tabular}{|c|c|}
\hline Survey ID & Sample ID RQ \\
\hline HSP 00803A & 114007 \\
\hline HSP 02903 & 114014 \\
\hline HSP 04303 & 114015 \\
\hline HSP 06003 & 114012 \\
\hline HSP 06003D & 114013 \\
\hline HSP 06003D & 114013 \\
\hline HSP 09203 & 114011 \\
\hline
\end{tabular}

$\begin{array}{rlrl}\text { Result } & \text { Unit } & \text { ssMDL } & \text { Method } \\ & & & \\ 9.36 \mathrm{E}+01 & \mathrm{pCi} / \mathrm{mL} & 5.97 \mathrm{E}-01 & \text { EPA906.0 } \\ 2.66 \mathrm{E}+01 & \mathrm{pCi} / \mathrm{mL} & 5.88 \mathrm{E}-01 & \text { EPA906.0 } \\ 1.72 \mathrm{E}+03 & \mathrm{pCi} / \mathrm{mL} & 3.07 \mathrm{E}+00 & \text { EPA906.0 } \\ 2.27 \mathrm{E}+02 & \mathrm{pCi} / \mathrm{mL} & 1.05 \mathrm{E}+00 & \text { EPA906.0 } \\ 3.29 \mathrm{E}+02 & \mathrm{pCi} / \mathrm{mL} & 5.80 \mathrm{E}-01 & \text { EPA906.0MOD } \\ 3.82 \mathrm{E}+02 & \mathrm{pCi} / \mathrm{mL} & 6.80 \mathrm{E}-01 & \text { EPA906.0MOD } \\ 1.66 \mathrm{E}+02 & \mathrm{pCi} / \mathrm{mL} & 8.47 \mathrm{E}-01 & \text { EPA906.0 }\end{array}$

AQ

ANALYTE: Uranium-233/234

Analytical Group: Radionuclides

\begin{tabular}{|c|c|}
\hline Survey ID & Sample ID RQ \\
\hline BG 00203 & 114004 \\
\hline FSP 03203 & 114021 \\
\hline FSP 03203 & 114021 \\
\hline FSP 20403 & 114018 \\
\hline HSP 00803 & 114006 \\
\hline HSP 02903 & 114014 \\
\hline HSP 09203 & 114011 \\
\hline
\end{tabular}

$\begin{array}{rlrl}\text { Result } & \text { Unit } & \text { ssMDL } & \text { Method } \\ & & & \\ 1.29 \mathrm{E}+00 & \mathrm{pCi} / \mathrm{L} & 3.17 \mathrm{E}-01 & \mathrm{EPIA}-011 \\ 2.67 \mathrm{E}-01 & \mathrm{pCi} / \mathrm{L} & 8.91 \mathrm{E}-02 & \mathrm{EPIA}-011 \\ 2.38 \mathrm{E}-01 & \mathrm{pCi} / \mathrm{L} & 1.43 \mathrm{E}-01 & \mathrm{EPIA}-011 \\ 2.81 \mathrm{E}+00 & \mathrm{pCi} / \mathrm{L} & 1.83 \mathrm{E}-01 & \mathrm{EPIA}-011 \\ 2.18 \mathrm{E}-01 & \mathrm{pCi} / \mathrm{L} & 7.28 \mathrm{E}-02 & \mathrm{EPIA}-011 \\ 5.34 \mathrm{E}-01 & \mathrm{pCi} / \mathrm{L} & 2.37 \mathrm{E}-01 & \mathrm{EPIA}-011 \\ 3.47 \mathrm{E}-01 & \mathrm{pCi} / \mathrm{L} & 1.04 \mathrm{E}-01 & \mathrm{EPIA}-011\end{array}$

ANALYTE: Uranium-235

Analytical Group: Radionuclides

\begin{tabular}{|c|c|c|c|c|c|c|}
\hline Survey ID & Sample ID & $\mathbf{R Q} \quad \mathbf{B}$ & Result & Unit & ssMDL & Method \\
\hline $\mathrm{BG} 00203$ & 114004 & UI & $2.53 \mathrm{E}-01$ & $\mathrm{pCi} / \mathrm{L}$ & 2.85E-01 & EPIA-011 \\
\hline FSP 03203 & 114021 & UI & $5.25 \mathrm{E}-02$ & $\mathrm{pCi} / \mathrm{L}$ & $1.57 \mathrm{E}-01$ & EPIA-011 \\
\hline FSP 03203 & 114021 & $\mathrm{UI}$ & $1.09 \mathrm{E}-03$ & $\mathrm{pCi} / \mathrm{L}$ & $2.06 \mathrm{E}-01$ & EPIA-011 \\
\hline FSP 20403 & 114018 & UI & 8.13E-02 & $\mathrm{pCi} / \mathrm{L}$ & $1.56 \mathrm{E}-01$ & EPIA-011 \\
\hline HSP 00803 & 114006 & UI & $1.85 \mathrm{E}-02$ & $\mathrm{pCi} / \mathrm{L}$ & $1.28 \mathrm{E}=01$ & EPIA-011 \\
\hline HSP 02903 & 114014 & UI & $1.97 \mathrm{E}-01$ & $\mathrm{pCi} / \mathrm{L}$ & $2.18 \mathrm{E}-01$ & EPIA-011 \\
\hline HSP 09203 & 114011 & UI & $6.97 \mathrm{E}-02$ & $\mathrm{pCi} / \mathrm{L}$ & $1.05 \mathrm{E}-01$ & EPIA-011 \\
\hline
\end{tabular}

ANALYTE: Uranium-238

Analytical Group: Radionuclides

$\begin{array}{lllrrrrr}\text { Survey ID } & \text { Sample ID } & \text { RQ } & \text { B } & \text { Result } & \text { Unit } & \text { ssMDL } & \text { Method } \\ \text { BG 00203 } & 114004 & & & & & & \\ \text { FSP 03203 } & 114021 & & & 9.87 \mathrm{E}-01 & \mathrm{pCi} / \mathrm{L} & 4.66 \mathrm{E}-01 & \mathrm{EPIA}-011 \\ \text { FSP 03203 } & 114021 & \text { UI } & & 4.61 \mathrm{E}-01 & \mathrm{pCi} / \mathrm{L} & 1.85 \mathrm{E}-01 & \mathrm{EPIA}-011 \\ \text { FSP 20403 } & 114018 & & 1.09 \mathrm{E}-03 & \mathrm{pCi} / \mathrm{L} & 2.05 \mathrm{E}-01 & \mathrm{EPIA}-011 \\ \text { HSP 00803 } & 114006 & & & 2.64 \mathrm{E}+00 & \mathrm{pCi} / \mathrm{L} & 1.55 \mathrm{E}-01 & \mathrm{EPIA}-011 \\ \text { HSP 02903 } & 114014 & \text { UI } & & 1.70 \mathrm{E}-01 & \mathrm{pCi} / \mathrm{L} & 7.28 \mathrm{E}-02 & \mathrm{EPIA-011} \\ \text { HSP 09203 } & 114011 & & & 4.01 \mathrm{E}-02 & \mathrm{pCi} / \mathrm{L} & 2.18 \mathrm{E}-01 & \mathrm{EPIA}-011 \\ & & & 2.08 \mathrm{E}-01 & \mathrm{pCi} / \mathrm{L} & 1.04 \mathrm{E}-01 & \mathrm{EPIA}-011\end{array}$


ANALYTE: Vanadium

Analytical Group: Metals (total recoverable)

$\begin{array}{ll}\text { Survey ID } & \text { Sample ID RQ } \\ \text { BG 00103 } & 114003 \\ \text { BG 00203 } & 114004 \\ \text { BG 00303 } & 114005 \\ \text { BG 00403 } & 114010 \\ \text { FMC001F03 } & 114002 \\ \text { FMC001H03 } & 114000 \\ \text { FMC002H03 } & 114001 \\ \text { FSP 01203 } & 114019 \\ \text { FSP 03203 } & 114021 \\ \text { FSP 03203D } & 114022 \\ \text { FSP 04703 } & 114020 \\ \text { FSP 20403 } & 114018 \\ \text { FSP 29003 } & 114016 \\ \text { FSP 29003A } & 114017 \\ \text { HSP 00803 } & 114006 \\ \text { HSP 00803A } & 114007 \\ \text { HSP 02903 } & 114014 \\ \text { HSP 04303 } & 114015 \\ \text { HSP 06003 } & 114012 \\ \text { HSP 06003D } & 114013 \\ \text { HSP 09203 } & 114011 \\ \end{array}$

ANALYTE: Yttrium-88 Analytical Group: Radionuclides

\begin{tabular}{|c|c|c|}
\hline Survey ID & Sample ID & $\mathbf{R Q}$ \\
\hline BG 00103 & 114003 & UI \\
\hline BG 00203 & 114004 & UI \\
\hline BG 00303 & 114005 & UI \\
\hline BG 00403 & 114010 & Ul \\
\hline FMC001F03 & 114002 & UI \\
\hline FMC001H03 & 114000 & UI \\
\hline $\mathrm{FMIC002H03}$ & 114001 & UI \\
\hline FSP 01203 & 114019 & UI \\
\hline ESP 03203 & 114021 & UI \\
\hline FSP 03203 & 114021 & UI \\
\hline FSP 03203D & 114022 & UI \\
\hline FSP 04703 & 114020 & UI \\
\hline FSP 20403 & 114018 & UI \\
\hline FSP 29003 & 114016 & UI \\
\hline FSP 29003A & 114017 & UI \\
\hline HSP 00803 & 114006 & UI \\
\hline HSP $00803 \mathrm{~A}$ & 114007 & UI \\
\hline HSP 02903 & 114014 & UI \\
\hline HSP 02903 & 114014 & UI \\
\hline HSP 04303 & 114015 & UI \\
\hline HSP 06003 & 114012 & UI \\
\hline HSP 06003D & 114013 & UI \\
\hline HSP 06003D & 114013 & UI \\
\hline HSP 09203 & 114011 & UI \\
\hline
\end{tabular}

$\begin{array}{rlrl}\text { Result } & \text { Unit } & \text { ssMDL } & \text { Method } \\ & & & \\ 5 & \mu \mathrm{g} / \mathrm{L} & 0.427 & \text { EPA6010A } \\ 5 & \mu \mathrm{g} / \mathrm{L} & 0.427 & \text { EPA6010A } \\ 1.57 & \mu \mathrm{g} / \mathrm{L} & 0.427 & \text { EPA6010A } \\ 5 & \mu \mathrm{g} / \mathrm{L} & 0.427 & \text { EPA6010A } \\ 5 & \mu \mathrm{g} / \mathrm{L} & 0.427 & \text { EPA6010A } \\ 5 & \mu \mathrm{g} / \mathrm{L} & 0.427 & \text { EPA6010A } \\ 1.27 & \mu \mathrm{g} / \mathrm{L} & 0.427 & \text { EPA6010A } \\ 5 & \mu \mathrm{g} / \mathrm{L} & 0.427 & \text { EPA6010A } \\ 6.9 & \mu \mathrm{g} / \mathrm{L} & 0.69 & \text { EPA6010A } \\ 1.55 & \mu \mathrm{g} / \mathrm{L} & 0.427 & \text { EPA6010A } \\ 10 & \mu \mathrm{g} / \mathrm{L} & 0.854 & \text { EPA6010A } \\ 0.977 & \mu \mathrm{g} / \mathrm{L} & 0.427 & \text { EPA6010A } \\ 0.721 & \mu \mathrm{g} / \mathrm{L} & 0.427 & \text { EPA6010A } \\ 4.59 & \mu \mathrm{g} / \mathrm{L} & 0.427 & \text { EPA6010A } \\ 4.22 & \mu \mathrm{g} / \mathrm{L} & 0.427 & \text { EPA6010A } \\ 9.07 & \mu \mathrm{g} / \mathrm{L} & 0.427 & \text { EPA6010A } \\ 1.46 & \mu \mathrm{g} / \mathrm{L} & 0.427 & \text { EPA6010A } \\ 18.4 & \mu \mathrm{g} / \mathrm{L} & 0.427 & \text { EPA6010A } \\ 10.8 & \mu \mathrm{g} / \mathrm{L} & 0.69 & \text { EPA6010 } \\ 4.29 & \mu \mathrm{g} / \mathrm{L} & 0.427 & \text { EPA6010A }\end{array}$

$\mathbf{A Q}$

E

$\mathrm{E}$

$\mathrm{E}$

E

$\mathrm{E}$

$\mathrm{E}$

$\mathbf{E}$

$\mathbf{E}$

E

$\begin{array}{rlrl}\text { Result } & \text { Unit } & \text { ssMDL } & \text { Method } \\ & & & \\ -8.84 \mathrm{E}-01 & \mathrm{pCi} / \mathrm{L} & 4.85 \mathrm{E}+00 & \text { EPIA-013 } \\ 4.76 \mathrm{E}-01 & \mathrm{pCi} / \mathrm{L} & 6.54 \mathrm{E}+00 & \text { EPIA-013 } \\ -2.29 \mathrm{E}-01 & \mathrm{pCi} / \mathrm{L} & 5.25 \mathrm{E}+00 & \mathrm{EPIA}-013 \\ 8.35 \mathrm{E}-01 & \mathrm{pCi} / \mathrm{L} & 8.03 \mathrm{E}+00 & \text { EPIA-013 } \\ -2.57 \mathrm{E}+00 & \mathrm{pCi} / \mathrm{L} & 4.79 \mathrm{E}+00 & \text { EPIA-013 } \\ 7.94 \mathrm{E}-01 & \mathrm{pCi} / \mathrm{L} & 5.76 \mathrm{E}+00 & \text { EPIA-013 } \\ 1.40 \mathrm{E}+00 & \mathrm{pCi} / \mathrm{L} & 7.36 \mathrm{E}+00 & \text { EPIA-013 } \\ -1.39 \mathrm{E}+00 & \mathrm{pCi} / \mathrm{L} & 3.87 \mathrm{E}+00 & \text { EPIA-013 } \\ 9.57 \mathrm{E}-01 & \mathrm{pCi} / \mathrm{L} & 4.72 \mathrm{E}+00 & \text { EPIA-013 } \\ 7.71 \mathrm{E}-01 & \mathrm{pCi} / \mathrm{L} & 4.87 \mathrm{E}+00 & \text { EPIA-013 } \\ -2.60 \mathrm{E}-01 & \mathrm{pCi} / \mathrm{L} & 3.56 \mathrm{E}+00 & \text { EPA901.1MOD } \\ 4.73 \mathrm{E}-01 & \mathrm{pCi} / \mathrm{L} & 3.84 \mathrm{E}+00 & \text { EPIA-013 } \\ 1.83 \mathrm{E}-02 & \mathrm{pCi} / \mathrm{L} & 4.53 \mathrm{E}+00 & \text { EPIA-013 } \\ 7.67 \mathrm{E}-01 & \mathrm{pCi} / \mathrm{L} & 3.95 \mathrm{E}+00 & \text { EPIA-013 } \\ 7.38 \mathrm{E}-01 & \mathrm{pCi} / \mathrm{L} & 4.85 \mathrm{E}+00 & \text { EPIA-013 } \\ 2.48 \mathrm{E}-01 & \mathrm{pCi} / \mathrm{L} & 5.91 \mathrm{E}+00 & \text { EPIA-013 } \\ 1.99 \mathrm{E}+00 & \mathrm{pCi} / \mathrm{L} & 5.86 \mathrm{E}+00 & \text { EPIA-013 } \\ -1.71 \mathrm{E}+00 & \mathrm{pCi} / \mathrm{L} & 4.74 \mathrm{E}+00 & \text { EPIA-013 } \\ 3.17 \mathrm{E}-01 & \mathrm{pCi} / \mathrm{L} & 6.60 \mathrm{E}+00 & \text { EPIA-013 } \\ -1.77 \mathrm{E}+00 & \mathrm{pCi} / \mathrm{L} & 5.16 \mathrm{E}+00 & \text { EPIA-013 } \\ 4.73 \mathrm{E}-01 & \mathrm{pCi} / \mathrm{L} & 7.29 \mathrm{E}+00 & \text { EPIA-013 } \\ -1.35 \mathrm{E}+00 & \mathrm{pCi} / \mathrm{L} & 4.75 \mathrm{E}+00 & \text { EPA901.1MOD } \\ 0.00 \mathrm{E}+00 & \mathrm{pCi} / \mathrm{L} & 4.72 \mathrm{E}+00 & \text { EPA901.1MOD } \\ 2.07 \mathrm{E}+00 & \mathrm{pCi} / \mathrm{L} & 6.54 \mathrm{E}+00 & \text { EPIA-013 } \\ & & & \end{array}$


ANALYTE: Zine

Analytical Group: Metals (total recoverable)

$\begin{array}{llrrrrrl}\text { Survey ID } & \text { Sample ID } & \text { RQ } & \text { B } & \text { Result } & \text { Unit } & \text { ssMDL } & \text { Method } \\ & & & & & & \\ \text { BG 00103 } & 114003 & \mathrm{U} & 3.68 & \mu \mathrm{g} / \mathrm{L} & 0.966 & \text { EPA6010A } \\ \text { BG 00203 } & 114004 & \mathrm{U} & 4.03 & \mu \mathrm{g} / \mathrm{L} & 0.966 & \text { EPA6010A } \\ \text { BG 00303 } & 114005 & \mathrm{U} & 4.9 & \mu \mathrm{g} / \mathrm{L} & 0.966 & \text { EPA6010A } \\ \text { BG 00403 } & 114010 & & 5.88 & \mu \mathrm{g} / \mathrm{L} & 0.966 & \text { EPA6010A } \\ \text { FMC001F03 } & 114002 & & 11.9 & \mu \mathrm{g} / \mathrm{L} & 0.966 & \text { EPA6010A } \\ \text { FMC001H03 } & 114000 & & 8.53 & \mu \mathrm{g} / \mathrm{L} & 0.966 & \text { EPA6010A } \\ \text { FMC002H03 } & 114001 & & 8.73 & \mu \mathrm{g} / \mathrm{L} & 0.966 & \text { EPA6010A } \\ \text { FSP 01203 } & 114019 & & 35.7 & \mu \mathrm{g} / \mathrm{L} & 0.966 & \text { EPA6010A } \\ \text { FSP 03203 } & 114021 & & 32.3 & \mu \mathrm{g} / \mathrm{L} & 0.966 & \text { EPA6010A } \\ \text { FSP 03203D } & 114022 & \mathrm{~J} & 35.8 & \mu \mathrm{g} / \mathrm{L} & 5.3 & \text { EPA6010 } \\ \text { FSP 04703 } & 114020 & & 18.2 & \mu \mathrm{g} / \mathrm{L} & 0.966 & \text { EPA6010A } \\ \text { FSP 20403 } & 114018 & & 25.1 & \mu \mathrm{g} / \mathrm{L} & 1.93 & \text { EPA6010A } \\ \text { FSP 29003 } & 114016 & & 12.1 & \mu \mathrm{g} / \mathrm{L} & 0.966 & \text { EPA6010A } \\ \text { FSP 29003A } & 114017 & & 18.1 & \mu \mathrm{g} / \mathrm{L} & 0.966 & \text { EPA6010A } \\ \text { HSP 00803 } & 114006 & \mathrm{U} & 3.53 & \mu \mathrm{g} / \mathrm{L} & 0.966 & \text { EPA6010A } \\ \text { HSP 00803A } & 114007 & \mathrm{U} & 2.01 & \mu \mathrm{g} / \mathrm{L} & 0.966 & \text { EPA6010A } \\ \text { HSP 02903 } & 114014 & & 27.8 & \mu \mathrm{g} / \mathrm{L} & 0.966 & \text { EPA6010A } \\ \text { HSP 04303 } & 114015 & \mathrm{U} & 1.45 & \mu \mathrm{g} / \mathrm{L} & 0.966 & \text { EPA6010A } \\ \text { HSP 06003 } & 114012 & & 15.9 & \mu \mathrm{g} / \mathrm{L} & 0.966 & \text { EPA6010A } \\ \text { HSP 06003D } & 114013 & \mathrm{~J} & 8.9 & \mu \mathrm{g} / \mathrm{L} & 5.3 & \text { EPA6010 } \\ \text { HSP 09203 } & 114011 & \mathrm{U} & 4.65 & \mu \mathrm{g} / \mathrm{L} & 0.966 & \text { EPA6010A }\end{array}$

$\mathbf{A Q}$

V
V
V
V

E

V
V
V
V
V
E
V

ANALYTE: Zinc-65

Analytical Group: Radionuclides

$\begin{array}{lll}\text { Survey ID } & \text { Sample ID } & \text { RQ } \\ \text { BG 00103 } & 114003 & \text { UI } \\ \text { BG 00203 } & 114004 & \text { UI } \\ \text { BG 00303 } & 114005 & \text { UI } \\ \text { BG 00403 } & 114010 & \text { UI } \\ \text { FMC001F03 } & 114002 & \text { UI } \\ \text { FMC001H03 } & 114000 & \text { UI } \\ \text { FMC002H03 } & 114001 & \text { UI } \\ \text { FSP 01203 } & 114019 & \text { UI } \\ \text { FSP 03203 } & 114021 & \text { UI } \\ \text { FSP 03203 } & 114021 & \text { UI } \\ \text { FSP 03203D } & 114022 & \text { UI } \\ \text { FSP 04703 } & 114020 & \text { UI } \\ \text { FSP 20403 } & 114018 & \text { UI } \\ \text { FSP 29003 } & 114016 & \text { UI } \\ \text { FSP 29003A } & 114017 & \text { UI } \\ \text { HSP 00803 } & 114006 & \text { UI } \\ \text { HSP 00803A } & 114007 & \text { UI } \\ \text { HSP 02903 } & 114014 & \text { UI } \\ \text { HSP 02903 } & 114014 & \text { UI } \\ \text { HSP 04303 } & 114015 & \text { UI } \\ \text { HSP 06003 } & 114012 & \text { UI } \\ \text { HSP 06003D } & 114013 & \text { UI } \\ \text { HSP 06003D } & 114013 & \text { UI } \\ \text { HSP 09203 } & 114011 & \text { UI } \\ & & \end{array}$

Result
$-1.48 E+00$
$1.05 E+00$
$2.60 E+00$
$2.43 E+00$
$-2.08 E+00$
$3.80 E+00$
$3.03 E-01$
$-1.14 E+00$
$-3.40 E+00$
$3.36 E+00$
$-4.50 E-01$
$-2.68 E+00$
$-4.73 E+00$
$-2.98 E+00$
$1.08 E+00$
$-1.49 E+00$
$-1.14 E+00$
$-2.10 E+00$
$-3.92 E+00$
$-1.97 E+00$
$3.22 E-01$
$-3.22 E+00$
$-9.00 E-02$
$-1.11 E+00$

Uni

ssMD

$\mathrm{pCi} / \mathrm{L} \quad$ 1.01E+01

$\mathrm{pCi} / \mathrm{L} \quad 9.64 \mathrm{E}+00$

$\mathrm{pCi} / \mathrm{L} \quad 8.77 \mathrm{E}+00$

$\mathrm{pCi} / \mathrm{L} \quad 1.36 \mathrm{E}+01$

$\mathrm{pCi} / \mathrm{L} \quad 8.98 \mathrm{E}+00$

$\mathrm{pCi} / \mathrm{L} \quad 1.31 \mathrm{E}+01$

$\mathrm{pCi} / \mathrm{L} \quad 6.93 \mathrm{E}+00$

$\mathrm{pCi} / \mathrm{L} \quad 6.55 \mathrm{E}+00$

$\mathrm{pCi} / \mathrm{L} \quad 8.02 \mathrm{E}+00$

pCi/L $7.15 \mathrm{E}+00$

$\mathrm{pCi} / \mathrm{L} \quad 7.51 \mathrm{E}+00$

$\mathrm{pCi} / \mathrm{L} \quad 6.39 \mathrm{E}+00$

$\mathrm{pCi} / \mathrm{L} \quad 5.67 \mathrm{E}+00$

$\mathrm{pCi} / \mathrm{L} \quad 7.14 \mathrm{E}+00$

pCi/L $7.85 \mathrm{E}+00$

$\mathrm{pCi} / \mathrm{L} \quad 9.94 \mathrm{E}+00$

$\mathrm{pCi} / \mathrm{L} \quad 1.10 \mathrm{E}+01$

$\mathrm{pCi} / \mathrm{L} \quad 1.11 \mathrm{E}+01$

$\mathrm{pCi} / \mathrm{L} \quad 8.81 \mathrm{E}+00$

$\mathrm{pCi} / \mathrm{L} \quad 1.15 \mathrm{E}+01$

$\mathrm{pCi} / \mathrm{L} \quad 7.45 \mathrm{E}+00$

$\mathrm{pCi} / \mathrm{L} \quad 1.03 \mathrm{E}+01$
$\mathrm{pCi} / \mathrm{L} \quad 1.11 \mathrm{E}+01$

$\mathrm{pCi} / \mathrm{L} \quad 8.18 \mathrm{E}+00$

Method
EPIA-013
EPIA-013
EPIA-013
EPIA-013
EPIA-013
EPIA-013
EPIA-013
EPIA-013
EPIA-013
EPIA-013
EPA901.1MOD
EPIA-013
EPIA-013
EPIA-013
EPIA-013
EPIA-013
EPIA-013
EPIA-013
EPIA-013
EPIA-013
EPIA-013
EPA901.1MOD
EPA901.1MOD
EPIA-013


ANALYTE: Zirconium-95

Analytical Group: Radionuclides

$\begin{array}{lll}\text { Survey ID } & \text { Sample ID RQ } \\ \text { BG 00103 } & 114003 & \text { UI } \\ \text { BG 00203 } & 114004 & \text { UI } \\ \text { BG 00303 } & 114005 & \text { UI } \\ \text { BG 00403 } & 114010 & \text { UI } \\ \text { FMC001F03 } & 114002 & \text { UI } \\ \text { FMC001H03 } & 114000 & \text { UI } \\ \text { FMC002H03 } & 114001 & \text { UI } \\ \text { FSP 01203 } & 114019 & \text { UI } \\ \text { FSP 03203 } & 114021 & \text { UI } \\ \text { FSP 03203 } & 114021 & \text { UI } \\ \text { FSP 03203D } & 114022 & \text { UI } \\ \text { FSP 04703 } & 114020 & \text { UI } \\ \text { FSP 20403 } & 114018 & \text { UI } \\ \text { FSP 29003 } & 114016 & \text { UI } \\ \text { FSP 29003A } & 114017 & \text { UI } \\ \text { HSP 00803 } & 114006 & \text { UI } \\ \text { HSP 00803A } & 114007 & \text { UI } \\ \text { HSP 02903 } & 114014 & \text { UI } \\ \text { HSP 02903 } & 114014 & \text { UI } \\ \text { HSP 04303 } & 114015 & \text { UI } \\ \text { HSP 06003 } & 114012 & \text { UI } \\ \text { HSP 06003D } & 114013 & \text { UI } \\ \text { HSP 06003D } & 114013 & \text { UI } \\ \text { HSP 09203 } & 114011 & \text { UI }\end{array}$

I

UI

UI
B

\section{UI}

UI

$\begin{array}{rlll}\text { Result } & \text { Unit } & \text { ssMDL } & \text { Method } \\ & & & \\ 2.87 \mathrm{E}+00 & \mathrm{pCi} / \mathrm{L} & 9.73 \mathrm{E}+00 & \text { EPIA-013 } \\ -2.02 \mathrm{E}+00 & \mathrm{pCi} / \mathrm{L} & 8.45 \mathrm{E}+00 & \text { EPIA-013 } \\ 1.01 \mathrm{E}+00 & \mathrm{pCi} / \mathrm{L} & 8.63 \mathrm{E}+00 & \text { EPIA-013 } \\ -4.78 \mathrm{E}+00 & \mathrm{pCi} / \mathrm{L} & 1.16 \mathrm{E}+01 & \text { EPIA-013 } \\ -3.84 \mathrm{E}-01 & \mathrm{pCi} / \mathrm{L} & 8.38 \mathrm{E}+00 & \text { EPIA-013 } \\ -1.34 \mathrm{E}+00 & \mathrm{pCi} / \mathrm{L} & 9.23 \mathrm{E}+00 & \text { EPIA-013 } \\ -4.67 \mathrm{E}+00 & \mathrm{pCi} / / & 1.00 \mathrm{E}+01 & \text { EPIA-013 } \\ -1.39 \mathrm{E}+00 & \mathrm{pCi} / & 5.87 \mathrm{E}+00 & \text { EPIA-013 } \\ 2.26 \mathrm{E}+00 & \mathrm{pCi} / \mathrm{L} & 7.28 \mathrm{E}+00 & \text { EPIA-013 } \\ -4.65 \mathrm{E}-01 & \mathrm{pCi} / \mathrm{L} & 6.35 \mathrm{E}+00 & \text { EPIA-013 } \\ 2.13 \mathrm{E}+00 & \mathrm{pCi} / \mathrm{L} & 7.33 \mathrm{E}+00 & \text { EPA901.1MOD } \\ 9.74 \mathrm{E}-01 & \mathrm{pCi} / \mathrm{L} & 6.76 \mathrm{E}+00 & \text { EPIA-013 } \\ -2.23 \mathrm{E}+00 & \mathrm{pCi} / / & 5.80 \mathrm{E}+00 & \text { EPIA-013 } \\ 1.33 \mathrm{E}+00 & \mathrm{pCi} / \mathrm{L} & 6.20 \mathrm{E}+00 & \text { EPIA-013 } \\ 1.85 \mathrm{E}+00 & \mathrm{pCi} / \mathrm{L} & 6.93 \mathrm{E}+00 & \text { EPIA-013 } \\ -8.69 \mathrm{E}-01 & \mathrm{pCi} / \mathrm{L} & 7.82 \mathrm{E}+00 & \text { EPIA-013 } \\ -7.48 \mathrm{E}-01 & \mathrm{pCi} / \mathrm{L} & 8.49 \mathrm{E}+00 & \text { EPIA-013 } \\ 3.43 \mathrm{E}+00 & \mathrm{pCi} / / & 8.73 \mathrm{E}+00 & \text { EPIA-013 } \\ -3.87 \mathrm{E}+00 & \mathrm{pCi} / / & 9.79 \mathrm{E}+00 & \text { EPIA-013 } \\ -9.78 \mathrm{E}-01 & \mathrm{pCi} / / & 7.88 \mathrm{E}+00 & \text { EPIA-013 } \\ -2.41 \mathrm{E}+00 & \mathrm{pCi} / \mathrm{L} & 9.59 \mathrm{E}+00 & \text { EPIA-013 } \\ 2.53 \mathrm{E}+00 & \mathrm{pCi} / \mathrm{L} & 1.01 \mathrm{E}+01 & \text { EPA901.1MOD } \\ 1.93 \mathrm{E}+00 & \mathrm{pCi} / \mathrm{L} & 8.72 \mathrm{E}+00 & \text { EPA901.1MOD } \\ 8.68 \mathrm{E}+00 & \mathrm{pCi} / \mathrm{L} & 9.83 \mathrm{E}+00 & \text { EPIA-013 }\end{array}$

AQ 
Table D.12 Blank Results Sorted by Analyte

ANALYTE: Actinium-228

Analytical Group: Radionuclides

$\begin{array}{llllllll}\text { Survey ID } & \text { Sample ID } & \text { RQ } & \text { B } & \text { Result } & \text { Unit } & \text { ssMDL } & \text { Method } \\ \text { FSP FB02C } & 114009 & \text { UI } & & 1.18 \mathrm{E}+01 & \text { pCi/L } & 1.94 \mathrm{E}+01 & \text { EPIA-013 } \\ \text { HSP FB02C } & 114008 & \text { UI } & & 2.67 \mathrm{E}+00 & \mathrm{pCi} / \mathrm{L} & 1.88 \mathrm{E}+01 & \text { EPIA-013 }\end{array}$

ANALYTE: Aluminum

Analytical Group: Metals (total recoverable)

$\begin{array}{llcc}\text { Survey ID } & \text { Sample ID } & \text { RQ } & \text { B } \\ \text { FSP FB02C } & 114009 & \text { J } & \\ \text { HSP FB02C } & 114008 & \text { J } & \end{array}$

$\begin{array}{rrrl}\text { Result } & \text { Unit } & \text { ssMDL } & \text { Method } \\ & & & \\ 42.4 & \mu \mathrm{g} / \mathrm{L} & 37.6 & \text { EPA6010A } \\ 43.2 & \mu \mathrm{g} / \mathrm{L} & 37.6 & \text { EPA6010A }\end{array}$

$\mathbf{A Q}$

HSP FB02C 114008

ANALYTE: Antimony

Analytical Group: Metals (total recoverable)

$\begin{array}{llrrrrrrr}\text { Survey ID } & \text { Sample ID } & \text { RQ } & \text { B } & \text { Result } & \text { Unit } & \text { ssMDL } & \text { Method } & \text { AQ } \\ \text { FSP FB02C } & 114009 & \text { J } & & 1.89 & \mu g / \mathrm{L} & 1.64 & \text { EPA6010A } \\ \text { HSP FB02C } & 114008 & \text { J } & & 2.32 & \mu \mathrm{g} / \mathrm{L} & 1.64 & \text { EPA6010A }\end{array}$

ANALYTE: Antimony-124

Analytical Group: Radionuclides

$\begin{array}{llllllll}\text { Survey ID } & \text { Sample ID } & \text { RQ } & \text { B } & \text { Result } & \text { Unit } & \text { ssMDL } & \text { Method } \\ \text { FSP FB02C } & 114009 & \text { UI } & & 1.31 \mathrm{E}+00 & \mathrm{pCi} / \mathrm{L} & 5.42 \mathrm{E}+00 & \mathrm{EPIA}-013 \\ \text { HSP FB02C } & 114008 & \text { UI } & & 1.58 \mathrm{E}+00 & \mathrm{pCi} / \mathrm{L} & 5.44 \mathrm{E}+00 & \mathrm{EPIA}-013\end{array}$

ANALYTE: Antimony-125

Analytical Group: Radionuclides

$\begin{array}{llllllll}\text { Survey ID } & \text { Sample ID } & \text { RQ } & \text { B } & \text { Result } & \text { Unit } & \text { ssMDL } & \text { Method } \\ \text { FSP FB02C } & 114009 & \text { UI } & & -5.35 E+00 & \mathrm{pCi} / \mathrm{L} & 1.02 \mathrm{E}+01 & \text { EPIA-013 } \\ \text { HSP FB02C } & 114008 & \text { UI } & & -3.24 \mathrm{E}+00 & \mathrm{pCi} / \mathrm{L} & 1.06 \mathrm{E}+01 & \mathrm{EPIA}-013\end{array}$

ANALYTE: Arsenic

Analytical Group: Metals (total recoverable)

$\begin{array}{llrrrrrr}\text { Survey ID } & \text { Sample ID } & \text { RQ } & \text { B } & \text { Result } & \text { Unit } & \text { ssMDL } & \text { Method } \\ \text { FSP FB02C } & 114009 & \text { U } & 5 & \mu g / L & 2.98 & \text { EPA6010A } \\ \text { HSP FB02C } & 114008 & \text { J } & 3.81 & \mu \mathrm{g} / \mathrm{L} & 2.98 & \text { EPA6010A }\end{array}$


ANALYTE: Barium

Analytical Group: Metals (lotal recoverable)

$\begin{array}{llrrrrrr}\text { Survey ID } & \text { Sample ID } & \text { RQ } & \text { B } & \text { Result } & \text { Unit } & \text { ssMDL } & \text { Method } \\ \text { FSP FB02C } & 114009 & \text { U } & 5 & \mu \mathrm{g} / \mathrm{L} & 0.332 & \text { EPA6010A } \\ \text { HSP FB02C } & 114008 & \text { J } & 0.597 & \mu \mathrm{g} / \mathrm{L} & 0.332 & \text { EPA6010A }\end{array}$

HSP FBO2C $114008 \quad J$

ANALYTE: Barium-133

Analytical Group: Radionuclides

$\begin{array}{llllllll}\text { Survey ID } & \text { Sample ID } & \text { RQ } & \text { B } & \text { Result } & \text { Unit } & \text { saMDL } & \text { Method } \\ \text { FSP FB02C } & 114009 & \text { UI } & & -3.10 \mathrm{E}+00 & \mathrm{pCi} / \mathrm{L} & 5.20 \mathrm{E}+00 & \mathrm{EPIA}-013 \\ \text { HSP FB02C } & 114008 & \text { UI } & & -1.50 \mathrm{E}+00 & \mathrm{pCi} / \mathrm{L} & 5.34 \mathrm{E}+00 & \mathrm{EPIA}-013\end{array}$

ANALYTE: Beryllium

Analytical Group: Metals (total recoverable)

Survey ID Sample ID RQ

Result Unit ssMDL Method

$\mathbf{A Q}$

FSP FB02C $114009 \quad U$

HSP FB02C 114008

$5 \mu \mathrm{g} / \mathrm{L} \quad 0.223 \quad$ EPA6010A

$5 \mu \mathrm{g} / \mathrm{L} \quad 0.223 \quad \mathrm{EPA6010A}$

ANALYTE: Cadmium

Analytical Group: Metals (total recoverable)

$\begin{array}{llclrrrr}\text { Survey ID } & \text { Sample ID } & \text { RQ } & \text { B } & \text { Result } & \text { Unit } & \text { ssMDL } & \text { Method } \\ \text { FSP FB02C } & 114009 & U & & 5 & \mu g / L & 0.208 & \text { EPA6010A } \\ \text { HSP FB02C } & 114008 & U & 5 & \mu g / L & 0.208 & \text { EPA6010A }\end{array}$

ANALYTE: Calcium

Analytical Group: Metals (total recoverable)

Survey ID Sample ID RQ B

Result Unit ssMDL Method

$\mathbf{A Q}$

FSP FB02C $114009 \quad U$

$16.6 \mu \mathrm{g} / \mathrm{L} \quad 15.4 \quad$ EPA6010A

$\begin{array}{lll}17.6 \mu \mathrm{g} / \mathrm{L} & 15.4 \quad \text { EPA6010A }\end{array}$

$\mathbf{A Q}$

HSP FB02C 114008 U

ANALYTE: Cerium-144

Analytical Group: Radionuclides

$\begin{array}{llllrlrl}\text { Survey ID } & \text { Sample ID } & \text { RQ } & \text { B } & \text { Result } & \text { Unit } & \text { ssMDL } & \text { Method } \\ \text { FSP FB02C } & 114009 & \text { UI } & & -7.78 E+00 & \text { pCi/L } & 2.68 E+01 & \text { EPIA-013 } \\ \text { HSP FB02C } & 114008 & \text { UI } & & 2.23 E+01 & \text { pCi/L } & 2.86 E+01 & \text { EPIA-013 }\end{array}$

Data Summary Report for the Annual Fourmile Branch and

F- and H-Area Seeplines, Appendix IX Metals and Radionuclides, 1998

(WSRC-TR-98-00260) 
ANALYTE: Cesium-134

Analytical Group: Radionuclides

$\begin{array}{llllllll}\text { Survey ID } & \text { Sample ID } & \text { RQ } & \text { B } & \text { Result } & \text { Unit } & \text { ssMDL } & \text { Method } \\ \text { FSP FB02C } & 114009 & \text { UI } & & -9.63 \mathrm{E}-02 & \mathrm{pCi} / \mathrm{L} & 4.17 \mathrm{E}+00 & \text { EPIA-013 } \\ \text { HSP FB02C } & 114008 & \text { UI } & & -6.04 \mathrm{E}-01 & \mathrm{pCi} / \mathrm{L} & 4.13 \mathrm{E}+00 & \text { EPIA-013 }\end{array}$

ANALYTE: Cesium-137

Analytical Group: Radionuclides

$\begin{array}{llllllll}\text { Survey ID } & \text { Sample ID } & \text { RQ } & \text { B } & \text { Result } & \text { Unit } & \text { ssMDL } & \text { Method } \\ & & & & & & & \\ \text { FSP FB02C } & 114009 & \text { UI } & & -1.03 \mathrm{E}+00 & \mathrm{pCi} / \mathrm{L} & 3.92 \mathrm{E}+00 & \text { EPIA-013 } \\ \text { HSP FB02C } & 114008 & \text { UI } & & -8.34 \mathrm{E}-01 & \mathrm{pCi} / \mathrm{L} & 4.03 \mathrm{E}+00 & \text { EPIA-013 }\end{array}$

ANALYTE: Chromium

Analytical Group: Metals (Lotal recoverable)

$\begin{array}{llrrrrrr}\text { Survey ID } & \text { Sample ID } & \text { RQ } & \text { B } & \text { Result } & \text { Unit } & \text { ssMDL } & \text { Method } \\ \text { FSP FB02C } & 114009 & U & 5 & \mu \mathrm{g} / \mathrm{L} & 0.729 & \text { EPA6010A } \\ \text { HSP FB02C } & 114008 & \mathrm{U} & 5 & \mu \mathrm{g} / \mathrm{L} & 0.729 & \text { EPA6010A }\end{array}$

ANALYTE: Cobalt

Analytical Group: Metals (total recoverable)

$\begin{array}{llllrlrl}\text { Survey ID } & \text { Sample ID } & \text { RQ } & \text { B } & \text { Result } & \text { Unit } & \text { ssMDL } & \text { Method } \\ \text { FSP FB02C } & 114009 & \text { U } & & 5 & \boldsymbol{\mu g} / \mathrm{L} & 0.671 & \text { EPA6010A } \\ \text { HSP FB02C } & 114008 & \text { U } & 5 & \boldsymbol{\mu g} / \mathrm{L} & 0.671 & \text { EPA6010A }\end{array}$

ANALYTE: Cobalt-57

Analytical Group: Radionuclides

$\begin{array}{llrlrlrl}\text { Survey ID } & \text { Sample ID } & \text { RQ } & \text { B } & \text { Result } & \text { Unit } & \text { ssMDL } & \text { Method } \\ & & & & -1.11 \mathrm{E}+00 & \mathrm{pCi} / \mathrm{L} & 3.33 \mathrm{E}+00 & \text { EPIA-013 } \\ \text { FSP FB02C } & 114009 & \text { UI } & 7.11 \mathrm{E}-03 & \mathrm{pCi} / \mathrm{L} & 3.59 \mathrm{E}+00 & \text { EPIA-013 }\end{array}$

ANALYTE: Cobalt-58

Analytical Group: Radionuclides

$\begin{array}{llllrlrl}\text { Survey ID } & \text { Sample ID } & \text { RQ } & \text { B } & \text { Result } & \text { Unit } & \text { ssMDL } & \text { Method } \\ & & & & & & & \\ \text { FSP FB02C } & 114009 & \text { UI } & & 3.08 \mathrm{E}+00 & \text { pCi/ } & 5.50 \mathrm{E}+00 & \text { EPIA-013 } \\ \text { HSP FB02C } & 114008 & \text { UI } & & 2.70 \mathrm{E}-01 & \text { pCi/L } & 4.94 \mathrm{E}+00 & \text { EPIA-013 }\end{array}$

Data Summary Report for the Annual Fourmile Branch and

F- and H-Area Seeplines, Appendix IX Metals and Radionuclides, 1998

(WSRC-TR-98-00260) 
ANALYTE: Cobalt-60

Analytical Group: Radionuclides

$\begin{array}{llllrlrl}\text { Survey ID } & \text { Sample ID } & \text { RQ } & \text { B } & \text { Result } & \text { Unit } & \text { ssMDL } & \text { Method } \\ & & & & & & & \\ \text { FSP FB02C } & 114009 & \text { UI } & & 1.01 \mathrm{E}+00 & \text { pCi/L } & 5.04 \mathrm{E}+00 & \text { EPIA-013 } \\ \text { HSP FB02C } & 114008 & \text { UI } & & -2.80 \mathrm{E}-01 & \text { pCi/L } & 4.87 \mathrm{E}+00 & \text { EPIA-013 }\end{array}$

ANALYTE: Copper

Analytical Group: Metals (total recoverable)

$\begin{array}{llrrrrrl}\text { Survey ID } & \text { Sample ID } & \text { RQ } & \text { B } & \text { Result } & \text { Unit } & \text { ssMDL } & \text { Method } \\ \text { FSP FB02C } & 114009 & \mathrm{U} & 5 & \mu \mathrm{g} / & 1.32 & \text { EPA6010A } \\ \text { HSP FB02C } & 114008 & \mathrm{U} & 5 & \mu \mathrm{g} / \mathrm{L} & 1.32 & \text { EPA6010A }\end{array}$

ANALYTE: Cyanide

Analytical Group: Specified Analyses

$\begin{array}{llll}\text { Survey ID } & \text { Sample ID } & \text { RQ } & \text { B } \\ & & & \\ \text { FSP FB02C } & 114009 & \text { UJ } & \text { L } \\ \text { FSP FB02C } & 114009 & \text { UJ } & \text { L } \\ \text { HSP FB02C } & 114008 & \text { UJ } & \text { L }\end{array}$

$\begin{array}{rlrl}\text { Result } & \text { Unit } & \text { ssMDL } & \text { Method } \\ & & & \\ 10 & \mu \mathrm{g} / \mathrm{L} & 3.34 & \text { EPA335.3 } \\ 10 & \mu \mathrm{g} / \mathrm{L} & 3.34 & \text { EPA335.3 } \\ 10 & \mu \mathrm{g} / \mathrm{L} & 3.34 & \text { EPA335.3 }\end{array}$

ANALYTE: Europium-152

Analytical Group: Radionuclides

$\begin{array}{llllrlrl}\text { Survey ID } & \text { Sample ID } & \text { RQ } & \text { B } & \text { Result } & \text { Unit } & \text { ssMDL } & \text { Method } \\ & & & & & & & \\ \text { FSP FB02C } & 114009 & \text { UI } & & -2.69 \mathrm{E}+00 & \mathrm{pCi} / \mathrm{L} & 1.20 \mathrm{E}+01 & \text { EPIA-013 } \\ \text { HSP FB02C } & 114008 & \text { UI } & & 1.91 \mathrm{E}+00 & \mathrm{pCi} / \mathrm{L} & 1.22 \mathrm{E}+01 & \text { EPIA-013 }\end{array}$

ANALYTE: Europium-154

Analytical Group: Radionuclides

$\begin{array}{llrlrlrl}\text { Survey ID } & \text { Sample ID } & \text { RQ } & \text { B } & \text { Result } & \text { Unit } & \text { ssMDL } & \text { Method } \\ & & & & & & & \\ \text { FSP FB02C } & 114009 & \text { UI } & & 4.21 \mathrm{E}+00 & \mathrm{pCi} / \mathrm{L} & 1.34 \mathrm{E}+01 & \text { EPIA-013 } \\ \text { HSP FB02C } & 114008 & \text { UI } & & -7.51 \mathrm{E}-01 & \mathrm{pCi} / \mathrm{L} & 1.17 \mathrm{E}+01 & \text { EPIA-013 }\end{array}$

ANALYTE: Europium-155

Analytical Group: Radionuclides

$\begin{array}{llllllll}\text { Survey ID } & \text { Sample ID } & \text { RQ } & \text { B } & \text { Result } & \text { Unit } & \text { ssMDL } & \text { Method } \\ & & & & & & & \\ \text { FSP FB02C } & 114009 & \text { UI } & & 5.79 \mathrm{E}+00 & \mathrm{pCi} / \mathrm{L} & 1.44 \mathrm{E}+01 & \text { EPIA-013 } \\ \text { HSP FB02C } & 114008 & \text { UI } & & -7.24 \mathrm{E}-01 & \mathrm{pCi} / \mathrm{L} & 1.42 \mathrm{E}+01 & \text { EPIA-013 }\end{array}$


ANALYTE: Gross alpha

Analytical Group: Radionuclides

$\begin{array}{llllrlrl}\text { Survey ID } & \text { Sample ID } & \text { RQ } & \text { B } & \text { Result } & \text { Unit } & \text { ssMDL } & \text { Method } \\ \text { FSP FB02C } & 114009 & \text { UI } & & 2.00 \mathrm{E}-01 & \mathrm{pCi} / \mathrm{L} & 4.22 \mathrm{E}-01 & \text { EPIA-001 } \\ \text { HSP FB02C } & 114008 & \text { UI } & -7.22 \mathrm{E}-02 & \mathrm{pCi} / \mathrm{L} & 5.37 \mathrm{E}-01 & \text { EPIA-001 }\end{array}$

ANALYTE: Iron

Analytical Group: Metals (total recoverable)

Survey ID Sample ID RQ B

$\begin{array}{rrrl}\text { Result } & \text { Unit } & \text { ssMDL } & \text { Method } \\ 50 & \mu \mathrm{g} / \mathrm{L} & 8.63 & \text { EPA6010A } \\ 50 & \mu \mathrm{g} / \mathrm{L} & 8.63 & \text { EPA6010A }\end{array}$

FSP FB02C $114009 \quad U$

HSP FB02C $114008 \quad U$

ANALYTE: Lead

Analytical Group: Metals (total recoverable)

\begin{tabular}{|c|c|c|c|c|c|c|c|}
\hline Survey ID & Sample ID & $\mathbf{R Q}$ & B & Result & Unit & ssMDL & Method \\
\hline FSP FB02C & 114009 & $\mathrm{U}$ & & 5 & $\mu \mathrm{g} / \mathrm{L}$ & 0.678 & EPA6010A \\
\hline HSP FB02C & 114008 & $\mathrm{U}$ & & 1.25 & $\mu \mathrm{g} / \mathrm{L}$ & 0.678 & EPA6010A \\
\hline \multicolumn{8}{|c|}{$\begin{array}{l}\text { ANALYTE: Lead-212 } \\
\text { Analytical Group: Radionuclides }\end{array}$} \\
\hline Survey ID & Sample ID & $\mathbf{R Q}$ & $\mathbf{B}$ & Result & Unit & ssMDL & Method \\
\hline FSP FB02C & 114009 & UI & & $1.82 \mathrm{E}+00$ & $\mathrm{pCi} / \mathrm{L}$ & $8.77 \mathrm{E}+00$ & EPIA-013 \\
\hline HSP FB02C & 114008 & UI & & $5.83 \mathrm{E}+00$ & $\mathrm{pCi} / \mathrm{L}$ & $8.97 E+00$ & EPIA-013 \\
\hline
\end{tabular}

ANALYTE: Magnesium

Analytical Group: Melals (tolal recoverable)

$\begin{array}{llrrrrrr}\text { Survey ID } & \text { Sample ID } & \text { RQ } & \text { B } & \text { Result } & \text { Unit } & \text { ssMDL } & \text { Method } \\ \text { FSP FB02C } & 114009 & U & 10 & \mu g / L & 3.33 & \text { EPA6010A } \\ \text { HSP FB02C } & 114008 & U & 10 & \mu g / L & 3.33 & \text { EPA6010A }\end{array}$

ANALYTE: Manganese

Analytical Group: Metals (total recoverable)

$\begin{array}{llrrrrrr}\text { Survey ID } & \text { Sample ID } & \text { RQ } & \text { B } & \text { Result } & \text { Unit } & \text { ssMDL } & \text { Method } \\ \text { FSP FB02C } & 114009 & U & 10 & \mu g / L & 0.903 & \text { EPA6010A } \\ \text { HSP FB02C } & 114008 & \text { U } & 10 & \mu \mathrm{g} / \mathrm{L} & 0.903 & \text { EPA6010A }\end{array}$


ANALYTE: Manganese-54

Analytical Group: Radionuclides

$\begin{array}{llllrlrl}\text { Survey ID } & \text { Sample ID } & \text { RQ } & \text { B } & \text { Result } & \text { Unit } & \text { ssMDL } & \text { Method } \\ & & & & & & & \\ \text { FSP FB02C } & 114009 & \text { UI } & & 2.26 \mathrm{E}+00 & \mathrm{pCi} / \mathrm{L} & 4.87 \mathrm{E}+00 & \text { EPIA-013 } \\ \text { HSP FB02C } & 114008 & \text { UI } & -1.69 \mathrm{E}+00 & \mathrm{pCi} / \mathrm{L} & 4.29 \mathrm{E}+00 & \text { EPIA-013 }\end{array}$

ANALYTE: Mercury

Analytical Group: Metals (total recoverable)

$\begin{array}{llrrrrrr}\text { Survey ID } & \text { Sample ID } & \text { RQ } & \text { B } & \text { Result } & \text { Unit } & \text { ssMDL } & \text { Method } \\ \text { FSP FB02C } & 114009 & \mathrm{U} & & 0.2 & \mu \mathrm{g} / \mathrm{L} & 0.104 & \text { EPA7470 } \\ \text { HSP FB02C } & 114008 & \mathrm{U} & 0.2 & \mu \mathrm{g} / \mathrm{L} & \mathbf{0 . 1 0 4} & \text { EPA7470 }\end{array}$

ANALYTE: Neptunium-239

Analytical Group: Radionuclides

$\begin{array}{llllrlrl}\text { Survey ID } & \text { Sample ID } & \text { RQ } & \text { B } & \text { Result } & \text { Unit } & \text { ssMDL } & \text { Method } \\ & & & & & & & \\ \text { FSP FB02C } & 114009 & \text { UI } & & -6.16 \mathrm{E}+00 & \mathrm{pCi} / \mathrm{L} & 2.38 \mathrm{E}+01 & \text { EPIA-013 } \\ \text { HSP FB02C } & 114008 & \text { UI } & 3.33 \mathrm{E}+00 & \mathrm{pCi} / \mathrm{L} & 2.69 \mathrm{E}+01 & \text { EPIA-013 }\end{array}$

ANALYTE: Nickel

Analytical Group: Metals (total recoverable)

$\begin{array}{llrrrrrl}\text { Survey ID } & \text { Sample ID } & \text { RQ } & \text { B } & \text { Result } & \text { Unit } & \text { ssMDL } & \text { Method } \\ \text { FSP FB02C } & 114009 & U & 5 & \mu g / L & 2.27 & \text { EPA6010A } \\ \text { HSP FB02C } & 114008 & U & 5 & \mu \mathrm{g} / \mathrm{L} & 2.27 & \text { EPA6010A }\end{array}$

ANALYTE: Nonvolatile beta

Analytical Group: Radionuclides

$\begin{array}{llllrlrl}\text { Survey ID } & \text { Sample ID } & \text { RQ } & \text { B } & \text { Result } & \text { Unit } & \text { ssMDL } & \text { Method } \\ \text { FSP FB02C } & 114009 & \text { UI } & & -2.19 \mathrm{E}-01 & \mathrm{pCi} / \mathrm{L} & 1.09 \mathrm{E}+00 & \text { EPIA-001 } \\ \text { HSP FB02C } & 114008 & \text { UI } & & 5.81 \mathrm{E}-01 & \mathrm{pCi} / \mathrm{L} & 1.10 \mathrm{E}+00 & \text { EPIA-001 }\end{array}$

ANALYTE: Potassium

Analytical Group: Metals (lotal recoverable)

$\begin{array}{llrrrrrl}\text { Survey ID } & \text { Sample ID } & \text { RQ } & \text { B } & \text { Result } & \text { Unit } & \text { ssMDL } & \text { Method } \\ \text { FSP FB02C } & 114009 & \mathrm{U} & & & & & \\ \text { HSP FB02C } & 114008 & \mathrm{U} & & 17.2 & \mu \mathrm{g} / \mathrm{L} & 5.87 & \text { EPA6010A } \\ & & & 12.8 & \mu \mathrm{g} / \mathrm{L} & 5.87 & \text { EPA6010A }\end{array}$

$\mathbf{A Q}$ 
ANALYTE: Potassium-40

Analytical Group: Radionuclides

$\begin{array}{llllllll}\text { Survey ID } & \text { Sample ID } & \text { RQ } & \text { B } & \text { Result } & \text { Unit } & \text { ssMDL } & \text { Method } \\ \text { FSP FB02C } & 114009 & \text { UI } & & 1.18 \mathrm{E}+01 & \mathrm{pCi} / \mathrm{L} & 4.09 \mathrm{E}+01 & \text { EPIA-013 } \\ \text { HSP FB02C } & 114008 & \text { UI } & & 4.94 \mathrm{E}+01 & \mathrm{pCi} / \mathrm{L} & 6.52 \mathrm{E}+01 & \text { EPIA-013 }\end{array}$

ANALYTE: Promethium-144

Analytical Group: Radionuclides

$\begin{array}{llllrlrl}\text { Survey ID } & \text { Sample ID } & \text { RQ } & \text { B } & \text { Result } & \text { Unit } & \text { ssMDL } & \text { Method } \\ \text { FSP FB02C } & 114009 & \text { UI } & & 2.45 \mathrm{E}+00 & \mathrm{pCi} / \mathrm{L} & 4.69 \mathrm{E}+00 & \text { EPIA-013 } \\ \text { HSP FB02C } & 114008 & \text { UI } & & 1.48 \mathrm{E}+00 & \mathrm{pC} / \mathrm{L} & 4.46 \mathrm{E}+00 & \text { EPIA-013 }\end{array}$

ANALYTE: Promethium-146

Analytical Group: Radionuclides

$\begin{array}{llllrlrl}\text { Survey ID } & \text { Sample ID } & \text { RQ } & \text { B } & \text { Result } & \text { Unit } & \text { ssMDL } & \text { Method } \\ & & & & & & & \\ \text { FSP FB02C } & 114009 & \text { UI } & -1.03 E+00 & \text { pCi } / \mathrm{L} & 5.05 E+00 & \text { EPIA-013 } \\ \text { HSP FB02C } & 114008 & \text { UI } & -4.82 \mathrm{E}-01 & \mathrm{pCi} / \mathrm{L} & 5.15 \mathrm{E}+00 & \text { EPIA-013 }\end{array}$

ANALYTE: Ruthenium-106

Analytical Group: Radionuclides

$\begin{array}{llllllll}\text { Survey ID } & \text { Sample ID } & \text { RQ } & \text { B } & \text { Result } & \text { Unit } & \text { ssMDL } & \text { Method } \\ \text { FSP FB02C } & 114009 & \text { UI } & & 3.22 \mathrm{E}+01 & \mathrm{pCi} / \mathrm{L} & 3.63 \mathrm{E}+01 & \text { EPIA-013 } \\ \text { HSP FB02C } & 114008 & \text { UI } & & 2.53 \mathrm{E}+00 & \mathrm{pCi} / \mathrm{L} & 3.77 \mathrm{E}+01 & \text { EPIA-013 }\end{array}$

ANALYTE: Selenium

Analytical Group: Metals (total recoverable)

$\begin{array}{llrrrrrl}\text { Survey ID } & \text { Sample ID RQ } & \text { B } & \text { Result } & \text { Unit } & \text { ssMDL } & \text { Method } \\ & & & & & & \\ \text { FSP FB02C } & 114009 & \mathrm{U} & 5 & \mu \mathrm{g} / \mathrm{L} & 1.4 & \text { EPA6010A } \\ \text { HSP FB02C } & 114008 & \mathrm{U} & 5 & \mu \mathrm{g} / \mathrm{L} & 1.4 & \text { EPA6010A }\end{array}$

ANALYTE: Silver

Analytical Group: Metals (lotal recoverable)

$\begin{array}{llrrrrrl}\text { Survey ID } & \text { Sample ID } & \text { RQ } & \text { B } & \text { Result } & \text { Unit } & \text { ssMDL } & \text { Method } \\ & & & & 2.58 & \mu \mathrm{g} / & 0.62 & \text { EPA6010A } \\ \text { FSP FB02C } & 114009 & U & & 2.55 & \mu \mathrm{g} / \mathrm{L} & 0.62 & \text { EPA6010A }\end{array}$

$\mathbf{A Q}$

AQ

$\mathrm{V}$

Data Summary Report for the Annual Fourmile Branch and

F- and H-Area Seeplines, Appendix IX Metals and Radionuclides, 1998

(WSRC-TR-98-00260) 
ANALYTE: Sodium

Analytical Group: Metals (total recoverable)

\begin{tabular}{|c|c|c|c|c|c|c|c|}
\hline Survey ID & Sample ID & $\mathbf{R Q}$ & B & Result & Unit & ssMDL & Method \\
\hline FSP FB02C & 114009 & $\mathrm{U}$ & & 41.4 & $\mu \mathrm{g} / \mathrm{L}$ & 29.1 & EPA6010A \\
\hline HSP FB02C & 114008 & $U$ & & 37.8 & $\mu \mathrm{g} / \mathrm{L}$ & 29.1 & EPA6010A \\
\hline \multicolumn{8}{|c|}{$\begin{array}{l}\text { ANALYTE: Sodium- } 22 \\
\text { Analytical Group: Radionuclides }\end{array}$} \\
\hline Survey ID & Sample ID & $\mathbf{R Q}$ & B & Result & Unit & ssMDL & Method \\
\hline $\begin{array}{l}\text { FSP FB02C } \\
\text { HSP FB02C }\end{array}$ & $\begin{array}{l}114009 \\
114008\end{array}$ & $\begin{array}{l}\text { UI } \\
\text { UI }\end{array}$ & & $\begin{array}{l}1.51 \mathrm{E}+00 \\
-7.84 \mathrm{E}-01\end{array}$ & $\begin{array}{l}\mathrm{p} \mathrm{Ci} / \mathrm{L} \\
\mathrm{p} \mathrm{Ci} / \mathrm{L}\end{array}$ & $\begin{array}{l}4.22 \mathrm{E}+00 \\
4.21 \mathrm{E}+00\end{array}$ & $\begin{array}{l}\text { EPIA-013 } \\
\text { EPIA-013 }\end{array}$ \\
\hline
\end{tabular}

ANALYTE: Thallium

Analytical Group: Metals (total recoverable)

$\begin{array}{llrrrrrl}\text { Survey ID } & \text { Sample ID } & \text { RQ } & \text { B } & \text { Result } & \text { Unit } & \text { ssMDL } & \text { Method } \\ & & & & & & \\ \text { FSP FB02C } & 114009 & U & 10 & \mu \mathrm{g} / \mathrm{L} & 2.63 & \text { EPA6010A } \\ \text { HSP FB02C } & 114008 & \mathrm{U} & 10 & \mu \mathrm{g} / \mathrm{L} & 2.63 & \text { EPA6010A }\end{array}$

ANALYTE: Tin

Analytical Group: Metals (total recoverable)

$\begin{array}{llrrrrrl}\text { Survey ID } & \text { Sample ID } & \text { RQ } & \text { B } & \text { Result } & \text { Unit } & \text { ssMDL } & \text { Method } \\ & & & & & & \\ \text { FSP FB02C } & 114009 & U & 10 & \mu g / L & 2.94 & \text { EPA6010A } \\ \text { HSP FB02C } & 114008 & U & 10 & \mu g / L & 2.94 & \text { EPA6010A }\end{array}$

ANALYTE: Tin-113

Analytical Group: Radionuclides

\begin{tabular}{|c|c|c|c|c|c|c|c|}
\hline Survey ID & Sample ID & $\mathbf{R Q}$ & $\mathbf{B}$ & Result & Unit & ssMDL & Method \\
\hline $\begin{array}{l}\text { FSP FB02C } \\
\text { HSP FB0? }\end{array}$ & $\begin{array}{l}114009 \\
114008\end{array}$ & UI & & $\begin{array}{r}4.48 \mathrm{E}+00 \\
846 \mathrm{~F}-01\end{array}$ & $\mathrm{pCi} / \mathrm{L}$ & $\begin{array}{l}6.05 \mathrm{E}+00 \\
5.49 \mathrm{~F}+00\end{array}$ & EPIA-013 \\
\hline HSP FB02C & 114008 & UI & & 8.46E-01 & $\mathrm{pCi} / \mathrm{L}$ & $5.49 \mathrm{E}+00$ & EPIA-013 \\
\hline
\end{tabular}

ANALYTE: Vanadium

Analytical Group: Metals (total recoverable)

$\begin{array}{llrrrrrl}\text { Survey ID } & \text { Sample ID } & \text { RQ } & \text { B } & \text { Result } & \text { Unit } & \text { ssMDL } & \text { Method } \\ \text { FSP FB02C } & 114009 & U & 5 & \mu \mathrm{g} / \mathrm{L} & 0.427 & \text { EPA6010A } \\ \text { HSP FB02C } & 114008 & U & 5 & \mu \mathrm{g} / \mathrm{L} & 0.427 & \text { EPA6010A }\end{array}$


ANALYTE: Yttrium-88

Analytical Group: Radionuclides

$\begin{array}{lccrrrrr}\text { Survey ID } & \text { Sample ID } & \text { RQ } & \text { B } & \text { Result } & \text { Unit } & \text { ssMDL } & \text { Method } \\ & & & & -2.96 \mathrm{E}+00 & \text { pCi/L } & 5.29 \mathrm{E}+00 & \text { EPIA-013 } \\ \text { FSP FB02C } & 114009 & \text { UI } & & 4.61 \mathrm{E}-01 & \text { pCi/L } & 6.02 \mathrm{E}+00 & \text { EPIA-013 }\end{array}$

ANALYTE: Zinc

Analytical Group: Metals (total recoverable)

$\begin{array}{llcrrrrrr}\text { Survey ID } & \text { Sample ID } & \text { RQ } & \text { B } & \text { Result } & \text { Unit } & \text { ssMDL } & \text { Method } & \text { AQ } \\ \text { FSP FB02C } & 114009 & U & & 2.49 & \mu g / L & 0.966 & \text { EPA6010A } & \text { V } \\ \text { HSP FB02C } & 114008 & \text { U } & 2.43 & \mu g / L & 0.966 & \text { EPA6010A }\end{array}$

ANALYTE: Zinc-65

Analytical Group: Radionuclides

$\begin{array}{llllllll}\text { Survey ID } & \text { Sample ID } & \text { RQ } & \text { B } & \text { Result } & \text { Unit } & \text { ssMDL } & \text { Method } \\ \text { FSP FB02C } & 114009 & \text { UI } & & 8.16 \mathrm{E}-01 & \text { pCi/L } & 9.10 \mathrm{E}+00 & \text { EPIA-013 } \\ \text { HSP FB02C } & 114008 & \text { UI } & & -3.41 \mathrm{E}-01 & \text { pCi/L } & 9.31 \mathrm{E}+00 & \text { EPIA-013 }\end{array}$

ANALYTE: Zirconium-95

Analytical Group: Radionuclides

\begin{tabular}{|c|c|c|c|c|c|c|c|}
\hline Survey ID & Sample ID & $\mathbf{R Q}$ & $\mathbf{B}$ & Result & Unit & ssMDL & Method \\
\hline FSP FB02C & 114009 & UI & & $5.53 \mathrm{E}+00$ & $\mathrm{pCi} / \mathrm{L}$ & $9.94 \mathrm{E}+00$ & \\
\hline $\mathrm{HSP}$ FB02C & 114008 & UI & & $1.72 E+00$ & $\mathrm{pCi} / \Lambda$ & $8.60 \mathrm{E}+00$ & EPIA-013 \\
\hline
\end{tabular}




\section{Appendix E: Data Management/Administrative Files}

This section discusses the generation, processing, and storage of paper and computer records produced during the completion of this project. The processing of the materials follows methodology prescribed by EGG EPD/EMS.

EGG establishes administrative files for each project that are maintained as permanent SRS records. The following materials are placed in the administrative files:

- Bound sample-collection logbooks

- Original copies of the chain-of-custody forms

- Case narratives from the laboratories

- Data-validation logbooks

- Data-entry cover sheets for data files created by EGG

- Copies of all correspondence between data validation personnel and the laboratories

EGG generates computer data files from paper records using double-entry methods to ensure a low transcription error rate. Computer data files for analytical data also are received from the laboratories. Changes to the data are recorded in the data-validation logbook, approved by the project technical manager, and confirmed through a computer program by comparing the modified and original data files. EGG stores the final computer data files, original source files, and computer listings of all changes made to the original files in the administrative files.

Access to the administrative files remains with the manager of EGG. Paper materials eventually will be transferred to permanent box storage; however, EGG plans to make the final data files available to SRS computer users indefinitely. Please contact the manager of EGG to obtain access to this data. 
This page was left blank intentionally. 


\section{Appendix F: Glossary}

Acceptance limits: The range of acceptable analytical results established by a laboratory for spike recovery, duplicate precision, and contamination levels.

Accuracy: The closeness of agreement between an observed value and an accepted reference value.

Activity: The rate of decay of a radioactive source at a given time.

Advisory range: The limits of acceptable analytical results established by the provider of certified quality control standards.

Aliquot: A measured portion of a sample taken for analysis.

Analysis: The separation and determination of the component parts or a specific property or element contained within a sample. The determination of the concentration or activity of an analyte contained within a sample.

Analysis date/time: The date and military time (24-hour clock) of the start of analysis on a prepared sample.

Analysis qualifier (AQ): See Qualifier.

Analyte: The specific compound, element, isotope, or radionuclide of interest that an analyst seeks to determine.

Analytical batch: A group of samples of the same matrix analyzed together using the same method and containing the required number of method blanks, matrix spike samples, laboratory control samples, and duplicate samples.

Analytical narrative: A portion of the data package that includes laboratory, contract, and sample identification. The analytical narrative also contains descriptive documentation of any problems encountered in processing the samples, along with corrective action taken and problems resolved.

Analytical sample: Any solution or medium introduced into an instrument on which an analysis is performed, excluding instrument calibration standards, calibration verification standards, and calibration blanks.

Appendix IX analytes: The list of analytes specified in Appendix IX of the Code of Federal Regulations, Tille 40, Part 264 that is required by the Resource Conservation and Recovery Act.

Aquifer: A geologic formation, group of formations, or part of a formation capable of yielding groundwater to wells or springs.

Associated sample: Any sample that is related to another sample or quality control sample. Some examples are the parent sample of a matrix spike, a sample in a preparation batch, a split sample, a duplicate sample, and a sample related to a blank.

Data Summary Report for the Annual Fourmile Branch and 
Batch: A group of samples prepared at the same time, in the same location, using the same method.

Bias qualifier (BQ): See Qualifier.

Blank: An artificial sample designed to monitor the introduction of artifacts into the measurement process. For aqueous samples, deionized water is used as the blank matrix. A universal matrix does not exist for solid samples; therefore, no matrix blank is routinely used. There are several types of blanks that monitor a variety of processes. They are

- A Field Blank for Soils consists of DI water or dry quartz sand placed in a stainless steel bowl and exposed to the atmosphere while the associated sample is being taken. The field blank is shipped to the laboratory with the samples. The field blank measures contamination introduced during sample collection.

- A Field Blank for Groundwater is a sample container filled with DI water and capped in the WSRC well building. It is taken to the field during sampling, but is not opened. It is shipped to the laboratory with the samples to be analyzed.

- A Rinsate or Equipment Blank is deionized water poured over or through sample collection devices that tests for cleanliness of sampling equipment.

- A Trip Blank is shipped to the laboratory in the same cooler with the sample containers for volatile organic analytes. It provides a test for contamination from sample preservation and transport as well as sample storage, preparation, and analysis.

- A Method Blank is prepared in the laboratory and analyzed exactly as the samples it accompanies. It is a test for contamination in laboratory sample preparation and analyses.

These blanks are handled by the laboratory as actual samples; however, they are not to be used for matrix spike or duplicate samples.

\section{Blank spike (BS): See Laboratory Control Sample.}

Calibration: The establishment of an instrument response curve or mathematical correlation based on the measured response of known concentrations of an analyte or group of analytes.

Calibration blank: A volume of deionized water in the same matrix as the calibration standards, an empty planchet, or the instrument geometry that is analyzed to establish the instrument accuracy at the low end of the calibration curve.

Calibration verification: The periodic analysis of one or more standards independent of the calibration standards to verify the accuracy and stability of the initial instrument calibration.

Cation exchange capacity: The sum of exchangeable cations a soil can absorb expressed in milli-equivalents per 100 grams of soil. The cation exchange capacity is determined by sampling to the depth of solid waste placement and analyzing by the summation method for distinctly acid soils or the sodium acetate method for neutral, calcareous, or saline soils. 
Certified value: The known concentration of an analyte in a reference sample as affirmed by the preparer.

Chain-of-custody (COC) form: A document designed to trace the custody of a sample(s) from the point of origin to final disposition, with the intent of legally proving that custody remained intact and that tampering or substitutions were precluded.

Coefficient of variation (CV): The standard deviation as a percent of the arithmetic mean.

Comparability: The degree of confidence with which one set of data can be compared to a related set of data.

Completeness: A measure of the amount of valid data obtained from a measurement system relative to the amount that was expected to be obtained under current, normal conditions.

Comprehensive Environmental Response, Compensation, and Liability Act (CERCLA): A federal law passed in 1980 and periodically modified by the Superfund Amendments and Reauthorization Acts passed by the U.S. Congress. The acts created a special tax that goes into a trust fund, commonly known as Superfund, to investigate and clean up abandoned or uncontrolled hazardous waste sites. Under the program, the EPA has the following options:

- pay for the site cleanup when parties responsible for the contamination cannot be located or are unwilling or unable to perform the work

- take legal action to force parties responsible for site contamination to clean up the site or repay the federal government for the cost of the cleanup

Concentration: The relative fraction of one substance in another, normally expressed in weight percent, in volume percent, as a weight per volume ratio, or as a weight per weight ratio.

Confidence limits: The limits within which, at some specified level of probability, the true value of a result lies.

Confined aquifer: An aquifer bounded above and below by impermeable beds or by beds of distinctly lower permeability than the aquifer itself. Also, an aquifer containing confined groundwater.

Congener: Any one particular member of a class of chemical substances. A specific congener is denoted by a unique chemical structure e.g., 2,3,7,8-tetrachlorodibenzofuran.

Contaminant: A chemical or biological substance that is harmful if it is incorporated into, onto, or ingested by organisms, consumers of organisms, or users of the environment.

Continuing calibration blank (CCB): A blank analyzed periodically during an analytical run to detect carryover contamination.

Continuing calibration verification (CCV): The periodic analysis of one or more standards during an analytical run to verify that the initial calibration continues to be valid. 
Contract-required quantitation limit (CRQL): The lowest required concentration of an analyte the laboratory may report for a specific contract. The contract-required quantitation limit is usually greater than the method detection limit.

Control limits: A range within which specified measurement results must fall to be compliant. Control limits may be mandatory, requiring corrective action if exceeded, or advisory, requiring that noncompliant data be flagged.

Correlation coefficient (r): A numeric value ( $r$ ) that indicates the degree of dependence between two variables (concentration vs. response). The more dependent they are, the closer the value is to one. The correlation coefficient is determined on the basis of the least squares function.

Custody: Immediate charge, control, or possession exercised by a competent authority on a sample.

Data quality objectives: The objectives for precision, accuracy, representativeness, completeness, comparability, and detection levels that are required to support the intended use of the data.

Definitive data: Data for which the accuracy of the concentration level and the identity of the analyte of interest are assessed. Definitive data are determined for samples considered essential in the decision-making process.

Deionized (DI) water: Water from which all charged species or ionizable organic and inorganic salts are removed by means of ion exchange.

Detection: The act of measuring the quantity of a property, compound, or element contained in a sample.

Dilution factor: The mathematical factor by which a sample is diluted to bring the concentration of an analyte in the sample within the analytical range of the instrument (e.g., $1 \mathrm{~mL}$ of sample $+9 \mathrm{~mL}$ of solvent $=1: 10$ dilution, or a dilution factor of 10 ).

Dry weight: The weight of a sample based on percent solids or the weight after drying in an oven for a specified time period at a specified temperature.

Electronic data deliverable (EDD): The summary of analytical results on machinereadable media received from a laboratory.

Estimated quantitation limit (EQL): The minimum concentration of a substance that can be reliably measured and reported within specified limits of precision and accuracy during routine laboratory operating conditions.

Field blank: See Blank.

Field duplicate: A second sample taken at the same time as the primary sample and sent to the laboratory for analysis as an unknown. The field duplicate is used to determine the precision of the entire sampling and analytical process.

Field sample: The material received at the laboratory to be analyzed that is contained in single or multiple containers and identified by a unique WSRC sample identification number.

Data Summary Report for the Annual Fourmile Branch and

F- and H-Area Seeplines, Appendix IX Metals and Radionuclides, 1998

(WSRC-TR-98-00260) 
Frequency: The specified intervals between samples in which quality control samples or standards must be analyzed during an analytical run.

Groundwater: Water in a saturated zone or stratum beneath the surface of land.

Half-life: The time required for one-half of the initial number of radioactive nuclei of a specific isotopic species to undergo radioactive decay.

Holding time: The maximum amount of time allowed for samples to be held from sample collection to laboratory analysis.

Independent standard: A laboratory-prepared standard solution that is composed of analytes from a different source than those used in the standards for the initial calibration.

Initial calibration: The analysis of standards containing varying concentration levels of the analytes of interest in order to establish the ratio of concentration vs. response across the working range of the analytical technique. The initial calibration is used to define the linearity and dynamic range of response of the detector to the target analytes.

Initial calibration blank (ICB): A blank analyzed immediately after the initial calibration verification but before the analytical run to detect carryover contamination.

Initial calibration verification (ICV): The analysis of one or more standards immediately after the initial calibration but before the analytical run to verify that the initial calibration was valid.

Instrument detection limit (IDL): The minimum concentration of an analyte that can be measured and reported with $99 \%$ confidence that the analyte concentration is greater than zero. It is determined from analysis of a deionized water blank containing the analyte.

Interference check sample (ICS): Two solutions, one consisting of interferents only (ICSA) and one consisting of interferents mixed with the analytes (ICSAB), that are analyzed consecutively to verify the interelement and background correction factors for inductively coupled plasma metal analyses.

Interferents: Substances that affect the analysis for the element of interest.

Interlaboratory comparison: The comparison of results from split samples analyzed by two laboratories.

Internal standard: A chemically inert compound not expected to occur in an environmental sample that is added to a sample prior to analysis; it is used as an instrument response check.

Intralaboratory comparison: The comparison of duplicate results from a single sample analyzed by a laboratory.

Isomer: One of two or more chemical substances having the same elementary percentage composition and molecular weight but differing in structure and properties. 
Isotope: One of a number of specific atoms with identical atomic numbers but with discrete atomic weights, or similarly specific atoms whose nuclei have the same number of protons but different numbers of neutrons.

Laboratory control sample (LCS): A control sample of known composition. Aqueous and solid laboratory control samples are analyzed using the same sample preparation, reagents, and analytical methods employed for the samples received.

Laboratory data records review (LDRR): The investigation of technical data validation issues that are not adequately addressed by the computer checking of EDDs, the review of the analytical narratives, and the review of the $\mathrm{COC}$ forms. The review is conducted at the laboratory using the laboratory's instrument logs, raw analytical data, and other pertinent documentation.

Laboratory duplicate: A second aliquot of a homogenized sample that is analyzed as an individual sample, using the same procedure. This duplicate is used to determine the precision of the method.

Laboratory ID: The identifier assigned by the laboratory for its internal use during the analytical process.

Linear range, linear dynamic range: The concentration range over which the calibration curve remains linear.

Lowest practical quantitation limit (LPQL): The lowest concentration of an analyte that can be reliably achieved within specified limits of precision and accuracy during routine laboratory operating conditions.

Matrix: The predominant material of which the sample to be analyzed is composed. For the purpose of this document, a sample matrix is either water or soil/sediment.

Matrix interference: The influence of the sample matrix or sample components upon the ability to quantitatively measure compounds in environmental samples.

Matrix spike/matrix spike duplicate: A first and second aliquot of a matrix fortified (spiked) with a known quantity of analyte(s) and subjected to the entire analytical procedure in order to determine the appropriateness of the method for the matrix by measuring accuracy (recovery) and precision (relative percent difference).

Maximum contaminant level (MCL): The maximum permissible level of a contaminant in a specified medium.

Mean relative difference (MRD): The average of the absolute difference of the results from two laboratories for the $i^{\text {th }}$ sample that is expressed as a percentage of the mean of both laboratories.

\section{Method blank: See Blank.}

Method detection limit (MDL): The minimum concentration of an analyte that can be measured and reported with $99 \%$ confidence that the analyte concentration is greater than zero. It is determined from analysis of a sample in a given matrix containing the analyte. 
Minimum detectable activity (MDA): The smallest quantity of a radionuclide that can be detected in a sample with a $95 \%$ confidence level.

Nuclide: General term applied to all isotopes of all elements including stable and radioactive forms. Nuclides are not considered isotopes; rather, a given nuclide is characterized by the number of neutrons and protons contained in the atomic nuclei of that species.

Null hypothesis: A statement that can be tested statistically to determine if there is a significant difference between duplicate/split results.

Parts per billion ( $\mathrm{ppb}$ )/Parts per million ( $\mathrm{ppm}$ ): Units commonly used to express low concentrations of contaminants. For example, 5 micrograms of benzene in 1 kilogram of soil is $5 \mathrm{ppb} ; 3$ milligrams of nitrate in 1 liter of water is $3 \mathrm{ppm}$.

Percent moisture: An approximation of the amount of water in a soil/sediment sample determined by drying an aliquot of sample at a specified temperature until constant weight is achieved.

Percent recovery: A measure of recovery that is calculated as the measured value relative to the true value, expressed as a percent.

Percent solids: The proportion of solid in a soil/sediment sample determined by the percent moisture procedure.

Performance evaluation sample: A sample of known composition that may be provided by the EPA or WSRC for laboratory analysis that is used to evaluate laboratory performance.

PicoCurie (pCi): The unit of radiation equivalent to $3.7 \times 10^{-2}$ disintegrations per second.

Precision: The agreement or repeatability of a set of replicate results among themselves, usually expressed in terms of the deviation of a set of results from the arithmetic mean. Precision may be qualified in terms of possible sources of variability, replicability, repeatability, and reproducibility.

Preparation log: An official record of the sample preparation.

Preservative: A chemical compound added to a sample or a physical process (such as cooling) to prevent or slow decomposition or degradation of a target analyte. Physical and chemical preservation may be used in tandem to prevent sample deterioration.

Primary laboratory: The laboratory having a contract with WSRC to perform a specific set of analyses for field-generated samples, duplicates, and blanks. A primary laboratory may subcontract this work to other laboratories.

Qualifier: A code used to convey additional information about an analytical result. See the following examples.

- A Result Qualifier is used to indicate the usability of the result for regulatory purposes.

Data Summary Report for the Annual Fourmile Branch and

F- and H-Area Seeplines, Appendix IX Metals and Radionuclides, 1998

(WSRC-TR-98-00260) 
- An Analysis Qualifier is used to describes analytical conditions which apply to the datum. Analysis qualifiers are included for information only.

- A Bias Qualifier is a code used to indicate whether a result may overestimate or underestimate the true value. It also may be used to indicate poor precision.

See Appendix $D$ for additional information and the specific qualifiers used.

Qualitative analysis: An analysis to determine the presence or absence of a target analyte.

Quality assurance plan: The documented data quality objectives and the actions to be performed to meet those objectives.

Quality control (QC): The performance of actions that provide a way to control and measure the characteristics of measurement equipment and processes to meet the established data quality objectives.

Quantitative analysis: An analysis to measure or determine the amount of a target compound or analyte within the limits of defined precision and accuracy requirements.

Radionuclide: Any radioactive isotope of an element.

Range: The difference between the maximum and minimum values within a set of values.

RCRA Facility Investigation/Remedial Investigation (RFI/RI) program: The EPA. regulated investigation of a solid-waste management site, including CERCLA and hazardous-substance regulations, with regard to its potential impact on the environment.

Recovery: A determination of accuracy of the analytical procedure made by comparing measured values for a reference or fortified (spiked) sample against the known true reference or spike values.

Reference detection limit (RDL): The detection limit chosen to allow comparison of multiple analyses with different detection limits. For this report, the individual detection limits of at least $90 \%$ of the analyses are less than the reference detection limit.

Relative percent difference (RPD): A measure of precision that is calculated as the absolute value of the difference between two results, relative to their arithmetic mean, expressed as a percent.

Reporting limit: The value reported in the result field when an analyte is not detected.

Reproducibility: The precision of measurements of the same sample at different laboratories using the same protocols.

Resolution: The degree to which two signal peaks are separated. Resolution is calculated by dividing the height of the valley between the peaks by the height of the peak being resolved, multiplied by 100 .

Resource Conservation and Recovery Act (RCRA): A 1976 federal law that established a regulatory system to define and track hazardous wastes from the time of generation to disposal. The law requires safe and secure procedures to be used in treating, transporting, storing, and disposing of hazardous substances.

Data Summary Report for the Annual Fourmile Branch and

F- and H-Area Seeplines, Appendix IX Metals and Radionuclides, 1998

(WSRC-TR-98-00260) 
Rinsate blank: See Blank.

Run: A continuous analytical sequence consisting of prepared samples and all associated quality control measurements.

Sample: A portion of material to be analyzed that is contained in single or multiple containers and identified by a unique sample number.

Sample ID: A unique identification number designated by WSRC for each sample. The WSRC sample ID appears on the sample chain of custody that documents information on that sample.

Sample matrix: All of the chemical components and physical characteristics of a sample other than the parameter of interest.

Sample-specific estimated quantitation limit (ssEQL): The estimated quantitation limit multiplied by factors of concentration, dilution, aliquot size, and percent solids.

Sediment: The unconsolidated inorganic and organic material that is suspended in and being transported by surface water or that has settled out and has deposited into beds.

Self-absorption: The internal absorption of radiation by material in which radioactive atoms are located.

Sensitivity: The ability of a measurement system to detect and accurately quantitate a parameter at a critical level within a specific sample matrix. The critical level may be a regulatory maximum contaminant level (MCL), MDA, or risk-based exposure level.

Significance of probability: The probability of observing a statistical value as significant as, or even more significant than, the value actually observed.

Soil: All unconsolidated materials normally found on or near the surface of the earth including, but not limited to, silts, clays, sands, gravel, and small rocks.

Solvent: Liquid that is capable of dissolving another substance.

Split sample: A second aliquot of a sample, generated in the field, that is sent to a secondary laboratory for analysis; a split sample serves as a quality control check.

Standard deviation: The measurement of dispersion about a mean value of a series of observations expressed in the same units as the mean value.

Surface water: All water that is open to the atmosphere and subject to surface runoff.

Surrogate: A chemically inert organic compound similar in composition and test performance to an analyte of interest added to samples prior to analysis as a quality control check.

Surrogate recovery: A quality control measurement to monitor unusual matrix effects, gross sample processing errors, etc. It is evaluated for acceptance by determining whether the measured concentration falls within the statistical acceptance limits established by the laboratory. 
Target analyte list (TAL): The list of inorganic analytes required by CERCLA.

Target compound list (TCL): The list of organic analytes required by CERCLA.

Technical holding time: The storage time allowed between sample collection and sample analysis when designated preservation and storage techniques are employed. This is determined by the elapsed time in days from the date and time of collection to the date and time of sample preparation and analysis.

- Technical holding time $=$ (sample analysis date and time - sample collection date and time).

Tentatively identified compound (TIC): Chromatographic peak in volatile and semivolatile fraction analysis that is not a target analyte, surrogate, or internal standard.

Time: When required to record time on any deliverable item, time is expressed as military time, i.e., on a 24 -hour clock.

Toxicity characteristic leaching procedure (TCLP): An analytical extraction procedure used to determine the mobility of both inorganic and organic analytes present in solid, liquid, and multiphasic wastes.

Tracer: A quantity of a unique radioisotope of the same element added to a sample, chemically prepared, or separated and counted. The quantity of tracer measured is compared to the quantity of target radioactive element measured, and the target quantity is calculated on the basis of unity with the tracer concentration.

Trip blank: See Blank.

Wet weight: The weight of a sample aliquot including moisture (undried). 